\title{
DALTON HIGHWAY FIELD TRIP GUIDE FOR THE NINTH INTERNATIONAL CONFERENCE ON PERMAFROST
}

A supplement to Guidebook 4, "Guidebook to permafrost and related features along the Elliott and Dalton Highways, Fox to Prudhoe Bay, Alaska," 1983, by Jerry Brown and R.A. Kreig, editors, published by the Alaska Division of Geological \& Geophysical Surveys for the Fourth International Conference on Permafrost.

by D.A. Walker, T.D. Hamilton, C.L. Ping, R.P. Daanen, and W.W. Streever

With contributions by M.S. Bret-Harte, R.R. Gieck, T.N. Hollingsworth, L.S. Jodwallis, D.L. Kane, G.J. Michaelson, F.E. Nelson, C.A. Munger, M.K. Raynolds, V.E. Romanovsky, G.R. Shaver, E.M. Barbour, C.A. Stiles

Guidebook 9

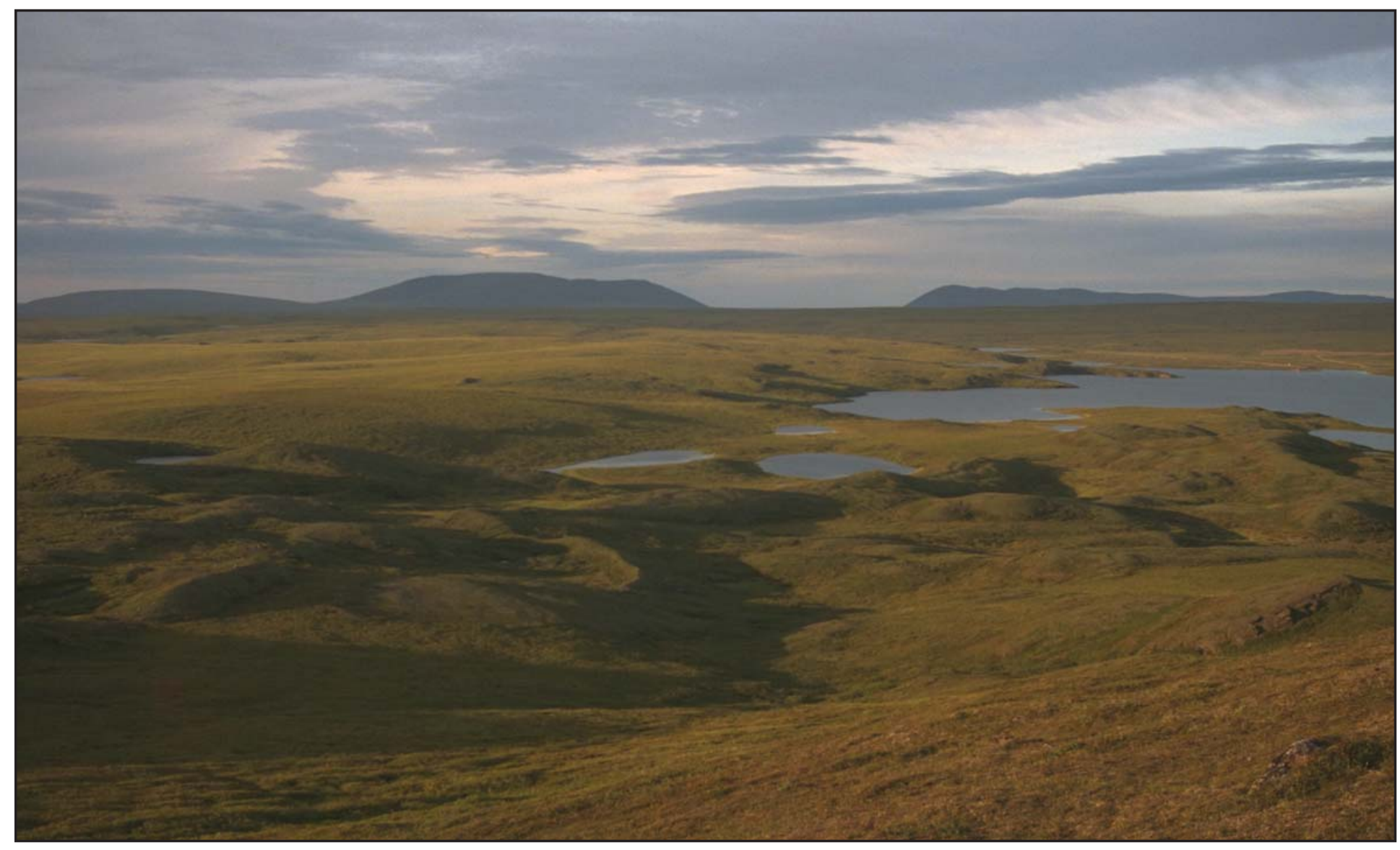

Published by

STATE OF ALASKA 



\title{
DALTON HIGHWAY FIELD TRIP GUIDE \\ FOR THE NINTH INTERNATIONAL \\ CONFERENCE ON PERMAFROST
}

A supplement to Guidebook 4, "Guidebook to permafrost and related features along the Elliott and Dalton Highways, Fox to Prudhoe Bay, Alaska," 1983, by Jerry Brown and R.A. Kreig, editors, published by the Alaska Division of Geological \& Geophysical Surveys for the Fourth International Conference on Permafrost.

by D.A. Walker, T.D. Hamilton, C.L. Ping, R.P. Daanen, and W.W. Streever

With contributions by M.S. Bret-Harte, University of Alaska Fairbanks; R.R. Gieck, University of Alaska Fairbanks; T.N. Hollingsworth, U.S. Forest Service, Bonanza Creek Research Unit; L.S. Jodwallis, Bureau of Land Management; D.L. Kane, University of Alaska Fairbanks; G.J. Michaelson, University of Alaska Fairbanks; F.E. Nelson, University of Delaware; C.A. Munger, University of Alaska Fairbanks; M.K. Raynolds, University of Alaska Fairbanks; V.E. Romanovsky, University of Alaska Fairbanks; G.R. Shaver, Ecosystems Center, Marine Biological Laboratory; C.A. Stiles, National Soil Survey Laboratory-Natural Resources Conservation Service, U.S. Department of Agriculture; K. Yoshikawa, University of Alaska Fairbanks; E.M. Barbour, University of Alaska Fairbanks

\section{Division of Geological \& Geophysical Surveys}

\section{Guidebook 9}

\author{
Prepared for \\ Ninth International Conference on Permafrost \\ June 29 - July 3, 2008 \\ University of Alaska Fairbanks \\ D.A. “Skip” Walker, Trip Leader
}

Cover photo: View from Jade Mountain looking northeast to Imnavait Mountain, of the Itkillik II surfaces surrounding Toolik Lake. Photo by D.A. Walker. 



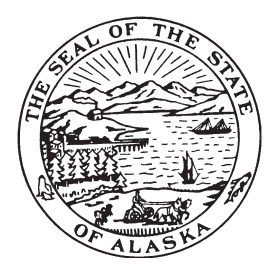

STATE OF ALASKA

Sarah Palin, Governor

DEPARTMENT OF NATURAL RESOURCES

Tom Irwin, Commissioner

\section{DIVISION OF GEOLOGICAL \& GEOPHYSICAL SURVEYS Robert F. Swenson, State Geologist and Director}

Publications produced by the Division of Geological \& Geophysical Surveys can be examined at the following locations. To order publications, contact the Fairbanks office.

\author{
Alaska Division of Geological \& \\ \& Geophysical Surveys \\ 3354 College Road \\ Fairbanks, Alaska 99709-3707 \\ Elmer E. Rasmuson Library \\ University of Alaska Fairbanks \\ Fairbanks, Alaska 99775-1005
}

\author{
Alaska Resource Library \& Information \\ Services (ARLIS) \\ 3150 C Street, Suite 100 \\ Anchorage, Alaska 99503 \\ University of Alaska Anchorage Library \\ 3211 Providence Drive \\ Anchorage, Alaska 99508
}

\begin{abstract}
Alaska State Library
State Office Building, 8th Floor

333 Willoughby Avenue

Juneau, Alaska 99811-0571
\end{abstract}

This publication released by the Division of Geological \& Geophysical Surveys was produced and printed in Fairbanks, Alaska, at a cost of $\$ 15$ per copy. Publication is authorized by Alaska Statute 41, which charges the division "to determine the potential of Alaskan land for production of metals, minerals, fuels, and geothermal resources; the location and supplies of groundwater and construction materials; the potential geologic hazards to buildings, roads, bridges, and other installations and structures; and shall conduct such other surveys and investigations as will advance knowledge of the geology of Alaska." 



\section{CONTENTS}

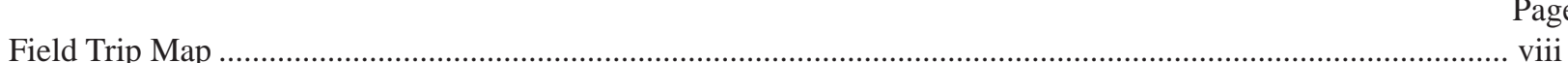

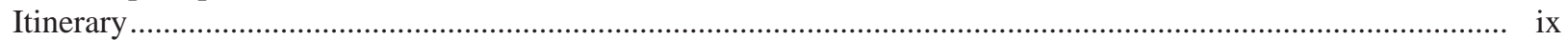

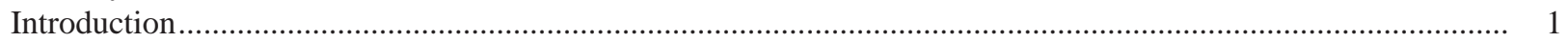

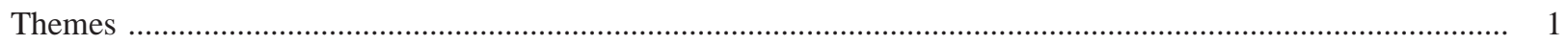

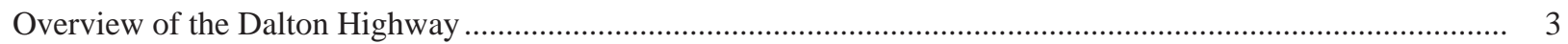

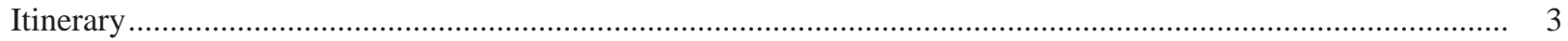

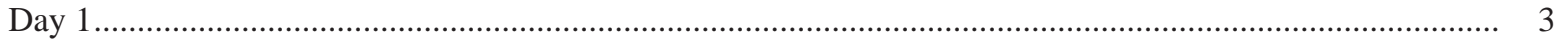

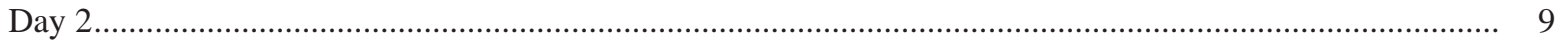

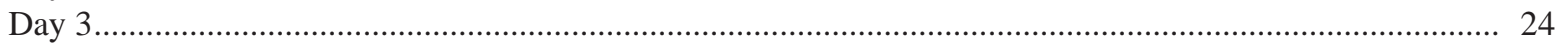

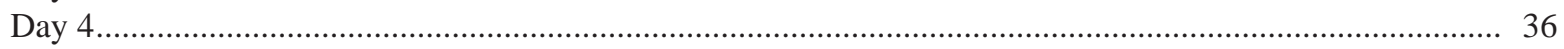

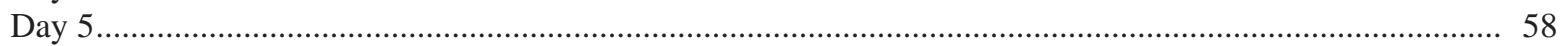

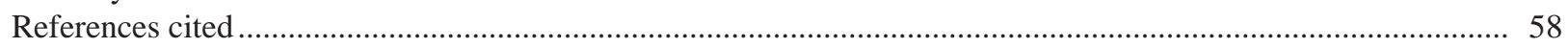

Appendix A. The essentials of Alaskan geology and geomorphology: Bedrock and glacial geology of

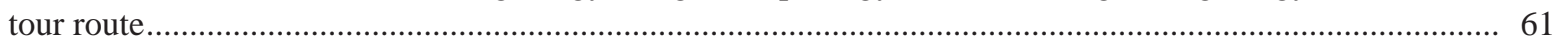

Appendix B. Soils of Alaska along the 2008 NICOP field excursion..................................................................... 67

Appendix C. Stop 31, Happy Valley: Active-layer studies, and the CALM network.............................................. 73

Appendix D. Annotated agenda for the North Slope oil fields tour as part of the Permafrost Conference ............... 77

Appendix E. Permafrost temperatures of the North Slope and flow slides in the Brooks Range..............................101

Appendix F. Debris slides or rock glaciers south side of Brooks Range ................................................................ 104

\section{FIGURES}

Figure 1. Graph showing climate-biotic system-permafrost interactions ..................................................... 1

2. Graph showing climate gradient along the Dalton Highway .............................................................. 2

3. $\quad$ Map showing route of the Dalton Highway Field Trip .......................................................................... 3

4. Photos showing leaf miner moth on newly opened bud and leaf miner trails on quaking aspen leaf........................................................................................................................... 4

5. Photo showing pipeline transition between buried and elevated mode .............................................. 5

6. Photos showing fire on Gobbler's Knob, June 2005, and fireweed display following the fires .......... 7

7. Photo showing tor at the Finger Mountain overlook ...................................................................... 8

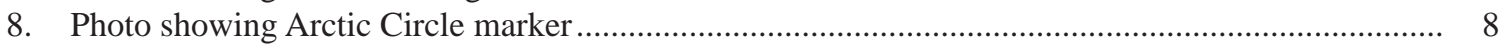

9. Photos showing multi-agency Visitor Center at Coldfoot..................................................................... 9

10. Photo showing Sukakpak Mountain viewed from the Dietrich River Bridge .................................... 10

11. Photo showing farthest north spruce tree along the Dalton Highway in 2001 before the tree was

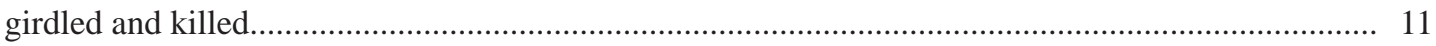

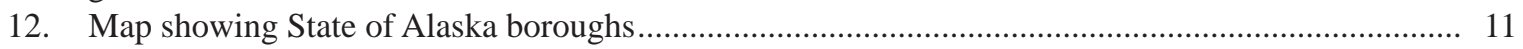

13. Photo showing pingo-like feature near Chandalar Camp ........................................................... 12

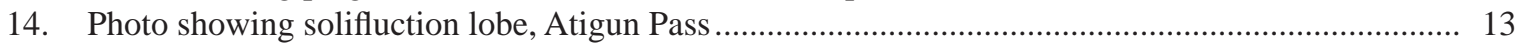

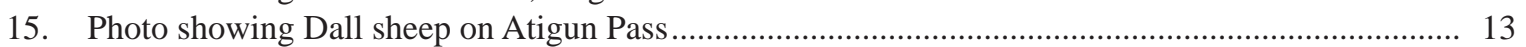

16. Photo showing ancient hunting blind near Atigun Pass ................................................................... 14

17. Photo showing alpine cirque at the summit of Atigun Pass ................................................................. 14

18. Photo showing alpine wetland with sorted circles near the summit of Atigun Pass ............................ 15

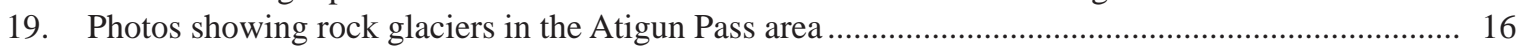

20. Photo showing lobate-shaped rock glacier at Atigun Pass................................................................. 17

21. Photos showing steep, large alluvial fan on the east side of the road near the old Atigun

Construction Camp and semi-steep compound fan (alluvial, colluvial, alpine) built by mass

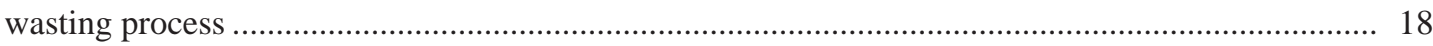

22. Photos showing nonsorted circles at Galbraith Lake and Galbraith Lake soil study site .................... 19

23. Photo and drawing showing soil profile for nonsorted circle at Galbraith Lake ............................... 20

24. Photos showing aufeis deposit at Galbraith Lake ........................................................................ 23

25. Photo showing Sagavanirktok-age surface at Imnavait Creek......................................................... 25

26. Graph showing an example of long-term observed trends in active-layer depth, air temperature, soil temperature, and snow depth near Franklin Bluffs, from 1987 to 2007...................................... 25 

27. Graph showing long-term permafrost temperatures for sites on Alaska's North Slope........................ 26

28. Photo showing Itkillik II glacial surface viewed from Jade Mountain .............................................. 26

29. Photo showing Imnavait Creek watershed and Toolik River headwaters ............................................ 27

30. Location map of four nested watersheds being studied on the North Slope of Alaska....................... 28

31. Graph showing hypsometric curves of four nested watersheds on the North Slope of Alaska with elevations of meteorological sites indicated ...................................................................................... 29

32. Graph showing 23-year time window of snow ablation at Imnavait Creek, North Slope, Alaska ...... 30

33. Graph showing flow frequency curves for Imnavait Creek illustrating snowmelt and rainfall

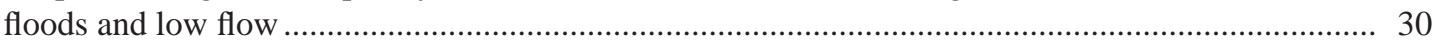

34. Graph showing flow frequency curves for the upper Kuparuk River basin illustrating snowmelt and rainfall floods and low flow.................................................................................................. 31

35. Graph showing flow frequency curves for the entire Kuparuk River basin, illustrating snowmelt

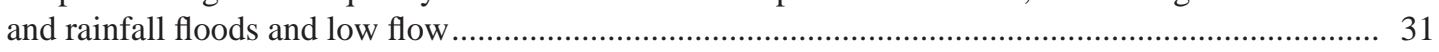

36. Photo showing boulder-littered surface of Itkillik II age at Toolik Lake............................................ 32

37. Photo showing rainfall exclusion experimental plot on the north side of Toolik Lake ....................... 33

38. Photos showing ice exposed in mound at base of hill at Slope Mountain .......................................... 37

39. Photos showing revegetated buried pipeline berm and gasline trench near MP 308 ......................... 38

40. Photo showing Happy Valley road cut ........................................................................................... 39

41. Photos showing typical landforms in the Northern Foothills Physiographic Province ....................... 40

42. Photos showing patterned ground forms along the Arctic bioclimate gradient ................................... 41

43. Photos showing monitoring grid for biocomplexity of patterned ground study at Happy Valley and device for monitoring soil heave at Deadhorse site ........................................................................ 42

44. Map showing study locations within the five Arctic bioclimate subzones ........................................ 43

45. Graph showing trends in temperature, active layer, frost heave, biomass, and thickness of vegetation, moss, soil organic layer, and snow along the North American Arctic Transect on and between patterned-ground features ........................................................................................... 44

46. Graphs showing mean summer and winter $\mathrm{n}$-factors at representative sites in each subzone along the North American Arctic Transect and summer n-factor vs. thickness of the green moss layer and winter n-factor vs. snow depth measured in May 2006 ...

47. Graphs showing dominant genetic processes and patterns involved in patterned-ground formation on zonal sites along the Arctic bioclimate gradient.............................................................. 47

48. Photo showing Wyoming snow gauge and climate monitoring site at Sagwon................................... 47

49. Photo showing MNT/MAT boundary on Landsat image of Sagwon area .......................................... 48

50. Photos showing moist acidic tundra and moist nonacidic tundra at Sagwon $\mathrm{pH}$ boundary ................ 49

51. Photos and soil horizon diagrams showing soils associated with moist acidic tundra and moist nonacidic tundra, Sagwon ....................................................................................................... 50

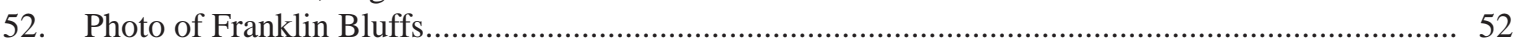

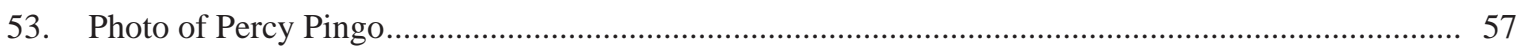

54. Photo of eroded troughs of low-centered polygons near Deadhorse ................................................... 57

\section{TABLES}

Table 1. Galbraith Lake nonsorted circle pedon description ....................................................................... 21

2. Galbraith Lake nonsorted-circle site soil chemical and physical properties....................................... 22

3. List of terrestrial research experiments for the Arctic Long Term Ecological Research (LTER) Project

4. Selected characteristics of moraine sequences of Itkillik age in northern and southern valleys of the central Brooks Range.

5. Comparison of properties of Moist Nonacidic Tundra (MNT) vs. Moist Acidic Tundra (MAT) sites at Sagwon ........................................................................................................................ 51

6. Comparison of ecosystem properties of Moist Nonacidic Tundra (MNT) and Moist Acidic Tundra (MAT) at flux tower sites 3 and 4 and other sites in the Kuparuk River Basin ....................... 52

7. Soil profile for Ruptic-Histic Aquiturbel, Moist Acidic Tundra pedon description.............................. 53

8. Ruptic-Histic Aquiturbel (Turbic Histic Cryosol), Moist Nonacidic pedon description...................... 54

9. Selected soil chemical and physical properties for Moist Nonacidic Tundra (MNT) and Moist Acidic Tundra (MAT), Sagwon. 


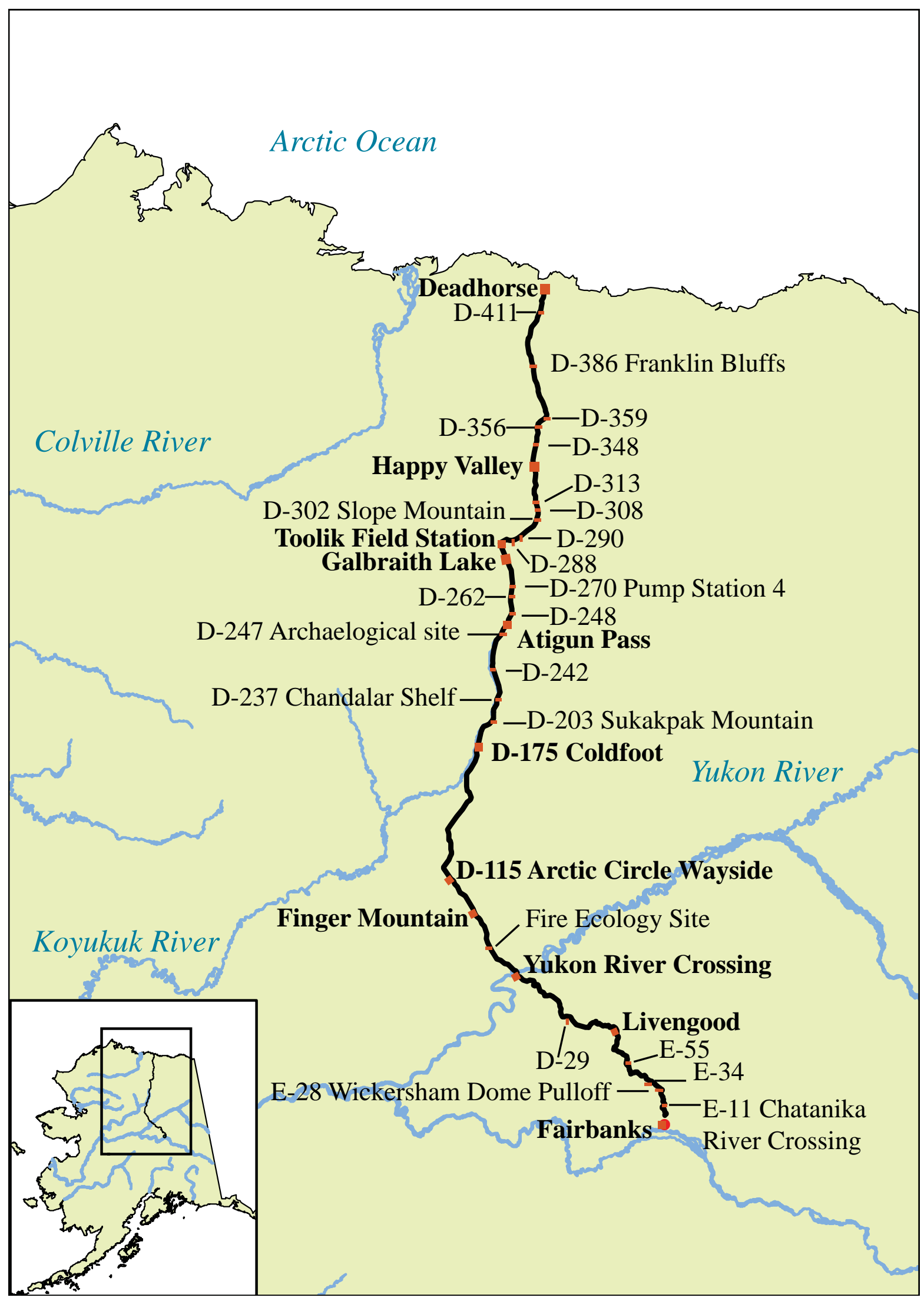




\section{ITINERARY}

DAY 1

Stop 1: Milepost E-34, Buried and elevated pipelines at ecosystem-permafrost transition..................................... 4

Stop 2: Milepost E-39, Good views of north- and south-facing hill slopes.............................................................

Stop 3: Milepost E-57, Tolovana River bridge, Colorado Creek trailhead, black spruce forest.............................. 5

Stop 4: Milepost E-70, Livengood turnoff...................................................................................................... 6

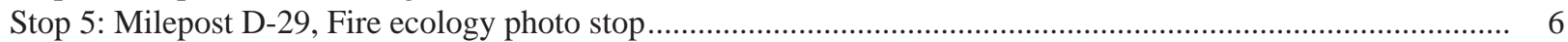

Stop 6: Milepost D-56, Yukon River and E.L Patton bridge.............................................................................. 6

Stop 7: Milepost, D-85.7, Fire ecology research, U.S. Forest Service ................................................................ 6

Stop 8: Milepost D-98, Finger Mountain..................................................................................................... 7

Stop 9: Milepost D-115, Arctic Circle ………........................................................................................... 8

Stop 10: Milepost D-175, Coldfoot Camp ............................................................................................. 8

DAY 2

Stop 11: Milepost D-204, Sukakpak Mountain ................................................................................................ 9

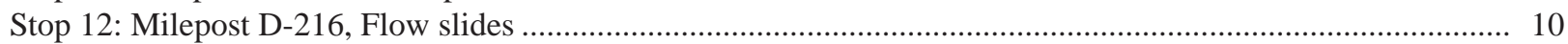

Stop 13: Milepost D-242, Pingo-like feature near Chandalar Camp ........................................................... 10

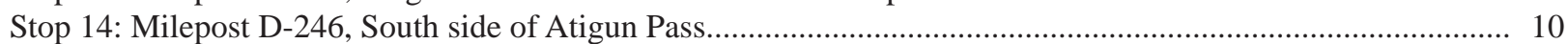

Stop 15: Milepost D-247, Summit of Atigun Pass (1,447 m; 4,747.4ft), Continental Divide............................... 13

Stop 16: Milepost D-248, North side of Atigun Pass.................................................................................... 15

Stop 17: Milepost D-262, Atigun River valley ................................................................................................ 17

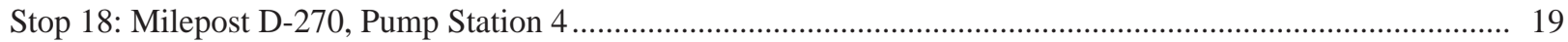

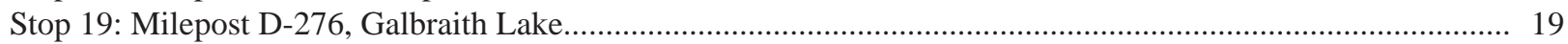

Stop 20: Milepost D-286, Toolik field station.................................................................................................... 22

\section{DAY 3}

Stop 21: Milepost D-288, Overlook of Itkillik glacial surfaces.............................................................................. 24

Stop 22: Entrance to Material Site 117, weather station for permafrost observatory network ................................ 25

Stop 23: Material Site 117, Imnavait Creek research site................................................................................ 25

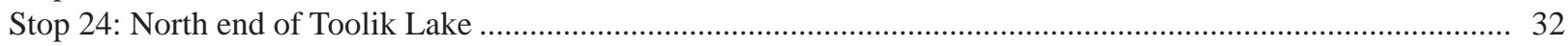

Stop 25: Milepost D-298, Itkillik I/II glacial boundary overlooking the Sagavanirktok River............................... 34

\section{DAY 4}

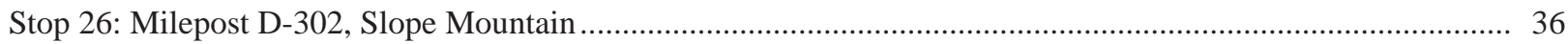

Stop 27: Milepost D-308, Pipeline and construction pad revegetation ............................................................. 37

Stop 28: Milepost D-325, Uplands south of Happy Valley............................................................................. 39

Stop 29: Milepost D-336, Happy Valley camp and research site....................................................................... 39

Stop 30: Milepost D-348, Sagavanirktok River icing.......................................................................................... 43

Stop 31: Milepost D-356, Sagwon climate station and biocomplexity research site................................................ 43

Stop 32: Milepost D-359, Acidic/nonacidic tundra boundary ...................................................................... 46

Stop 33: Milepost D-386, Franklin Bluffs …………................................................................................... 50

Stop 34: Milepost D-410.8, Coastal plain features ............................................................................................ 57

Stop 35: Milepost D-413.5, Eroded low-centered polygons at Deadhorse......................................................... 57

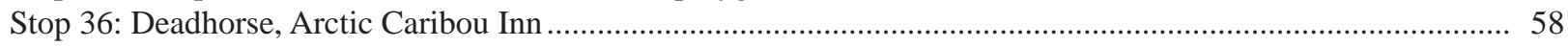

DAY 5

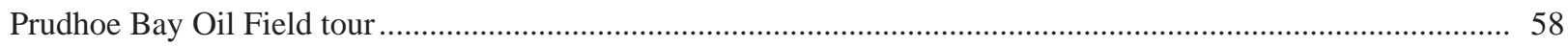





\section{DALTON HIGHWAY FIELD TRIP GUIDE FOR THE NINTH INTERNATIONAL CONFERENCE ON PERMAFROST}

A supplement to Guidebook 4, "Guidebook to permafrost and related features along the Elliott and Dalton Highways, Fox to Prudhoe Bay, Alaska," 1983, by Jerry Brown and R.A. Kreig, editors, published by the Alaska Division of Geological \& Geophysical Surveys for the Fourth International Conference on Permafrost.

D.A. Walker, ${ }^{1}$ T.D. Hamilton, ${ }^{2}$ C.L. Ping, ${ }^{3}$ R.P. Daanen, ${ }^{4}$ and W.W. Streever ${ }^{5}$

With contributions by M.S. Bret-Harte, R.R. Gieck, T.N. Hollingsworth, L.S. Jodwallis, D.L. Kane, G.J. Michaelson, F.E. Nelson, C.A. Munger, M.K. Raynolds, V.E. Romanovsky, G.R. Shaver, C.A. Stiles, K. Yoshikawa, E.M. Barbour

\section{INTRODUCTION}

This guidebook was created for a 5-day field trip that traversed the Elliott and Dalton highways from Fairbanks to Prudhoe Bay, Alaska, June 23-27, 2008, as part of the Ninth International Conference on Permafrost (NICOP).

This guidebook is a supplement to the Elliott and Dalton Highways, Fox to Prudhoe Bay, Alaska guidebook created for the Fourth International Conference on Permafrost, held in Fairbanks in 1983 (Brown and Kreig, 1983), and reprinted for this field trip. It is still the most comprehensive guide to permafrost and related features along the route.

Before starting on the field trip, participants read the introduction to the Dalton Highway in Brown and Kreig (1983, p. 1-35), which surveys the history of the Elliott, Hickel, and Dalton highways, the Trans-Alaska Pipeline System, and the environmental features along the route. Most of the stops during the 2008 field trip had additional information from Brown and Kreig (1983).

This guidebook focuses on the stops that we made along the route. At some of these stops additional materials were handed out.

\section{THEMES}

A major theme of this trip is how permafrost affects arctic biotic systems and vice versa (fig. 1). Much current research focuses on the complex interactions that occur between climate, vegetation, soils, water, and the underlying permafrost. The vegetation mat and the organic soil horizons strongly affect soil thermal regimes, and can have major effects on a wide variety of permafrostrelated phenomena, including the depth of the active layer, distribution of permafrost, the development of ice-rich permafrost layers, buried carbon, and the nature of patterned-ground features. Each day of the trip will focus on aspects of the climate-ecosystem-permafrost interactions that are best illustrated in different parts of the Dalton Highway transect.

A second theme uses the climate gradient along the Dalton Highway to examine the effects of climate change on permafrost environments (fig. 2). The Dalton Highway traverses the northern portion of the Boreal Climate Zone, and the warmer and relatively well vegetated Low Arctic portion of the Arctic Bioclimate Zone. As we travel farther north, the elevation belts in alpine areas of the Brooks Range provide a glimpse of vegetation transitions similar to the more poorly vegetated High Arctic. The analog between elevation belts and latitudinal bioclimate subzones does not, however, extend to permafrost in the Brooks Range because mean annual

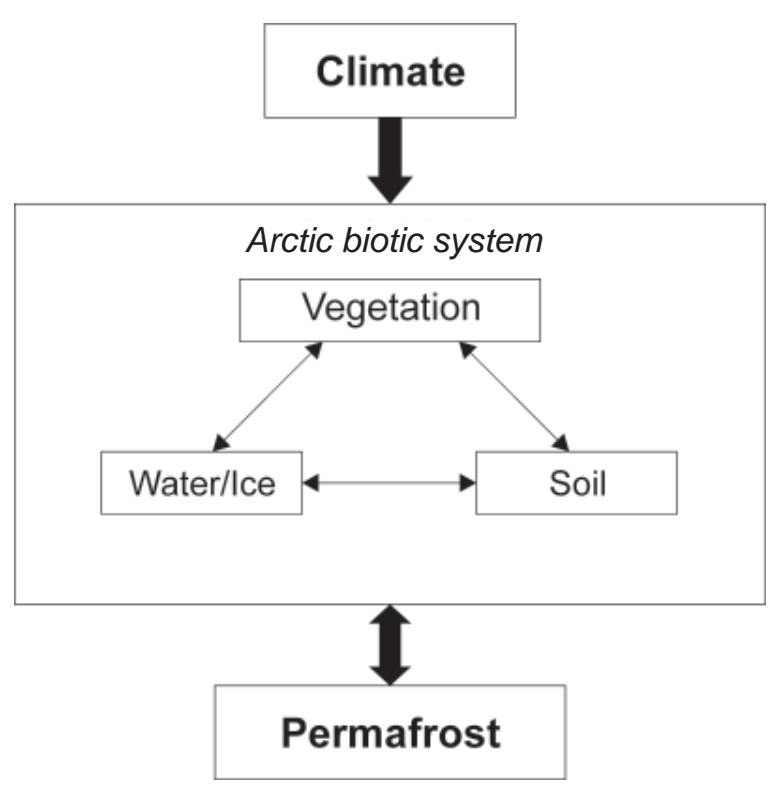

Figure 1. Climate-biotic system-permafrost interactions.

${ }^{1}$ Institute of Arctic Biology, 311 Irving Building, University of Alaska Fairbanks, Fairbanks, Alaska 99775; ffdaw@uaf.edu

${ }^{2}$ U.S. Geological Survey Emeritus, 4200 University Drive, Anchorage, Alaska 99508

${ }^{3}$ University of Alaska Fairbanks, P.O. Box 757320, Fairbanks, Alaska 99775-7320

${ }^{4}$ Palmer Research Center, University of Alaska Fairbanks, 533 E. Fireweed Avenue, Palmer, Alaska 99645

${ }^{5}$ BP Exploration (Alaska) Inc., P.O. Box 196612, Anchorage, Alaska 99519-6612 


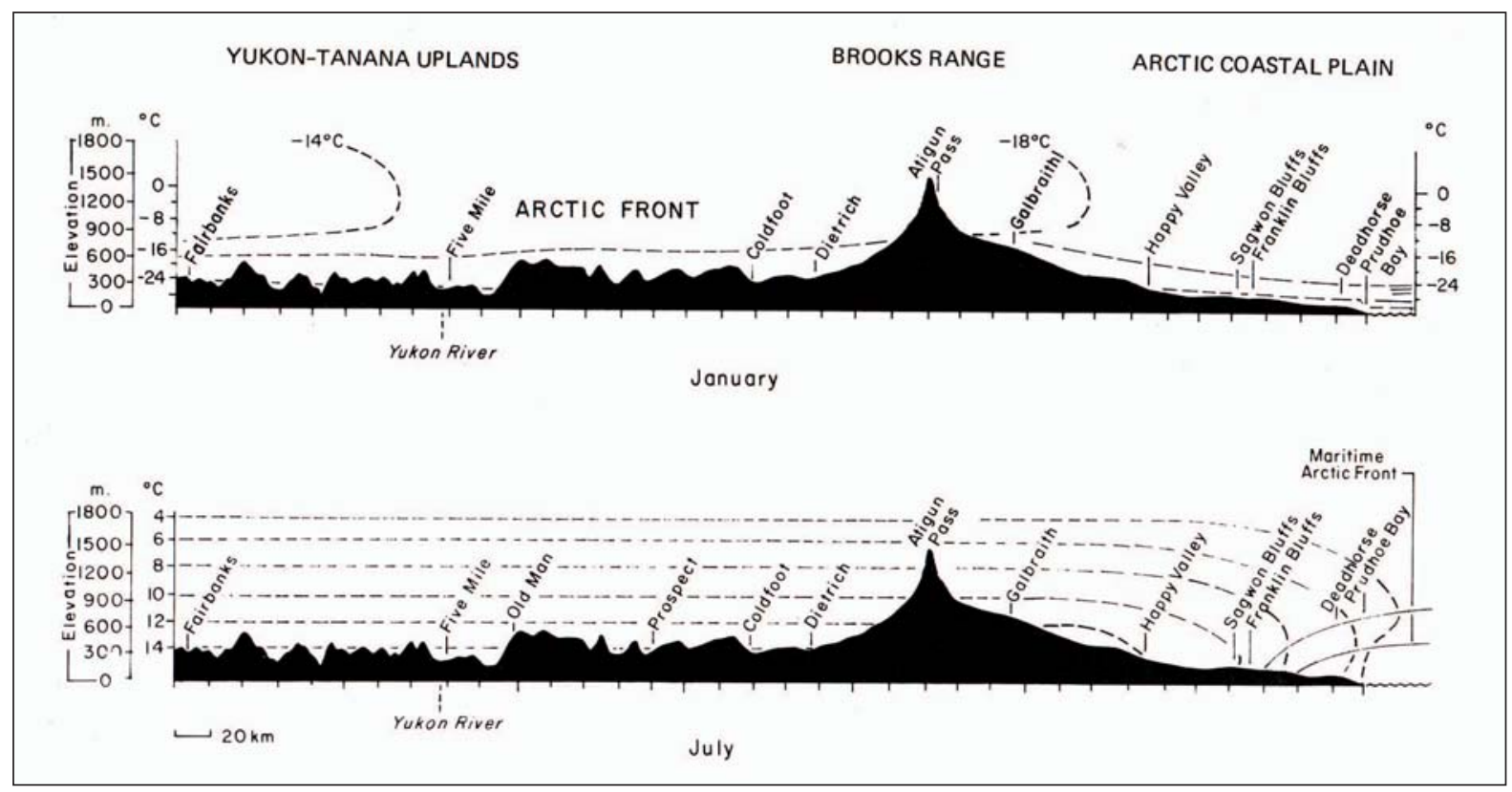

Figure 2. Climate gradient along the Dalton Highway. Three of the five circumpolar Arctic bioclimate subzones occur in northern Alaska, and the elevation belts in the Brooks Range provide summer climate analogs for the other two (Haugen, 1982).

temperatures are warmer and summer temperatures are cooler at high altitudes than they are in the comparable latitudinal bioclimate zones.

A third theme is how permafrost and arctic systems change through time. This theme will be addressed at two primary scales: the quick changes associated with vegetation succession following fire in the boreal forest, and the long-term changes associated with major glaciations on the Arctic North Slope. Alaska's first and third biggest fire years on record occurred in 2004 and 2005. Nearly 4.5 million hectares (more than 11 million acres) of forest burned during these two years and much of the Dalton Highway corridor was affected. Since then the Bonanza Creek Long-Term Ecological Research (LTER) project, the Bureau of Land Management (BLM), and the U.S. Forest Service (USFS) have been studying fire at several sites along the highway. We will see these research efforts, examine recovery since the fires, and listen to fire ecologists discuss the interactions between fire and permafrost. North of the Brooks Range, we will spend two days in landscapes that were glaciated during different intervals of the Pleistocene, see how landscape succession has varied on these differently aged surfaces, and the consequences to regional geomorphology, ecology, and permafrost.

A fourth theme is how humans are affecting permafrost environments. We will examine some of the human-induced changes occurring along the Dalton
Highway and the Alyeska Pipeline, and spend a day in the Prudhoe Bay oil field seeing how the oil industry is adapting its operations to permafrost environments.

The final theme addresses how research is being conducted in permafrost environments. We will visit numerous scientific research sites, including active fire-research sites in the boreal forest, the Long-Term Ecological Research sites at Toolik Lake and Imnavait Creek, the Permafrost Observatory Network, Circumpolar Active Layer Monitoring (CALM) sites, and the Biocomplexity of Patterned Ground transect in northern Alaska, as well as ongoing applied research being conducted by the oil industry at Prudhoe Bay.

Each day of the trip will have a different focus:

Day 1: Fire in the boreal forest and effects on permafrost and the active layer

Day 2: Permafrost and periglacial processes in the alpine region of the Brooks Range

Day 3: Permafrost and ecosystem change through time: Glacial history of the Toolik Lake region

Day 4: Patterned-ground, permafrost, and ecosystem change along the Arctic climate gradient

Day 5: Industrial development in the Arctic: The Prudhoe Bay oil field 


\section{OVERVIEW OF THE DALTON HIGHWAY}

Oil was discovered at Prudhoe Bay in 1968, and by 1969 plans had been drawn to build a 1,290 km (800 mi) pipeline from North America's largest oil field at Prudhoe Bay to the ice-free port in Valdez. Before pipeline construction could begin, it was necessary to build a year-round road that paralleled the pipeline route. The Elliott Highway already existed in 1969 but was a very rough, $245 \mathrm{~km}$ (152 mi) mostly gravel road providing access north to the gold-mining settlement at Livengood, and then Manley to the west. The first stretch of the Dalton Highway (91 km [57 mi], from Livengood to the Yukon River) was built in the winter of 1969-1970 by Alyeska Pipeline Service Company. Alyeska built the road's northern $580 \mathrm{~km}$ (360 mi), beginning at the Yukon River, in 1974, in just 5 months (154 days); 24 million $\mathrm{m}^{3}$ (32 million $\mathrm{yd}^{3}$ ) of gravel were used in its construction. The presence of permafrost was a major challenge in the construction of both the road and the pipeline. The road is elevated with layers of gravel and, occasionally, styrofoam boards, in an attempt to prevent loss of permafrost due to the destruction of soil-insulating vegetation.

The highway was open only to commercial traffic until 1981, when the State of Alaska allowed public access to Disaster Creek at Dalton milepost 211. In 1994, public access was allowed all the way to Deadhorse for the first time. The oil pipeline parallels the highway for most of

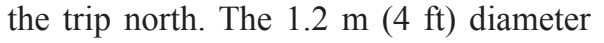
pipeline, built in 1975-1976, is capable of transporting 2 million barrels of oil a day, 365 days a year.

\section{ITINERARY}

Figure 3 shows the route of the field trip and the stops that are planned. The mileposts in this guidebook correspond to the existing small green mile markers along the road. Participants should also follow the route in Brown and Kreig (1983). The Elliott and Dalton highways have been rerouted in some stretches and the mile markers along the route have changed, so the same points may have different milepost references in each source. Mileage along the Elliott Highway (milepost designations E) starts at Fox, 10 miles north of Fairbanks; mileage along the Dalton
Highway (milepost designations D) begins at the Manley turnoff (mile 73 on the Elliott Highway).

\section{Day 1}

Overview: Fairbanks to Coldfoot Camp (539 km [337 mi]). The first day will provide an overview of the terrain, glacial geology, climate, permafrost conditions, and ecology in the boreal forest on the south side of the Brooks Range. Much of the day will be spent driving to Coldfoot. Major stops will be made at: (1) the Yukon River for lunch and a discussion of the Yukon River bridge and pipeline construction; (2) areas where the 2004 wildfires impacted large areas near the road south of Finger Mountain; and (3) the tors and other periglacial features on Finger Mountain. Minor stops will be

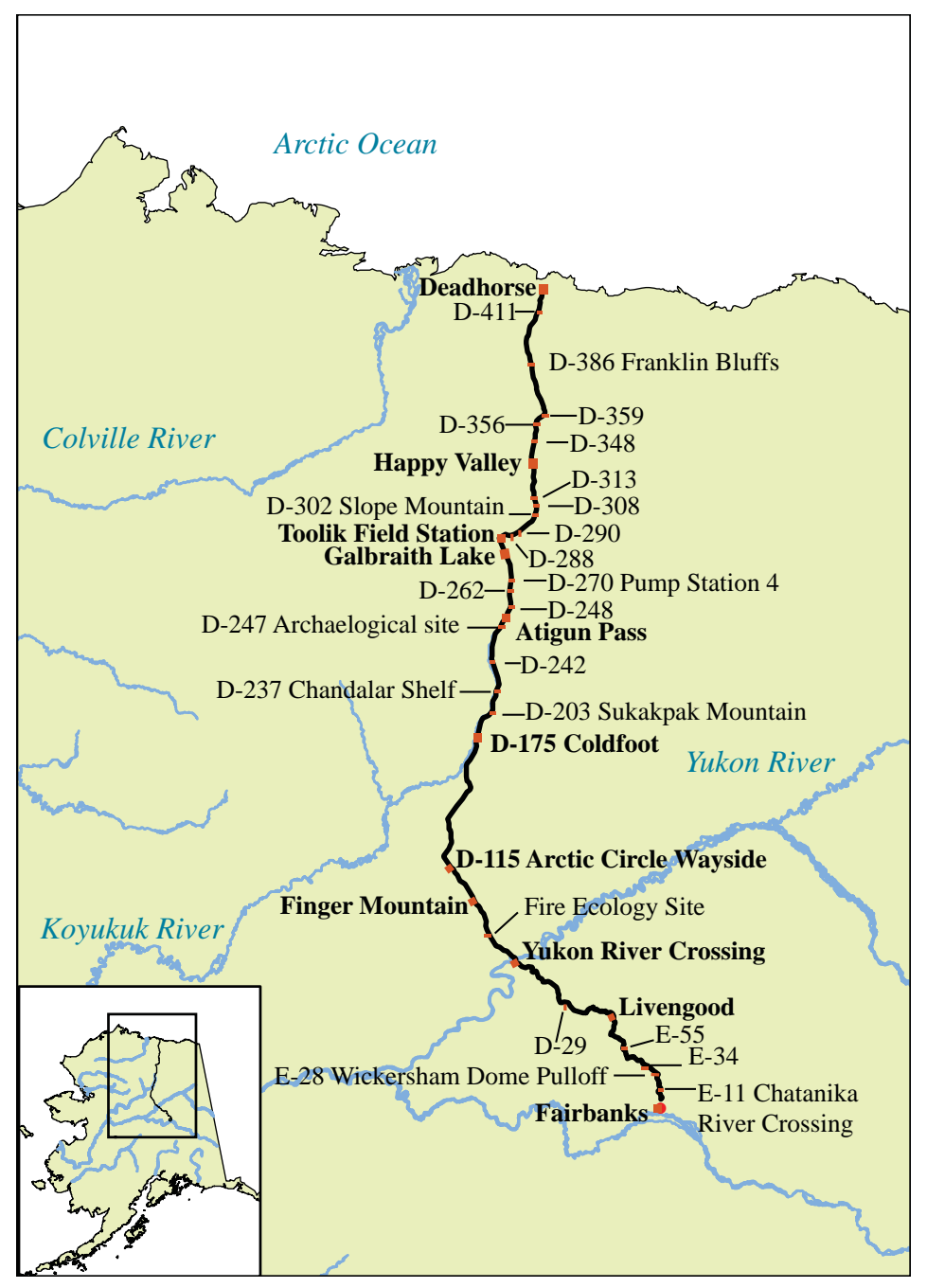

Figure 3. Route of the Dalton Highway field trip. Mileage along the Elliott Highway (designated by E) starts at Fox, 10 mi north of Fairbanks; mileage along the Dalton Highway (designated by D) begins at the Manley turnoff (mile 73 Elliott Highway). 
made for examining boreal forest landscape-ecosystem relationships, areas impacted by the leaf-miner outbreak, other photo opportunities, and restroom breaks. In the evening we will eat dinner at Coldfoot Camp and listen to a presentation by BLM personnel regarding climate change and permafrost in the boreal forest.

Milepost E-28, also see Stop 2, milepost E-39, boreal forests on north- and south-facing slopes (views from the bus)

Brown and Kreig, 1983, p. 54

View of north- and south-facing slopes just beyond Wickersham Dome trailhead parking lot.

\section{Leaf miner outbreak}

Interior Alaska has experienced a recent infestation of aspen leaf miners, Phyllocnistis populiella. According to forest health specialists the infestation covered 236,500 ha $(584,400 \mathrm{ac})$ in 2004 , after expanding from only 570 ha (1,400 ac) in 2000 (Rozell, 2005). These tiny white moths lay their eggs on the leaves of aspens (Populus tremuloides) in the early spring. The larvae then feed on aspen leaves, creating tiny mazes that make the leaves appear silver rather than their normal dark green. After about three weeks, the leaf miners emerge as adult moths and are able to survive an entire year, spending the winter under the snow (Rozell, 2005) (fig. 4). Recent research indicates that young aspens with more abundant extrafloral nectaries suffer less leaf miner herbivory (Wagner and others, 2007).

Milepost E-31.2, “Leaving Fairbanks North Star Borough" sign

Boroughs are Alaska's equivalent to counties. The Fairbanks North Star Borough is located in the heart of Interior Alaska, and is the second-largest population center in the state. The area of the borough is $19,078 \mathrm{~km}^{2}\left(7,366 \mathrm{mi}^{2}\right)$ of land and $201 \mathrm{~km}^{2}\left(78 \mathrm{mi}^{2}\right)$ of water. As of the 2006 census, there were 86,754 people (4.54 people $/ \mathrm{km}^{2}$ ), 7.8 percent of whom are Alaska Natives.

Interior Alaska experiences seasonal temperature extremes. January temperatures range from -54 to $10^{\circ} \mathrm{C}$ (-66 to $50^{\circ} \mathrm{F}$ ). July temperatures range from -1 to $37^{\circ} \mathrm{C}$ (30 to $99^{\circ} \mathrm{F}$ ). Annual precipitation is $26.3 \mathrm{~cm}(10.4 \mathrm{in})$, with $172.2 \mathrm{~cm}$ (67.8 in) of snowfall. During the winter months, if the temperature drops below $29^{\circ} \mathrm{C}\left(-20^{\circ} \mathrm{F}\right)$, ice fog can occur. Fairbanks is known for its lingering summer days; when the solstice arrives, there are more than 22 hours of possible daylight.

While Koyukon Athabascans have lived in this area for thousands of years, Fairbanks was not developed until the Chena steamboat landing brought many nonNatives to Fairbanks during the Pedro Dome gold rush. The population of the area continued to increase after construction of the Alcan Highway through Canada and the trans-Alaska oil pipeline.

\section{Stop 1: Milepost E-34, buried and elevated pipe- lines at ecosystem-permafrost transition}

Brown and Kreig, 1983, p. 56

Visible to the north are both buried and above-ground sections of pipeline (fig. 5). Soil sampling and other means were used to determine permafrost conditions along the pipeline route. Where thaw-stable soils were found, the pipeline was buried. In areas of ice-rich permafrost, and where heat from the oil in the pipeline might cause thawing and consequent loss of soil foundation stability, the pipeline was insulated and elevated above ground by vertical supports. Stunted spruce (elfin forest) vegetation on the toe slope is indicative of icerich permafrost conditions that may be related to a relict solifluction slope.

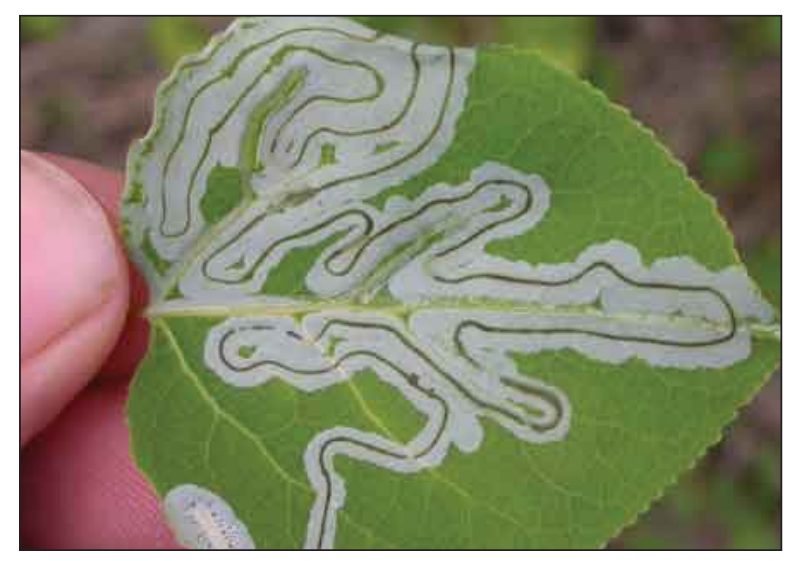

Figure 4. (Left) Leaf miner moth on newly opened bud. (Right) Leaf miner trails on quaking aspen leaf. Photos courtesy of N. Rozell, University of Alaska Geophysical Institute http://www.gi.alaska.edu/ScienceForum/ ASF17/1753.html 


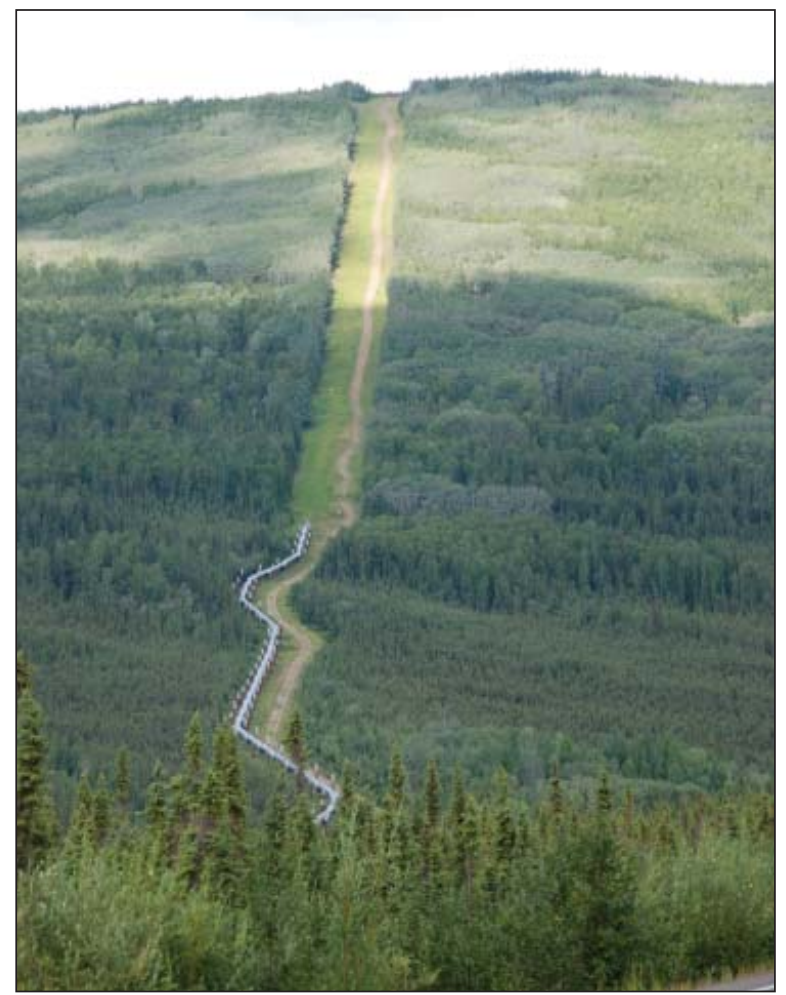

Figure 5. Pipeline transition between buried and elevated mode at permafrost boundary. Note shift from stunted spruce on footslope to taller trees. Photo by D.A. Walker.

Vertical supports placed in drilled holes or driven into the ground elevate above-ground sections. In warm permafrost and other areas where heat might cause undesirable thawing, each support contains two pipes, $5.1 \mathrm{~cm}$ ( 2 in) in diameter, called "heat pipes," filled with anhydrous ammonia, which vaporizes below ground, rises and condenses above ground, removing ground heat whenever the ground temperature exceeds the temperature of the air. Heat is transferred through the walls of the heat pipes to aluminum radiators atop the pipes. Above-ground sections of the pipeline are built in a zig-zag configuration to allow for expansion or contraction of the pipe resulting from temperature changes. The design also allows for pipeline movement caused by an earthquake (http://www.alyeska-pipe. com/pipelinefacts.html).

Buried pipe is underlain with a layer of fine bedding material and covered with prepared gravel padding and soil fill material in a ditch from 2.5 to $5 \mathrm{~m}(8-16 \mathrm{ft})$ deep in most locations, but up to $15 \mathrm{~m}$ (49 ft) deep at one location. In areas where ice-rich permafrost called for elevated pipeline construction, but where the pipeline had to be buried for the highway, animal crossings, or avoidance of rockslides and avalanches, the line was insulated to protect the permafrost from the heat of the pipeline and buried. In some areas the line was insulated and buried in a refrigerated trench. Refrigeration plants at each of these points circulate chilled brine through loops of $15 \mathrm{~cm}$ ( 6 in) diameter pipe to maintain the soil in a stable frozen condition (http://www.alyeska-pipe. $\mathrm{com} /$ pipelinefacts.html).

In northern Alaska the change from discontinuous to continuous permafrost is gradual. Notice that there is less and less buried pipeline as we progress northward.

\section{Steppe grasslands on south-facing slopes}

Visible from the bus at Elliott Highway Milepost 38 and Milepost 61 are steep, xeric, south-facing slopes too dry for spruce. Some of the plants in these areas are not found elsewhere in the Yukon or Alaska. These areas are considered to be Arctic steppe relicts from the Pleistocene.

\section{Stop 2 (optional): Milepost E-39, good views of north and south facing hill slopes}

In the discontinuous permafrost of the boreal forest, there is generally a relationship between aspect, presence of permafrost, and vegetation. On south-facing slopes permafrost is often absent or very deep, hence these slopes commonly support mostly deciduous trees such as aspen (Populus tremuloides), balsam poplar (Рориlus balsamifera), and paper birch (Betula papyrifera) (fig. 5). North-facing slopes, on the other hand, have a shallower active layer and therefore support more spruce. These differences are visible from the vantage point of this stop.

\section{Stop 3: Milepost E-57, Tolovana River Bridge, Colorado Creek Trailhead, black spruce forest White Mountain trail system}

At the Tolovana River bridge, there is a large parking area and access to the White Mountains National Recreation Area, including the Colorado Creek Cabin and the White Mountain Trail system. This is mainly a winter trail system with 220 miles of maintained winter trails and 14 public recreation cabins surrounded by jagged limestone mountains and cliffs, high mountain passes, and broad, rounded valleys. Snowmobiling, dog mushing and cross-country skiing have long been popular winter pastimes in the White Mountains National Recreation Area. Skijoring (cross-country skiing while being pulled by dogs) and mountain biking are rapidly growing winter sports.

\section{Black spruce forests}

North of the trailhead is an area where we will spend some time in a black spruce forest, the dominant forest type of interior Alaska (bring your head net and mosquito repellent!). 
Northern Alaska's boreal forests have two types of spruce: white spruce (Picea glauca) and black spruce (Picea mariana). White spruce generally is found on better drained, less acidic soils, whereas black spruce can survive in acidic wet peat. Black spruce also have a very shallow root layer and can grow in an active layer only $25 \mathrm{~cm}$ (10 in) thick (Pielou, 1994).

Spruce twigs can be used to identify the species. While the twigs of white spruce are light colored (tan or pale green) and hairless, the black spruce twigs have a fuzz of dark brown hairs. Additionally, the cones of black spruce are small and egg-shaped, while white spruce cones are more elongated (Pielou, 1994). Driving north of Stop 2, many black spruce are visible with classic tufted tops. These tufted tops are indicators of black spruce, though not all black spruce have them; their absence does not necessarily indicate a white spruce. A more complete discussion of the vegetation-soil-terrain relationships is contained in Brown and Kreig (1983, p. 26-35).

\section{Bonanza Creek Long Term Ecological Research (LTER) site}

Much of the fire research along the Dalton Highway is conducted by the U.S. Forest Service in collaboration with the Bonanza Creek LTER project at the University of Alaska Fairbanks. The Bonanza Creek LTER was established in 1987, with the Bonanza Creek Experimental Forest (BCEF) as its primary research site. BCEF is located approximately $20 \mathrm{~km}(12 \mathrm{mi})$ southwest of Fairbanks, Alaska, and was established in 1963 on about 3,360 ha $(8,300 \mathrm{ac})$ of upland, interior Alaska boreal forest (http://www.lter.uaf.edu/bcef/default.cfm). In 1969, the experimental forest was enlarged to 5,053 ha $(12,487 \mathrm{ac})$ to include representative floodplain forests along the Tanana River. The forest is within the Tanana Valley State Forest, a unit managed by the Alaska Department of Natural Resources, Division of Forestry.

\section{Stop 4 (optional): Milepost E-70, Livengood turnoff}

Restroom facilities

Note the turnoff to Livengood, an old mining district. Milepost E-73 marks the end of the Elliott Highway, the beginning of the Dalton Highway and gravel road, and the turnoff to Manley.

\section{Stop 5: Milepost D-29, fire ecology photo stop}

This site provides views of the area burned by the Erickson Creek fire (2003) and a view to the west of the older Hess Creek fire and the Hess Creek drainage. This fire occurred the year before the 2004 fire season and is a somewhat later stage of succession than the site at Stop 7 (see for more information on fires).

\section{Stop 6: Milepost D-56, Yukon River and E.L Patton Bridge}

Brown and Kreig, 1983, p. 79

The Yukon River is the largest river in Alaska, winding about $3,700 \mathrm{~km}(2,300 \mathrm{mi})$ from Canada to the Bering Sea. It is the fifth longest river in North America and the 21 st longest in the world. At the Yukon River crossing we will stop for lunch, visit the BLM Yukon Crossing Visitor Contact Station, a wetland fire ecology research site, and view the Yukon River.

Fire burns thousands of acres in Alaska every year. Many factors determine the severity of a fire, but in a wetland area, site moisture and drainage are integrally linked to potential fire severity. Wetlands will rarely burn as severely as drier upland sites. However, wetlands also contain large amounts of soil carbon, much of which is located in the permafrost beneath these wetlands. Fire has a strong impact on permafrost distribution, and under the right conditions, can have an effect on site drainage by burning away soil carbon and changing the permafrost regime (see Appendix E for permafrost temperatures).

\section{Milepost D-78.2, Cryoplanation terraces}

Cryoplanation terraces, carved from bedrock by frost weathering, nivation, and solifluction processes, are well developed on the flanks of Caribou Mountain west of the Dalton Highway. Their scarps typically range in height up to about $15 \mathrm{~m} \mathrm{(} \sim 50 \mathrm{ft})$ and stand at moderate to steep angles that can approach nearly vertical. Terrace treads are gently sloping, and can extend over several kilometers. They consist of bedrock covered by a thin blanket of rock rubble that commonly is sorted into stone networks.

\section{Stop 7: Milepost, D-85.7, fire ecology research, U.S. Forest Service}

The boreal forest, which stretches across three continents and encircles the Arctic, depends on fire to regenerate and maintain its health. Fires, although potentially destructive to property and harvestable timber, increase forest diversity and restore soil nutrients by breaking down organic matter. Most large fires are started by lightning, while small fires are most often human-initiated.

In 2004, Alaska's biggest fire year on record, 706 fires (272 lightening-caused and 434 human-caused) burned more than 2,711,393 ha (6.7 million ac), an area the size of Massachusetts. Hot, dry, windy weather returned in 2005, making it the third biggest year with more than 1,780,617 ha (4.4 million ac) burned. Several fires burned along the Dalton Highway in both years (fig. 6). In recently burned areas, fields of bright pink fireweed (Epilobium angustifolium), an early colonizer of burned areas, leads the way for regrowth that will eventually feed much more wildlife. 
Variations in local topography, site moisture, and vegetation type all interact with weather conditions to influence the intensity, severity, and spatial configuration of a burn. Highly flammable black spruce forests cover more than 40 percent of interior Alaska and these forests can sustain severe, extensive, and persistent fires under the right weather conditions. Understanding the successional trajectories following fires is important because future stand development will influence future forest flammability. Three of the most important factors in determining post-fire successional trajectories are: Pre-fire species composition, site moisture (including topography, soil texture, and presence of permafrost), and burn severity (or the amount of organic material consumed by the fire).

\section{Milepost D-97, Alpine treeline on Finger Mountain}

Note the flagged trees at treeline here, indicative of windy winter conditions.

\section{Stop 8: Milepost D-98, Finger Mountain}

Brown and Kreig, 1983, p. 99-103

The landforms of this area have been shaped by periglacial processes last active during the last ice age (24,000-16,000 years ago). The granite tors of Finger Mountain are surviving remnants of large, unglaciated bedrock hills that were broken down by frost shattering during times characterized by extensive areas of late snow, low summer temperatures, frequent freeze-thaw cycles, and sparse vegetation cover (fig. 7). The granite of these tors is from a pluton of Cretaceous age (about 110 million years ago) and is porphyritic, containing unusually large phenocrysts of feldspar set in a fine-grained matrix of quartz and other minerals. What appears to be coarse sand on the ground is actually grus, which consists of individual crystals of feldspar and quartz from broken-down granite. Fractures in the granite have been penetrated by water, which freezes, expands, and

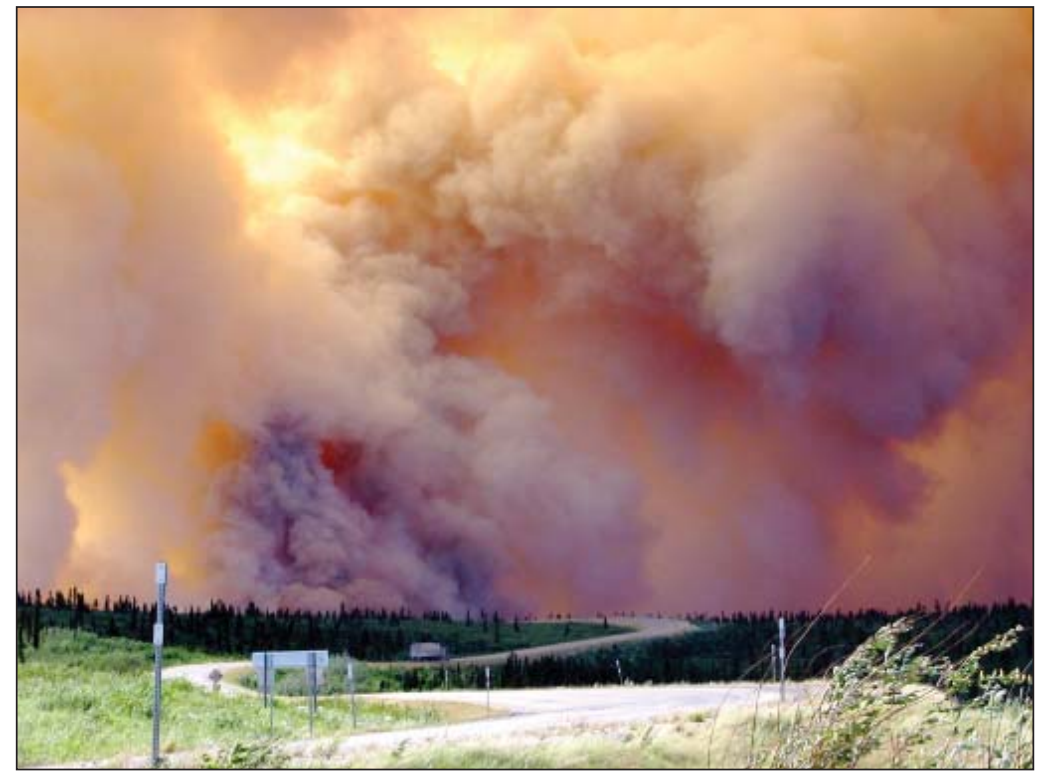

Figure 6. (Top) Fire on Gobbler's Knob, June 2005; (Bottom) fireweed display following the fires. Photos by D.A.Walker.

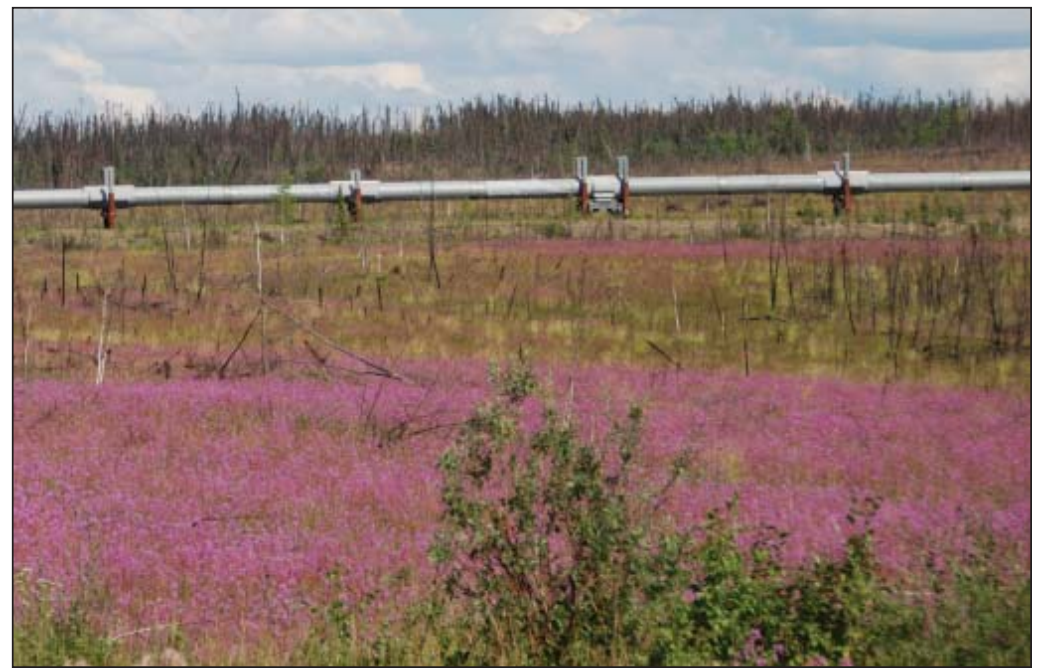




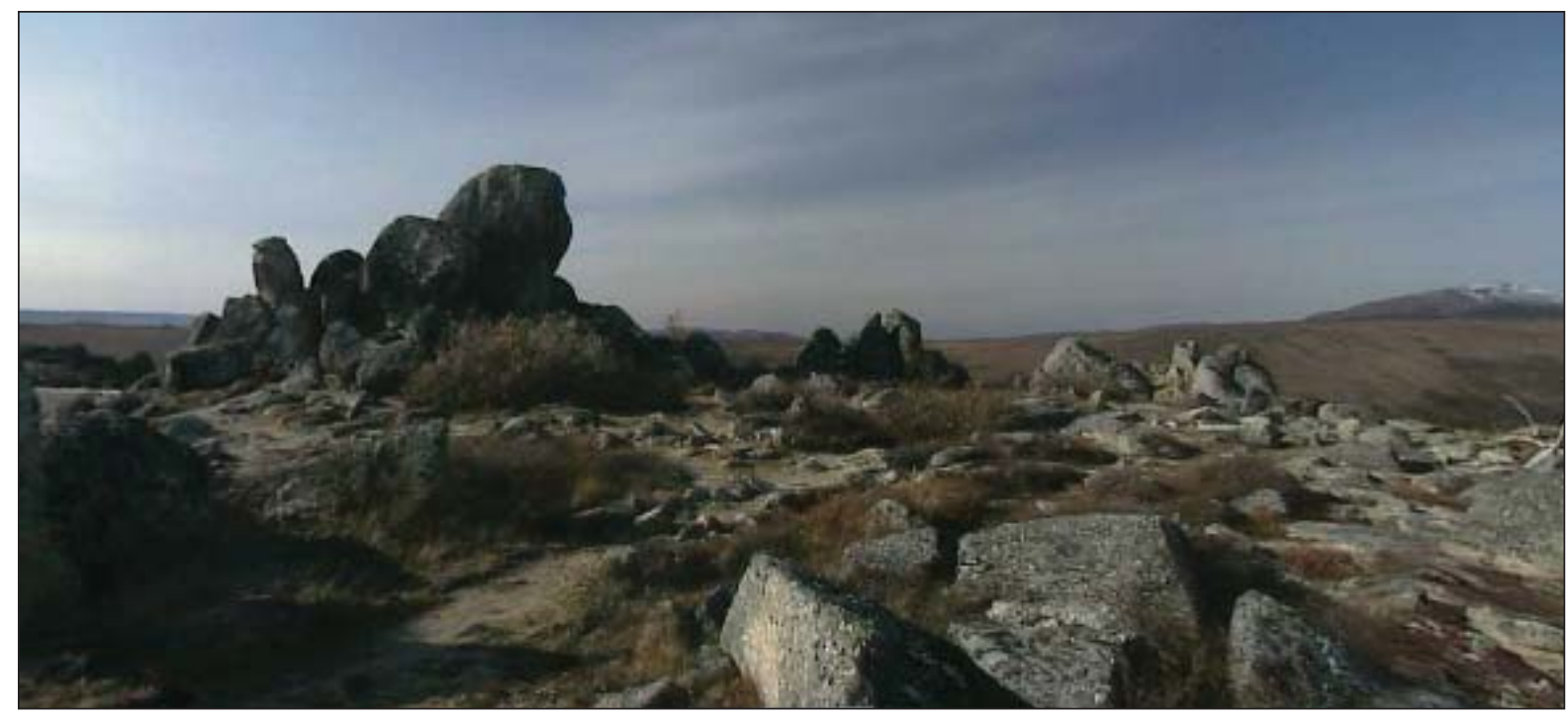

Figure 7. Tor at the Finger Mountain overlook. Photo courtesy of R. Stehle, Palo Alto, CA http://www.windband. org/alaska/finger_mtn/finger_mtn.htm

mechanically breaks apart the bedrock. The resulting debris moves downslope from its source by solifluction and other mass-wasting processes. While waterlogged soil and sediments in this area are likely still slowly moving downslope within the active layer above the permafrost, the extensive lichen cover on most of the granite blocks suggests that frost action has stopped in this area and that boulders are stabilized. Sorted circles can be found where reduced slope angles restrict movement by solifluction (Diel and Banet, 1993).

\section{Stop 9: Milepost D-115, Arctic Circle}

Brown and Kreig, 1983, p. 108

Restroom facilities; photo opportunity

The Arctic Circle is the invisible circle of latitude on the earth's surface at about $66^{\circ} 33^{\prime}$ 'north, marking the southern limit of the area where the sun

Figure 8. Arctic Circle marker. Photo by D.A. Walker. does not rise on the winter solstice, or set on the summer solstice (fig. 8). It is approximately $2,655 \mathrm{~km}(1,650 \mathrm{mi})$ from the North Pole.

\section{Stop 10: Milepost D-175, Coldfoot Camp}

Brown and Kreig, 1983, p. 129

This stop gives an opportunity to visit the Coldfoot multi-agency visitor center run by the Bureau of Land Management, National Park Service, and U.S. Fish \& Wildlife Service (fig. 9). This beautiful facility opened in 2004, replacing the one-room log cabin that functioned as a visitors' center for 16 years. Dining and lodging are available for visitors at Coldfoot.

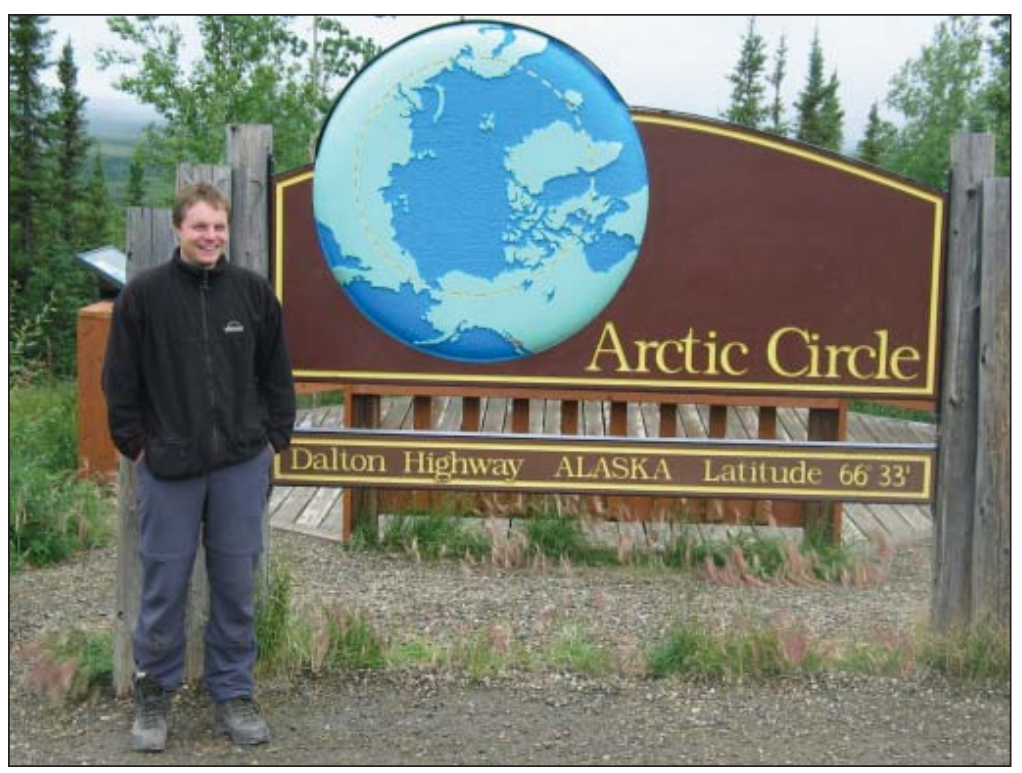




\section{DAY 2}

Overview: Coldfoot to Toolik Lake Field Station (162 km [101 mi]). Day two will be spent primarily in the alpine area of Atigun Pass. Before reaching the alpine area we will stop at the unusual ice mounds near Sukakpak Mountain, and at treeline. Most of the day will be spent examining characteristic alpine features, including a pingo near Chandalar Camp, solifluction features, an alpine cirque, an alpine wetland, a rock glacier, and a debris slope. We will eat lunch on the Continental Divide while discussing characteristics shared by alpine tundra and High Arctic ecosystems, and enjoy a relaxed day in the alpine. After leaving the alpine in the afternoon, we will visit an unusual aufeis area and some non-sorted circles near Galbraith Lake. We will then drive to Toolik Lake, where we will eat dinner and spend the night.

\section{Stop 11: Milepost D-204, Sukakpak Mountain}

Brown and Kreig, 1983, p. 139-143

\section{Sukakpak Mountain}

The massive marble rock of Sukakpak Mountain, rising to $1,338 \mathrm{~m}(4,459 \mathrm{ft})$, was deposited in a marine environment about 380 million years ago (fig. 10). Since that time the limestone has been subjected to high temperature and pressures and has metamorphosed into marble. "Sukakpak" is an Inupiat Eskimo word meaning
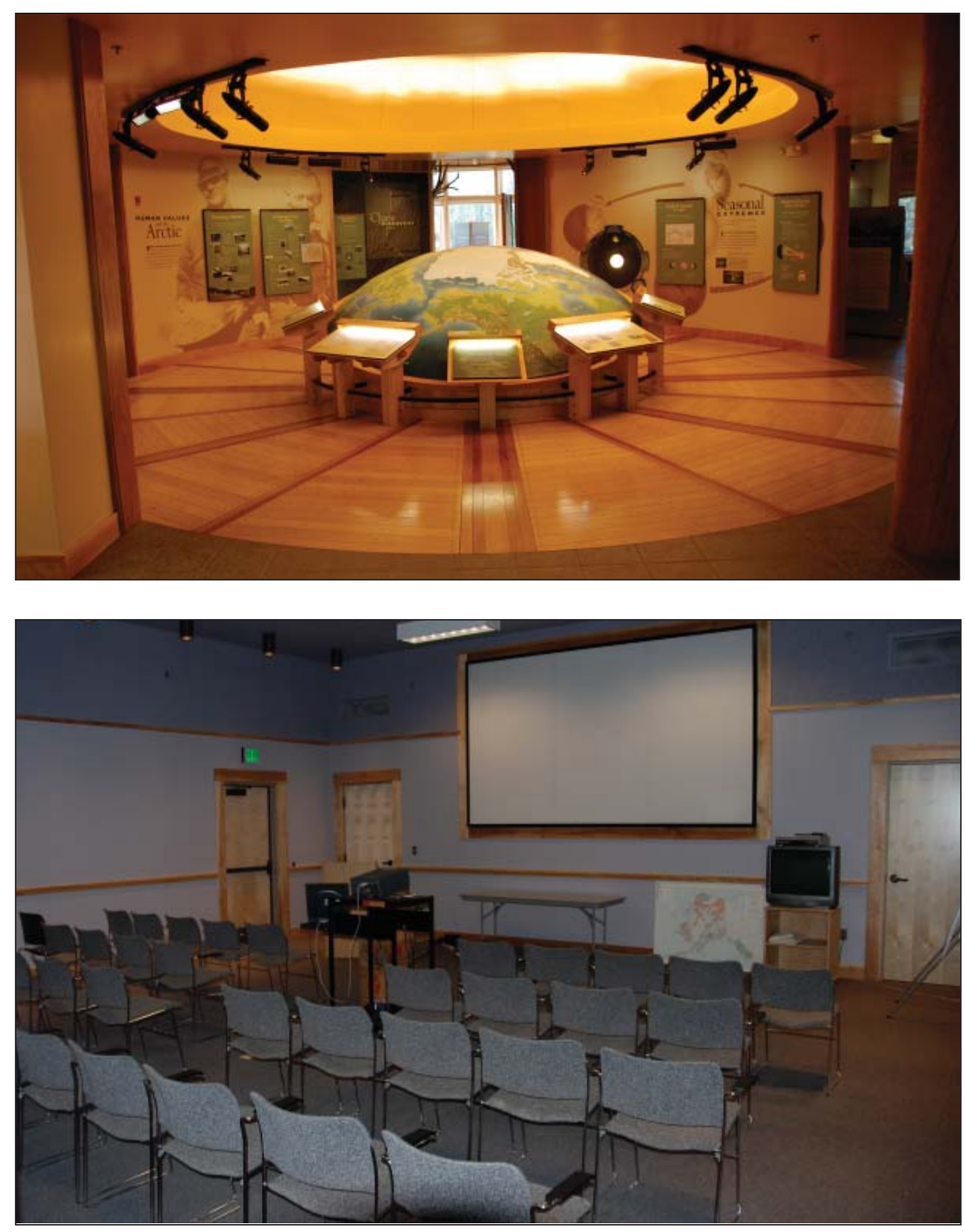

Figure 9. Multi-agency Visitor Center at Coldfoot. Photos by D.A. Walker. 
"marten deadfall." Seen from the north, the mountain resembles a carefully balanced log used to trap marten (Diel and Banet, 1993).

\section{Ice-cored mounds and fen vegetation}

Numerous low ice-cored mounds occur on the gentle slope at the base of Sukakpak Mountain. Ice-cored mounds, some of which are topped by trees, are visible at the mountain's base. These small mounds probably form by the freezing of ground water as it moves downslope within the active layer. These mounds are described in Brown and Kreig (1983), p. 139-143, along with a map and descriptions of the species-rich fen vegetation associated with the high $\mathrm{pH}$ soils in the area.

\section{Stop 12: Milepost D-216, Debris slide or rock gla- cier (see Appendix F) \\ Brown and Kreig, 1983, p. 145}

\section{Milepost 230.1, North Slope Borough}

The area between the Chandalar Shelf and the Arctic Ocean and from the Canadian border to the Chukchi Sea is all part of the North Slope Borough (fig. 12). With an area of $230,035 \mathrm{~km}^{2}\left(88,817 \mathrm{mi}^{2}\right)$ of land and $15,399 \mathrm{~km}^{2}$ $\left(5,946 \mathrm{mi}^{2}\right)$ of water, the Borough is larger than Great Britain and Northern Ireland combined. It has a population of 6,607 people (.027 persons $/ \mathrm{km}^{2}, 2006$ census), of whom 72 percent are Alaska Natives.

\section{Milepost 236.8, Arctic Treeline}

The arctic treeline within the Dalton Highway corridor is marked by a dead tree that was formerly acknowledged as the northernmost spruce along the road (fig. 11).
There have been various theories about tree-line advance and how various factors interact to limit the arctic treeline. In the 1930s, nature conservationist Bob Marshall planted white spruce seeds north of the treeline in three separate Brooks Range watersheds to test his theory that trees had not had enough time since deglaciation to occupy their potential growth range. Two of these seedlings are still growing today about $5 \mathrm{~km}(3 \mathrm{mi})$ north of the current tree line (Wilmking and Ibendorf, 2004). Permafrost conditions are likely an important factor limiting northward expansion of spruce, as are persistent snowbeds, soil temperatures, and possibly warming-induced drought.

\section{Stop 13: Milepost D-242, Pingo-like feature near Chandalar Camp \\ Brown and Kreig, 1983, p. 151}

At this stop we will hike to a pingo-like feature on the landscape (fig. 13). Upon examining it, can you tell if it is a pingo, a kame, a bedrock outcrop, or some other geomorphic feature? What characteristics are helpful in its identification?

\section{Stop 14: Milepost D-246, south side of Atigun Pass}

We will make a couple of stops on the way to the summit, during which we will visit several features and discuss some of the common geomorphic processes on this side of the pass, including:

\section{Solifluction lobes and terraces}

The road cuts through colluvium flanking the northwest side of the road. The lower cuts pass through and expose solifluction rubble. We will stop and examine one of the larger solifluction lobes near the start of the

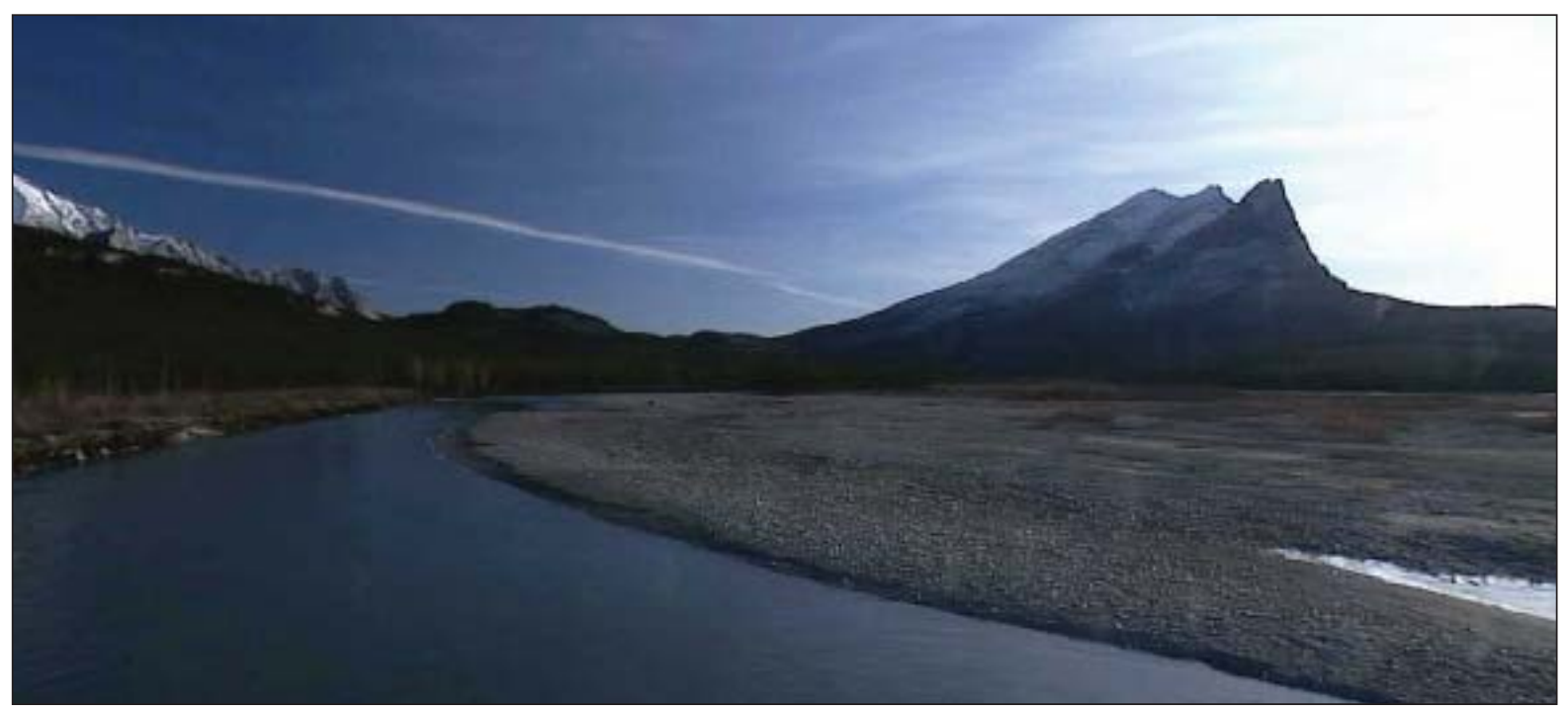

Figure 10. Sukakpak Mountain viewed from the Dietrich River Bridge. Photo courtesy of R. Stehle, Palo Alto, CA http://www.windband.org/alaska/finger_mtn/finger_mtn.htm 


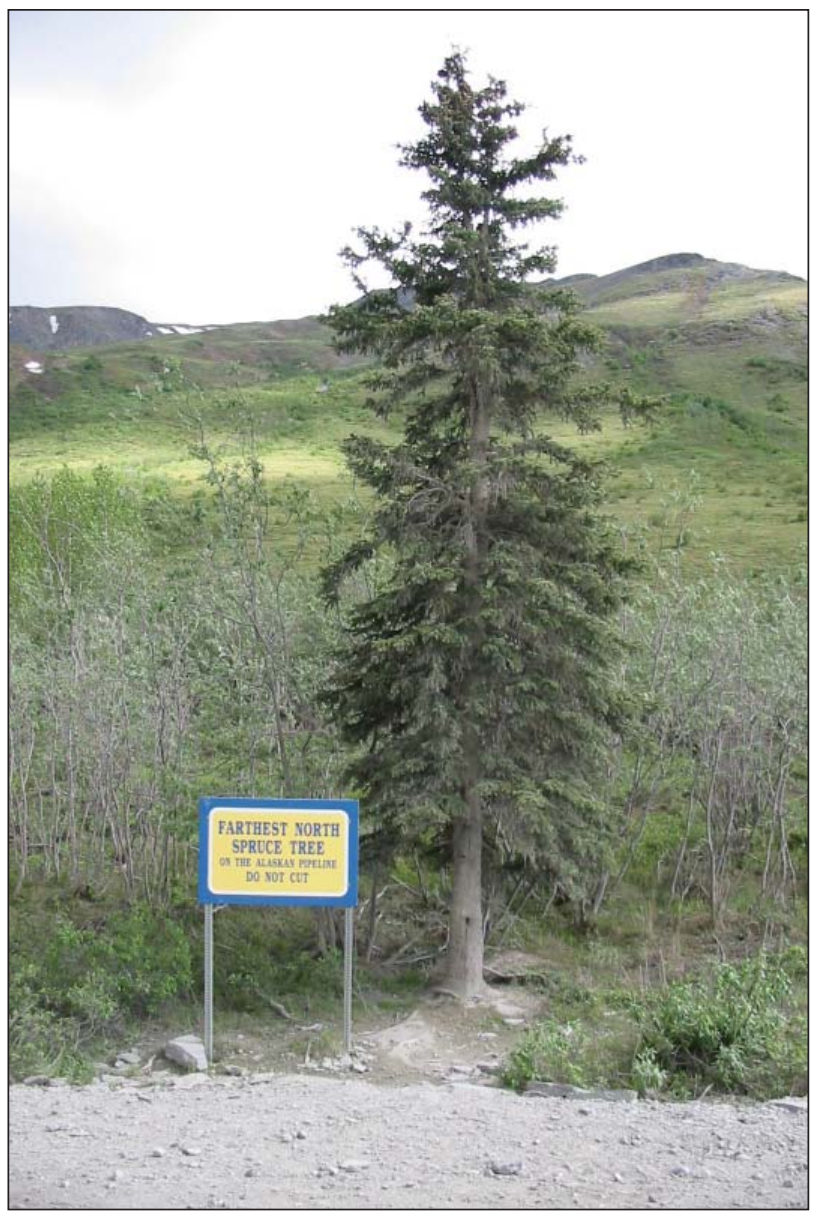

Figure 11. Farthest north spruce tree along the Dalton Highway; photo was taken in 2001 before the tree was girdled and killed. Photo by J.K. Knudson.

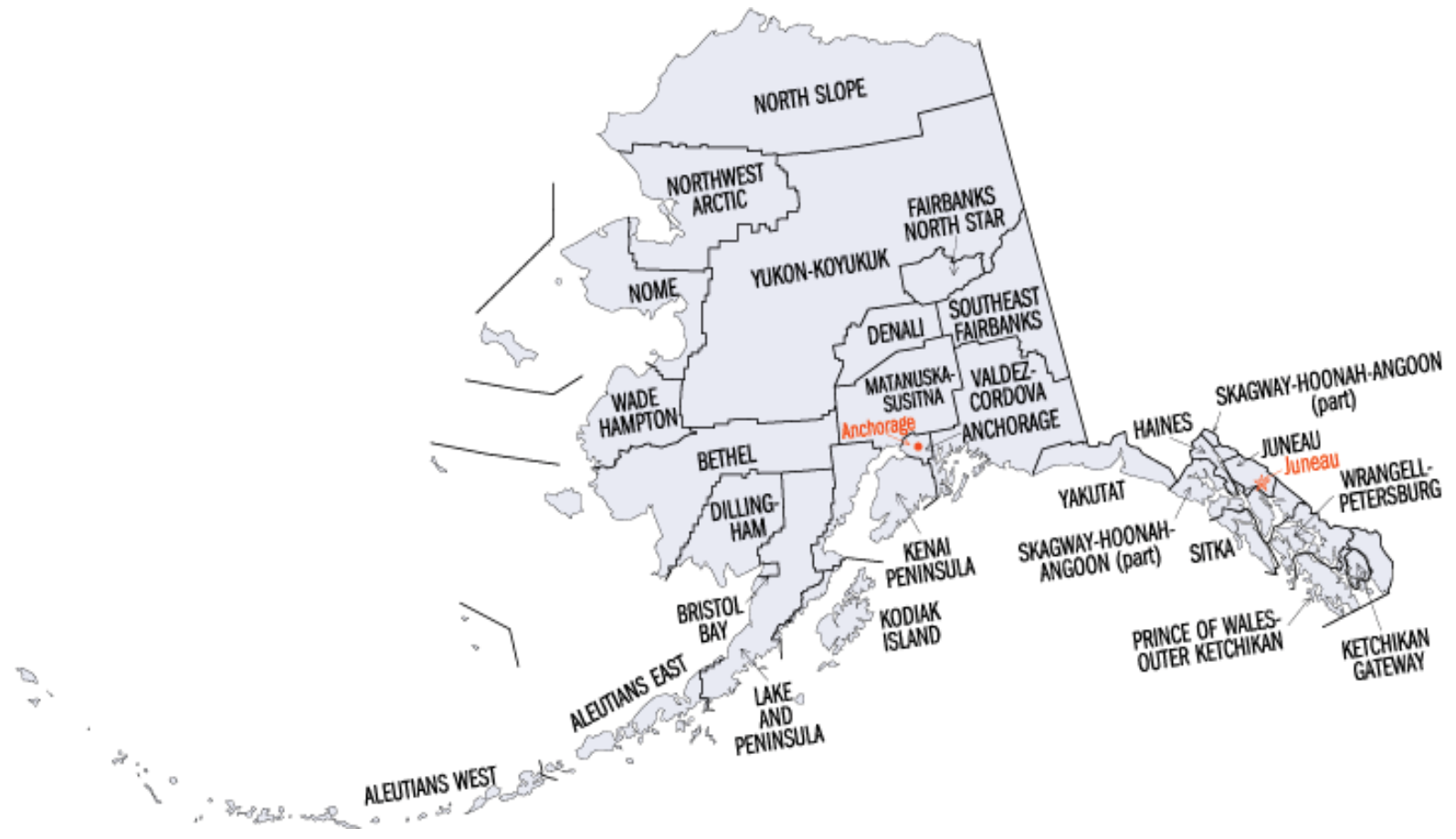

Figure 12. State of Alaska Boroughs. http://quickfacts.census.gov/qfd/maps/alaska_map.html 


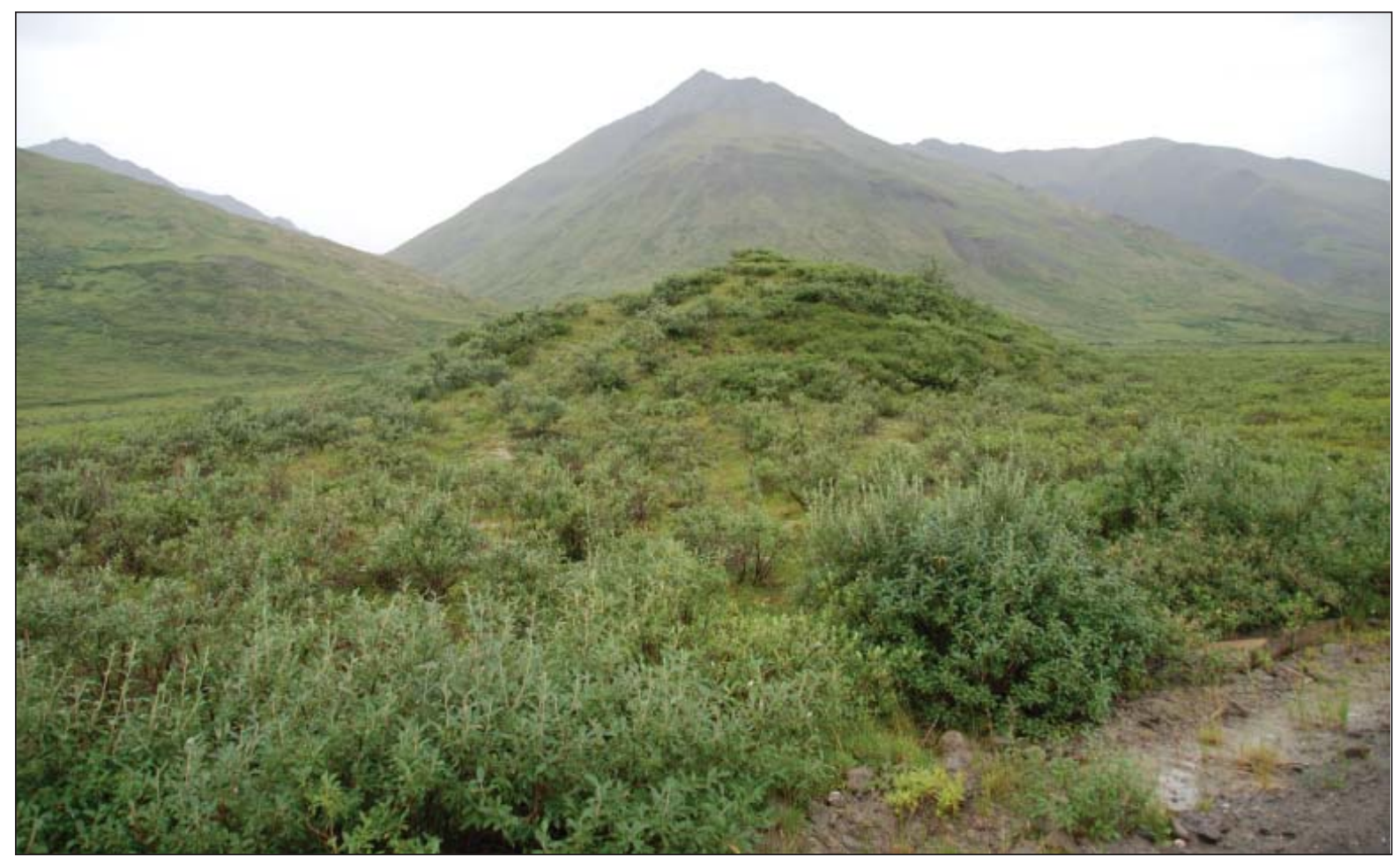

Figure 13. Pingo-like feature near Chandalar Camp. Photo by D.A. Walker.

climb up to the pass (fig. 14). Vegetation, consisting of mostly grasses and forbs that stabilize the front of the soil flowing atop the permafrost, tends to create lobes or terraces. Many of these plants are also disturbance colonizers, such as Epilobium latifolium, suggesting active solifluction is occurring. Heavier vegetation at the lobe's front is favored by more exposure to sunlight, enhanced nutrients, and better soil drainage due to a deeper permafrost table. The nutrients are released by warmer soil temperatures and deeper permafrost. Dwarf willows are common on lobe fronts, and their roots are important for stabilizing the lobes. Snow accumulates at the base of lobes, providing insulation for small creatures such as ground squirrels, lemmings, and voles, and attracting foxes and bears that may dig for them.

\section{Large landslide}

On the north-facing flank of the valley south of the solifluction site, a landslide extended northward into the center of the valley. This very hummocky deposit is typical of landslides in upper valleys near the Continental Divide that occurred either during or immediately after deglaciation. Valley walls were oversteepened by glacial scour, and commonly failed as lateral support of glacial ice was removed during downwastage. Some slides were deposited on the surfaces of stagnant glaciers and developed conspicuous kame and kettle features as the ice continued to downwaste. Episodic stream incision began immediately after deglaciation.

\section{Dall sheep}

If we are lucky we may see Dall sheep (Ovis dalli) on the hillsides on either side of the road (fig. 15). The sheep tend to return again and again on well-worn paths to known salt licks, including some in the Atigun Pass and Slope Mountain area. The minerals they acquire through these salt licks provide an essential component of their diet (Pielou, 1994). O. dalli inhabit the mountain tundra of Alaska and the Yukon, sometimes straying north onto the Arctic coastal plain west of the Mackenzie Delta (Pielou, 1994). The sheeps' agility allows them to escape predation from wolves, grizzlies, and wolverines by climbing onto extremely rough terrain.

\section{Archeological sites in the Atigun Pass area}

Atigun Pass serves as a major pathway that funnels migrating caribou (Rangifer tarandus) through the mountains. Caribou are the most numerous large mammals of the Arctic. Most North American caribou herds spend winter in the boreal forest and migrate northward each spring to bear their young. A couple of months after calving, most of the herd begins the southward migration, though a small number stay behind and spend the winter on the tundra (Pielou, 1994). The concentra- 


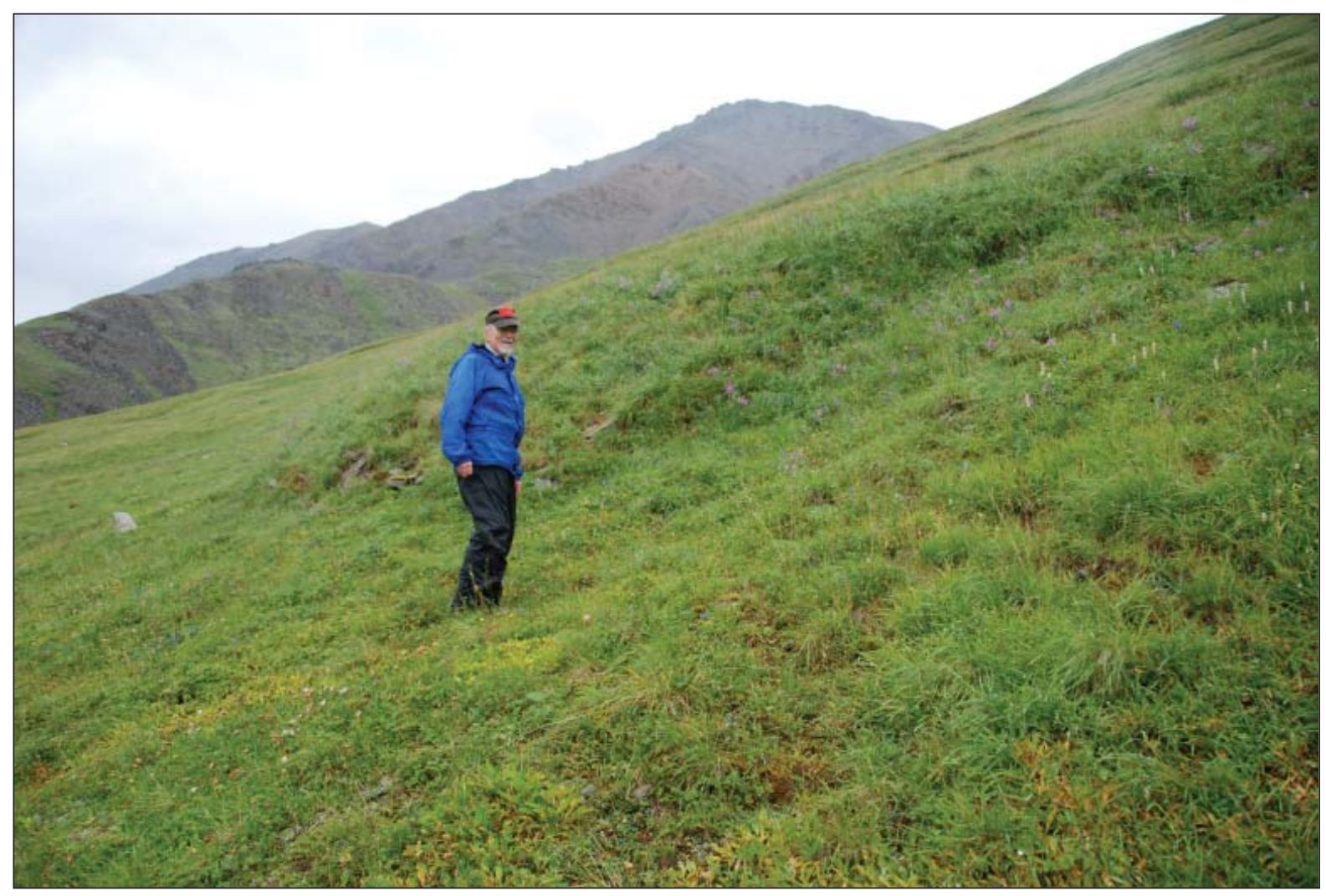

Figure 14. Solifluction lobe, Atigun Pass. Photo by D.A. Walker.

tion of Dall sheep and caribou made Atigun Pass a prime hunting area for Native Alaskans. Prehistorically and historically, the Central Brooks Range was utilized by various Eskimo and Athabascan groups. Caribou supplied meat; hides for clothing, bedding, and tents; sinews for thread; bones for tools; and fat as fuel oil (Pielou, 1994). A hunting blind can be found in the scree on a slope near Atigun Pass (fig. 16). Lichen growing on the rocks that form the blind attests to the age and historical value of the site.

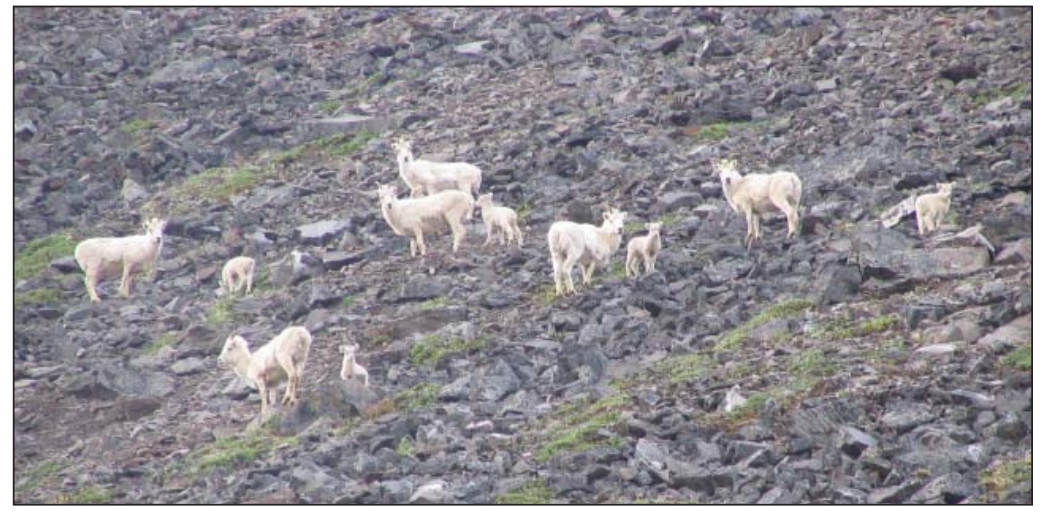

Figure 15. Dall sheep on Atigun Pass. Photo by D.A. Walker.

\section{Stop 15: Milepost D-247, summit of Atigun Pass (1,447 m [4,747.4 ft]), Continental Divide}

Brown and Kreig, 1983, p. 153

The summit of the pass has a wide variety of interesting points that we will visit and discuss including:

\section{CRREL Wyoming snow gauge}

This gauge was one of several erected along the Dalton Highway as part of a climate transect established by the U.S. Army Corps of Engineers Cold Regions Research \& Engineering Laboratory (Haugen, 1982). The fencing material of the shield provides a windbreak to allow snow to settle into the gauge rather than be carried past by winds.

\section{Alpine vegetation and zonation}

Due to adiabatic cooling, temperatures decrease $\sim 6^{\circ} \mathrm{C}$ for every $1,000 \mathrm{~m}\left(\sim 4.5^{\circ} \mathrm{F}\right.$ for every 1,000 feet $)$ gained in elevation.Because temperatures are cooler at higher elevations, the elevational vegetation zonation in alpine areas of the Brooks Range is analogous to the vegetation zonation that occurs latitudinally across the Arctic. 
In high elevation areas in the Low Arctic, such as the Brooks Range, we can observe vegetation communities similar to those that occur in the most northerly Arctic bioclimate subzones (CAVM Team, 2003).

\section{Glacial cirque}

Figure 17 shows the cirque at the top of Atigun Pass that has been vacated by its glacier. In the bottom of the cirque are unique wetland plant communities dominated by lichens (Umbilicaria spp.). For a discus- sion of Holocene glaciation and cirque glaciers in the Atigun Pass area, see Ellis and Calkin (1983) in Brown and Kreig (1983, p. 154-159).

\section{Buried oil pipeline}

Complex oil pipeline engineering was required to bury the pipeline in this section. See the discussion of pipeline engineering and problems encountered during and following construction, including a major oil spill that occurred here in 1979 (Brown and Kreig, 1983, p. 153).

Figure 16. Ancient hunting blind near Atigun Pass. Photo by D.A. Walker.
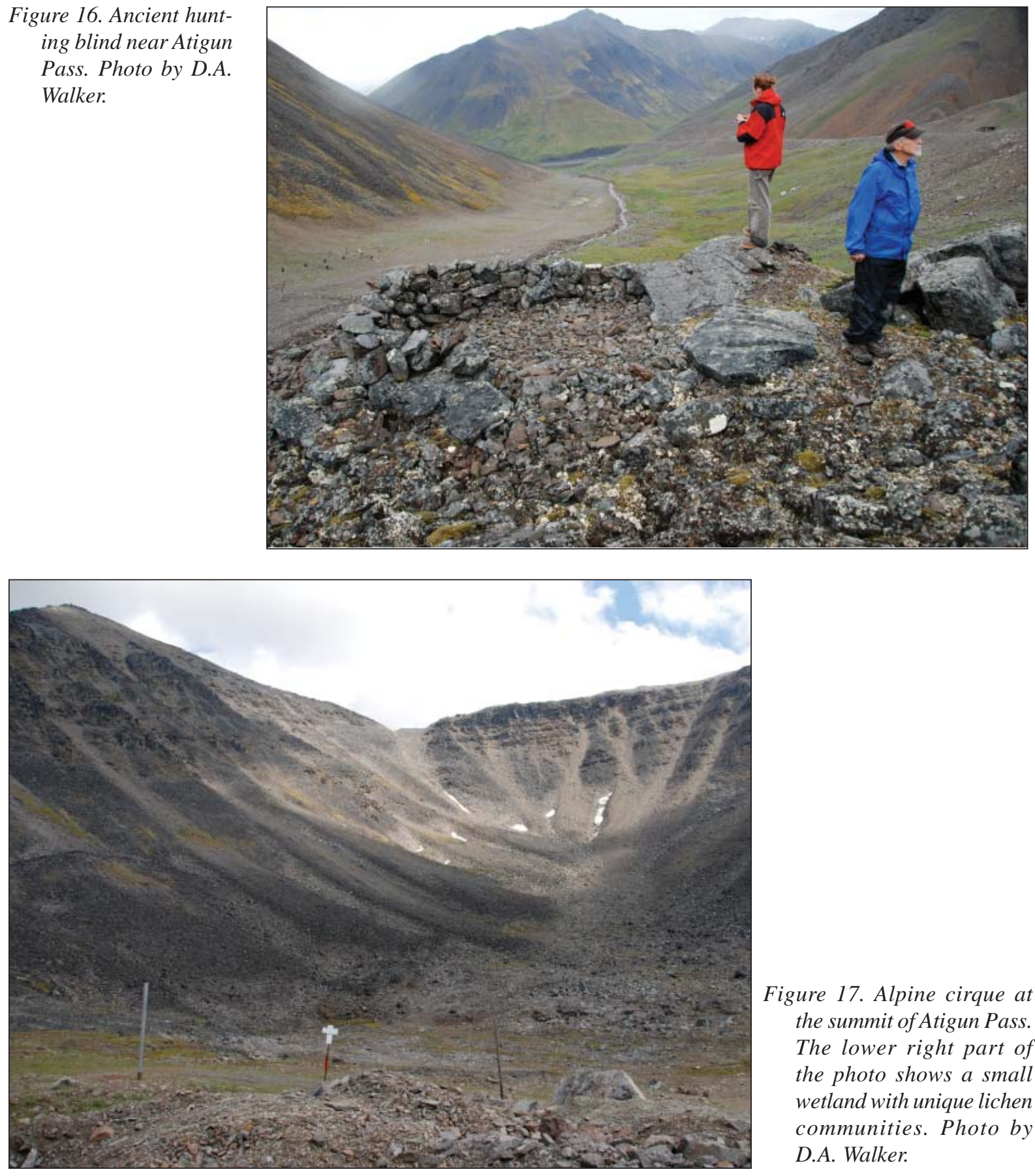

Figure 17. Alpine cirque at the summit of Atigun Pass. The lower right part of the photo shows a small wetland with unique lichen communities. Photo by D.A. Walker. 


\section{Old landslide}

Near the summit on the north side of the pass is a landslide that traveled down the valley head west of the highway, forming the rubble deposit that is dissected by the road. It may have been modified subsequently by rock-glacier creep. Another small alpine wetland with patterned ground features lies near the terminus of the deposit (fig. 18).

\section{Stop 16: Milepost D-248, north side of Atigun Pass}

Alpine areas such as Atigun Pass are subject to diverse rapid mass movements that commonly are most active during springtime. The road intersects several snow-avalanche paths on the north side of the pass. Slush-flow tracks are visible in several steep gorges. Rock debris transported by these processes litters the surfaces of many fans. Spring thaw on steep bedrock slopes also releases frost-shattered blocks that had remained cemented by ice through the winter, and the resulting rockfalls nourish talus cones and aprons along the bases of valley walls. We will make one stop on the north side near the base of the pass to observe several large alluvial fans with slush-flow chutes and deposits and lobate rock glaciers.

\section{Lobate and tongue-shaped rock glaciers}

As we descend into the head of Atigun River valley and follow that valley northward, lobate rock glaciers are visible along the bases of both valley walls (fig. 19). These features form from rockfall debris into which snow meltwater and summer rainfall infiltrate and become permanently frozen ice that fills voids between the angular talus blocks. Deformation of the ice causes the rubble mass to creep outward from the valley sides, forming the steep-fronted lobate rock glaciers.

Tongue-shaped rock glaciers are also common in the Atigun Pass area and at the heads of valleys tributary to Atigun River valley (fig. 19, top). This variety of rock glacier forms on cirque floors, and commonly is cored with stagnant glacier ice - the remains of formerly active cirque glaciers. Further information on lobate and tongueshaped rock glaciers can be found in Brown and Kreig (1983, p. 157-158) and in Ellis and Calkin (1979).

Talus, debris cones, steep alpine fans, slush-flow chutes, alluvial fans, kame terraces, and lateral moraines

The steep glacier-carved flanks of the upper Atigun River valley are dissected by steep ravines, debris chutes, and tributary valleys. A great variety of typical alpine

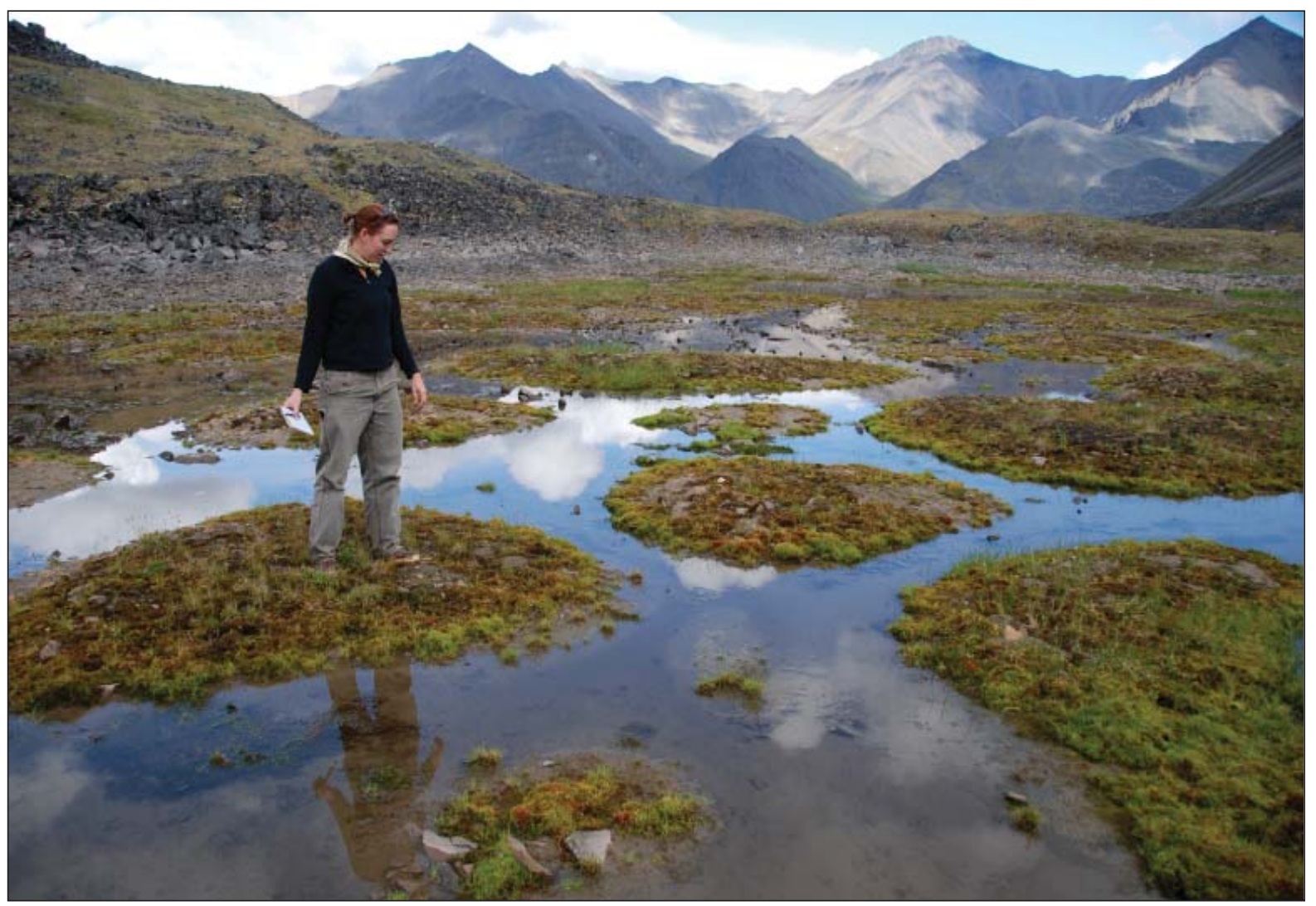

Figure 18. Alpine wetland with sorted circles near the summit of Atigun Pass. Photo by D.A.Walker. 

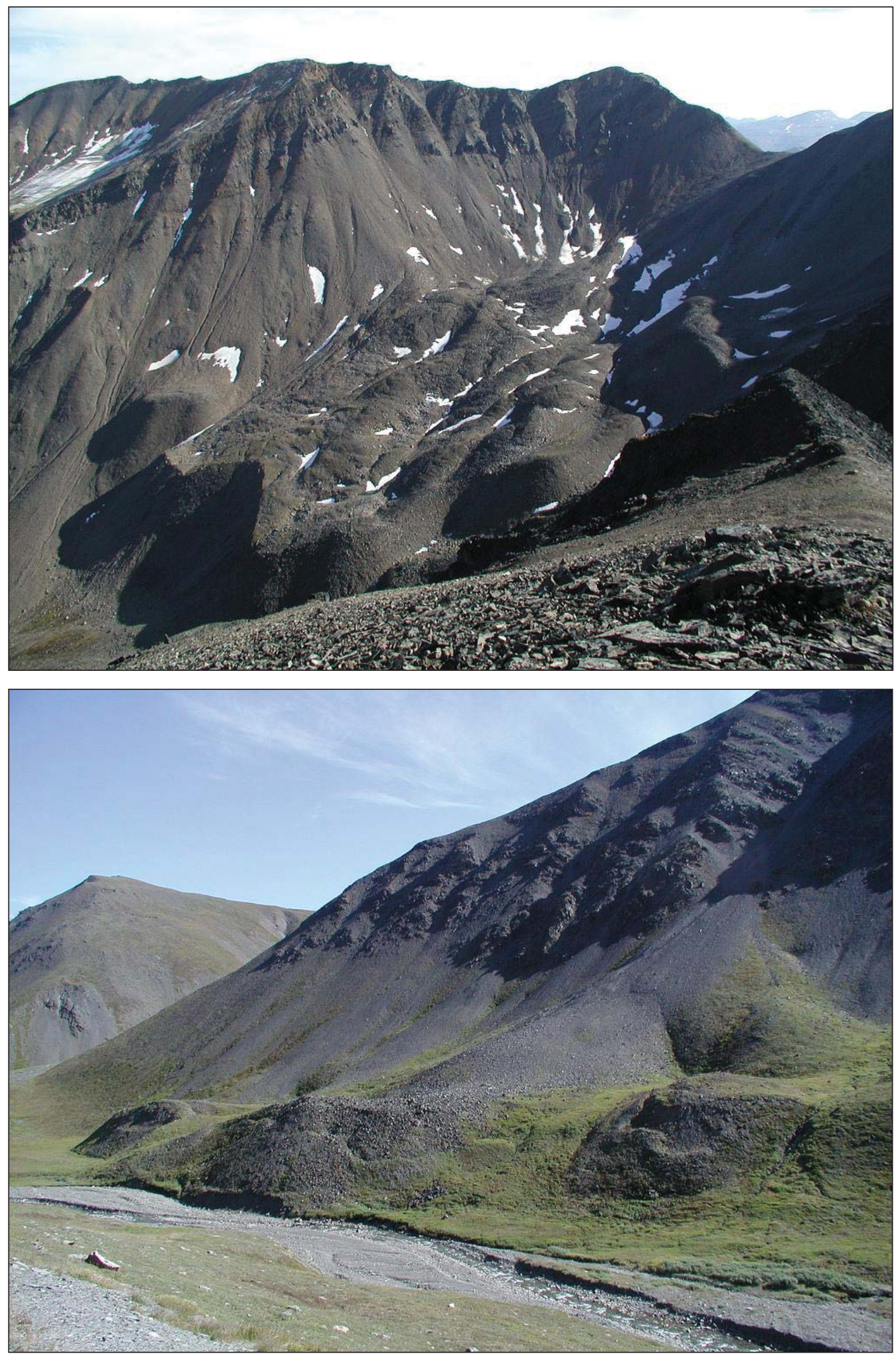

Figure 19. Rock glaciers in the Atigun Pass area. (Top) Pika Rock Glacier, a tongue-shaped rock glacier, lying in a cirque west of the pass (not visible from the road). (Bottom) Several lobate rock glaciers along the highway north of the pass. Photos courtesy of Atsushi Ikada. 


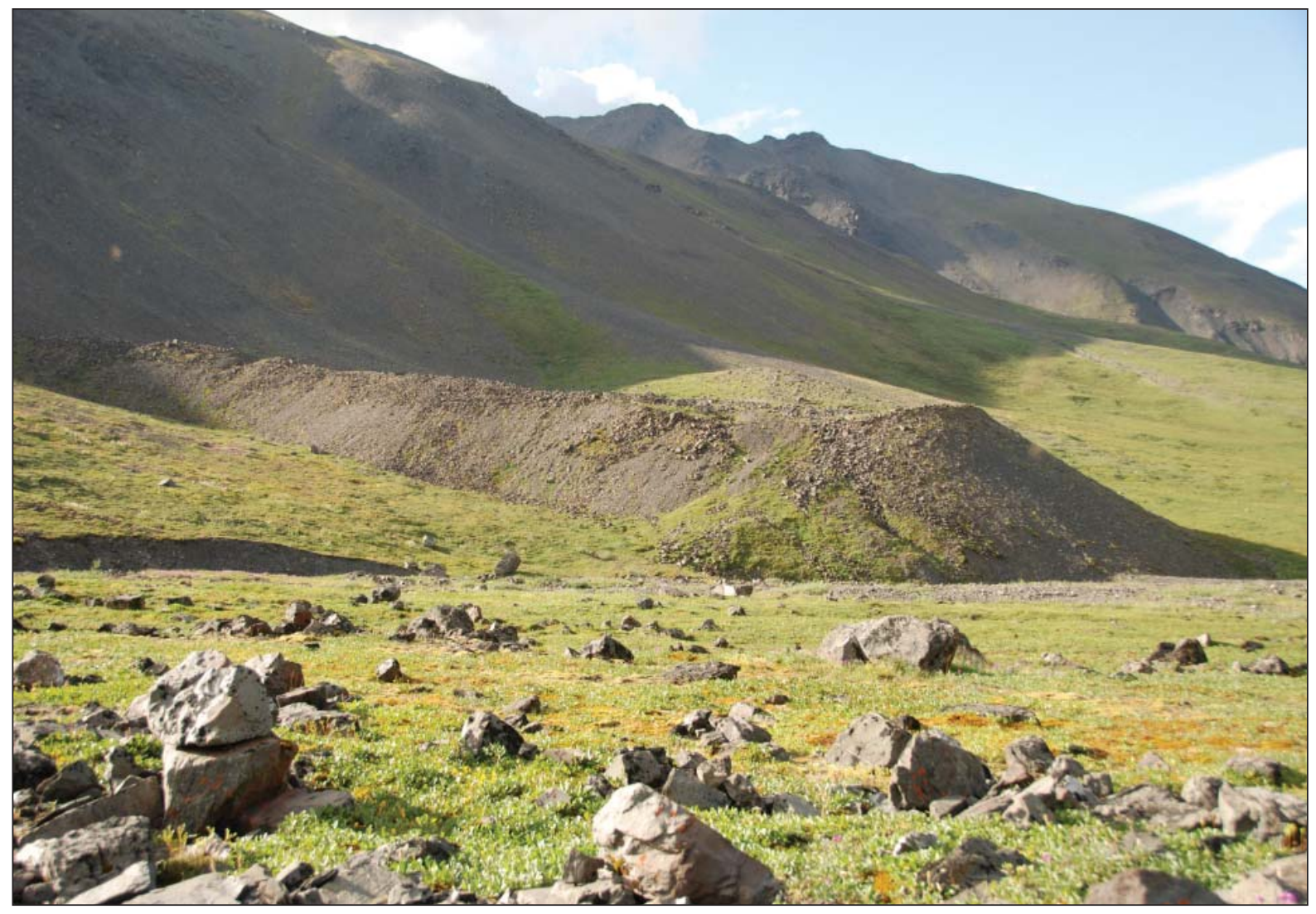

Figure 20. Lobate-shaped rock glacier at Milepost 246.7, Atigun Pass. Rock rubble on fan in foreground was deposited by slush flows. Photo by D.A. Walker.

geomorphic features, including talus cones, steep alpine fans, broad alluvial fans, and lateral moraines or kame terraces, are clearly visible along the bases of both valley walls, and many of these features are readily accessible from the Dalton Highway. Steep alpine fans in areas just north of here have been described and mapped by Kaye Everett (Brown and Kreig, 1983) and Hamilton (2003). Maps on p. 168, 172, and 174 in Brown and Kreig (1983) show the location of lobate rock glaciers, talus cones, debris cones, alluvial fans, kame terraces, and lateral moraine remnants within and north of the Atigun River Valley.

Talus consisting of coarse, angular, unsorted rock rubble has accumulated where rockfall is common. Talus forms steep debris cones at the bases of steep ravines or chutes, and broader aprons accumulate along the bases of steep cliffs.

Steep alpine fans (fig. 21) occur at the bases of chutes that commonly broaden upward into larger source areas. They are composed of coarse angular rubble mixed with variable amounts of finer debris. Their surfaces typically exhibit one or more channels bordered by ridgelike levees of rock rubble. Slope angles $\left(12-25^{\circ}\right)$ are intermediate between those of talus cones and alluvial fans.
Although formed commonly by slush flows during spring snowmelt period, large increments of debris are added at longer intervals during periods of exceptionally heavy summer rainstorms.

Alluvial fans are broader features with gentler surface slopes that contain larger amounts of subrounded stream gravel. Distributary channels that radiate down their surfaces developed as streams aggraded their beds and then shifted to new locations.

Kame terraces and lateral moraines are visible in places along the bases of both valley walls. Most have been heavily modified by slope failures and overriding alluvial and colluvial deposits. The kame terraces, formed of water-washed gravel, are most common where tributary valleys or gorges transported meltwater into positions along the margin of the main-valley glacier. The lateral moraines, composed of unsorted debris, occur where tributary glaciers joined the main glacier in Atigun Valley.

\section{Stop 17: Milepost D-246.7, Atigun River Valley debris slopes}

Many fans in upper mountain valleys are compound features, built by stream deposition during summers and 

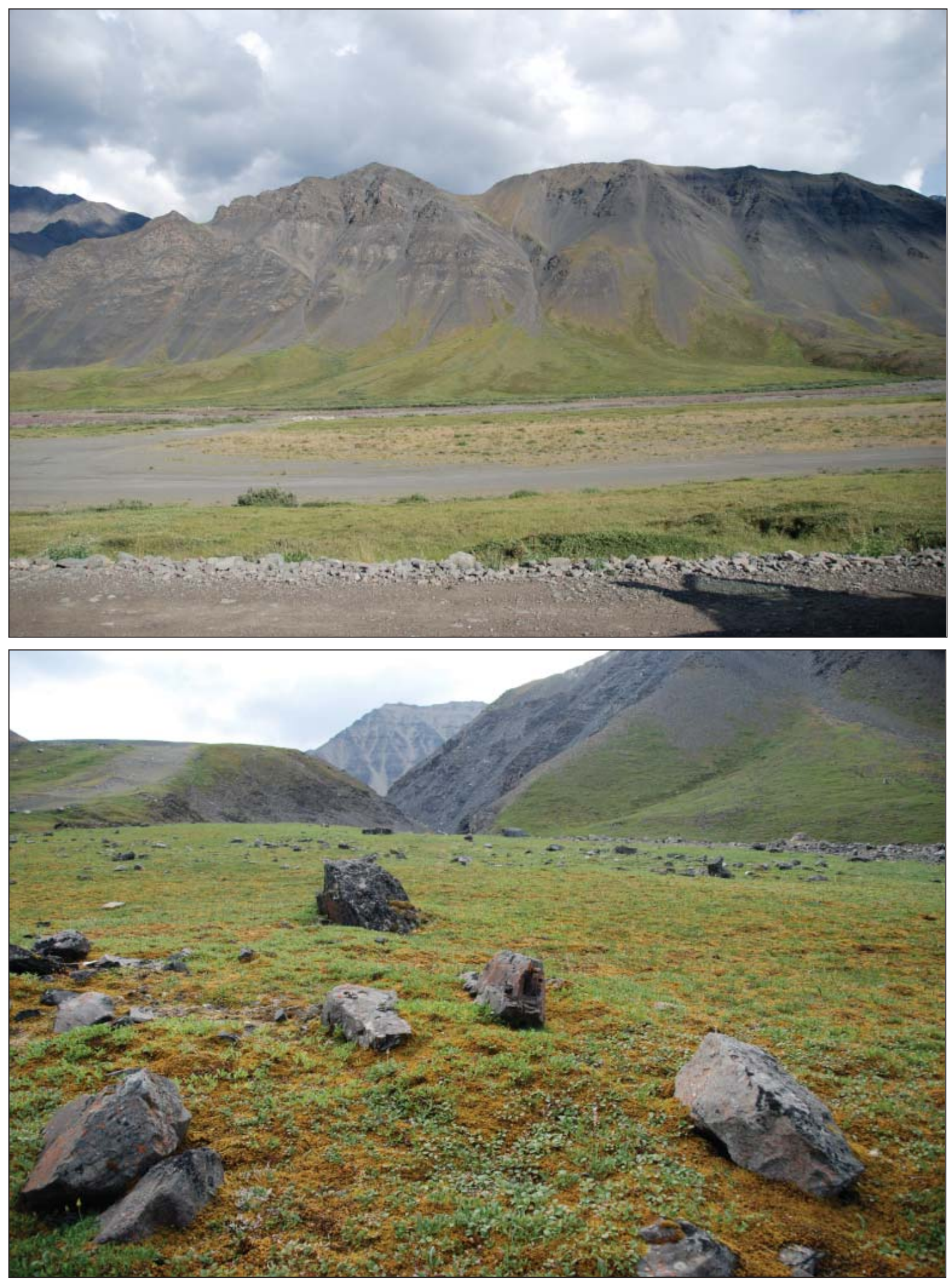

Figure 21. (Top) Steep, large alluvial fan on the east side of the road near the old Atigun Construction Camp. (Bottom) Semi-steep compound fan (alluvial, colluvial, alpine fan) is being built by mass wasting process. A slush-flow chute is just visible near the base of the hill to the right. Photo by D.A. Walker. 
intermittent slush flows in spring and occasional debris flows during periods of heavy rain. We will examine the surface of this fan and shallow incisions into it for evidence of these various formative processes. Several lobate rock glaciers can be seen from this location. Also see Brown and Kreig, 1983, p. 169.

\section{Stop 18: Milepost D-270, Pump Station 4}

Photo stop. Pump Station 4. A description of the pump station and the gas line used to power it are in Brown and Kreig (1983, p. 175).

\section{Stop 19: Milepost D-276, Galbraith Lake} Galbraith Lake nonsorted circles

Near Galbraith Lake, we will visit the soil study site of Chien Lu Ping, Gary Michaelson, Misha Kanevsky, and Yuri Shur (figs. 22, 23; tables 1, 2, for soil profile description and chemical and physical properties of the soils). The nonsorted circles in the Galbraith Lake deposits have formed in sandy soils that overlie clayey lacustrine sediments. The clayey mounds have been injected through frost cracks in the sandy sediments, and in places the circles are aligned along these cracks. Nonsorted circles on the Arctic coastal plain have very different properties and will be examined on Day 4 of the field trip.

\section{Aufeis deposit}

Aufeis (fig. 24) accumulates during the winter along stream and river valleys in arctic and subarctic environments. Aufeis forms by upwelling of river water behind ice dams, or by ground-water discharge. Successive overflow events can lead to aufeis accumulations that are several meters thick. Typically aufeis will melt out during summer and will form in the same place year after year (Hu and Pollard, 1997). A more detailed description of aufeis is in Brown and Kreig (1983, p. 14-17). Yoshikawa and others (2007) are quoted here.

"Most of the major aufeis fields in the Brooks Range originate at groundwater springs or seepage zones. For example, large aufeis fields are common along the north flank of the central and eastern Brooks Range, where thick limestone beds of the late Paleozoic Lisburne Group are exposed along valley walls. Subsurface water moves freely through solution passages deep within the limestone, and large quantities emerge as springs and seeps on valley
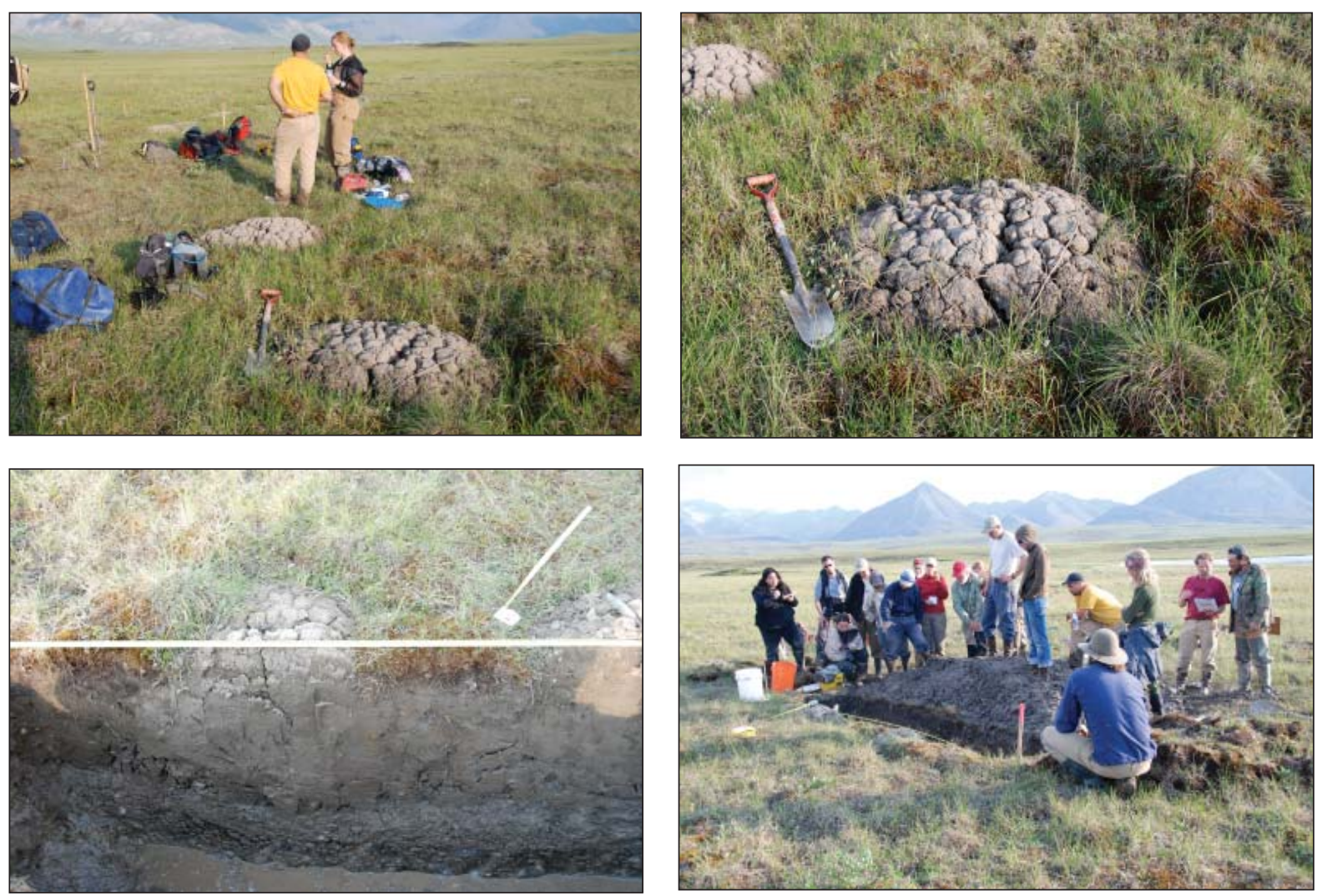

Figure 22. (Top) Nonsorted circles at Galbraith Lake. (Bottom) Galbraith Lake soil study site of Chien Lu Ping, Gary Michaelson, Misha Kanevsky, and Yuri Shur. Photos by D.A. Walker. 

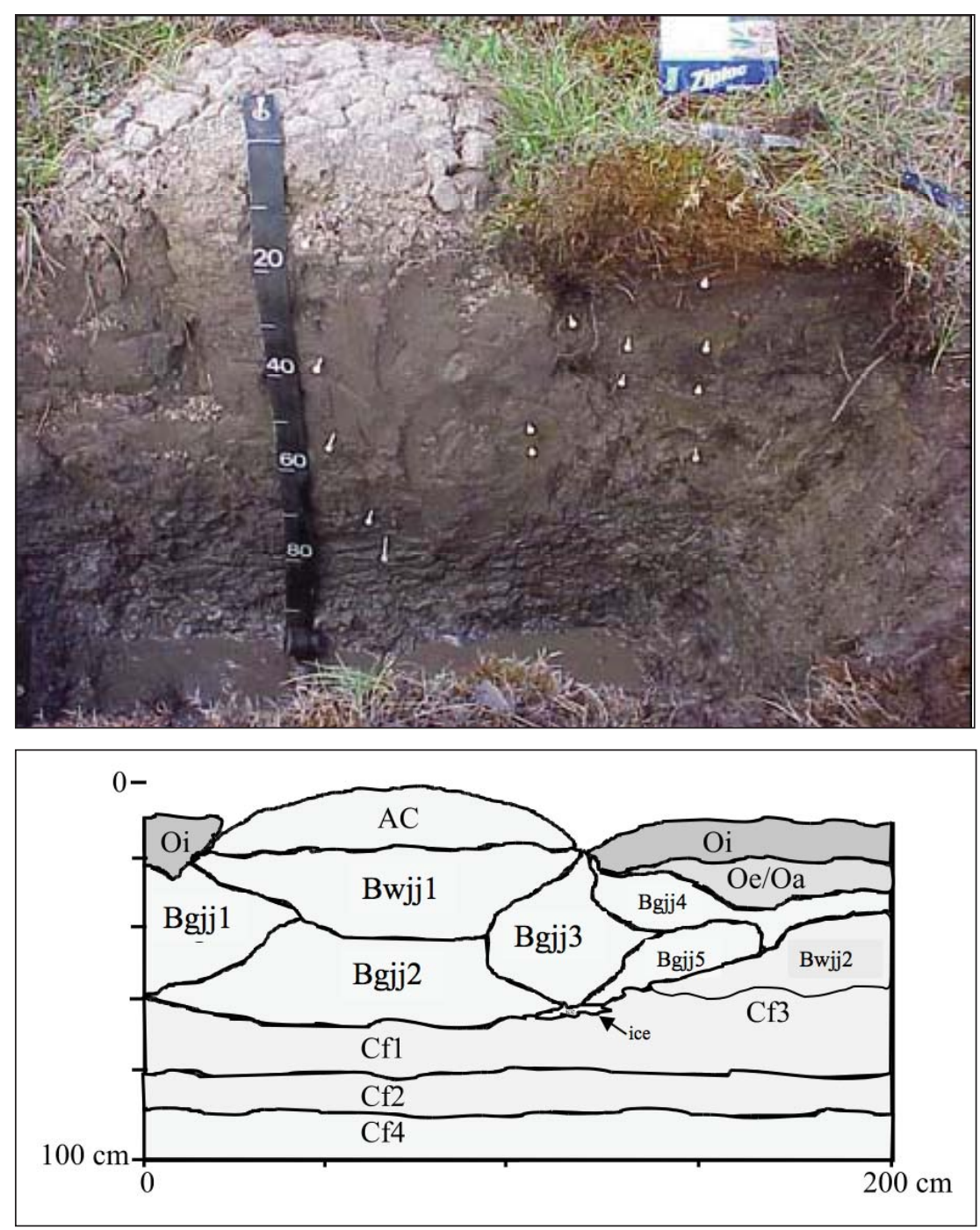

Figure 23. Soil profile for nonsorted circle at Galbraith Lake. Photo and drawing courtesy of Gary Michaelson.

floors throughout the winter months. Remote sensing techniques have been proven to be very valuable in investigating hydrological processes in remote arctic regions. Using satellite imagery, we have been able to quantify (1) aufeis distribution, (2) spring water temperature, (3) discharge volume, (4) relative age of spring formation, (5) aufeis historical extent, and (6) estimations of winter baseflow. In the Brooks Range of Alaska, many of the high discharge springs that provided water for the aufeis fields are generally located near $600 \mathrm{~m}$ [above sea level] in limestone areas with glacial morphology and an associated fault system. Also, many of the springs survived at least the previous glaciation (perhaps more). The results from analyses of carbonate deposit distributions indicate that the past discharge amounts and water temperatures might be very similar to today.
Aufeis is an important surface storage component in the hydrologic cycle of arctic watersheds. Aufeis formations represent at least one-third of the cumulative annual base flow. The source of the winter discharge is mainly spring water from intra and subpermafrost aquifers. The source of the spring water for the aufeis formations in the eastern Brooks Range in Alaska is from recharge areas substantially outside of the watershed (south side of Brooks Range). Aufeis accumulates throughout the winter, reaching a peak in late April/early May and meltwater from the aufeis is released mainly in June and July (with some in August, the amount depending upon the weather for that month). Climatic warming in the Arctic will affect many of the components of the hydrological regime. However, formation and melting of aufeis is less sensitive to climatic change, but very sensitive to 
Table 1. Galbraith Lake nonsorted circle pedon description.

\author{
Geomorphic position: Lake basin \\ Galbraith Lake Frost Boil Study Site (07/21/2001) \\ Soil survey area \#: 185 \\ Physiography: Brooks Range Foothills \\ Major: Valley Local: lake basin \\ Lat. $68^{\circ} 28^{\prime} 54^{\prime \prime} \mathrm{N}$; Long: $149^{\circ} 28^{\prime} 34^{\prime \prime} \mathrm{W}$
}

\author{
Slope characteristics information \\ Slope $0 \%$ aspect: NA \\ Horizontal shape: slightly hummocky \\ Vertical shape: slightly hummocky \\ Classification: Fine, mixed, pergelic Ruptic \\ Histoturbel (Turbic Histic Cryosol)
}

\section{Vegetative information \\ Plant name: Eriophorum triste, Betula nana, Salix arctica, S. rotundifolia, Dryas \\ integrifolia, Tomentypnum nitens, Polygonum sp., Arctous rubra, Carex membranaceae, Cetraria cucullata, Tofieldia pusilla, Rhododendron lapponicum, Eriophorum vaginatum. \\ Described by: C.L. Ping, C.A. Stiles, G. Michaelson, P.P. Overduin, and J.M. Kimble \\ INTERCIRCLE

\begin{tabular}{|c|c|}
\hline Oi & $\begin{array}{l}0 \text { to } 20 \mathrm{~cm} \text {; dark brown }(7.5 \text { YR } 3 / 3) \text {, peat, many fine few medium roots, abrupt wavy } \\
\text { boundary ( } 1 \text { to } 8)\end{array}$ \\
\hline $\mathrm{Oe}$ & $\begin{array}{l}20 \text { to } 27 \mathrm{~cm} \text {; very dark brown ( } 7.5 \mathrm{YR} 2.5 / 2) \text {, mucky peat, weak medium granular, very friable, } \\
\text { nonplastic nonsticky, many fine few medium roots, abrupt irregular boundary ( } 2 \text { to } 5 \mathrm{~cm})\end{array}$ \\
\hline Bwjj2 & $\begin{array}{l}27 \text { to } 48 \mathrm{~cm} \text {; very dark grayish brown (10YR } 3 / 2) \text { and dark grayish brown }(10 \mathrm{YR} 4 / 2,30 \%) \\
\text { fine sandy loam; weak medium platy structure; friable, slightly sticky slightly plastic; many } \\
\text { very fine and fine roots; abrupt smooth boundary ( } 0 \text { to } 18 \mathrm{~cm})\end{array}$ \\
\hline $\mathrm{Cf} 3$ & $\begin{array}{l}48 \text { to } 65 \mathrm{~cm} \text {; very dark gray ( } 10 \mathrm{YR} 3 / 1) \text { clay; strong medium reticulate structure; extremely } \\
\text { firm, sticky very plastic; } 50-60 \% \text { ice; clear wavy boundary }\end{array}$ \\
\hline $\mathrm{Wf} / \mathrm{Cf} 4$ & $\begin{array}{l}65 \text { to } 100 \mathrm{~cm} \text {; very dark gray ( } 10 \mathrm{YR} 4 / 1) \text { clay; strong medium reticulate (ataxitic) structure; } \\
\text { very firm, sticky very plastic; } 75 \% \text { ice }\end{array}$ \\
\hline
\end{tabular}

CIRCLE

ACjj 0 to $18 \mathrm{~cm}$; dry: dark grayish brown (2.5Y 4/2); moist: very dark grey (2.5Y $3 / 1)$ clay; strong medium columnar structure, extremely firm, very sticky, very plastic, clear smooth boundary (0 to $18 \mathrm{~cm})$

Bwjj1 18 to $41 \mathrm{~cm}$; dark gray $(2.5 \mathrm{Y} 4 / 1)$ clay, moderate medium platy structure; very firm, very sticky, very plastic, common very fine, fine and few medium roots; clear smooth boundary $(0$ to $22 \mathrm{~cm}$ )

Bgjj1 20 to $52 \mathrm{~cm}$; dark grey (2.5Y 4/1) clay; $30 \%$ Fe-concentrations (10YR 4/3); massive; saturated; very sticky, very plastic, few very fine and fine roots; clear irregular boundary ( 0 to $32 \mathrm{~cm})$

Bgji2 52 to $65 \mathrm{~cm}$; dark brown (10YR 3/2) clay; weak fine platy structure; very firm, very sticky, very plastic, few fine roots, clear irregular boundary $(0$ to $20 \mathrm{~cm})$

Bgjj3 20 to $60 \mathrm{~cm}$; very dark grayish brown (2.5Y 3/2) clay; massive; sticky very plastic; common fine roots; clear irregular boundary $(0$ to $40 \mathrm{~cm})$

Bgjj4 25 to $40 \mathrm{~cm}$; dark grayish brown (2.5Y 4/2) clay; massive (saturated); sticky very plastic; many fine roots; clear irregular boundary (0 to $15 \mathrm{~cm})$

Bgjj5 40 to $48 \mathrm{~cm}$; dark grayish brown (2.5Y 4/2) and dark gray (2.5Y 4/1) clay; massive (saturated); sticky very plastic; few very fine and fine roots; clear irregular boundary ( 0 to 10 $\mathrm{cm})$

Cf1 65 to $75 \mathrm{~cm}$; very dark gray (10YR 3/1) clay; strong medium reticulate (ataxitic) structure; soil $3-5 \mathrm{~mm}$ and ice $2-3 \mathrm{~mm}$ thick, $40 \%$ ice; very firm (frozen); sticky very plastic, abrupt smooth boundary

Cf2 75 to $88 \mathrm{~cm}$; dark grey (2.5Y 4/1) clay; strong thick reticulate (ataxitic) structure; soil 5-10 $\mathrm{mm}$ and ice $2-5 \mathrm{~mm}$ thick; very firm (frozen); sticky very plastic

Cf4 88 to $100 \mathrm{~cm}$; very dark gray (10YR 4/1) clay; strong medium reticulate (ataxitic) structure; very firm, sticky very plastic; $75 \%$ ice 
the source spring water properties such as the temperature and the volume (discharge)" (Yoshikawa and others, 2007).

Stop 20: Milepost D-286, Toolik Field Station

We will spend the next two evenings at Toolik Field Station (TFS), located in the northern foothills of the Brooks Range on the southeast shore of Toolik Lake $\left(68^{\circ} 38^{\prime} \mathrm{N}, 149^{\circ} 36^{\prime} \mathrm{W}\right.$, elevation $720 \mathrm{~m}[2,360 \mathrm{ft}], 254 \mathrm{~km}$ [160 mi] north of the Arctic Circle). This location affords access to three major physiographic provinces of Alaska: the Brooks Range, the Arctic Foothills and the Arctic Coastal Plain. TFS also serves as a base for researchers working along the ecological transect connecting tundra to boreal forest along the Dalton Highway between
Prudhoe Bay and Fairbanks. The station is operated year-round and administered by the Institute of Arctic Biology at the University of Alaska Fairbanks (Brown and Kreig, 1983, p. 179).

The field station was established in 1975 at the north end of the lake; it was moved to its present site in 1982-83. It has a 30-year history of supporting large and diverse arctic research and monitoring programs, and the focus has been on long-term, intensive, and processbased ecological research since the beginning. Research at TFS has produced some of the longest continuous records of a wide range of environmental variables in the North American Arctic. Intensive research at TFS into the mechanisms underlying plant and animal adaptations to the environment and the controls over ecosystem

Table 2. Galbraith Lake nonsorted-circle site soil chemical and physical properties.

\begin{tabular}{|c|c|c|c|c|c|c|c|c|c|c|c|c|c|c|c|c|}
\hline \multirow{2}{*}{$\begin{array}{c}\text { Soil } \\
\text { Horizon }\end{array}$} & \multirow[b]{2}{*}{$\begin{array}{c}\text { depth } \\
\text { cm }\end{array}$} & \multicolumn{2}{|l|}{ 1:1 } & \multirow{2}{*}{$\begin{array}{c}\text { Extr. } \\
\mathrm{NH}_{4}-\mathrm{N} \\
\mathrm{mg} \mathrm{kg}^{-1}\end{array}$} & \multirow{2}{*}{$\begin{array}{c}\text { Extr. } \\
\mathrm{NO}_{3}-\mathrm{N} \\
\mathrm{mg} \mathrm{kg}^{-1}\end{array}$} & \multirow{2}{*}{$\begin{array}{c}\text { Extr. } \\
P \\
\text { mg kg }^{-1}\end{array}$} & \multirow[b]{2}{*}{ CEC } & \multirow[b]{2}{*}{$\mathrm{Ca}$} & \multirow[b]{2}{*}{ Mg } & \multirow[b]{2}{*}{$\mathrm{Na}$} & \multirow[b]{2}{*}{$\mathbf{K}$} & \multirow{2}{*}{$\begin{array}{c}\text { Base } \\
\text { Sat. } \\
\% \\
\end{array}$} & \multirow{2}{*}{$\begin{array}{c}\text { Extr. } \\
\mathrm{H}^{+} \\
\text {me } 100 \mathrm{~g}^{-1} \\
\end{array}$} & \multicolumn{3}{|c|}{ Oxalate Extractable } \\
\hline & & pH & $\begin{array}{c}\text { E.C } \\
\text { ds } \mathrm{cm}^{-1} \\
\end{array}$ & & & & & & & & & & & $\begin{array}{l}\mathrm{Fe} \\
\%\end{array}$ & $\begin{array}{l}\mathrm{Si} \\
\% \\
\end{array}$ & $\begin{array}{l}\text { Al } \\
\%\end{array}$ \\
\hline Oe & $0-6$ & 7.40 & 0.40 & 6 & 2 & 20 & 62 & 61 & 1.73 & 0.05 & 0.57 & 100 & 11.68 & 0.79 & 0.10 & 0.15 \\
\hline $\mathrm{Oe} / \mathrm{Oa}$ & $6-16$ & 6.92 & 0.29 & $<1$ & $<1$ & 4 & 33 & 21 & 0.83 & 0.02 & 0.12 & 68 & 9.86 & 1.49 & 0.15 & 0.20 \\
\hline Oajj & $16-22$ & 7.56 & 0.27 & $<1$ & $<1$ & 5 & 17 & 22 & 0.61 & 0.03 & 0.06 & 100 & 3.08 & 0.64 & 0.09 & 0.14 \\
\hline Acjj & $0-18$ & 7.94 & 0.25 & $<1$ & $<1$ & 3 & 15 & 20 & 0.79 & 0.03 & 0.20 & 100 & 3.97 & 1.72 & 0.21 & 0.30 \\
\hline Bwjj1 & $18-43$ & 7.89 & 0.29 & $<1$ & $<1$ & 3 & 14 & 21 & 0.70 & 0.03 & 0.20 & 100 & 5.95 & 1.65 & 0.20 & 0.29 \\
\hline Bwjj2 (sand) & $22-38$ & 7.92 & 0.27 & $<1$ & $<1$ & 2 & 9 & 24 & 0.28 & 0.03 & 0.07 & 100 & 1.46 & 0.71 & 0.08 & 0.12 \\
\hline Bgjj1 & $20-55$ & 7.87 & 0.29 & 1 & $<1$ & 3 & 14 & 16 & 0.58 & 0.02 & 0.20 & 100 & 8.87 & 2.16 & 0.25 & 0.35 \\
\hline Bgjj2 & $38-70$ & 7.92 & 0.31 & $<1$ & $<1$ & 3 & 22 & 16 & 0.44 & 0.02 & 0.19 & 76 & 4.38 & 1.90 & 0.23 & 0.32 \\
\hline Bgjj3 & $20-62$ & 7.84 & 0.33 & 1 & $<1$ & 3 & 22 & 14 & 0.43 & 0.03 & 0.20 & 64 & 8.35 & 2.16 & 0.27 & 0.36 \\
\hline Bgjj4 & $20-45$ & 7.86 & 0.31 & $<1$ & $<1$ & 3 & 19 & 17 & 0.70 & 0.03 & 0.20 & 93 & 7.20 & 1.99 & 0.25 & 0.34 \\
\hline Bgjj5 & $38-60$ & 7.92 & 0.29 & $<1$ & $<1$ & 3 & 16 & 16 & 0.44 & 0.03 & 0.19 & 100 & 6.88 & 2.12 & 0.25 & 0.34 \\
\hline Cf1 & $53-75$ & 7.86 & 0.33 & $<1$ & 1 & 1 & 15 & 13 & 0.36 & 0.02 & 0.21 & 92 & 7.20 & 2.10 & 0.24 & 0.33 \\
\hline $\mathrm{Cf} 2$ & $75-88$ & 8.00 & 0.40 & 3 & $<1$ & 2 & 14 & 18 & 0.53 & 0.02 & 0.21 & 100 & 6.26 & 2.12 & 0.24 & 0.35 \\
\hline Cf3 & $53-75$ & 8.12 & 0.42 & 3 & $<1$ & 2 & 10 & 19 & 0.39 & 0.02 & 0.13 & 100 & 5.72 & 1.47 & 0.17 & 0.24 \\
\hline Cf3 & - & 8.07 & 0.46 & 1 & $<1$ & 2 & 20 & 21 & 0.42 & 0.02 & 0.15 & 100 & 4.69 & 1.49 & 0.18 & 0.26 \\
\hline Cf4 & $88-100+$ & 8.10 & 0.40 & 2 & 1 & 2 & 13 & 14 & 0.59 & 0.01 & 0.19 & 100 & 7.19 & 2.02 & 0.23 & 0.32 \\
\hline Cf4 & - & 8.08 & 0.42 & 5 & 1 & 2 & 20 & 14 & 0.56 & 0.02 & 0.17 & 78 & 4.38 & 1.82 & 0.20 & 0.28 \\
\hline
\end{tabular}

Table 2. Galbraith Lake nonsorted-circle site soil chemical and physical properties (continued).

\begin{tabular}{|c|c|c|c|c|c|c|c|c|c|c|c|c|c|c|c|c|c|}
\hline \multirow{3}{*}{$\begin{array}{c}\text { Soil } \\
\text { Horizon }\end{array}$} & \multicolumn{3}{|c|}{ Citrate-Dithionite Extr. } & \multicolumn{2}{|c|}{ Na-Pyrophosphate } & \multirow{3}{*}{$\begin{array}{c}\text { depth } \\
\text { cm }\end{array}$} & \multirow{3}{*}{$\begin{array}{c}\text { Bulk } \\
\text { Density } \\
\mathrm{g} \mathrm{cm}^{-1}\end{array}$} & \multirow{3}{*}{$\begin{array}{c}\text { USDA } \\
\text { Texture }\end{array}$} & \multicolumn{3}{|c|}{$<2 \mathrm{~mm}_{\mathrm{wt}}$} & \multirow{3}{*}{$\begin{array}{c}>2 \mathrm{~mm} \\
\text { vol. } \\
\%\end{array}$} & \multicolumn{2}{|c|}{ Total } & \multirow{3}{*}{$\begin{array}{c}\text { Water } \\
\text { Content } \\
\% \text { vol. }\end{array}$} & \multirow{3}{*}{$\begin{array}{c}\text { IC } \\
\%\end{array}$} & \multirow{3}{*}{$\begin{array}{c}\text { OC } \\
\%\end{array}$} \\
\hline & $\mathbf{F e}$ & Al & Mn & $\mathbf{F e}$ & Al & & & & Clay & Silt & Sand & & C & $\mathbf{N}$ & & & \\
\hline & $\%$ & $\%$ & $\%$ & $\%$ & $\%$ & & & & $\%$ & $\%$ & $\%$ & & $\%$ & $\%$ & & & \\
\hline Oe & 1.05 & 0.08 & 0.10 & 0.11 & $<0.01$ & $0-6$ & 0.16 & PEAT & na & na & na & 0.58 & 10.96 & 0.58 & 36 & 0.0 & 10.96 \\
\hline $\mathrm{Oe} / \mathrm{Oa}$ & 1.21 & 0.07 & 0.04 & 0.33 & 0.01 & $6-16$ & 0.75 & SL & 11.6 & 34.8 & 53.6 & 0.11 & 6.26 & 0.39 & 74 & 0.0 & 6.26 \\
\hline Oajj & 0.47 & 0.05 & $<0.01$ & 0.13 & $<0.01$ & $16-22$ & 1.00 & SL & 12 & 24.8 & 63.2 & 0.29 & 4.02 & 0.16 & 64 & 1.0 & 2.98 \\
\hline Acjj & 1.48 & 0.09 & 0.02 & 0.07 & $<0.01$ & $0-18$ & 1.48 & $\mathrm{C}$ & 50 & 30.8 & 19.2 & 0.58 & 2.29 & 0.08 & 28 & 0.6 & 1.70 \\
\hline Bwjj1 & 1.51 & 0.09 & 0.02 & 0.07 & $<0.01$ & $18-43$ & 1.73 & $\mathrm{C}$ & 48 & 30.8 & 21.2 & 0.49 & 2.36 & 0.09 & 40 & 0.6 & 1.75 \\
\hline Bwjj2 (sand) & 0.86 & 0.06 & 0.01 & 0.09 & $<0.01$ & $22-38$ & 1.35 & SL & 16 & 16.8 & 67.2 & 0.49 & 4.05 & 0.15 & 37 & 1.0 & 3.00 \\
\hline Bgij1 & 1.64 & 0.10 & 0.03 & 0.06 & $<0.01$ & $20-55$ & 1.51 & $\mathrm{C}$ & 52 & 26.8 & 21.2 & 0.23 & 2.21 & 0.08 & 42 & 0.6 & 1.64 \\
\hline Bgij2 & 1.45 & 0.09 & 0.03 & 0.07 & $<0.01$ & $38-70$ & 1.57 & $\mathrm{C}$ & 52 & 26.8 & 21.2 & 0.20 & 2.44 & 0.11 & 38 & 0.6 & 1.81 \\
\hline Bgij3 & 1.65 & 0.10 & 0.02 & 0.05 & $<0.01$ & $20-62$ & 2.03 & $\mathrm{C}$ & 54 & 28.8 & 17.2 & 0.33 & 2.08 & 0.06 & 53 & 0.5 & 1.54 \\
\hline Bgij4 & 1.57 & 0.11 & 0.03 & 0.07 & $<0.01$ & $20-45$ & 1.54 & $\mathrm{C}$ & 52 & 28.8 & 19.2 & 0.73 & 2.20 & 0.07 & 52 & 0.6 & 1.63 \\
\hline Bgjj5 & 1.63 & 0.10 & 0.03 & 0.06 & $<0.01$ & $38-60$ & 1.70 & $\mathrm{C}$ & 54 & 26.8 & 19.2 & 0.31 & 2.12 & 0.10 & 44 & 0.5 & 1.57 \\
\hline Cf1 & 1.50 & 0.08 & 0.04 & 0.21 & $<0.01$ & $53-75$ & 1.32 & $\mathrm{C}$ & 52 & 26.8 & 21.2 & 0.55 & 2.28 & 0.08 & 50 & 0.6 & 1.69 \\
\hline $\mathrm{Cf} 2$ & 1.51 & 0.07 & 0.04 & 0.34 & $<0.01$ & $75-88$ & 0.96 & $\mathrm{C}$ & 48 & 28.8 & 23.2 & 0.48 & 2.46 & 0.08 & 45 & 0.6 & 1.82 \\
\hline Cf3 & 1.17 & 0.06 & 0.03 & 0.27 & $<0.01$ & $53-75$ & 0.77 & $\mathrm{CL}$ & 35.6 & 26.4 & 38 & 0.15 & 3.14 & 0.10 & 41 & 0.8 & 2.33 \\
\hline $\mathrm{Cf} 3$ & 1.15 & 0.06 & 0.03 & 0.26 & 0.01 & - & 0.77 & $\mathrm{CL}$ & 35.6 & 26.4 & 38 & 0.25 & 3.24 & 0.13 & 43 & 0.8 & 2.40 \\
\hline Cf4 & 1.37 & 0.07 & 0.04 & 0.29 & 0.01 & $88-100+$ & -0.35 & $\mathrm{C}$ & 47.6 & 30.4 & 22 & 0.15 & 2.43 & 0.10 & 42 & 0.6 & 1.80 \\
\hline Cf4 & 1.28 & 0.06 & 0.04 & 0.31 & $<0.01$ & - & 0.35 & $\mathrm{C}$ & 43.6 & 26.4 & 30 & 0.17 & 2.72 & 0.09 & 29 & 0.7 & 2.02 \\
\hline
\end{tabular}

Selected chemical and physical properties of the Galbraith Lake, frost boil soil profile (Sampled 07/21/01), 68 $28^{\prime} 54^{\prime \prime}{ }^{\prime}, 149^{\circ} 28^{\prime} 0.784^{\prime \prime} \mathrm{W}$ 


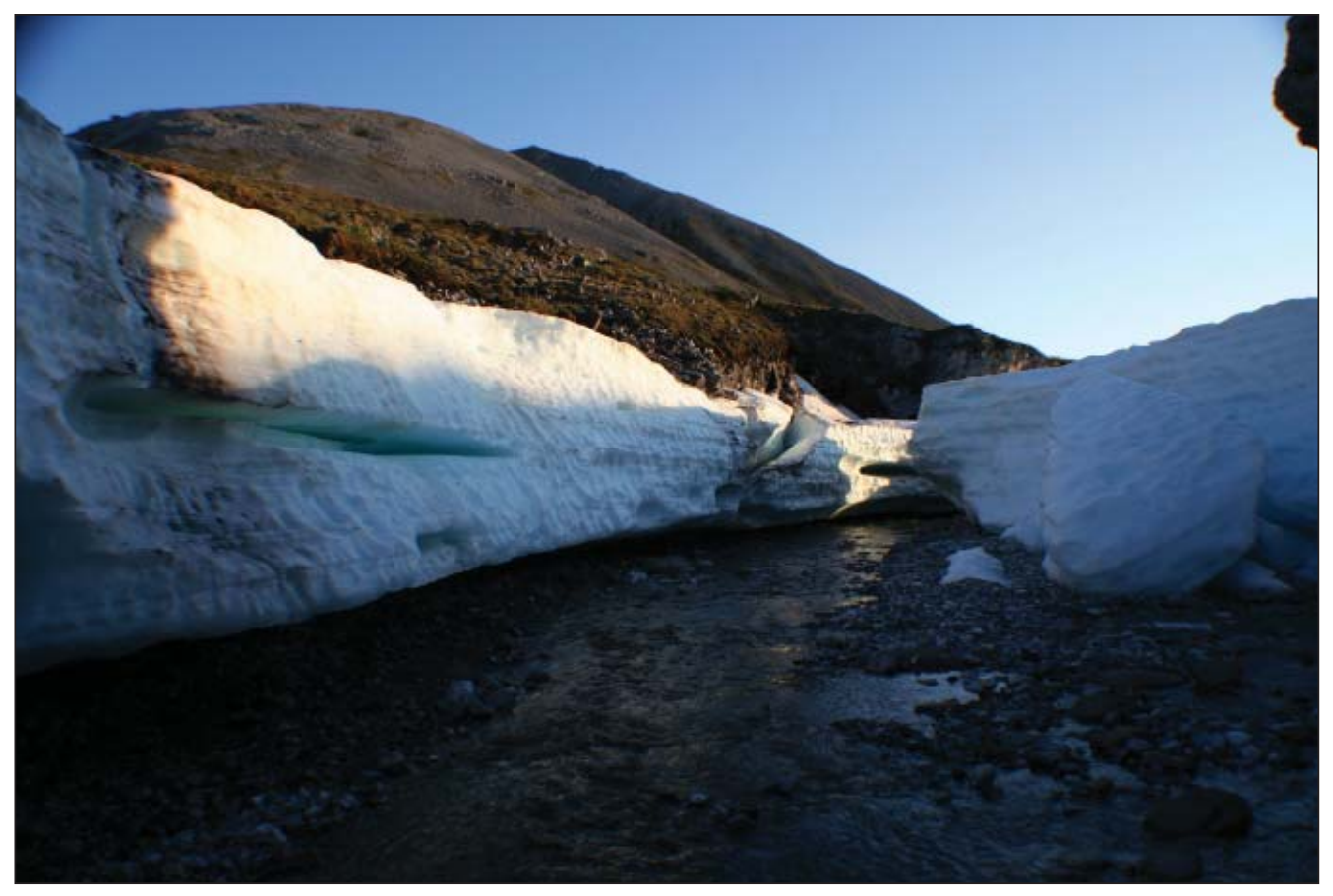

Figure 24. Aufeis deposit at Galbraith Lake.

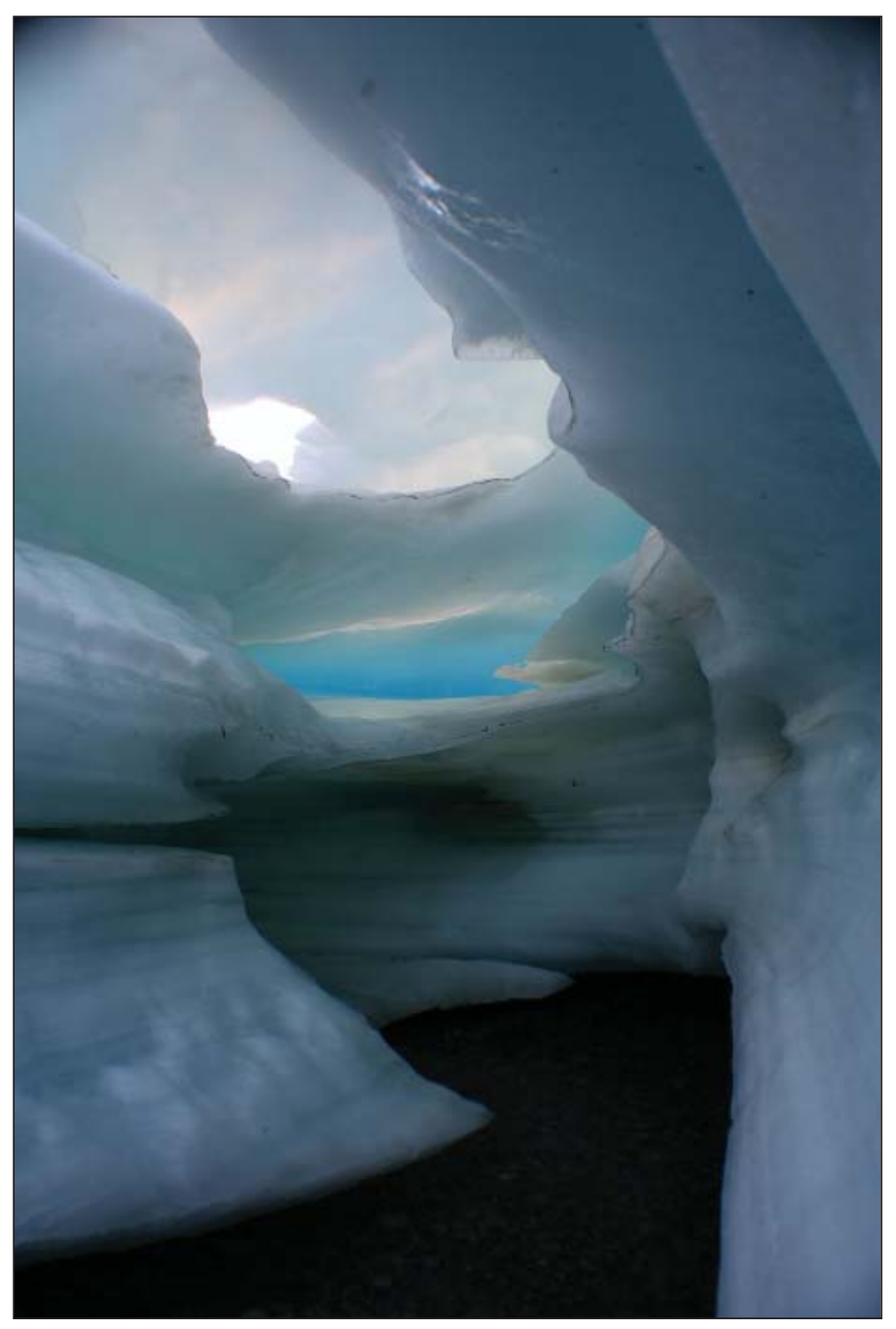
Photos by I. Timling. 
processing of carbon and nutrients has been critical in developing an understanding of how and why arctic ecosystems will change in an altered environment.

Toolik Field Station is the site of the NSF-sponsored Arctic Long-Term Ecological Research (LTER) program, begun in 1987, and administered by the Ecosystem Center of the Marine Biological Laboratory at Woods Hole, MA. The Arctic LTER program has maintained integrated research and education programs on the structure and function of nearby aquatic and terrestrial environments, has sustained collaborations among many of the highly productive scientists that originated ecological research in northern Alaska, and has trained many of the next generation of Arctic scientists. Currently, 14 universities and institutions contribute scientists to the Arctic LTER.

The Kuparuk River, Imnavait Creek, and other adjacent watersheds to the east of TFS have been the focus of long-term hydrologic and climate studies on the North Slope of Alaska. These studies were begun in 1985 by the Water and Environmental Research Center (WERC) at the University of Alaska Fairbanks. The WERC now intends to extend these studies into a long-term hydrological observatory, with logistical support from TFS, which has also been recommended for further development as part of a large effort in the Arctic research community to plan and coordinate development of facilities (Schlosser and others, 2003). Toolik Lake has been selected as the core tundra site for the National Ecological Observatory Network (NEON), and also participates in the Arctic Observatory Network (AON), through carbon flux towers based at Imnavait Creek. It is the only site in the U.S. where LTER, NEON, and AON intersect.

\section{DAY 3}

Overview: Today will be spent in the vicinity of Toolik Field Station. The focus of the day will be to examine the various glacial surfaces in the local area and how the history of these landscapes affects the ecology and permafrost conditions. In this cold region, landscape evolution proceeds much more slowly than in temperate regions so that differences in geomorphology, soils, and vegetation are evident on surfaces spanning hundreds of thousands of years. We will examine middle and late Pleistocene glacial surfaces. In the morning we will first visit the Itkillik glacial limit at the divide between the Toolik Lake region and the Kuparuk watershed, where much of the LTER stream research is being conducted. We will then go to the Imnavait Creek watershed, where research is being conducted on a surface that was last glaciated during the middle Pleistocene. In the afternoon we will return to Toolik Field Station and examine characteristics of the late Pleistocene glacial landscapes in the immediate vicinity of the camp. After dinner, Donie Brett-Harte and personnel from TFS will give an overview of the science being conducted at the field station.

\section{Stop 21: Milepost D-288, overlook of Itkillik glacial surfaces}

The Toolik Lake region is situated in close proximity to several major late Cenozoic glacial surfaces (Hamilton, 1986). These surfaces have not been altered by anthropogenic influences, so the region is an excellent laboratory to examine the effects of geological processes on ecosystem function. Glacial deposits of the same age exist on the south slopes of the Brooks Range as on the north side, but the differently-aged surfaces are difficult to see because many of the glacial features are masked by trees.

At this stop, on the broad hill east of the TFS, the road crosses the outer limit of a lateral moraine of Itkillik age. The margin of the Itkillik drift sheet is sharply defined by abrupt contrasts in soil, vegetation, drainage, and relief. To the east the broad, rolling, tussock-tundra covered ridges of Sagavanirktok age (figs. 25, 29) contrast sharply with the steeper, drier, more irregular, bouldery moraines at the Itkillik ice limit (fig. 28; table 4).

The complex topography of the Toolik Lake region was constructed by glaciers that flowed into the region during three major glacial episodes. Local glacial deposits within the Toolik Lake region are assigned to the Sagavanirktok (middle Pleistocene), and to the Itkillik I and Itkillik II (late Pleistocene) glaciations of the central Brooks Range glacial succession (Detterman and others, 1958). The Sagavanirktok glaciation consisted of several separate glacial events dating broadly from middle Quaternary time (about 780,000 to $125,000 \mathrm{yr}$ BP). During the initial (maximum) advances, large valley glaciers flowed north along the Itkillik River, Sagavanirktok River, and Kuparuk River drainages. Most of the upper Kuparuk River watershed, including the Imnavait Creek watershed, is on drifts of older Sagavanirktok-age deposits. The surfaces of the Sagavanirktok River glaciation have massive, gently-sloping moraines trending south-southeast to north-northwest that rise about $100 \mathrm{~m}$ $(330 \mathrm{ft})$ from the valley bottoms to the crests (Hamilton, 1986) (fig. 29). These moraines are well represented in the Imnavait Creek watershed. The hills formed by these moraines are rounded by gelifluction and heavy loess cover, and are topped with $20-40 \mathrm{~cm}$ (8-16 in) of peat. Scattered glacial erratics protrude up to $1 \mathrm{~m}$ (40 in) above the tundra surface.

Itkillik I glaciers abutted divides west, east, and south of the upper Kuparuk drainage, but overflowed those divides only locally. The subsequent Itkillik II glaciers advanced between about 25,000 and 11,500 radiocarbon 


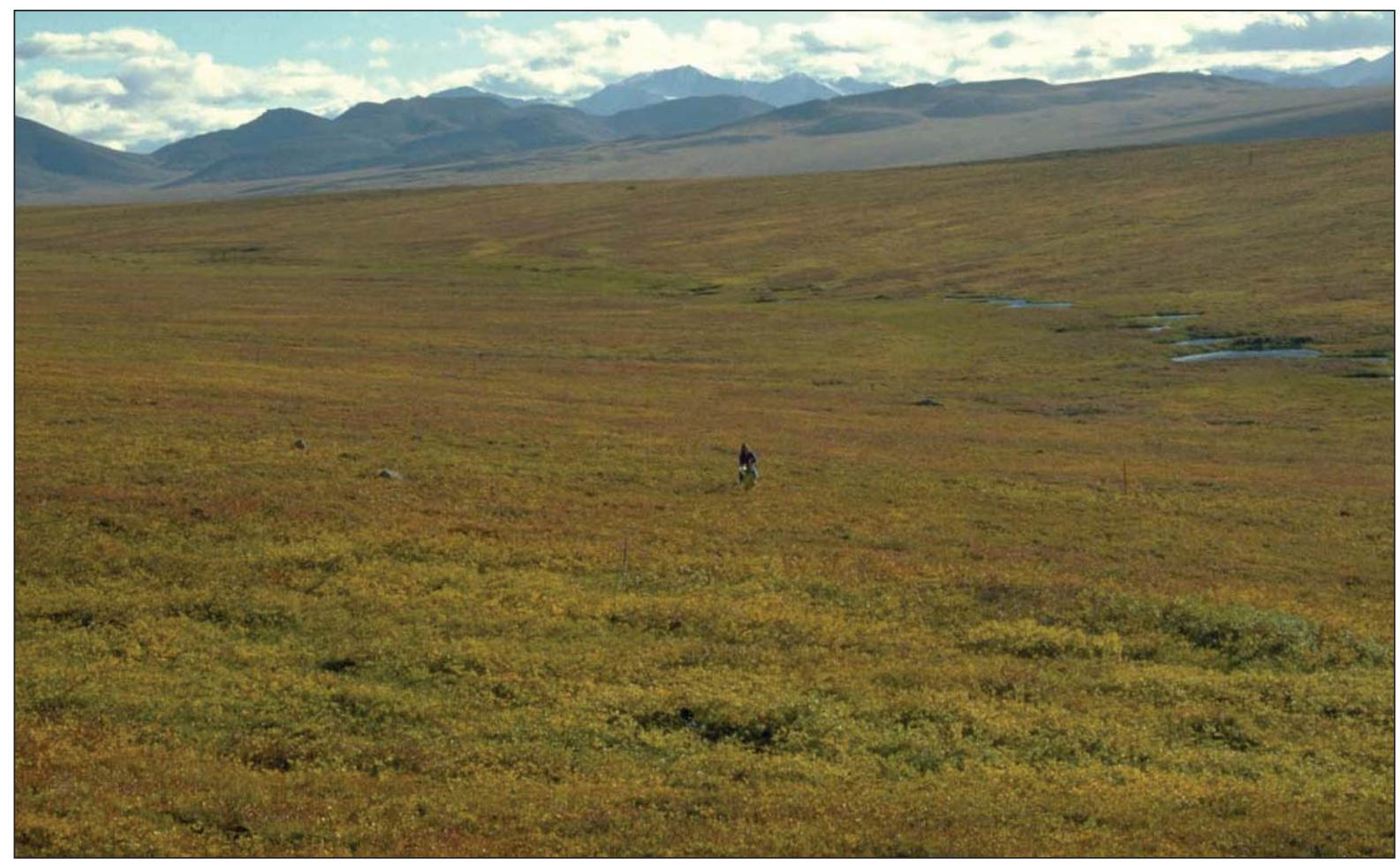

Figure 25. Sagavanirktok-age surface at Imnavait Creek. Photo by D.A. Walker.

years ago $\left(25-11.5 \mathrm{ka}^{14} \mathrm{C}\right)$, and formed extensive icestagnation features around Toolik Lake. Glacial flow patterns during the Itkillik II advance were generally similar to those of the present-day river drainages. Other deposits include river deposits, lacustrine deposits, fan deposits, and colluvial deposits. Local bedrock outcrops consist of sandstones, conglomerates, shales, and siltstones of the Chandler, Torok, and Fortress Mountain Formations.

\section{Stop 22: Entrance to Material Site 117, Weather station for permafrost observatory network}

As part of the Permafrost Observatory Network, several small climate stations have been established in Alaska and northwestern Canada (Osterkamp, 2003; Osterkamp and Romanovsky, 1999; Romanovsky and Osterkamp, 2001; Romanovsky and others, 2003). At each station the air and ground temperatures are recorded automatically. Active-layer depths are recorded manually. Figure 26 shows a summary of data from Franklin Bluffs, where a long record is available. Figure 27 is a long-term record of permafrost temperatures at $20 \mathrm{~m}$ depth at five stations along the permafrost transect from Happy Valley in the south to West Dock in the north.

\section{Stop 23: Material Site 117, Imnavait Creek research site}

Imnavait Creek (fig. 29) is a short 16-km- (10-mi-) long tributary of the Kuparuk River, named after Imnavait Mountain $(1,120 \mathrm{~m}[3,675 \mathrm{ft}])$, about $18 \mathrm{~km}$ (11 mi) north of the study site. Imnavait is an Inupiat term for sheep, referring to a herd of Dall sheep that visit this mountain. The Imnavait Creek watershed is defined

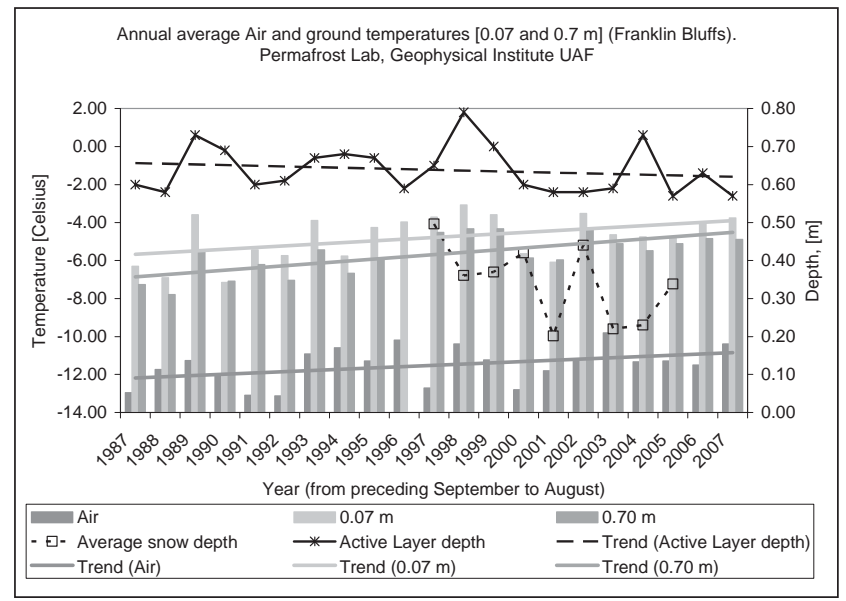

Figure 26. An example of long-term observed trends in active-layer depth, air temperature, soil temperature (0.07 and $0.7 \mathrm{~m}$ ), and snow depth near Franklin Bluffs, from 1987 to 2007. Courtesy of V.E. Romanovsky. 


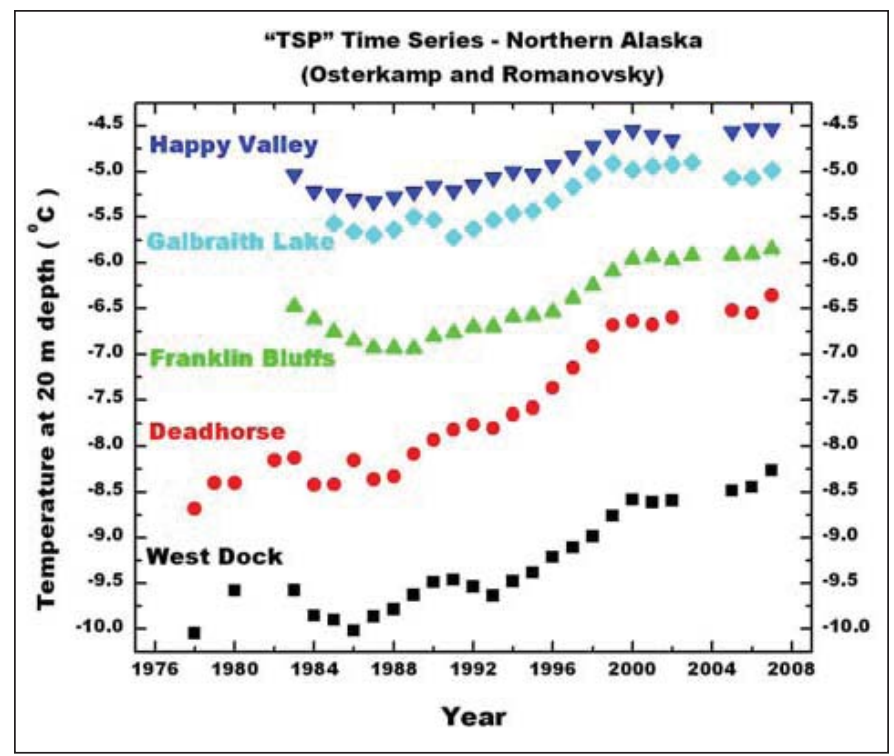

Figure 27. Long-term permafrost temperatures for sites on Alaska's North Slope. Courtesy of V.E. Romanovsky. as the $2.2 \mathrm{~km}^{2}\left(0.8 \mathrm{mi}^{2}\right)$ area above the road culvert at Material Site 117 (figs. 29, 30). The base elevation of the watershed is about $875 \mathrm{~m}$ $(2,870 \mathrm{ft})$ and the maximum elevation of the watershed is $945 \mathrm{~m}(3,100 \mathrm{ft})$. The watershed was the primary research site for the Department of Energy R4D (Response, Resistance, Resilience and Recovery of Arctic Systems to Disturbance) project. The R4D research was conducted primarily during the years 1985-1995 (Reynolds and Tenhunen, 1996). Most of the R4D research occurred within a 69 ha $(170 \mathrm{ac})$ portion of this watershed, along the west-facing hill slope and valley bottom. A primary focus of much of the research was the hydrological nutrient-transport processes in relationship to disturbances. The watershed has since become a research area for the Arctic LTER and other projects.

The site was selected for five primary reasons. (1) The terrain and vegetation are representative of broad expanses of the Arctic foothills. The slopes are dominated by tussock tundra vegetation, the zonal vegetation of the region, which covers a large percentage of the Alaskan Arctic region. The watershed contains

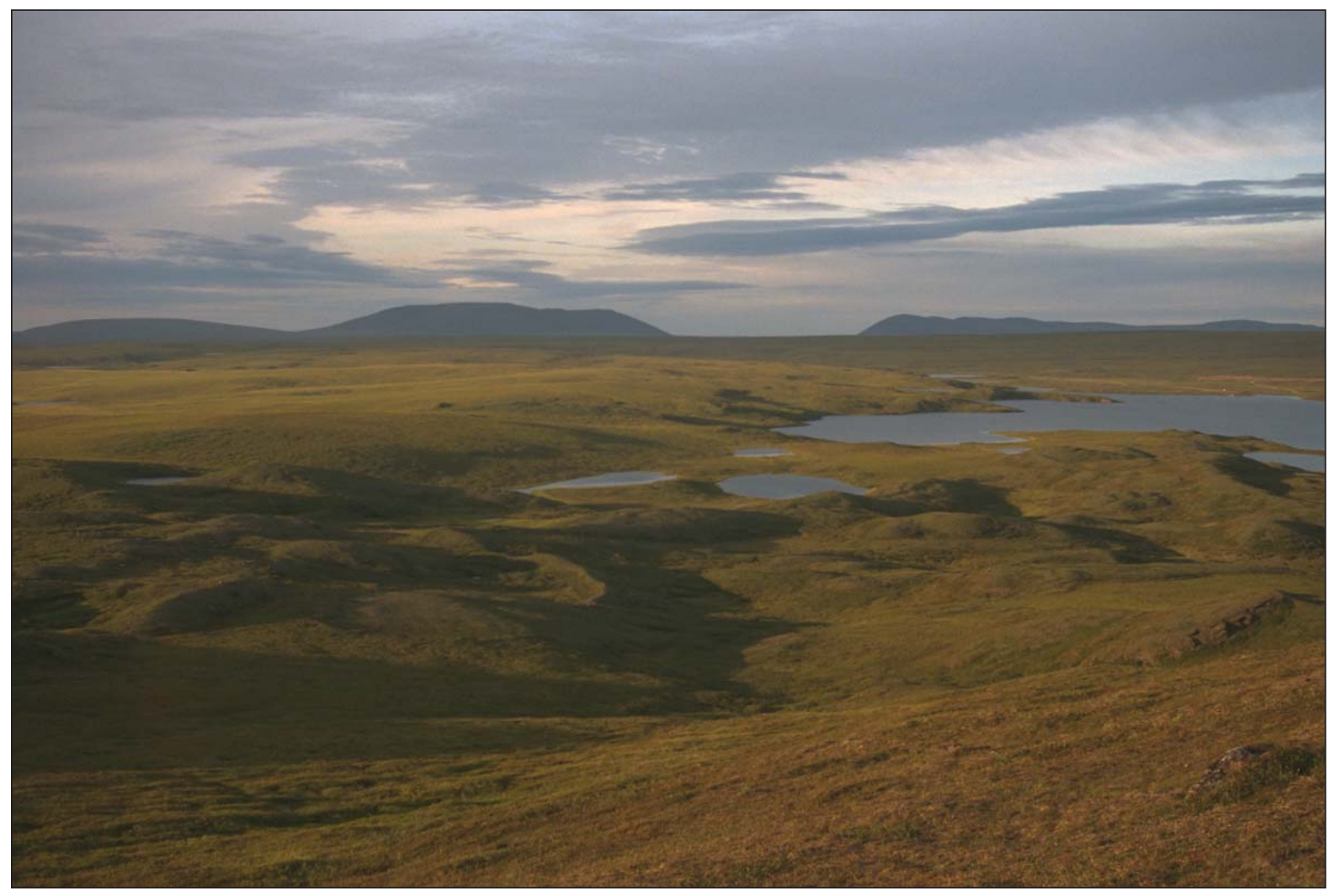

Figure 28. Itkillik II glacial surface viewed from Jade Mountain. Toolik Lake is in the background to the right of center. Photo by D.A. Walker. 


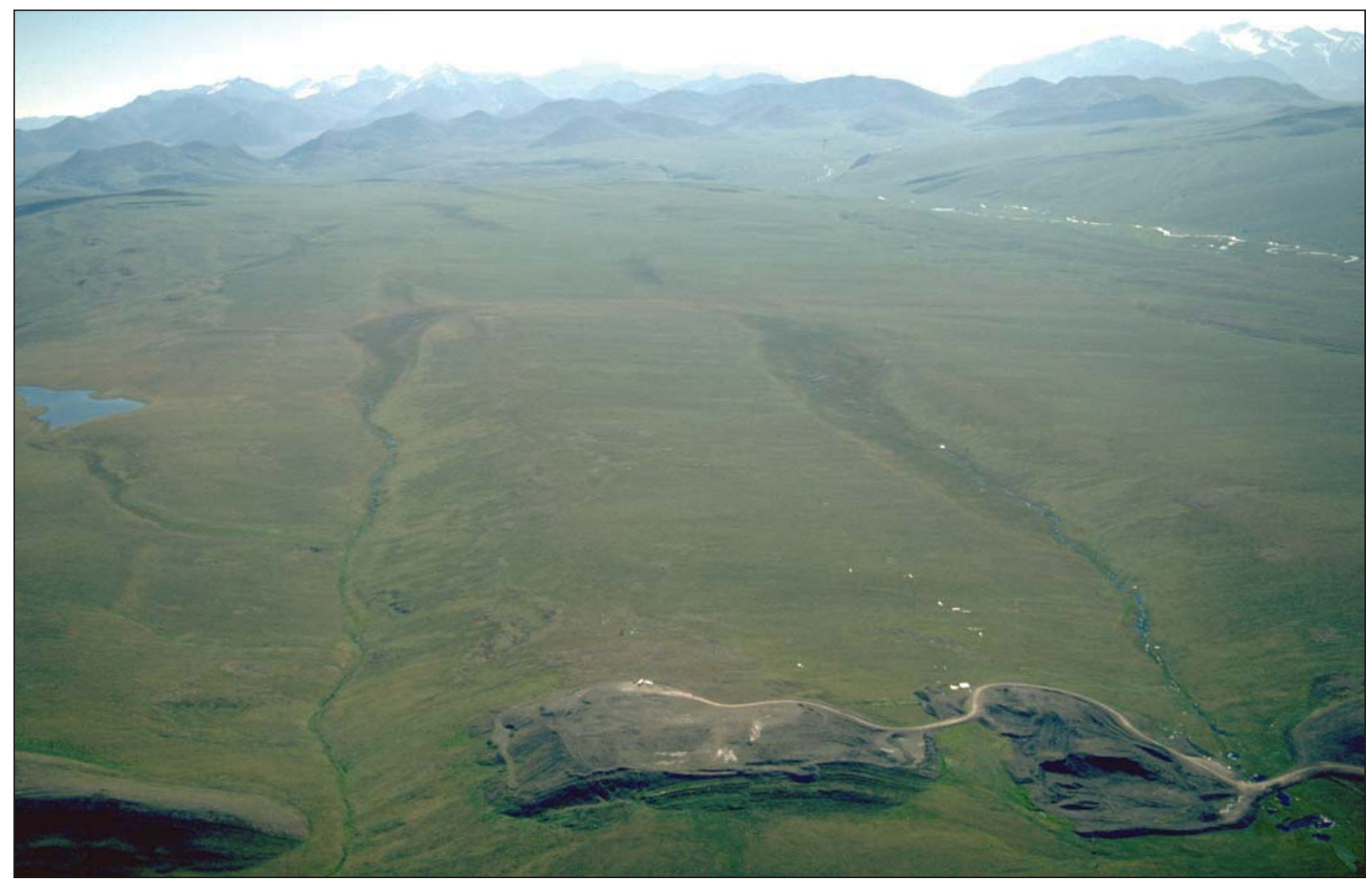

Figure 29. Imnavait Creek watershed (right) and Toolik River headwaters; Material Site 117 is in the foreground. The Kuparuk River is in the upper right. Photo by D.A. Walker.

a small colluvial basin typical of many headwater areas in the foothills. (2) The area has two small watersheds of similar size, Imnavait Creek and the headwaters of the Toolik River, which is about $1 \mathrm{~km}(0.6 \mathrm{mi})$ east of Imnavait Creek (fig. 29). The Toolik River could serve as a parallel site for whole-watershed experimental manipulations. (3) The site has ideal slopes for toposequence studies of vegetation, soils, and hydrology. (4) The site is about $3 \mathrm{~km}$ ( $2 \mathrm{mi}$ ) from the Dalton Highway and thus isolated from road dust and other disturbances associated with the trans-Alaska pipeline. (5) The site is about 10 $\mathrm{km}(6 \mathrm{mi})$ from the University of Alaska field station at Toolik Lake and thus easily accessible at all times of year for observations and experimental research.

\section{Hydrology of Imnavait Creek and neighboring watersheds, North Slope of Alaska}

Robert Gieck will lead a tour of the Imnavait Creek climate and hydrological research program at Imnavait Creek that has been ongoing since 1985. After the tour, we will have lunch at the top of the hill with a view to the north.

Imnavait Creek, as well as the other studied watersheds in the Toolik Field Station area, is underlain by continuous permafrost (250 m [275 yds] deep). It is treeless and dominated by long winters ( $\sim 9$ months). Soil profiles are composed of a surface organic layer of varying thickness, generally around 20 to $25 \mathrm{~cm}(8-10$ in) and underlain by mineral soils of glacial origin. Active-layer thicknesses generally average from 40 to 60 cm (16-24 in).

In 1993, the Imnavait Creek watershed study was expanded to include the upper Kuparuk $\left(142 \mathrm{~km}^{2} / 55\right.$ $\left.\mathrm{mi}^{2}\right)$ and greater Kuparuk $\left(8,140 \mathrm{~km}^{2} / 3,143 \mathrm{mi}^{2}\right)$ basins (fig. 30). The rationale for expanding the areal coverage of the hydrologic study was to include greater variation in topography (mountains and coastal plain) and look at the hydrologic response for a range of hydraulic gradients. In 1999, the Putuligayuk watershed $\left(471 \mathrm{~km}^{2} / 182\right.$ $\mathrm{mi}^{2}$ ) was added. It is unique in that the entire basin is located on the low gradient coastal plain. Hypsometric curves for these watersheds are shown in figure 31, with the elevation distribution of meteorological stations in each basin. Surface-water pooling in wetlands, ponds, and lakes is a major storage reservoir in this basin. Figure 30 shows the relative position of these watersheds and the location of meteorological stations. Each catchment is gauged continuously; the greater Kuparuk and Putuligayuk basins were initially gauged by the U.S. Geological Survey in 1971. While the greater Kuparuk has been continually gauged, the Putuligayuk was intermittent in the 1980s and then essentially downgraded to a crest gauge site. Unfortunately there is essentially no complementary hydrologic and meteorological data to 


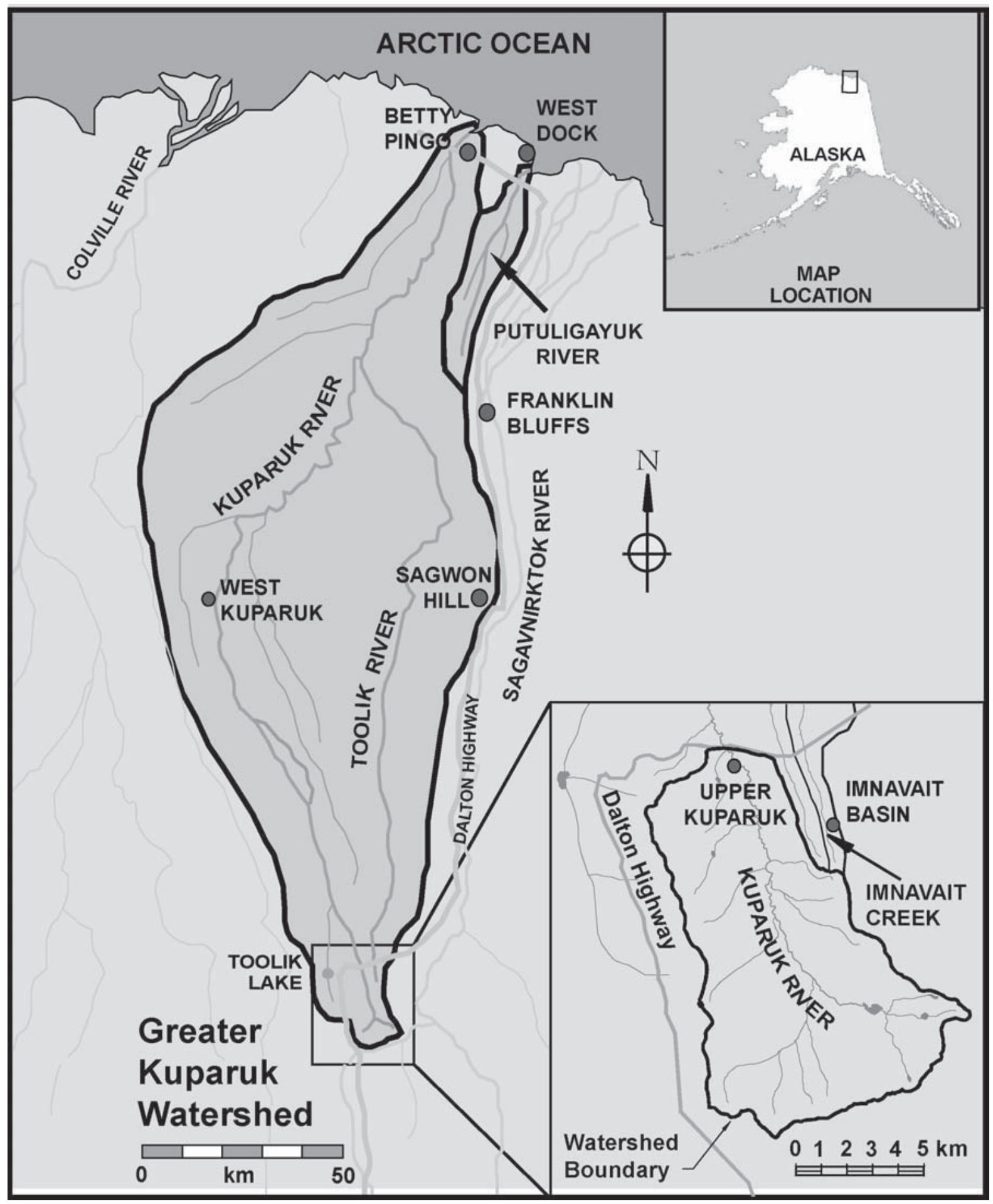

Figure 30. Location map of four nested watersheds being studied on the North Slope of Alaska; black dots indicate locations of meteorological stations (Kane and others, 2000). 


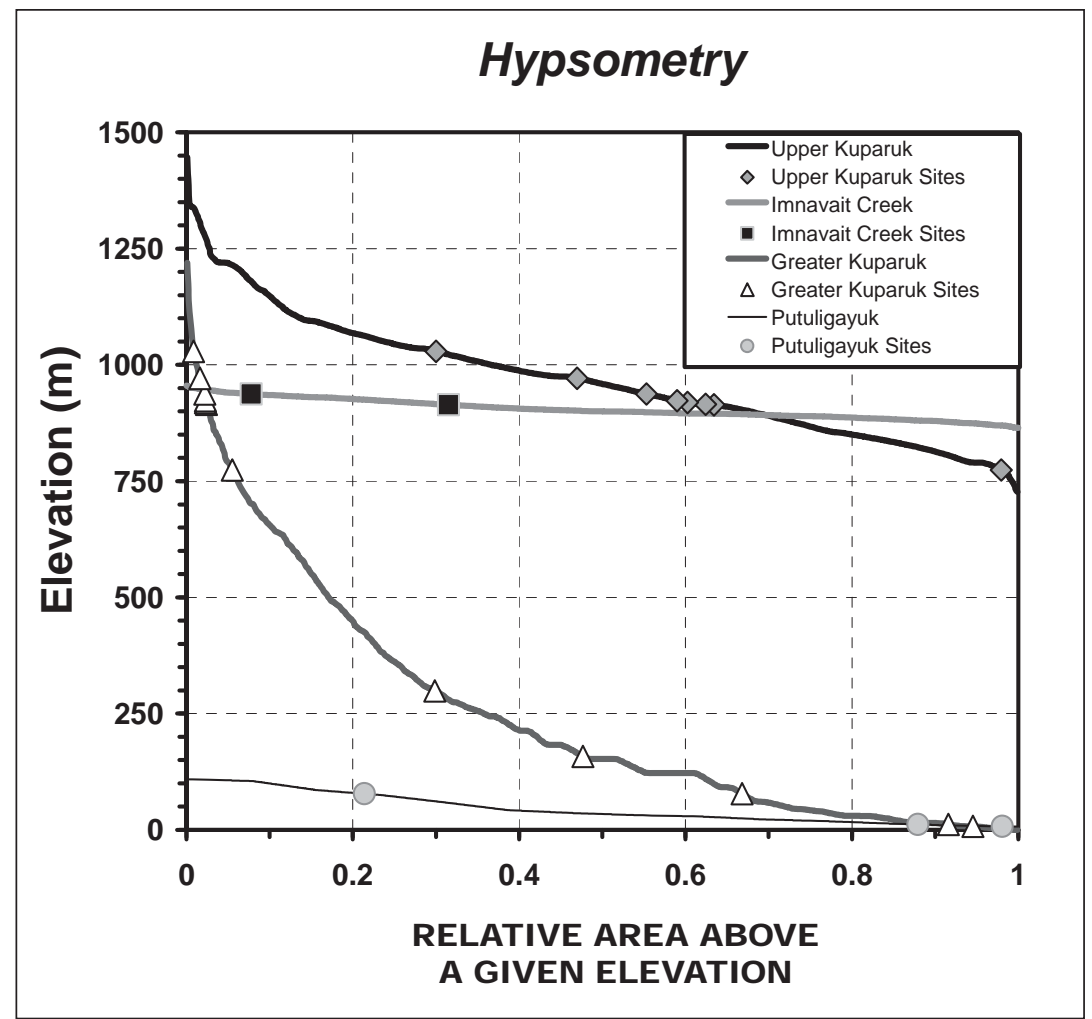

Figure 31. Hypsometric curves of four nested watersheds on the North Slope of Alaska with elevations of meteorological sites indicated (Kane and others, 2000). couple with the runoff data until we initiated our studies. Major floods have occurred in the headwater basins in 1999 and 2002; and droughts in 1990, 2005, and 2007.

Imnavait Creek is snow covered for 8 to 9 months of the year with ablation occurring in a 6-week window from late April until early June (fig. 32). Freeze-up is generally in mid-September ( \pm 2 weeks). Since it is a small catchment, it is prone to cease flowing in the summer months during periods of drought. Also during the winter months the flow ceases. Snowmelt is generally the major hydrologic event of the year, as it occurs in a 7- to 10-day period when not interrupted by a cold spell. The floods of record, however, are generated when the rainfall rate in the foothills exceeds the rate of ablation. The maximum summer flow exceeds the maximum snowmelt flood by a factor of 3. Flood frequency analyses of Imnavait Creek show that one rainfall flood was the flood of record (fig. 33).

Subsurface flow in Imnavait Creek is confined to the active layer. In the greater Kuparuk basin there are some springs; however, chemical analyses of this water show that it is of recent origin and that the water is stored in near-surface aquifers along the stream channel rather than sub-permafrost aquifers. To the east of the Kuparuk basin there are springs that flow throughout the year. In this case, the origin of the water is clearly subpermafrost groundwater where the permafrost thickness probably exceeds $300 \mathrm{~m}$ (about $330 \mathrm{yds}$ ).
Each of the four basins is hydrologically unique; the upper Kuparuk River and Imnavait Creek catchments are the most similar. Both have floods of record that are generated during the summer months (see fig. 34 for the upper Kuparuk River). For the entire Kuparuk River and Putuligayuk River catchments the floods of record are snowmelt generated (see fig. 35 for the entire Kuparuk River). The largest summer flood of record for the entire Kuparuk basin followed a large headwater storm in August 2002. The Putuligayuk River basin does not experience summer floods of any significance. For the low-gradient coastal plain, summer evapotranspiration (ET) can exceed summer precipitation. When this occurs, the extensive wetlands, ponds, and lakes experience surface storage deficits and fragmentation of the drainage network connecting these surface water bodies.

In the headwater catchments, snowfall precipitation is about one-third of the total annual precipitation. About two-thirds of the snowpack leaves the basin as runoff, while for the summer season 40 percent of precipitation leaves as runoff. On an annual basis, about half of the precipitation leaves as evapotranspiration, while the remaining half leaves as runoff. On the coastal plain with the extensive lakes, ponds, and wetlands, coupled with a low-gradient system, it would be anticipated that the runoff response would be abated. It is interesting to see that on average ( 9 years), 78 percent of the coastal plain snowpack leaves as runoff, while only 40 percent 


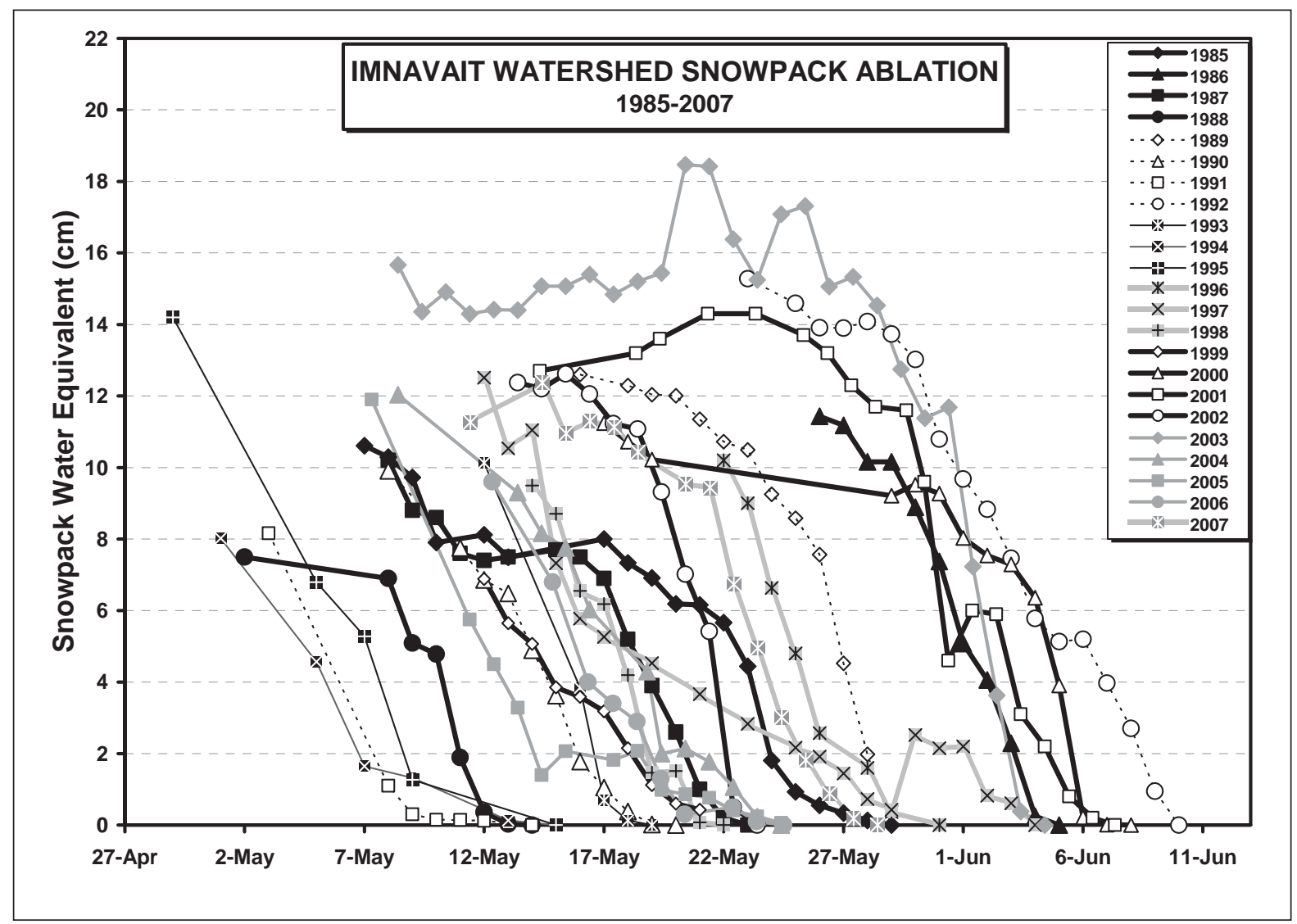

Figure 32. Twenty-three-year time window of snow ablation at Imnavait Creek, North Slope, Alaska (Kane and others, 2008).

Figure 33. Flow frequency curves for Imnavait Creek showing snowmelt and rainfall floods and low flow (Kane and others, 2008).

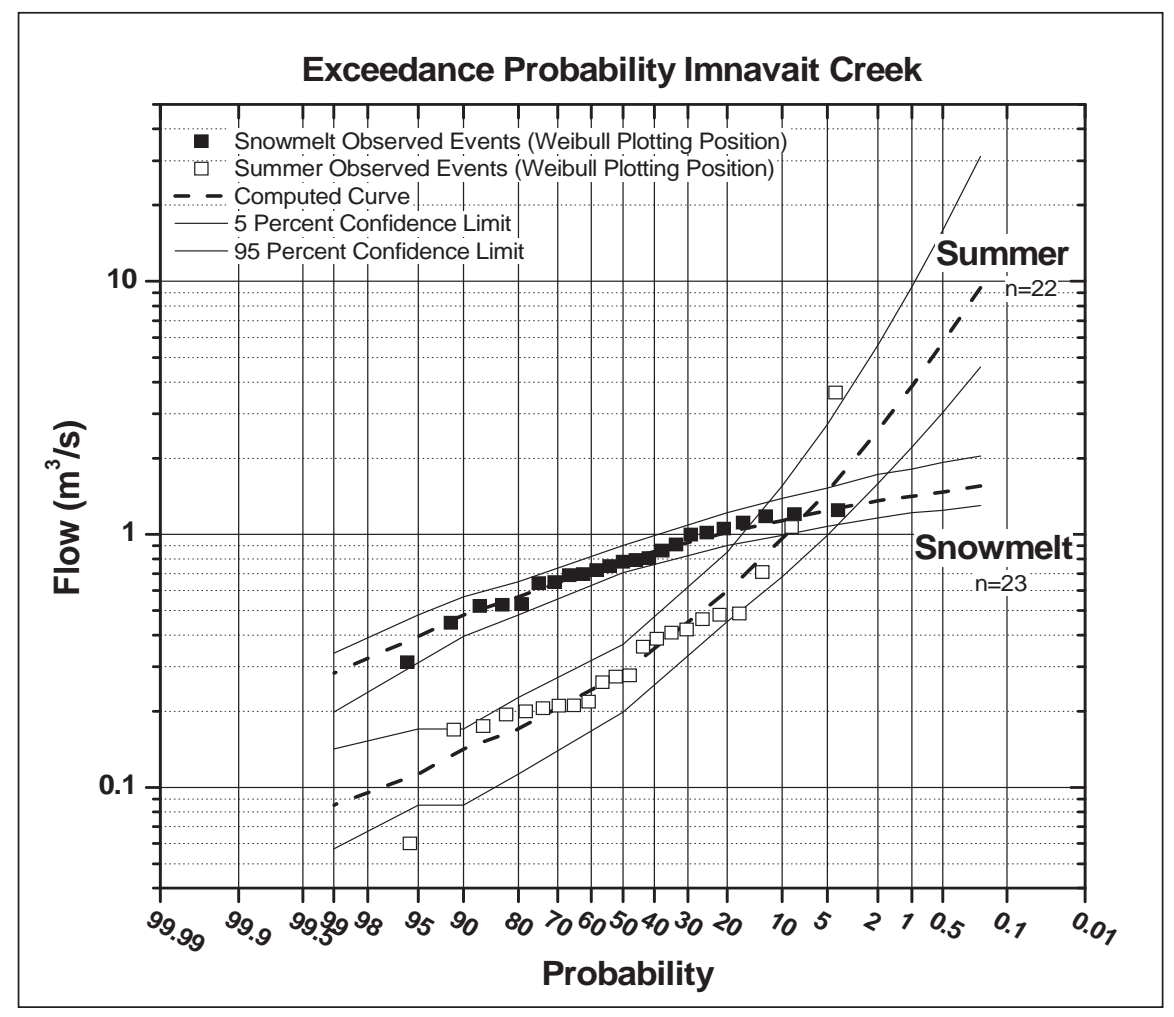




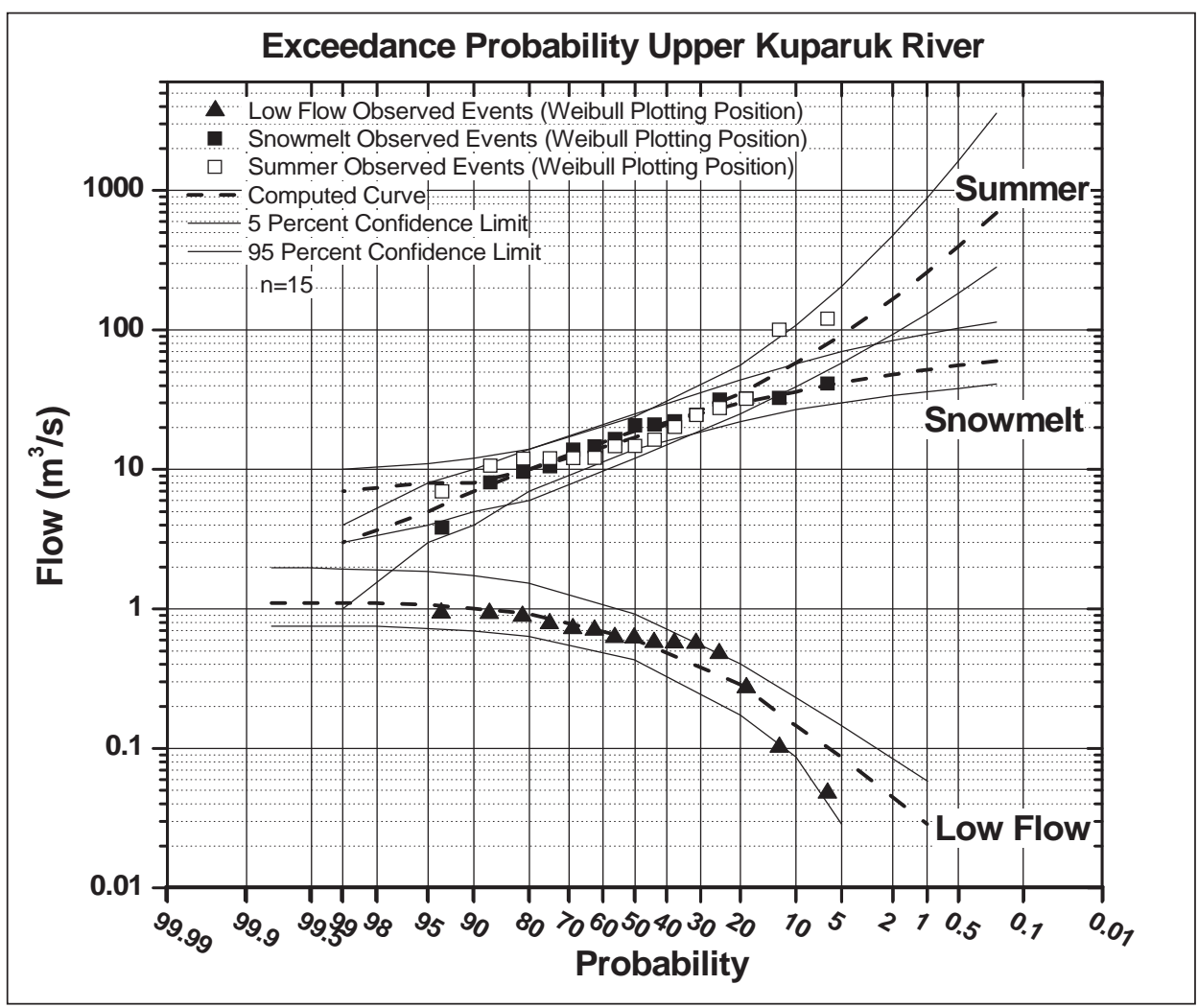

Figure 34. Flow frequency curves for the upper Kuparuk River basin showing snowmelt and rainfall floods and low flow (Kane and others, 2008).

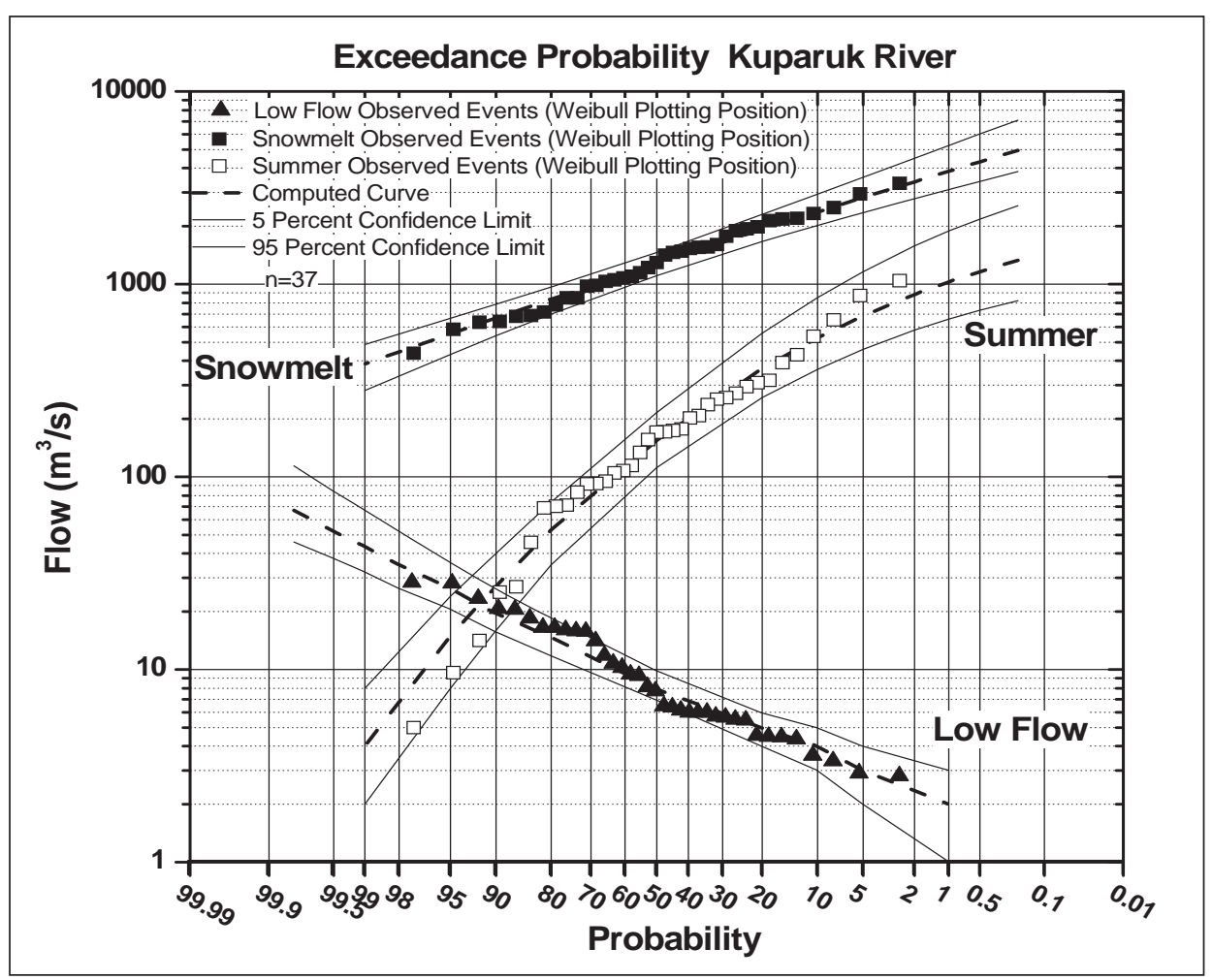

Figure 35. Flow frequency curves for the entire Kuparuk River basin, showing snowmelt and rainfall floods and low flow (Kane and others, 2008). 
of the summer precipitation leaves as runoff. The summer runoff response of the steeper headwater streams is identical to the low-gradient coastal areas. During the summer months, evapotranspiration is the major flux of water leaving these basins. Storage in the ponds, lakes, and wetlands is an important component of the hydrologic cycle of these low-gradient watersheds.

\section{Stop 24: North end of Toolik Lake Itkillik II surfaces}

After driving to the north end of Toolik Lake at the end of the camp's old airstrip, we will take an afternoon walking tour of an Itkillik II surface, boulder fields, and a curious "kame-like" knob. During the walk we will also stop at an old, abandoned homemade vehicle, walk down to the lakeshore, and view some experimental research sites.

As mapped by Hamilton (2003), Toolik Lake is confined to the north and west by glacial deposits of Itkillik II age (fig. 36). These deposits were derived from the neighboring Itkillik River valley, the type locality for the Itkillik glaciation. Ice overflowed that valley's eastern flank, spreading eastward into the area northwest and north of Toolik Lake. As the glacier began to downwaste, it became cut off from still-active ice in the Itkillik River valley, causing it to stagnate across a broad lowland. As it stagnated, the glacier was washed by abundant melt- water, creating generally well-drained gravel deposits that provide excellent hiking terrain.

Our walking tour will begin on an abandoned meltwater channel that extends north from the northeast corner of Toolik Lake. This gravel-floored feature is the distal part of an outwash apron and valley train that originates at an end moraine about $3.5 \mathrm{~km}$ (2.2 mi) south of Toolik Lake. Because the outwash skirted Toolik Lake to the east, it must have been diverted in that direction by a large stagnant mass of glacier ice that filled the lake basin at that time.

As we hike across the stagnant-ice terrain, overlooks provided by some of the higher gravel knobs and ridges will enable us to view a wide variety of glacial features such as end moraines and lateral moraines, kames and kame terraces, outwash trains and meltwater channels, and water-filled kettle depressions. The flanks of several kettles are actively collapsing at the present time, indicating that residual glacier ice may still be present locally.

\section{LTER research sites on the north end of Toolik Lake}

The Arctic Long-Term Ecological Research (LTER) project maintains long-term experimental manipulations in lake, stream, and terrestrial ecosystems near Toolik Lake. The research site at the north end of Toolik Lake is one of the main sites for the LTER terrestrial research

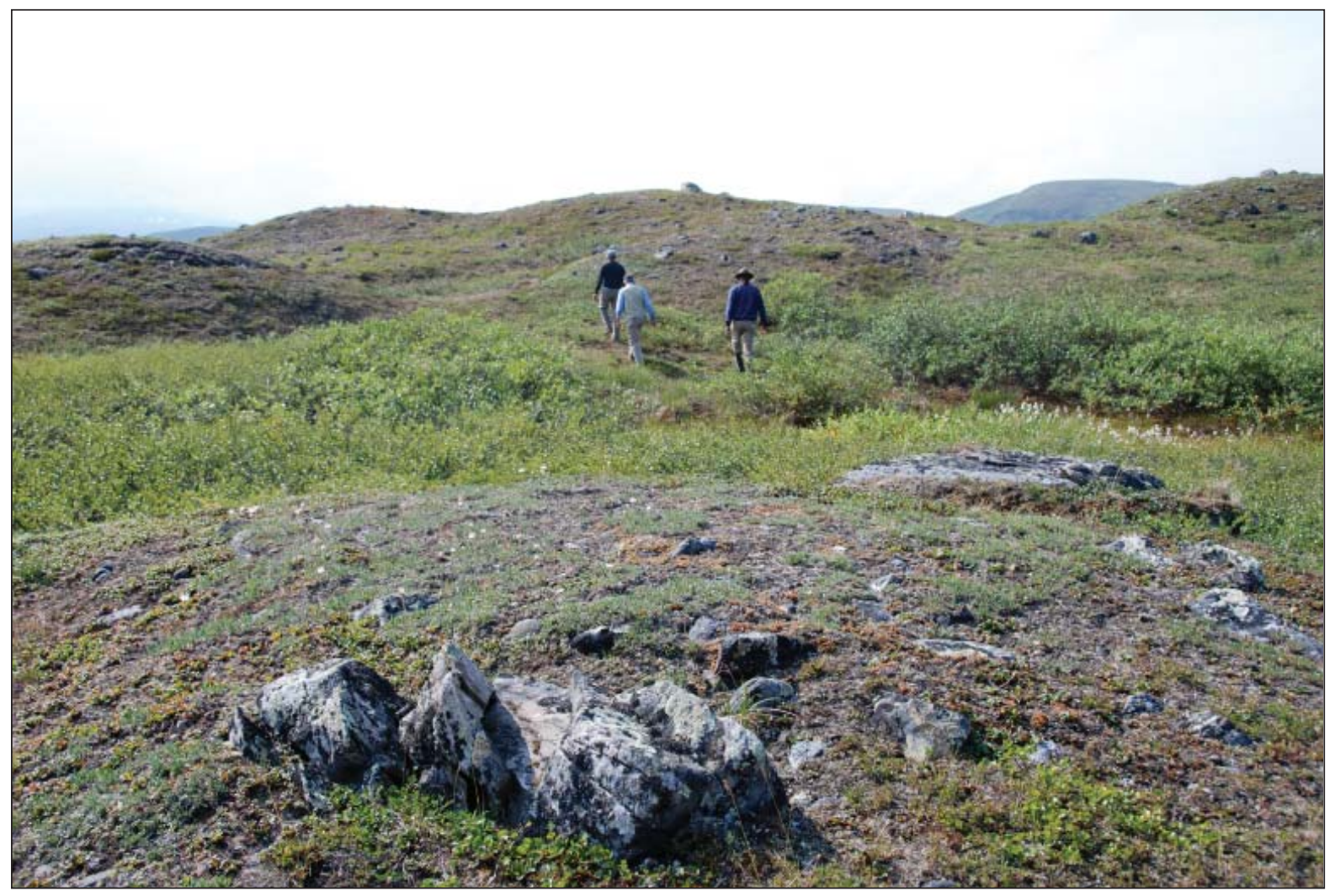

Figure 36. Boulder-littered surface of Itkillik II age at Toolik Lake. Photo by D.A. Walker. 
group's activities. Other sites are on the south and west sides of the lake, at Imnavait Creek, and a site along the Sagavanirktok River near the Department of Transportation camp at Slope Mountain. The terrestrial group currently maintains 12 major experiments as part of the LTER research, the earliest of which began in 1980 (table 3). Each summer a major biomass harvest of one or more of these experiments is completed. The general aim is to harvest each experiment at least once every 3-6 years, but the schedule is kept flexible to allow coordination of harvests with collaborating, independently-funded projects. Because these ecosystems continue to respond to treatments, new insights are gained about ecosystem regulation with each harvest.

In the last 3-5 years, emphasis has shifted to two of the newer long-term experiments, one focused on long-term effects of herbivory and the second on effects of individual species and plant functional types on element cycling. Both of these experiments include analysis of factorial interactions with fertilizer addition, the most important treatment variable in earlier experiments (table 3).

The experimental plots at Stop 25 include: (1) an $\mathrm{N} \times \mathrm{P}$ factorial fertilizer experiment and a shading experiment, both set up in 1988, (2) an herbivore exclosure experiment set up in 1996, and (3) a rainfall exclusion experiment set up in 2007 (fig. 37). In the ecosystem classification used by the Arctic LTER, this site is classified as a "Dry Heath."

At this Dry Heath site, the exclosure experiment is the one most recently sampled in detail. The central hypothesis of this experiment is that herbivores play an important role in controlling tundra plant species composition, but are less important as direct controls on productivity or nutrient turnover at 1-10-year scales. It is hypothesized that herbivores induce changes in species composition more rapidly under fertilization, but that fertilized plots with or without herbivores will converge to similar species composition after about 10 years. The herbivory manipulation consists of a nested exclosure treatment with an outer, large-mesh fence excluding caribou and an inner, small-mesh fence excluding lemmings, voles, and ground squirrels. The experiment was set up in July 1996, with harvests in 1999, 2003, and 2006, in two contrasting ecosystem types, including the Dry Heath at Stop 25 and the main LTER experimental site in Moist Acidic Tundra (MAT) above the south shore of Toolik Lake (visible from Stop 25).

After 10 years of treatment, the Dry Heath tundra herbivore exclosure resulted in greater above-ground biomass both with and without fertilizer addition. The fertilizer greatly reduced above-ground lichen, moss, and evergreen biomass but the reductions were smaller in fertilized exclosures. The increase in graminoids in fertilized plots at both sites was reduced in the exclosures; this may be the result of herbivory favoring graminoids in fertilized plots or a lack of herbivory favoring deciduous shrubs, or both.

In contrast to the dry plots, the Moist Acidic Tundra treatments showed little, if any, impact of herbivore exclosure on above- or below-ground plant biomass. The fertilizer-only treatment in MAT did reproduce previous results (Chapin and others, 1995, Shaver and others, 2001, Mack and others, 2004), with a shift in species composition toward dominance by deciduous shrubs and major reductions or complete loss of lichens, mosses, and evergreen shrubs.

Figure 37. Rainfall exclusion experimental plot on the north side of Toolik Lake. Photo courtesy of Gus Shaver.

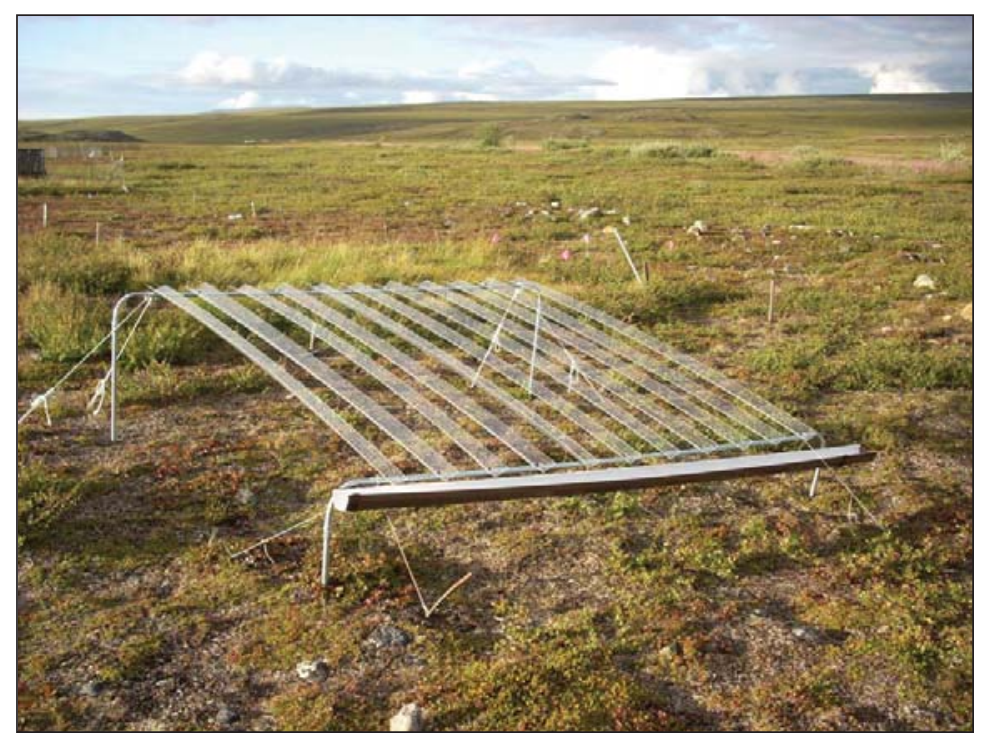


Table 3. List of terrestrial research experiments for the Arctic Long Term Ecological Research (LTER) Project

\begin{tabular}{|c|c|c|c|c|}
\hline Location & $\begin{array}{l}\text { Year } \\
\text { Started }\end{array}$ & Ecosystem Type & Treatments & Major Harvests \\
\hline $\begin{array}{l}\text { Toolik Lake } \\
\text { (Historic Site) }\end{array}$ & 1980 & Acidic Tussock & Control, N+P Fert & $\begin{array}{l}1982,1983,1984 \\
1989,1995,2000\end{array}$ \\
\hline \multirow[t]{10}{*}{$\begin{array}{l}\text { Toolik Lake } \\
\text { (main LTER } \\
\text { site) }\end{array}$} & 1988 & $\begin{array}{l}\text { Acidic Tussock } \\
\text { Wet Sedge } \\
\text { Dry Heath } \\
\text { Riparian Shrub }\end{array}$ & $\begin{array}{l}\text { Control } \\
\mathrm{N}, \mathrm{P}, \mathrm{N}+\mathrm{P} \\
\text { Greenhouse } \\
\text { Shade } \\
\text { Greenhouse }+\mathrm{N}+\mathrm{P} \\
\text { Shade+N+P }\end{array}$ & $\begin{array}{l}\text { Tussock 2001, } 2002 \\
\text { Sedge 1994, } 2001 \\
\text { Heath } 1996\end{array}$ \\
\hline & 1994 & $\begin{array}{l}\text { Acidic Tussock } \\
\text { Dry Heath }\end{array}$ & Snow fence & $\begin{array}{l}\text { Annual point-frame } \\
\text { monitoring, 1994- } \\
2003\end{array}$ \\
\hline & 1996 & $\begin{array}{l}\text { Acidic Tussock } \\
\text { Dry Heath }\end{array}$ & $\begin{array}{l}\text { Control } \\
\mathrm{N}+\mathrm{P} \\
\text { Herbivore Exclosure } \\
\text { Exclosure }+\mathrm{N}+\mathrm{P}\end{array}$ & Tussock 1999-2002 \\
\hline & 1997 & $\begin{array}{l}\text { Nonacidic Tussock } \\
\text { Nonacidic Nontussock }\end{array}$ & $\begin{array}{l}\text { Control } \\
\mathrm{N}, \mathrm{P}, \mathrm{N}+\mathrm{P} \\
\text { Greenhouse } \\
\text { Greenhouse }+\mathrm{N}+\mathrm{P}\end{array}$ & Tussock 1999-2001 \\
\hline & 1997 & $\begin{array}{l}\text { Acidic Tussock } \\
\mathrm{N}+\mathrm{P} \\
\text { Removal+N+P }\end{array}$ & Species removal & 1999,2003 \\
\hline & 1998 & $\begin{array}{l}\text { Acidic Tussock } \\
\text { Nonacidic Tussock } \\
\text { Nonacidic Nontussock }\end{array}$ & $\begin{array}{l}\text { Sulfur } \\
\text { Lime }\end{array}$ & \\
\hline & 2001,2002 & $\begin{array}{l}\text { Wet Sedge (2001) } \\
\text { Acidic Tussock (2002) }\end{array}$ & $\begin{array}{l}{ }^{14} \mathrm{C} \text { addition, control } \\
\text { and } \mathrm{N}+\mathrm{P} \text { fert }\end{array}$ & $\begin{array}{l}2001,2002,2003 \\
2004,2005\end{array}$ \\
\hline & 2006 & Acidic Tussock & Low-level N+P & \\
\hline & 2006 & $\begin{array}{l}\text { Acidic Tussock } \\
\text { Riparian Shrub }\end{array}$ & Snow fence & \\
\hline & 2007 & Dry Heath & Rainfall exclusion & \\
\hline $\begin{array}{l}\text { Sag River } \\
\text { Toposequence }\end{array}$ & 1984 & $\begin{array}{l}\text { Moist Tussock } \\
\text { Dry Heath } \\
\text { Snowbed } \\
\text { Equisetum/Forb } \\
\text { Wet Sedge } \\
\text { Riparian Shrub }\end{array}$ & $\begin{array}{l}\text { Control } \\
\mathrm{N} \\
\mathrm{P} \\
\mathrm{N}+\mathrm{P} \\
\mathrm{C} \text { enrichment (starch, } \\
\text { sawdust) } \\
\text { Lime }\end{array}$ & $\begin{array}{l}\text { All sites 1988; } \\
\text { Wet Sedge 1994, } \\
2001\end{array}$ \\
\hline
\end{tabular}

$\mathrm{N}=$ Nitrogen; $\mathrm{P}=$ Phosphorus $; \mathrm{C}=$ Carbon; Fert = Fertilization 
Table 4. Selected characteristics of moraine sequences of Itkillik age in northern and southern valleys of the central Brooks Range (Hamilton, 1986).

\begin{tabular}{|c|c|c|c|c|c|c|}
\hline & \multicolumn{2}{|c|}{ Itkillik I } & \multicolumn{2}{|c|}{ Itkillik II Maximum } & \multicolumn{2}{|c|}{ Late Itkillik II } \\
\hline & $\begin{array}{l}\text { Northern } \\
\text { valleys }\end{array}$ & $\begin{array}{c}\text { Southern } \\
\text { valleys }\end{array}$ & $\begin{array}{l}\text { Northern } \\
\text { valleys }\end{array}$ & $\begin{array}{c}\text { Southern } \\
\text { valleys }\end{array}$ & $\begin{array}{l}\text { Northern } \\
\text { valleys }\end{array}$ & $\begin{array}{c}\text { Southern } \\
\text { valleys }\end{array}$ \\
\hline Crest width (m) & $5-20$ & $5-15$ & $3-5$ & $2-3$ & $5-8$ & $2-5$ \\
\hline Maximum slope angle $\left(^{\circ}\right)$ & $15-20$ & $14-20$ & $18-23$ & $16-22$ & $13-21$ & $16-17$ \\
\hline Irregularities per $200 \mathrm{~m}$ & $1-6$ & $0-3$ & $3-6$ & $2-4$ & 4 & $2-4$ \\
\hline Boulders per $250 \mathrm{~m}^{2}$ & $9-213$ & $0-135$ & $12-215$ & $0-191$ & $4-144$ & $60-80$ \\
\hline Boulder protrusion $(\mathrm{cm})$ & $20-50$ & Up to 20 & $40-80$ & $20-30$ & $10-20$ & Up to $1 \mathrm{~m}$ \\
\hline Soil color, maximum & 7.5 YR 5/6 & 7.5 YR 5/8 & $10 Y R$ 4/4 & 10 YR 5/6 & 10 YR $5 / 3$ & $10 \mathrm{YR} 5 / 6$ \\
\hline
\end{tabular}

Ecosystem effects of different-aged glacial surfaces

Vegetation patterns are strongly associated with the glacial history of the region. Older surfaces have less dry nonacidic tundra, fewer snowbeds, more acidic tundra, more shrub tundra, much less moist nonacidic tundra, fewer riparian areas, fewer rich fens, more poor fens, and fewer lakes.

Two modern plant communities are most common in the Arctic foothills region: Moist Acidic Tundra (MAT, also known as tussock tundra or the formal plant association name Sphagno-Eriophoretum vaginati), and its counterpart, Moist Nonacidic Tundra (MNT) (Dryado integrifoliae-Caricetum bigelowii), which occurs on moist surfaces with $\mathrm{pH}$ above about 5.5. Similar plant associations are also abundant in parts of eastern Siberia (Razzhivin, 1999) and northwestern Canada. MNT occurs most abundantly on younger surfaces including Itkillik-age glacial surfaces, loess deposits, solifluction features, frost-boil complexes, and alluvial terraces (for example, Walker and Everett, 1987; Walker and others, 2008, in press), whereas MAT forms under conditions of long-term site stability. MAT is the primary vegetation on rolling upland surfaces throughout the Arctic foothills. MNT is floristically much more diverse than tussock tundra, and is important with respect to regional biodiversity. Several authors have noted the effect of soil $\mathrm{pH}$ on tundra plant diversity (Walker, 1985; Gough and others, 2000).

Peat formation and ice aggradation on older surfaces leads to restricted drainage, a general acidification of the soils, and the introduction of Sphagnum mosses to wet hill slopes (paludification) (Walker and Walker, 1996). The increase in mosses changes the soil chemistry, hydrology, and soil thermal properties, resulting in peat forming acidic mires in colluvial basins, extensive water track development, and tussock tundra on gentle hill slopes (Jorgenson, 1984; Walker and others, 1989). Paleoecological studies from lakes on the Itkillik II- and Sagavanirktok-age surfaces near Toolik Lake indicate that both surfaces likely had tundra with many prostrate dwarf shrub and species indicative of dry, non-paludified conditions (for example, Equisetum, Thalictrum, Rosaceae, Encalypta, Selaginella) during the early part of the Holocene (11,300 to 10,000 cal yr BP) (Oswald and others, 2003). Plants typically found in acidic tussock tundra (for example, Rubus chamaemorus, Sphagnum, Ericales, Betula, Polygonum bistorta) increased on the older surfaces between 10,000 and 7,500 years ago. The finer-grained soils on the older surfaces are thought to have promoted higher soil moisture, greater plant cover, thicker organic soil horizons, shallower active layers, aggradation of permafrost, and acidic soils.

\section{Stop 25: Milepost D-298, Itkillik I/II glacial bound- ary overlooking the Sagavanirktok River}

Many of the effects of surface age on landscapes can be seen from the top of this crest. The overlook views the Sagavanirktok River valley where the Itillik I and II glaciers flowed north out of the Brooks Range. Those glaciers filled the valley, but did not cover the older surfaces of Sagavanirktok age on the high ground that we have just crossed between here and the overlook above Toolik Lake (Stop 21).

On younger Itkillik II surfaces, kame and kettle topography and very little loess characterize the landscape. Moraines and kames of Itkillik II age typically are steep-sided, with irregular narrow crests (table 4). Their flanks as well as crests are stony, with solifluction present only locally. Soils are weakly developed, and surface boulders are little weathered. In the rivers, steep bouldery rapids generally occur where end moraines cross valley centers.

This boundary between surfaces of Itkillik I and Itkillik II age is the most striking glacial boundary within the entire Brooks Range glacial succession. Glacial deposits of Itkillik I age are significantly older, with an estimated age range of 55-105 ka. Moraines assigned to the Itkillik I advance have broader, smoother crests compared to those of Itkillik II age (table 4), and their flanking slopes have 
been modified by solifluction. Erratic boulders are common, but are scattered across tundra-covered surfaces. Soils are more deeply developed on well-drained moraine and kame crests, but otherwise are organic-rich and gleyed, with permafrost at shallow depth. End moraines of Itkillik I age are more broadly dissected in valley centers, and commonly have outwash terraces of Itkillik II age inset within their truncated ends. Stream gradients steepen slightly at moraine crossings, but the streams form shallow riffles rather than steep rapids.

\section{Dust effects along the Dalton Highway}

During the pipeline construction and the years afterward, road dust was a serious hazard along the highway and caused substantial changes to the vegetation near the road. The flat section of road between Stop 24 and Material Site 117 was a good place to study the effects of road dust on acidic tundra during the Cold Regions Research \& Engineering Laboratory (CRREL) baseline engineering and ecological baseline investigations along the Dalton Highway (Brown and Berg, 1980). Dust and its effects on vegetation were monitored during the 1970s and 1980s (Everett, 1979; Werbe, 1980; Walker and Everett, 1987). The studies on acidic tundra near Toolik were contrasted with studies of a nonacidic site near Sagwon (Auerbach and others, 1997). The overall effects on vegetation were more pronounced in acidic tundra:

“... Initial substrate $\mathrm{pH}$ appears to control the degree of response to disturbance by road and calcareous road dust. Soil at the acidic site is normally $p H 4.0$, whereas in the disturbed area next to the road soil $\mathrm{pH}$ was as high as $7.3 \pm 0.07$ (at $2 \mathrm{~m}$ from the road edge). Soils next to the road had lower nutrient levels, altered organic horizon depth, higher bulk density, and lower moisture. Effects on snowpack include both increased drifting in the lee of the road and earlier meltout near the road due to dustinduced change in albedo. Permafrost thaw was deeper next to the road at both sites, and potentially could affect road structure detrimentally. Vegetation biomass of most taxa was reduced near the road at both sites. Total aboveground biomass of nonacidic tundra ranged from $330.0 \pm$ $34.72 \mathrm{~g} / \mathrm{m}^{2}$ (mean $\pm 1 \mathrm{SE}$ ) at $2 \mathrm{~m}$ from the road to $690.7 \pm$ $94.52 \mathrm{~g} / \mathrm{m}^{2}$ at $100 \mathrm{~m}$ away from the road. Total biomass of acidic tundra ranged from $150.5 \pm 16.60 \mathrm{~g} / \mathrm{m}^{2}$ at $5 \mathrm{~m}$ from the road to $743.1 \pm 168.98 \mathrm{~g} / \mathrm{m}^{2}$ at $100 \mathrm{~m}$ from the road. Species richness in acidic tundra next to the road was less than half of that at $100 \mathrm{~m}$ away from the road. Community composition was altered most noticeably in acidic tundra. The moss Tomentypnum nitens, dominant in nonacidic arctic tussock tundra, was nearly equally abundant at all distances from the road at the nonacidic tundra site, whereas Sphagnum mosses, dominant in acidic low arctic tussock tundra, were virtually eliminated near the road at the acidic tundra site. Salix lanata was more abundant next to the road at the nonacidic site... [V] ariation in vegetation cover is explained by distance from the road." (Auerbach and others, 1997).

In recent years, dust abatement techniques including the addition of desiccants (calcium chloride), chip sealing the road surface, and paving large sections of the road have substantially reduced the dust impacts.

\section{Day 4}

Overview: Toolik Lake to Deadhorse $(208 \mathrm{~km}$ [130 mi]). On the fourth day of the field trip we will travel through the Arctic foothills and the Arctic coastal plain. Our stop at Slope Mountain will allow us to observe Dall sheep, examine an elevated section of the trans-Alaska pipeline, and explore massive ground ice at the base of a small hill. The route parallels the Sagavanirktok River, type locality of the Sagavanirktok glaciation, where we will investigate some of the ancient glacial moraines and river terraces that span the entire Pleistocene period. At Happy Valley we will visit one of the study sites of the Circumpolar Active Layer Monitoring (CALM) project, and review some of the results of the $\mathrm{CO}_{2}$ - and energy-flux monitoring that occurred here during the FLUX and ATLAS studies in the 1990s. At the Sagwon site we will visit a long-term climate monitoring site and a site along the North American Arctic Transect that is examining transitions in patterned-ground forms along the climate gradient. Our stop at Franklin Bluffs, on the coastal plain, will allow us to look at the braided Sagavanirktok River and discuss some of the research that is occurring nearby. Near Prudhoe Bay, we will have an opportunity to look at bank erosion along the Sagavanirktok River, and thermal erosion of ice wedges in a network of low-centered ice-wedge polygons.

The major theme of the day is Arctic transitions associated with (1) the lower summer air temperatures as we approach the coast; (2) the major physiographic boundary between the Arctic coastal plain and the foothills; and (3) the major soil $\mathrm{pH}$ boundary that occurs in the same area.

\section{Stop 26: Milepost D-302, Slope Mountain Dall sheep}

Dall sheep are frequently observed on the west- and south-facing slopes of Slope Mountain, where they are visiting numerous salt licks. If we are lucky we will have good views of the adult sheep and their lambs through spotting scopes.

\section{Massive ice exposures}

Massive ground-ice exposure and wastage occurs at the base of Slope Mountain, with good ice exposures at several sites along the base of the slope (fig. 38). This 
site was visited and cored by Nelson and Outcalt in 1982 (see Brown and Krieg, 1983, p. 183-185).

\section{Stop 27: Milepost D-308, pipeline and construction pad revegetation}

Recovery following pipeline and construction pad revegetation

Intensified growth of shrubs is the result of plantsuccession processes after disturbance in the Low Arctic. This is especially visible in this area where an underground gas pipeline was installed in the early 1980s from Prudhoe Bay to Pump Station 4. Along this section of the Haul Road there are many willows (Salix spp.)

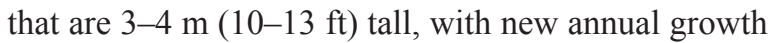
of 30-40 cm (12-16 in) (fig. 39).

Multiple lines of evidence suggest that overall shrub cover is increasing in the Arctic, largely due to warmer summer temperatures and longer growing seasons.
Remote sensing time-series analyses indicate that the two decades following the initial launch of the AVHRR sensors (1981-2001) were a period of rapid increase in the Normalized Difference Vegetation Index (NDVI) at northern latitudes (Myneni and others, 1998; Zhou and others, 2001; Jia and others, 2003). The NDVI is an index of vegetation greenness, and is correlated with vegetation biomass.

Results from long-term warming and fertilization studies suggest an increase in the abundance of deciduous shrubs relative to evergreen shrubs and nonvascular plants (Chapin and others, 1995). In addition to remote sensing and plot level experimental studies, shrub expansion in the Arctic has been observed through analysis of oblique aerial photography. Using this method in northern Alaska, Tape and others (2006) found an increase in alder, willow, and dwarf birch, with the change most easily detected on hill slopes and valley bottoms. Shrub
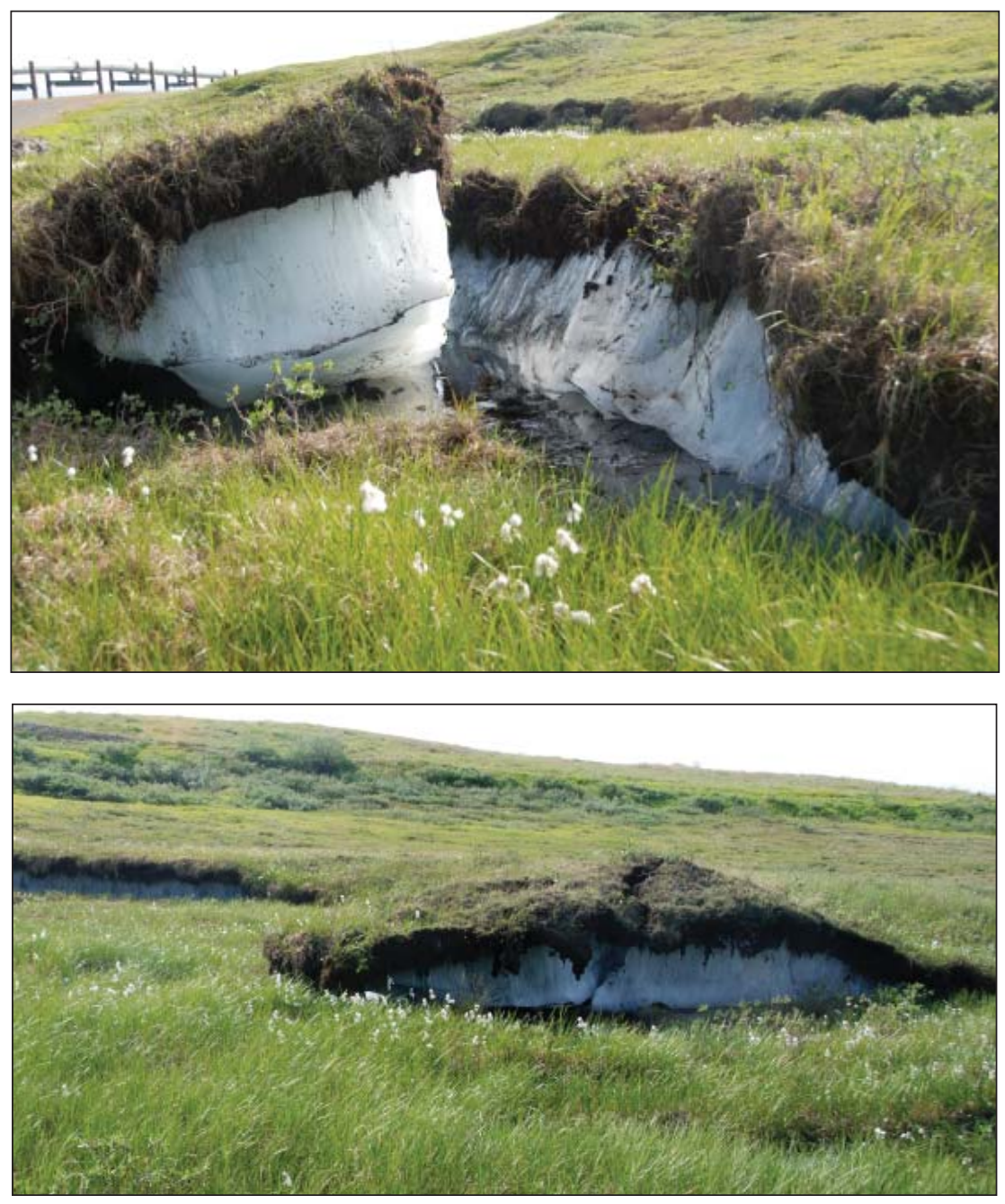

Figure 38. Ice exposed in mound at base of hill at Slope Mountain. Photos by D.A. Walker. 
increase occurred through the expansion of shrub patch boundaries, the filling in of existing patches, and the growth of individual shrubs (Tape and others, 2006).

\section{Terraces of the ancient Sagavanirktok River}

Our route down the Sagavanirktok River valley will take us across the Itkillik II glacial limit east of Slope Mountain, then across outer and inner end-moraine belts of Itkillik I age north of Happy Valley. Older end moraines, assigned to the Sagavanirktok and Anaktuvuk glaciations, extend into the valley center farther north. Our route will cross drift of the middle Pleistocene Sagavanirktok glaciation, but more ancient moraines farther downvalley have been broadly eroded since their deposition. The Dalton Highway follows younger outwash terraces incised within those ancient moraine remnants.
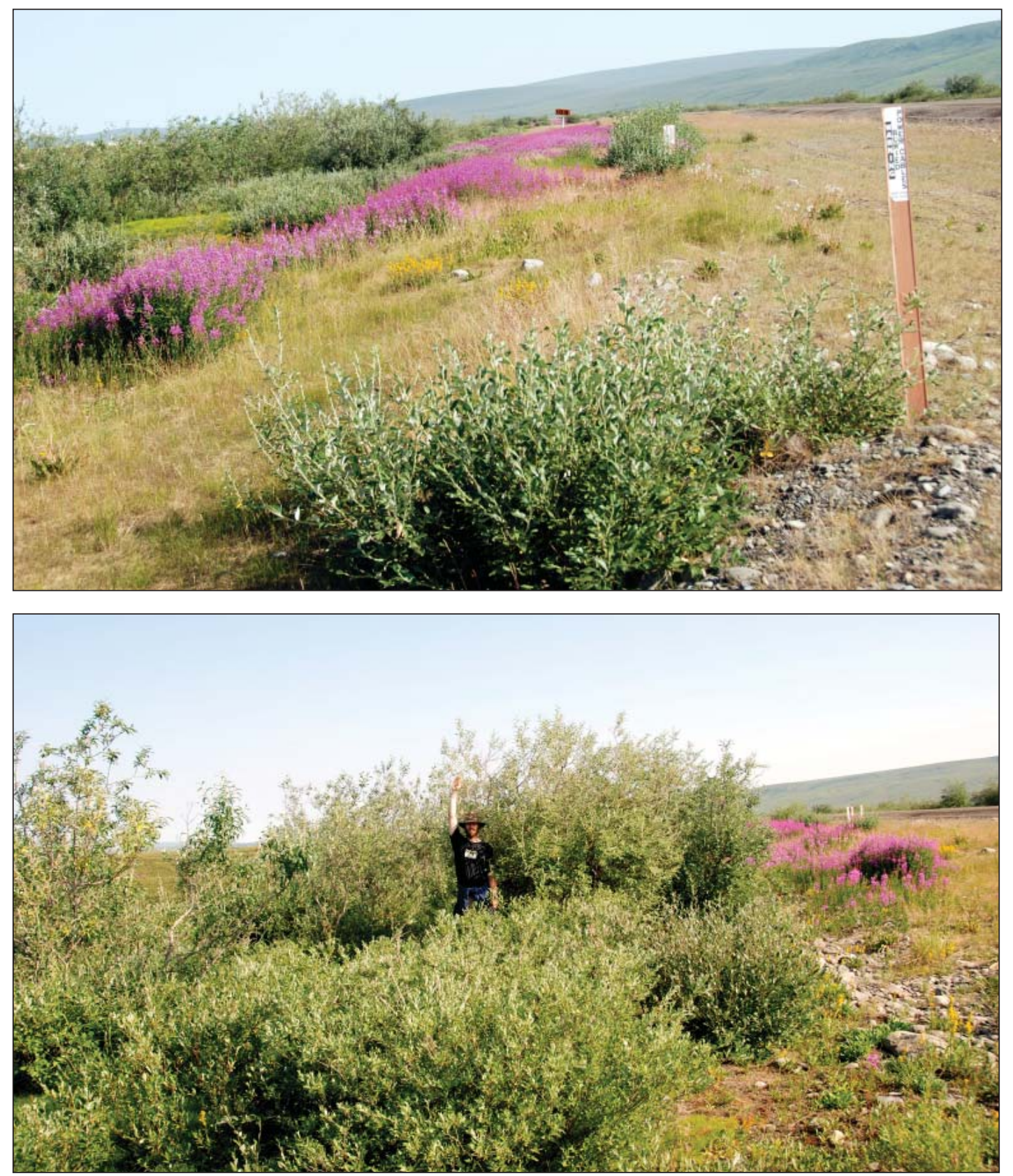

Figure 39. (Top) Revegetated buried pipeline berm and (bottom) gasline trench near MP 308. Note height of willows is more than $3.5 \mathrm{~m}$ with more than $50 \mathrm{~cm}$ of branch growth in summer 2007. Photos by D.A. Walker. 


\section{Stop 28: Milepost D-325, Uplands south of Happy Valley (optional) \\ Happy Valley cut}

The road ascends from the floodplain of the Sagavanirktok River onto the adjacent uplands at the Happy Valley roadcut (fig. 40). The cut exposed muck and peat with massive ground ice above glacial till resting on bedrock. A full explanation of the history of the road cut, a geologic cross section, and a photograph taken at the time the section was exposed are in Brown and Kreig (1983, p. 188-191). The dam at the base of the hill was constructed to contain flow of material from the road cut.

\section{Northern foothills: Colluvial basins and water tracks}

Between the Happy Valley road cut and the Happy Valley research area, there are numerous views to the west of typical Arctic foothills terrain, including colluvial basins (flat-floored upland depressions, which are partially filled with ice-rich peat, organic-rich slopewash deposits, and colluvium, and often contain thaw lakes and high-centered ice-wedge polygons) (fig. 41). See Brown and Kreig, 1983, p. 191.

Thermokarst and erosion is evident along the gas pipeline, and particularly noticeable at Milepost D-333.

\section{Stop 29: Milepost D-336, Happy Valley camp and research site}

The Happy Valley camp (Brown and Kreig, 1983, p. 192) has been a site of numerous research projects.

\section{Arctic Flux Study}

The Arctic Flux Study, funded by the National Science Foundation, utilized the extensive areas of typical tussock tundra terrain for monitoring trace gas fluxes. Measurements of net ecosystem $\mathrm{CO}_{2}$ exchange (NEE) and energy balance were made using chamber-, tower-, and aircraft-based measurement techniques during the 1994-1995 growing seasons (June-August) (Oechel and others, 1998). The objectives were to quantify the interrelationships between NEE and the energy balance measurements made from different sampling techniques. Qualitative and quantitative intercomparisons revealed that on average the correspondence between the mass and energy fluxes measured by these sampling methods was good despite potential spatial and temporal mismatches in sampling scale. The correspondence among the chamber-, tower-, and aircraft-measured fluxes varied both seasonally and interannually, suggesting the lack of a consistent bias between the sampling techniques. Even with the numerous sources of potential variation, the results reveal that the various methods give comparable estimates of NEE and energy flux.

\section{CALM studies}

Happy Valley was one of the Circumpolar Active Layer Monitoring (CALM) program's original installation sites in northern Alaska. The ARCSS/CALM grid at Happy Valley is one of five $1 \times 1 \mathrm{~km}(3.3 \mathrm{ft} \times 3.3 \mathrm{ft})$ arrays of precisely surveyed sampling grids in the Kuparuk region. Grids were set up at Toolik Lake and Imnavait

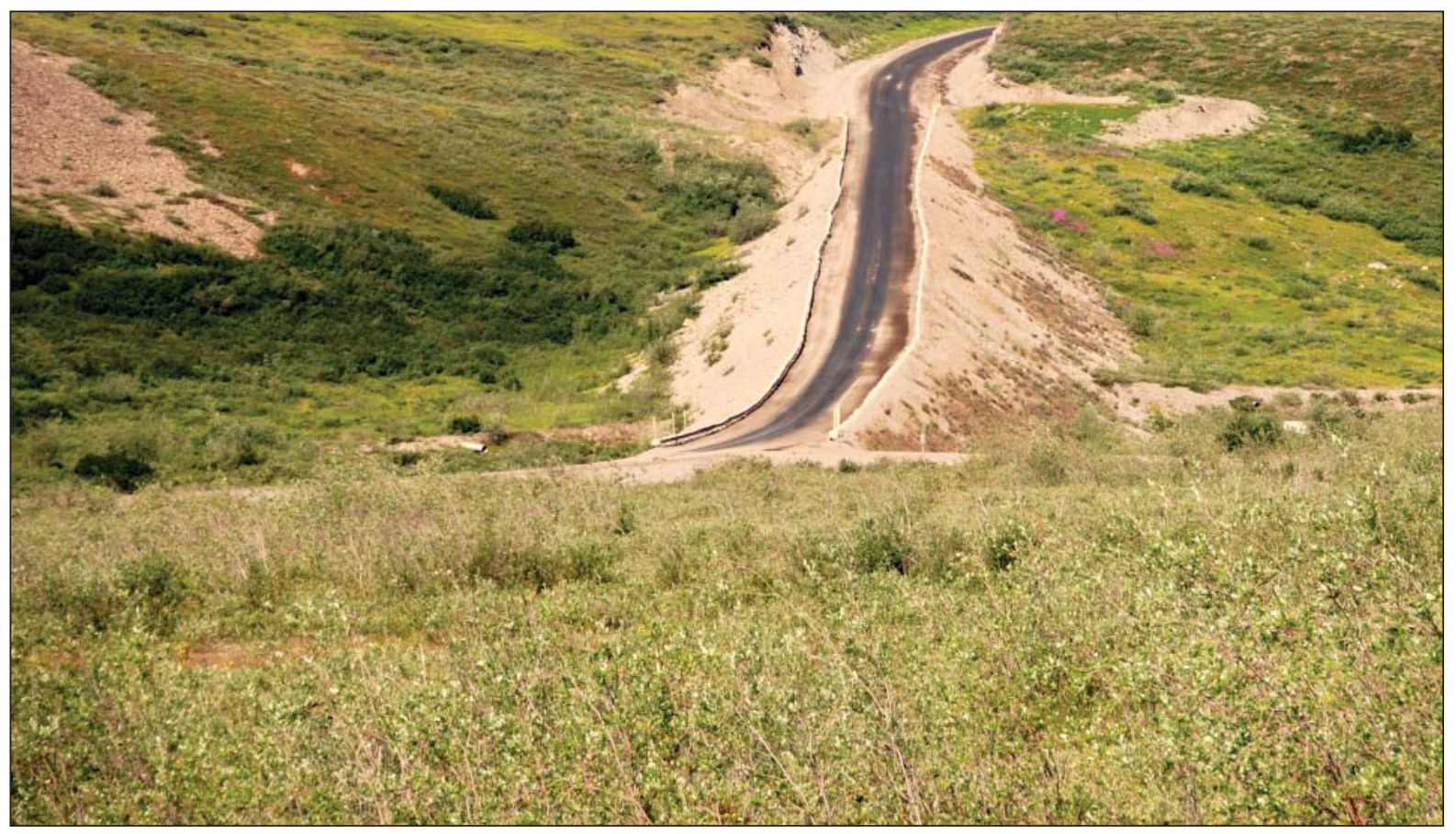

Figure 40. Happy Valley road cut. Photo by D.A. Walker, July 2007. 
Creek under the U.S. Department of Energy R4D program during the late 1980s, and at Happy Valley, West Dock, and Betty Pingo under NSF's Arctic Flux Study (Weller and others, 1995) in the mid 1990s.

CALM is a global-change monitoring program concerned with the dynamics of the active layer and upper permafrost, and with long-term trends in temperature, thaw subsidence, and active-layer thickness. During the Arctic Flux studies in the mid-1990s, the overarching goal of active-layer investigations was to obtain accurate regional estimates of the volume of thawed soil in the Kuparuk region. Recent Alaskan investigations under the CALM II program (2004-09) have focused on monitoring thaw subsidence accompanying thaw penetration into the permafrost underlying the active layer.
The Happy Valley site has also been used extensively to investigate topoclimatic influences on active-layer thickness. The ARCSS/CALM grids encompass specific combinations of landscape elements, chosen to provide integrated and representative examples of local topographic, vegetative, geomorphic, and edaphic conditions. See Appendix C for a more complete description of the CALM studies at Happy Valley and elsewhere.

\section{Patterned-ground research (also see Stop 31)}

Patterns of small polygons, circles, and hummocks are common across northern Alaska and into northern Canada (fig. 42). These patterns are most apparent in the northern part of the Low Arctic, such as at Prudhoe Bay and Barrow. Patterned-ground ecosystems were
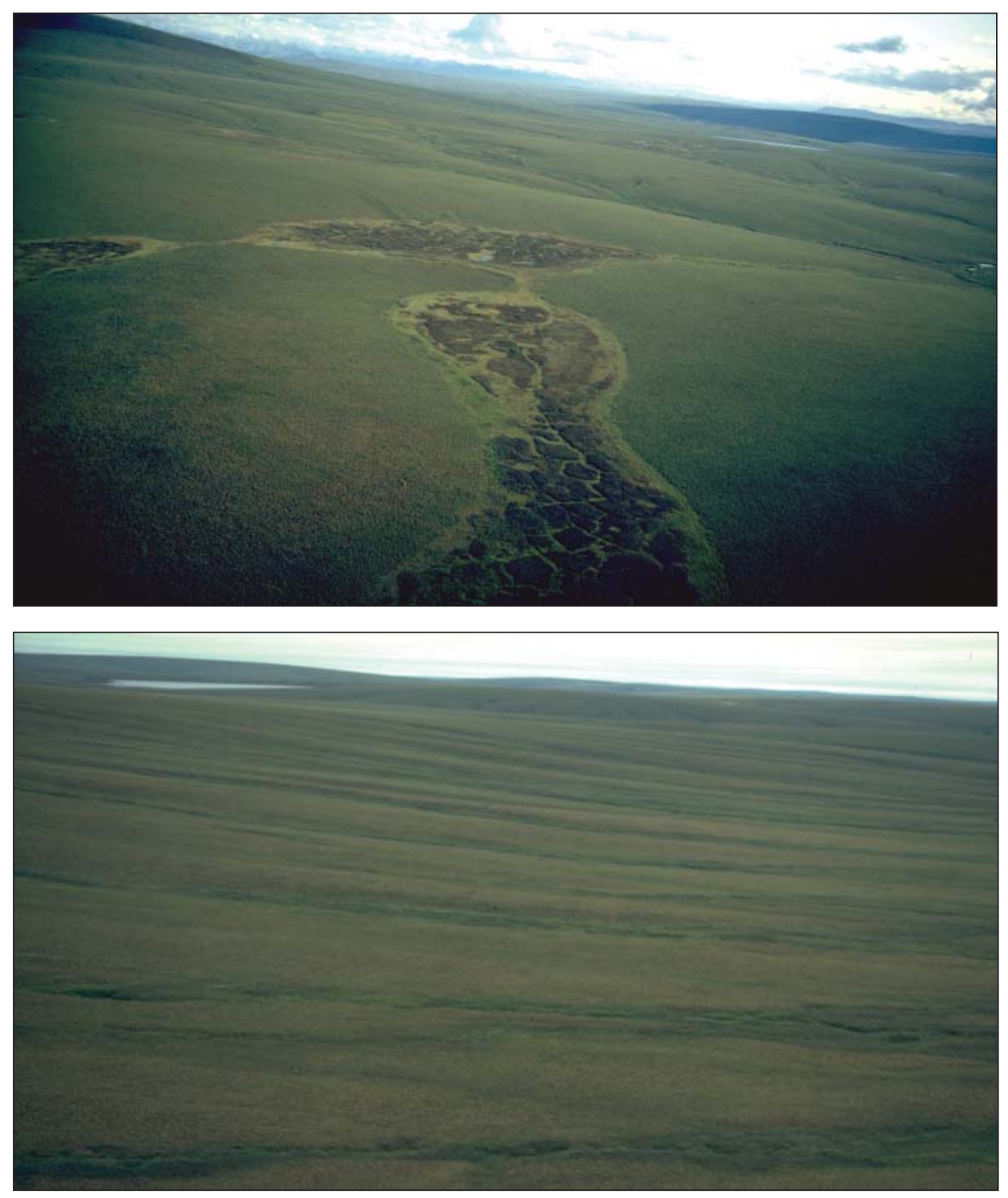

Figure 41. Typical landforms in the Northern Foothills Physiographic Province. (Top) Colluvial basins. (Bottom) Well-developed upland water tracks. Photos by D.A. Walker. 


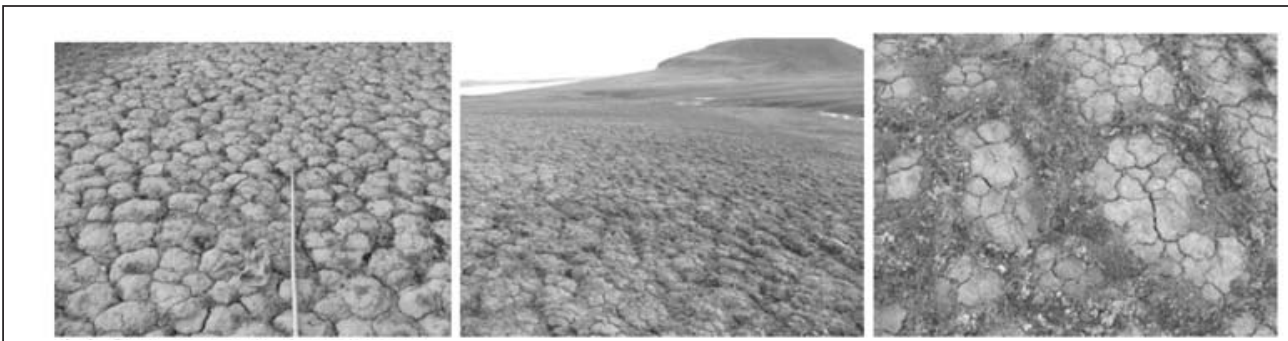

(a) Subzone A, Isachsen
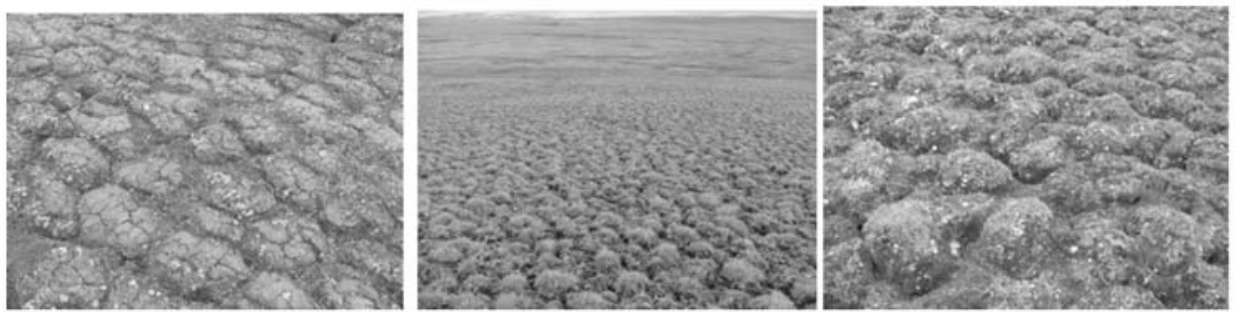

(b) Subzone B, Mould Bay
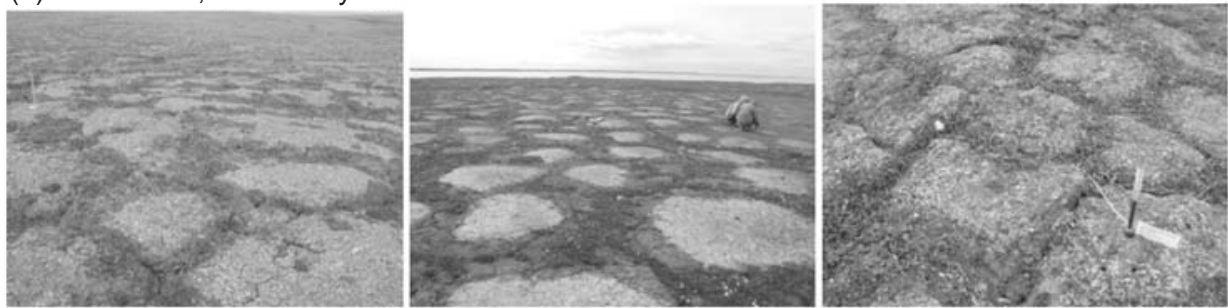

(c) Subzone C, Green Cabin (left) and Howe Island (center and right)

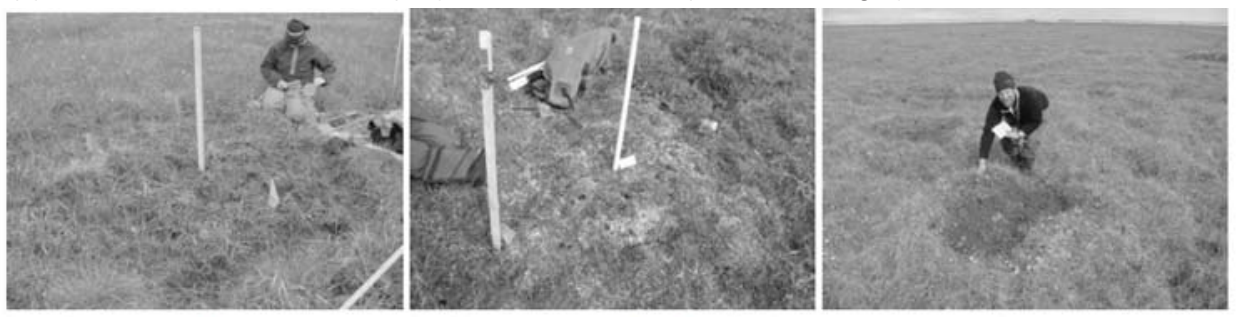

(d) Subzone D, Deadhorse (left) and Franklin Bluffs (center and right)
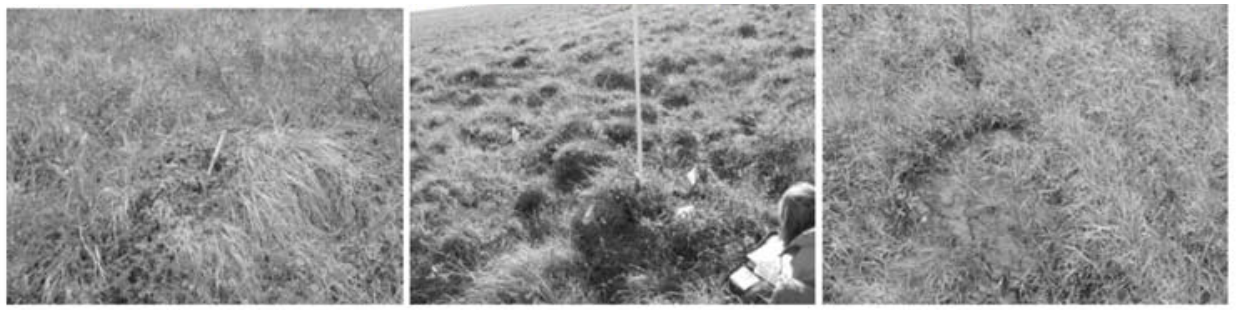

(e) Subzone E, Happy Valley
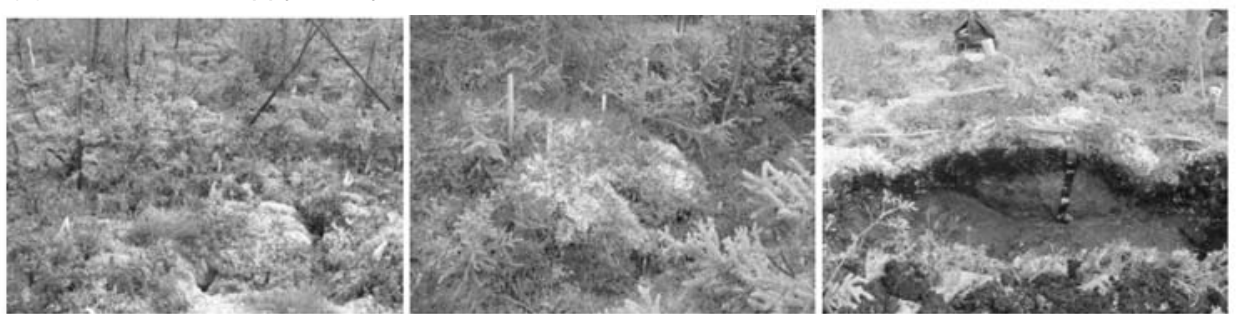

(f) Boreal Forest, Inuvik

Figure 42. Patterned ground forms along the Arctic bioclimate gradient. (Modified from Walker and others, 2008.) 
examined in all five Arctic bioclimate subzones along an $1,800 \mathrm{~km}(1,120 \mathrm{mi})$ trans-Arctic temperature gradient in northern Alaska and northwestern Canada, as part of an NSF-sponsored Biocomplexity of Patterned Ground project (Walker and others, 2008). Happy Valley (fig. 43) is the southernmost site along the Alaskan portion of the Arctic transect (fig. 44). The trends in climate, vegeta- tion, soils, active-layer depth, and frost heave along the climate gradient are shown in figure 45 . The $n$-factor is an index of the total insulative effect of the soil organic horizons, vegetation, and snow. In summer the $n$-factor is strongly correlated with the thickness of the plant canopy and the soil organic horizons (fig. 46). In winter the $n$-factor is highly correlated with the depth of the
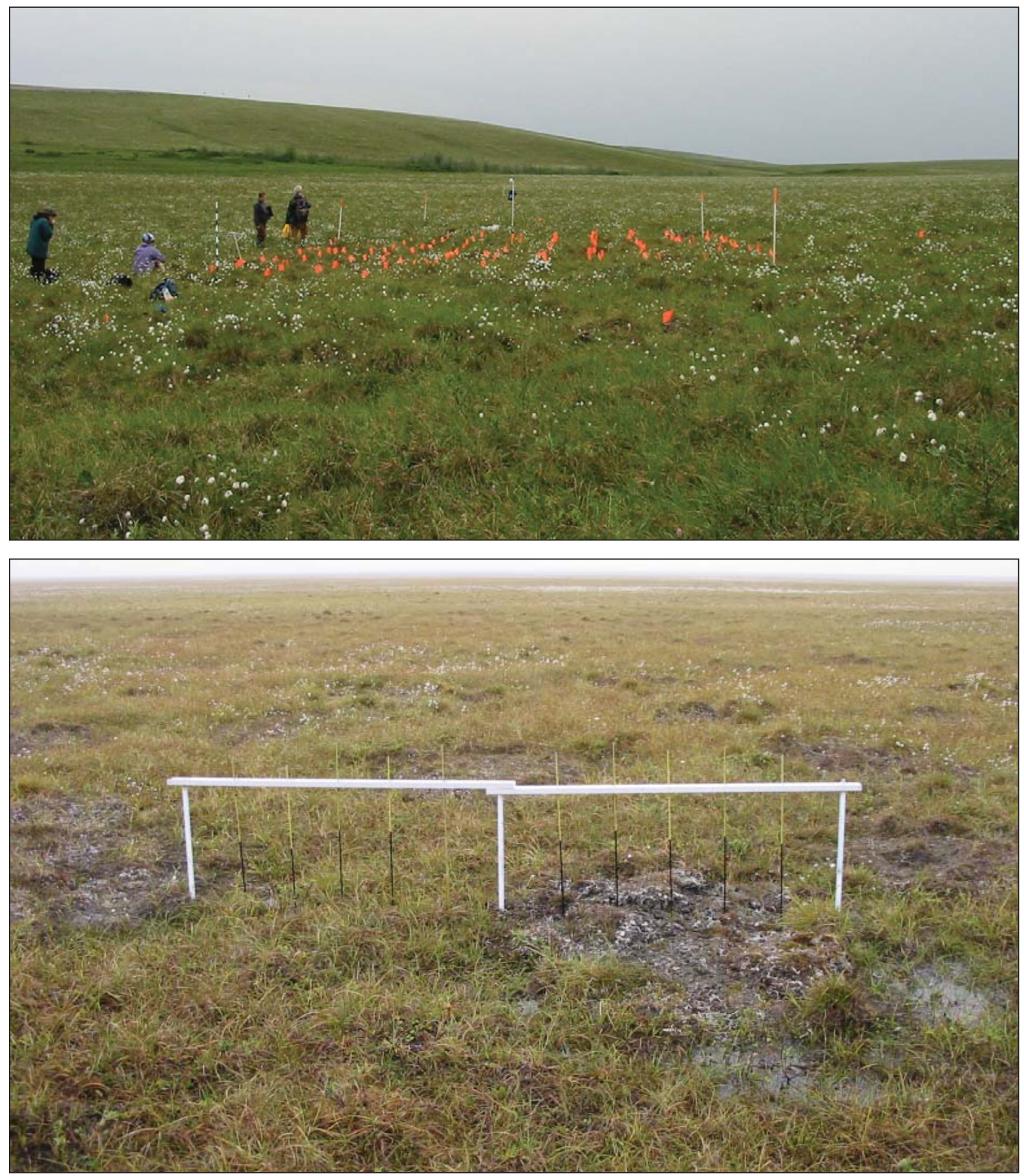

Figure 43. (Top) Monitoring grid for biocomplexity of patterned ground study at Happy Valley. (Bottom) Device for monitoring soil heave at Deadhorse site. Photos by J.K. Knudson. 
Figure 44. Study locations within the five Arctic bioclimate subzones (CAVM Team and others, 2003). The subzones are defined by a combination of summer temperatures and the character of the vegetation. Approximate mean July temperatures within each subzone are: $A=0-3^{\circ} \mathrm{C}, B$ $=3-5^{\circ} \mathrm{C}, \mathrm{C}=5-7^{\circ} \mathrm{C}, \mathrm{D}=7-9^{\circ} \mathrm{C}$, $E=9-12^{\circ} \mathrm{C}$.

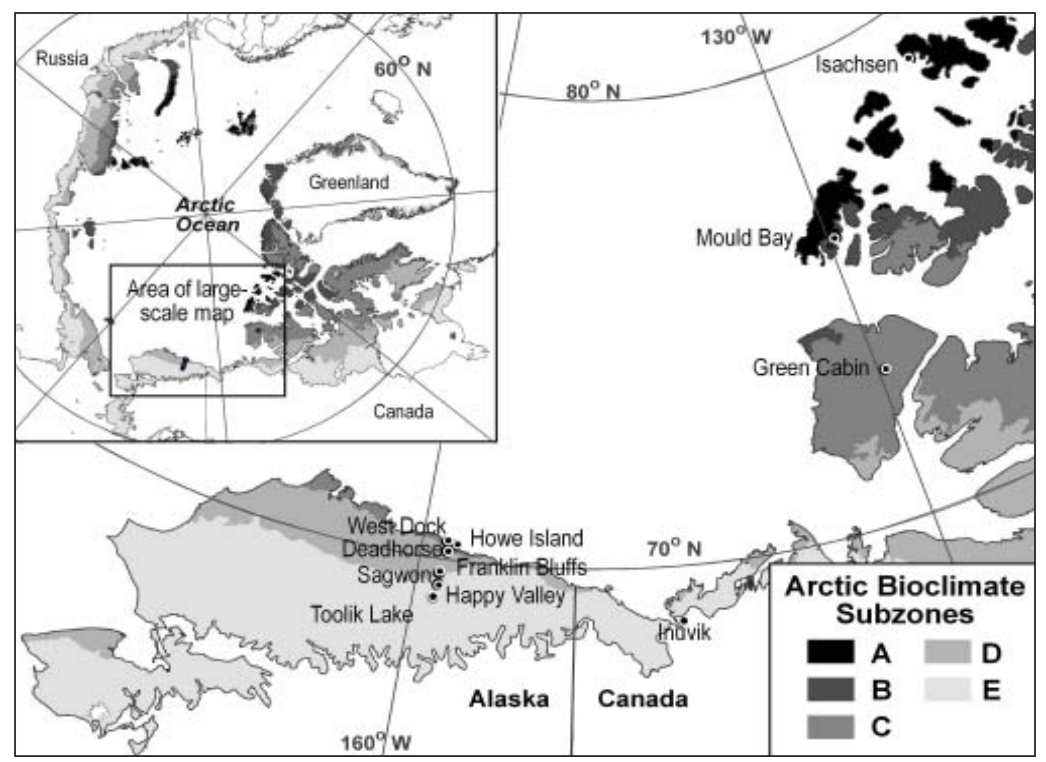

snow pack. Experiments that have removed and added vegetation to nonsorted circles have confirmed the strong effect that vegetation has on both soil heave and the active-layer thickness (Kade and Walker, 2008).

Soil temperature differences between the poorlyvegetated centers and well-vegetated margins of the patterned-ground features (PGFs) drive the movement of water, affect the formation of aggradation ice, promote differential soil heave, and regulate a host of system properties that affect the ability of plants to colonize the centers of these features. A variety of models have been developed to help explain the processes involved in patterned-ground formation, including models of (a) the thermo-mechanical processes within individual non-sorted circles (Nicolsky and others, 2008), (b) the self-organization of nonsorted circle landscape through spontaneous differential heave (Peterson and Krantz, 2003, 2008), and (c) the formation of patterned ground through feedback interactions between vegetation and the hydrological-thermal processes (Daanen and others, 2007).

Climate differences along the north-south Arctic transect cause major differences in the patterned-ground types occurring on zonal sites (figs. 42, 47). In the High Arctic, cracking is the dominant process, resulting in small- and medium-size nonsorted polygons. Farther south, the dominant genetic factor is differential frost heave, which results in nonsorted circles and mediumsize hummocks. Vegetation plays a key role affecting the morphology of nonsorted PGFs by insulating the soil surface and decreasing the heat flux from the soil, stabilizing the soil with roots, developing organic soil horizons, and masking and effectively smothering the effects of cracking and heaving. In the middle parts of the Arctic (bioclimate subzones C and D), large soil-tem- perature differences occur between the relatively poorly vegetated centers and well-vegetated margins of PGFs. These temperature differentials control the flow of heat and water within PGFs, and promote the development of differential frost heave and aggradation ice.

\section{Stop 30: Milepost D-348, Sagavanirktok River icing}

A large aufeis deposit occurs along the right side of the road. See description of Stop 19 and Yoshikawa (2007) for more information on aufeis deposits.

\section{Stop 31: Milepost D-356, Sagwon climate station and biocomplexity research site}

The transition from the Arctic foothills to the Arctic coastal plain is an important physiographic, climate, soil, and vegetation boundary on the North Slope. To the north, Franklin Bluffs, the White Hills, numerous thaw lakes, and Pump Station 2 are visible from this location, and to the south the rolling foothills stretch to the Brooks Range. From space, a very noticeable boundary just north of here demarcates a major transition from primarily acidic tundra south of here to nonacidic tundra to the north. This area is an important research site for several projects. CRREL has had a climate station here since the road was built in 1974 (fig. 48). Most recently the Biocomplexity of Patterned Ground project has examined the substrate transition in more detail.

The vegetation at this site is Moist Acidic Tundra (MAT). The MAT site is covered by tussock tundra (Sphagno-Eriophoretum) with few ( $<1$ percent cover) nonsorted circles apparent at the surface. Soils investigations have shown that circle patterns are present but often masked by surface vegetation (Ping and others, 2008). This vegetation type is dominated by dwarf shrubs (for 
(a)

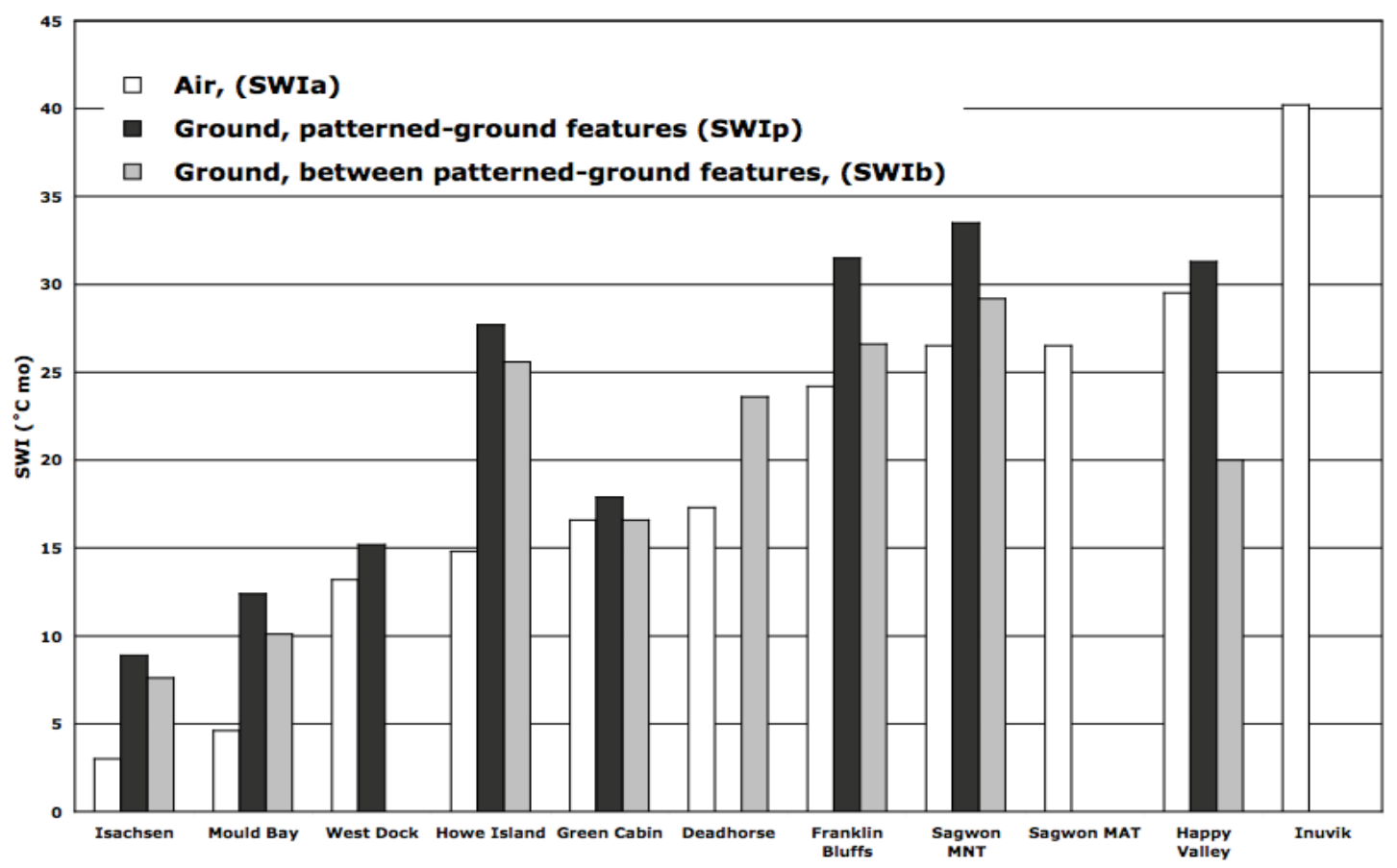

(b)

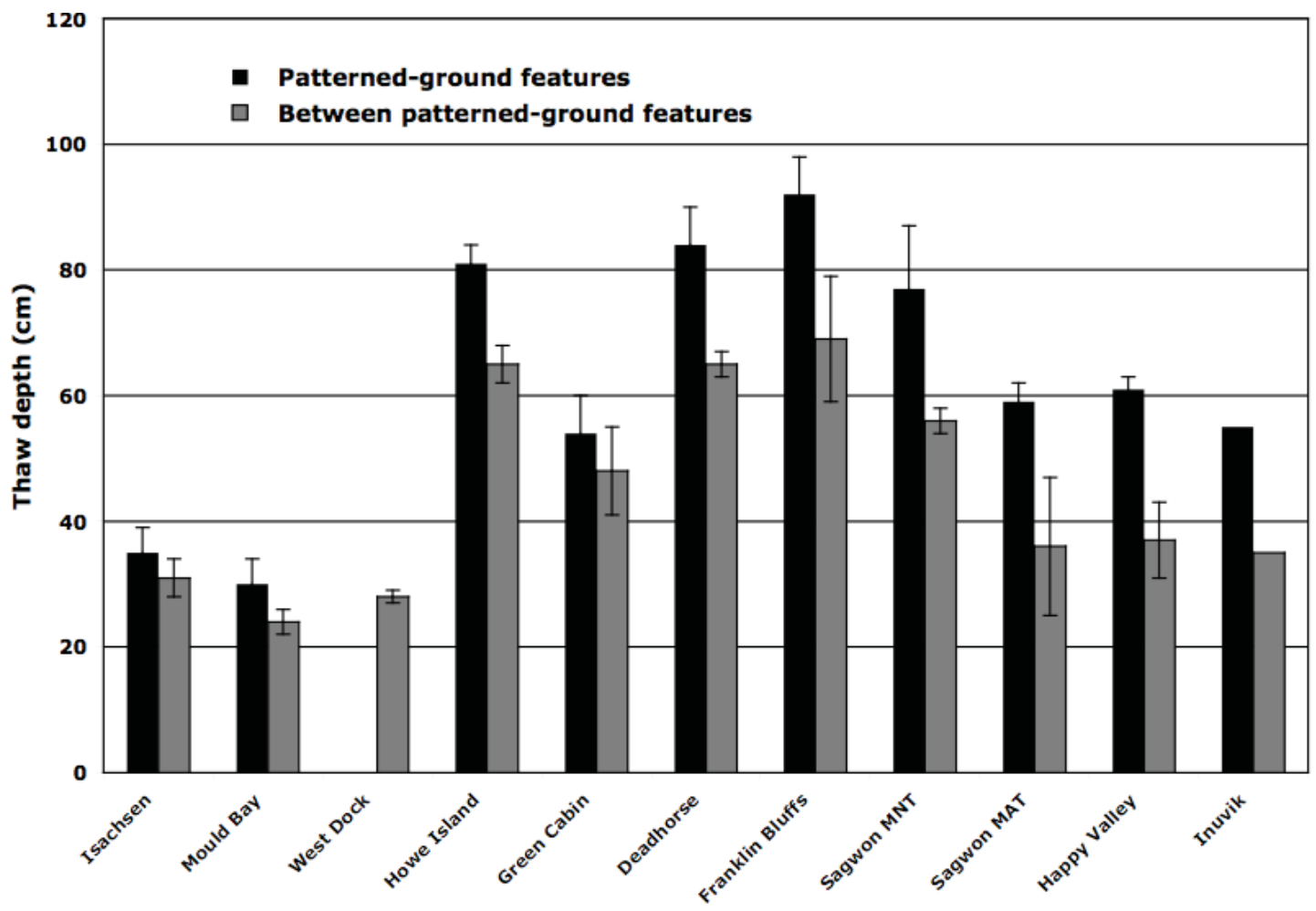

Figure 45. Trends in (a) temperature, (b) active layer, (c) frost heave, (d) biomass, and (e) thickness of vegetation, moss, soil organic layer, and snow along the North American Arctic Transect on and between patterned-ground features. (Modified from Walker and others, 2008.) 
(c)

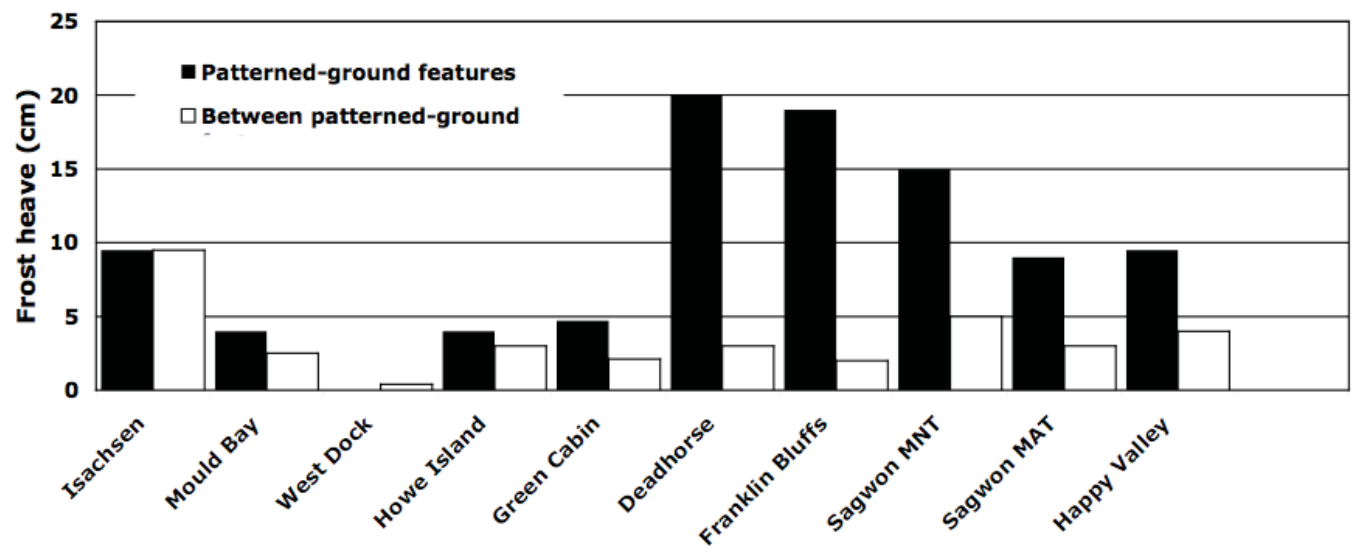

(d)

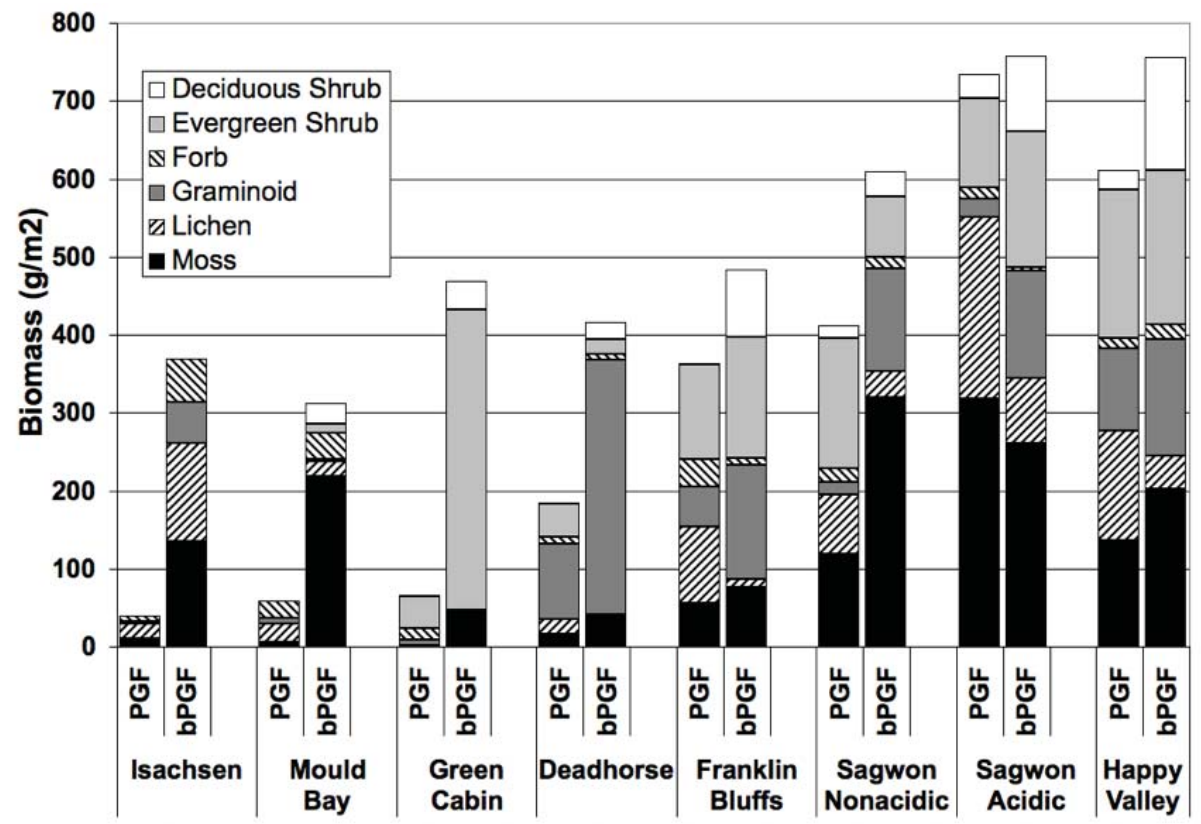

(e)

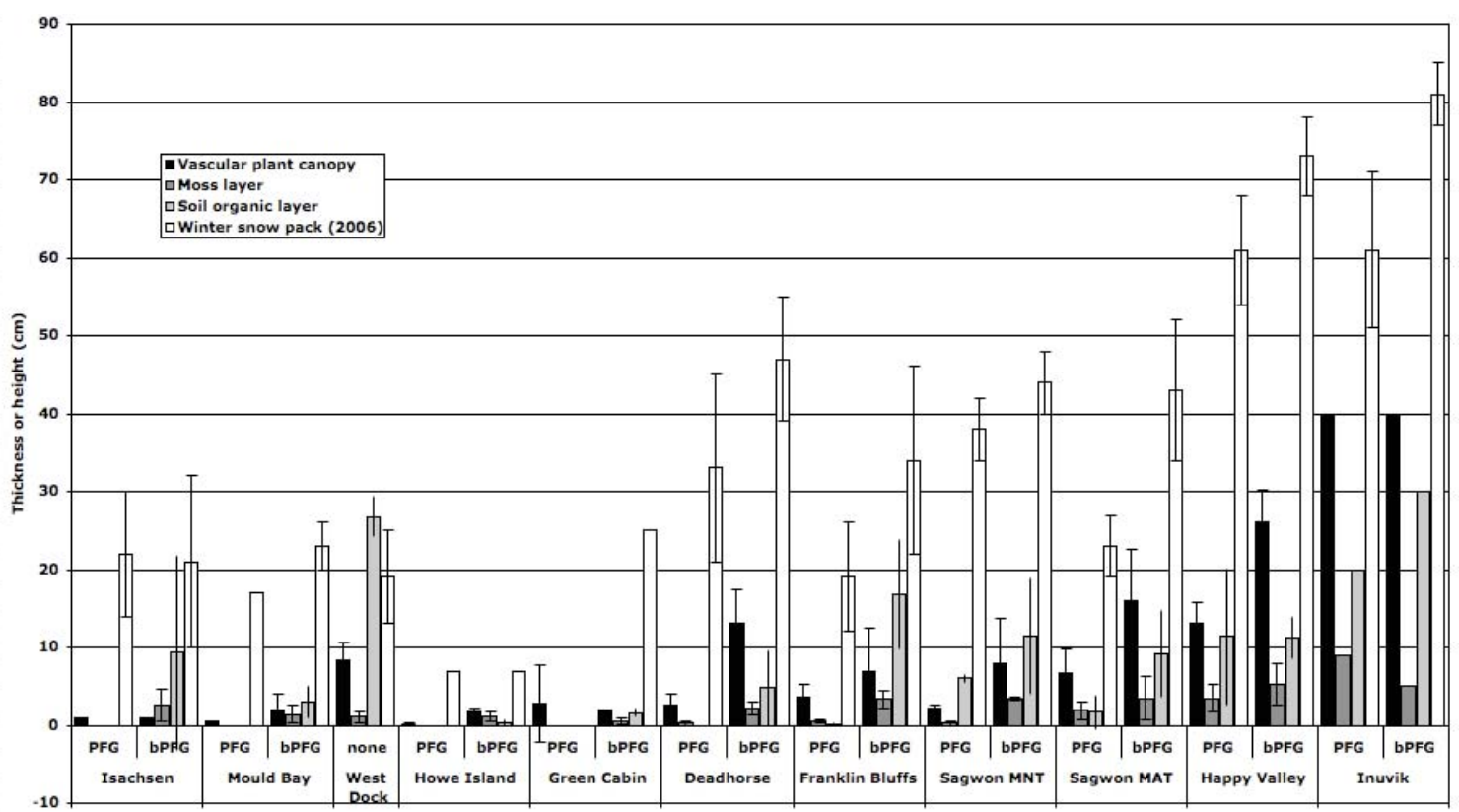


example Betula nana, Ledum palustre ssp. decumbens, Salix pulchra), tussock sedges (Eriophorum vaginatum), and acidophilous mosses (Sphagnum spp., Aulacomnium spp., Polytrichum spp., and Dicranum spp.). Soils of MAT have a thick, continuous organic horizon over gleyed subsoil material and contain cryoturbated organic material in the lower part. Both the MAT and MNT sites are on silty loess deposits. Soil $\mathrm{pH}$ of MAT sites tends to increase with depth from about 4.0 at the surface to 6.5 in the frozen $\mathrm{C}$ horizons.

\section{Stop 32: Milepost D-357, acidic/nonacidic tundra boundary}

Effects of a soil pH boundary on ecosystem properties (summarized from Walker and others, 1998)

In 1995 and 1996, ecosystem properties were studied on either side of an important soil $\mathrm{pH}$ boundary (Walker and others, 1998). The $\mathrm{pH}$ boundary extends at least 300 $\mathrm{km}(190 \mathrm{mi})$ to the east and west of here and is obvious from space (fig. 49), but not so obvious on the ground. An abundance of nonsorted circles and relatively low shrub biomass (202 vs $85 \mathrm{~g} \mathrm{~m}^{-2}$ ) north of the boundary results in the lighter tones on the north side of the boundary on false-color infrared satellite images. The boundary separates nonacidic $(\mathrm{pH}>6.5)$ ecosystems to the north from predominantly acidic $(\mathrm{pH}<5.5)$ ecosystems to the south. Loess blankets much of the Arctic coastal plain and Arctic foothills, and both MAT and MNT occur on these extensive deposits, so it is difficult to explain the sharp boundary solely by differences in surface deposits. The boundary may be partially due to a stronger winter arctic climate north of the topographic barrier of the Arctic foothills. A colder, windier climate with shallower snowpack would promote the formation

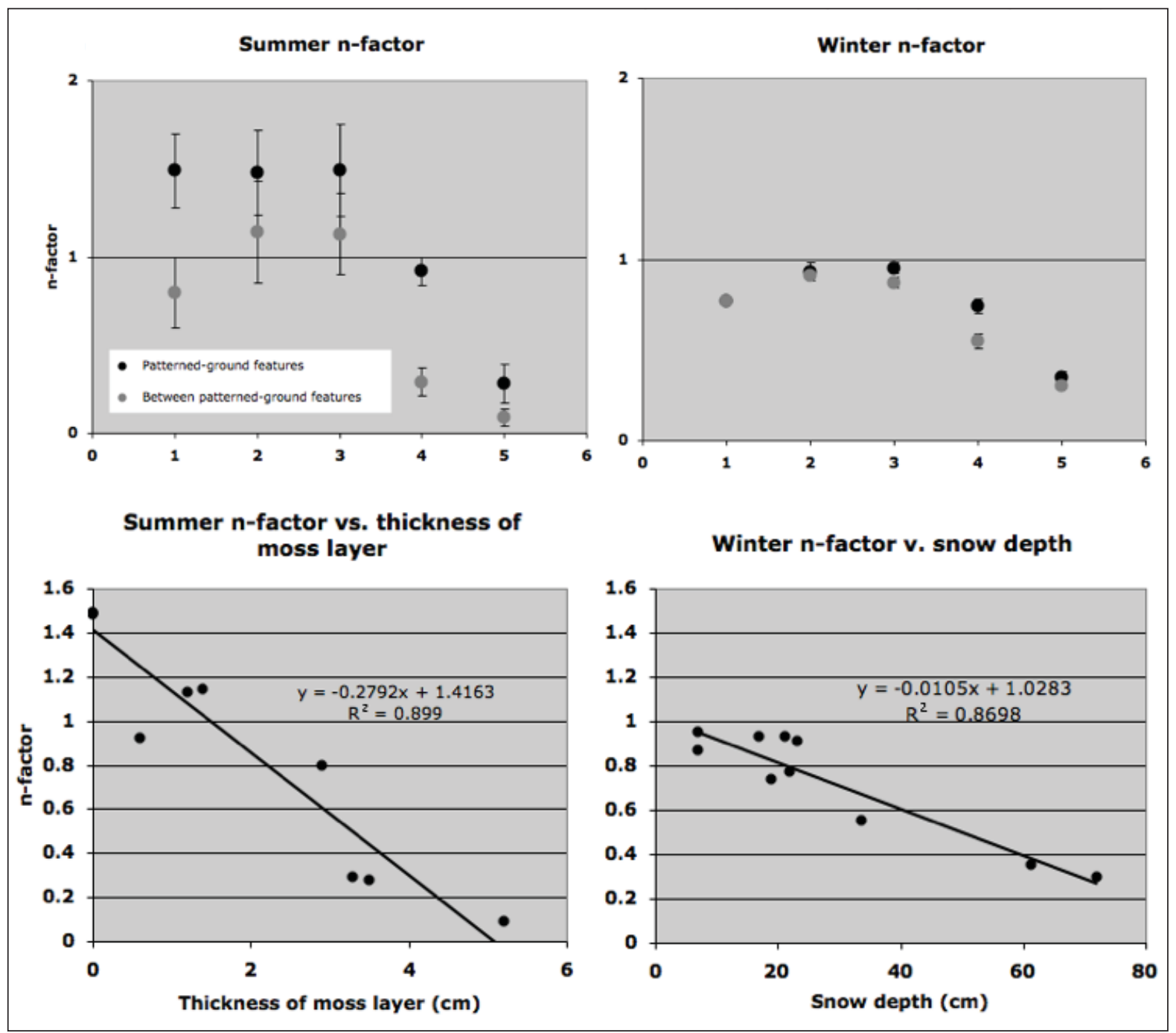

Figure 46. (Top) Mean ( \pm s.d.) summer and winter $n$-factors at representative sites in each subzone along the North American Arctic Transect. (Bottom left) Summer n-factor vs. thickness of the green moss layer; (bottom right) and winter n-factor vs. snow depth measured in May 2006 (right) (Walker and others, 2008). 


\section{Dominant processes}

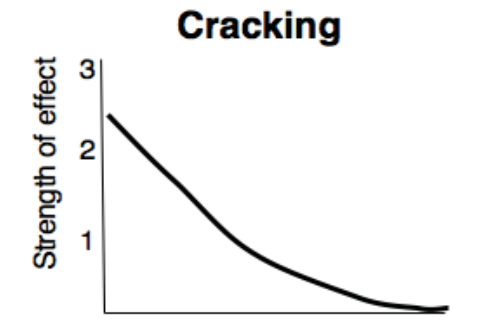

A B C D E BF

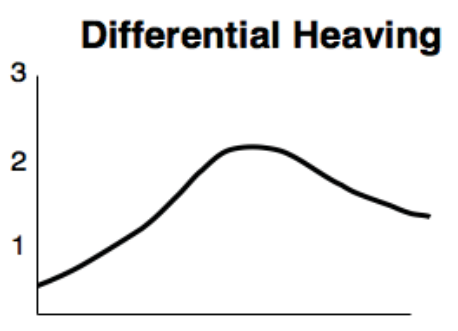

A B C D E BF Bioclimate Subzone

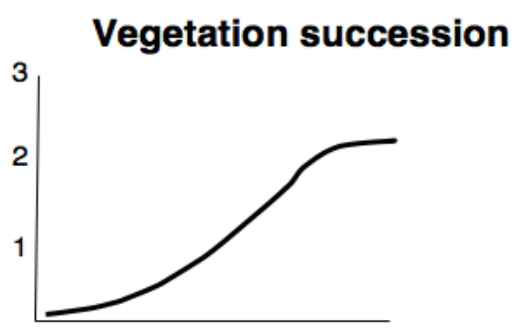

A B C D E BF

\section{Dominant patterns}

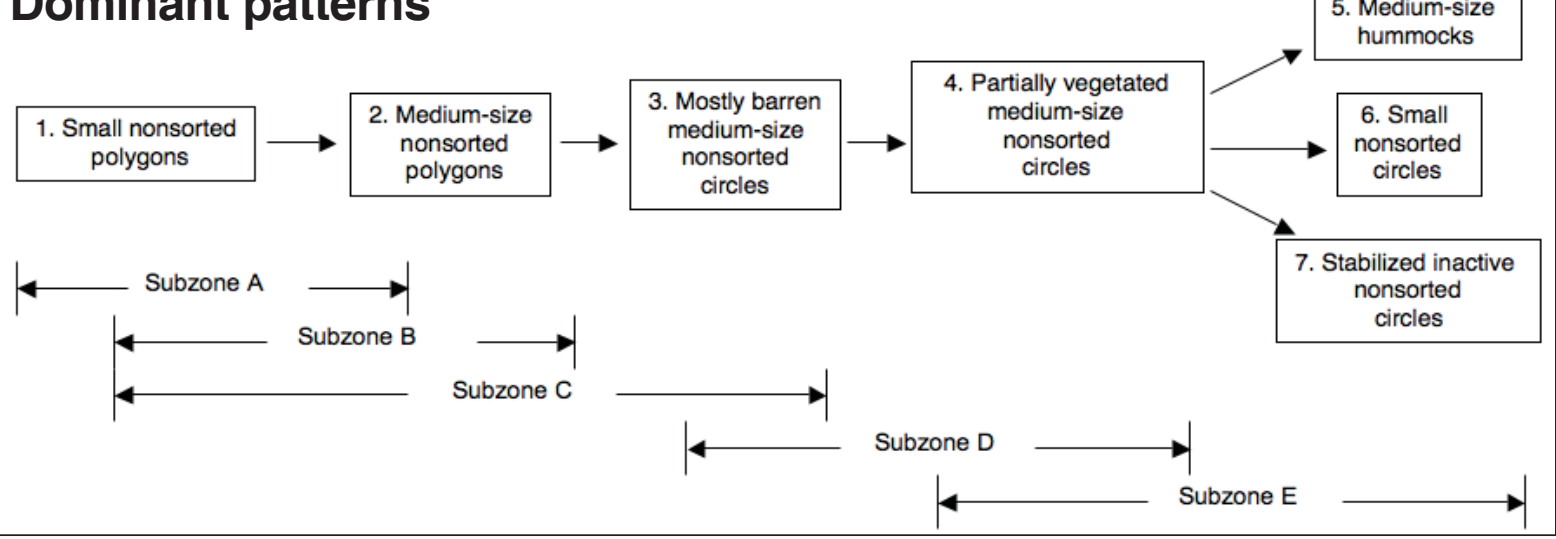

Figure 47. (Top) Dominant genetic processes and patterns (bottom) involved in patterned-ground formation on zonal sites along the Arctic bioclimate gradient. (From Walker and others, 2008.)

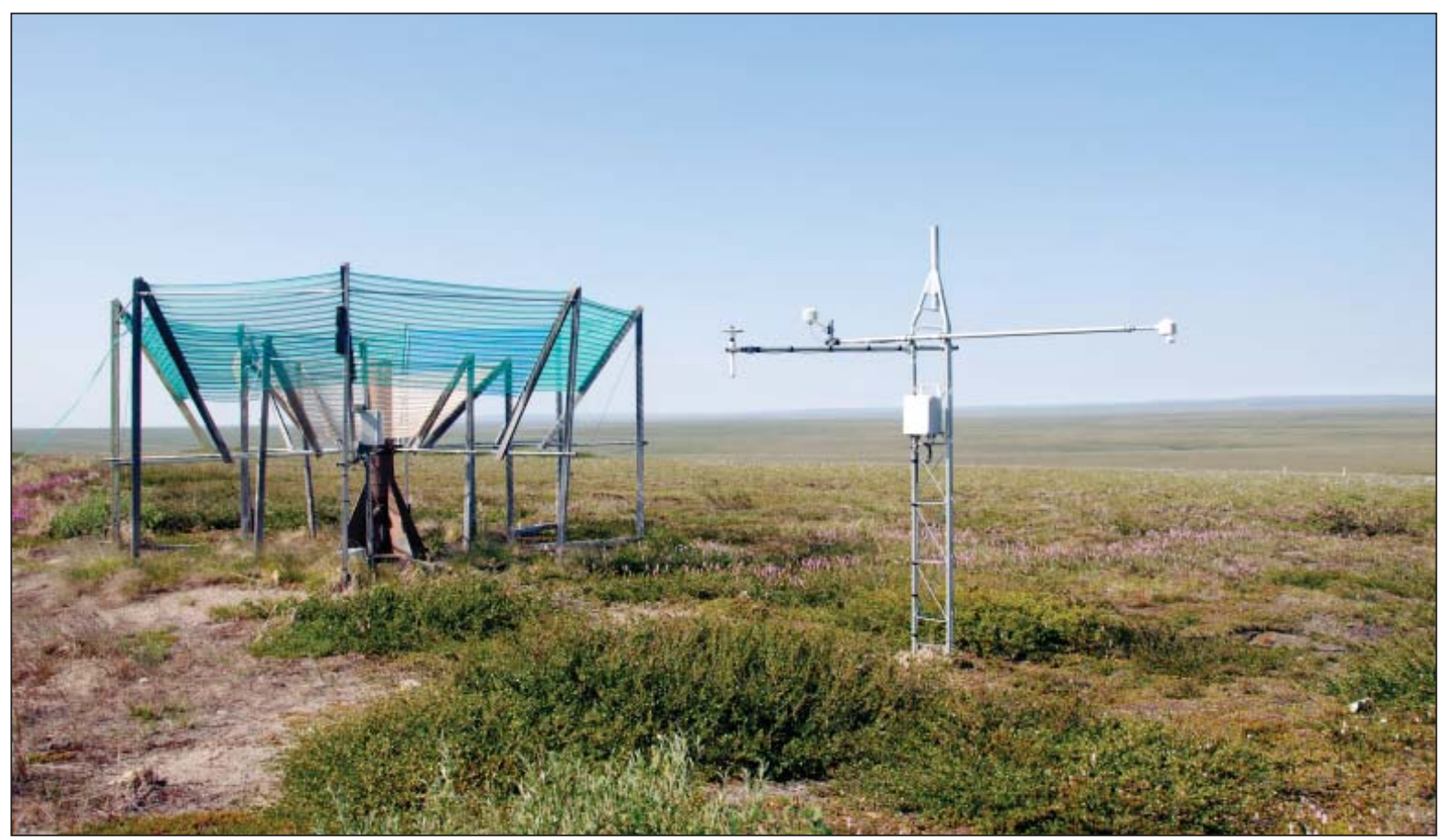

Figure 48. Wyoming snow gauge and climate monitoring site at Sagwon. Photo by D.A. Walker. 


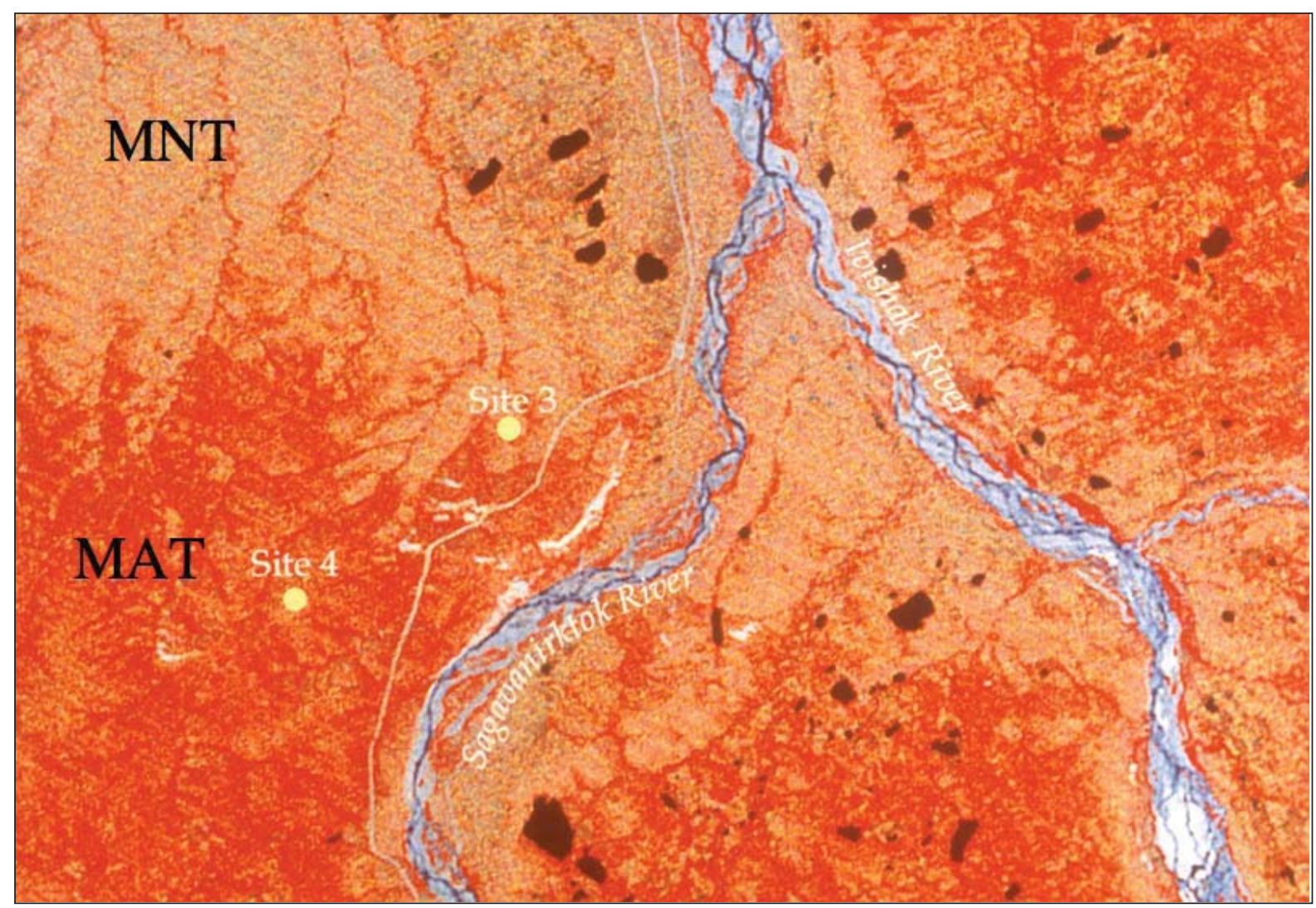

Figure 49. MNT/MAT boundary on Landsat image of Sagwon area (light vs. dark red). The boundary stretches across the northern Alaska Foothills/coastal plain boundary (Walker, unpublished).

of nonsorted circles and cause the continual stirring of nonacidic subsoils to the surface.

Ground-based studies of Moist Acidic Tundra (MAT) (fig. 50, top) and Moist Nonacidic Tundra (MNT) (fig. 50, bottom) ecosystems were conducted at two intensive study sites about $3 \mathrm{~km}(2 \mathrm{mi})$ apart on either side of the boundary. The MAT site was similar to the site at Stop 31. The vegetation at Stop 34 is MNT, similar to the MNT site used in the study, located about $1.5 \mathrm{~km}(1 \mathrm{mi})$ west of this point. Tables 5-9 contrast the properties of MAT and MNT at the two study sites. The MNT site had lower shrub biomass, lower leaf-area index (LAI), and lower normalized difference vegetation index (NDVI). It also had high cover (36 percent) of nonsorted circles. The nonsorted circles are partially vegetated patches of highly frost-active soils that are

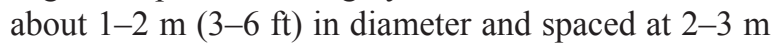
$(6-10 \mathrm{ft})$ intervals; bare soil covers about 4 percent of the MNT site. The plant community between the circles is Dryado integrifoliae-Caricetum bielowii, which is dominated by nontussock sedges (Carex bigelowii, C. membranacea, Eriophorum triste), prostrate shrubs (Dryas integrifolia, Salix arctica, S. reticulata, Arctous rubra), and minerotrophic mosses (Tomentypnum nitens, Hylocomium splendens, Ditrichum flexicaule). Soils of MNT sites have a broken organic layer over a dark-colored A horizon with high base saturation, over a gleyed $\mathrm{C}$ horizon. All soil horizons have consistently high $\mathrm{pH}(>6.5)$ and are strongly cryoturbated (fig. 51, tables $7,8,9)$.

The vegetation and soil differences between MAT and MNT have important consequences for land-atmosphere exchanges (table 5). The MNT site had 28 percent more soil heat flux during 10 days of observation and 54 percent deeper end-of-summer thaw than the MAT site. Summer thaw depths of MNT are consistently deeper than those of MAT throughout the Kuparuk River basin (Nelson and others, 1997), despite MNT being dominant in the northern, colder portion of the study area. This is due to shorter, more open plant canopies (less shading by vascular-plant leaf area), less continuous moss cover, and thinner organic horizons of the MNT (table 6). The MAT site also had about twice the gross photosynthesis and three times the respiration of the MNT site, and greater net carbon gain than the MNT site during the same 10-day measurement period (table 6), despite the close proximity of the two sites and nearly identical temperature, net radiation, and relative humidity. These 

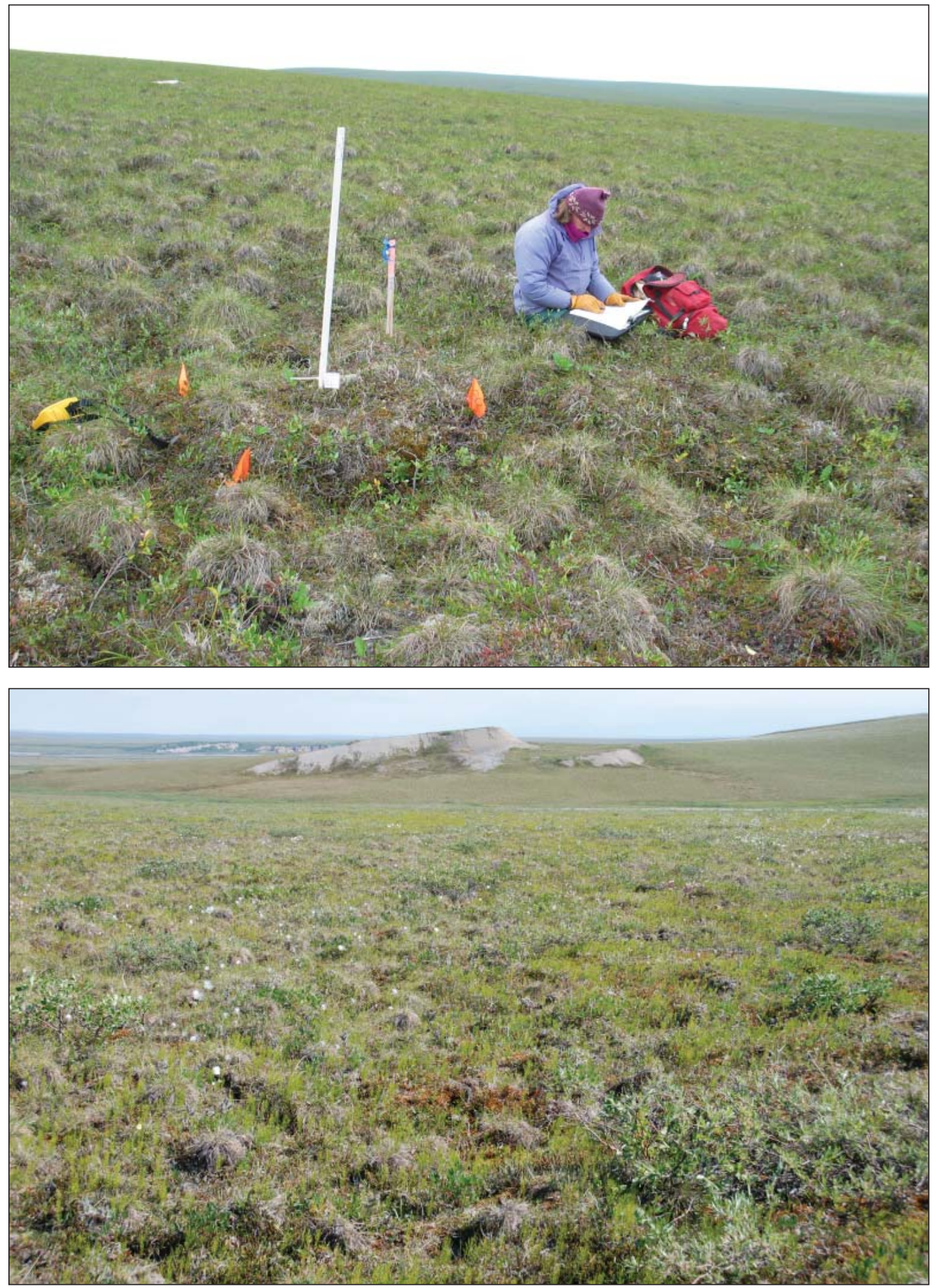

Figure 50. (Top) Moist Acidic Tundra and (bottom) Moist Nonacidic Tundra at Sagwon pH boundary. Photo by D.A. Walker. 

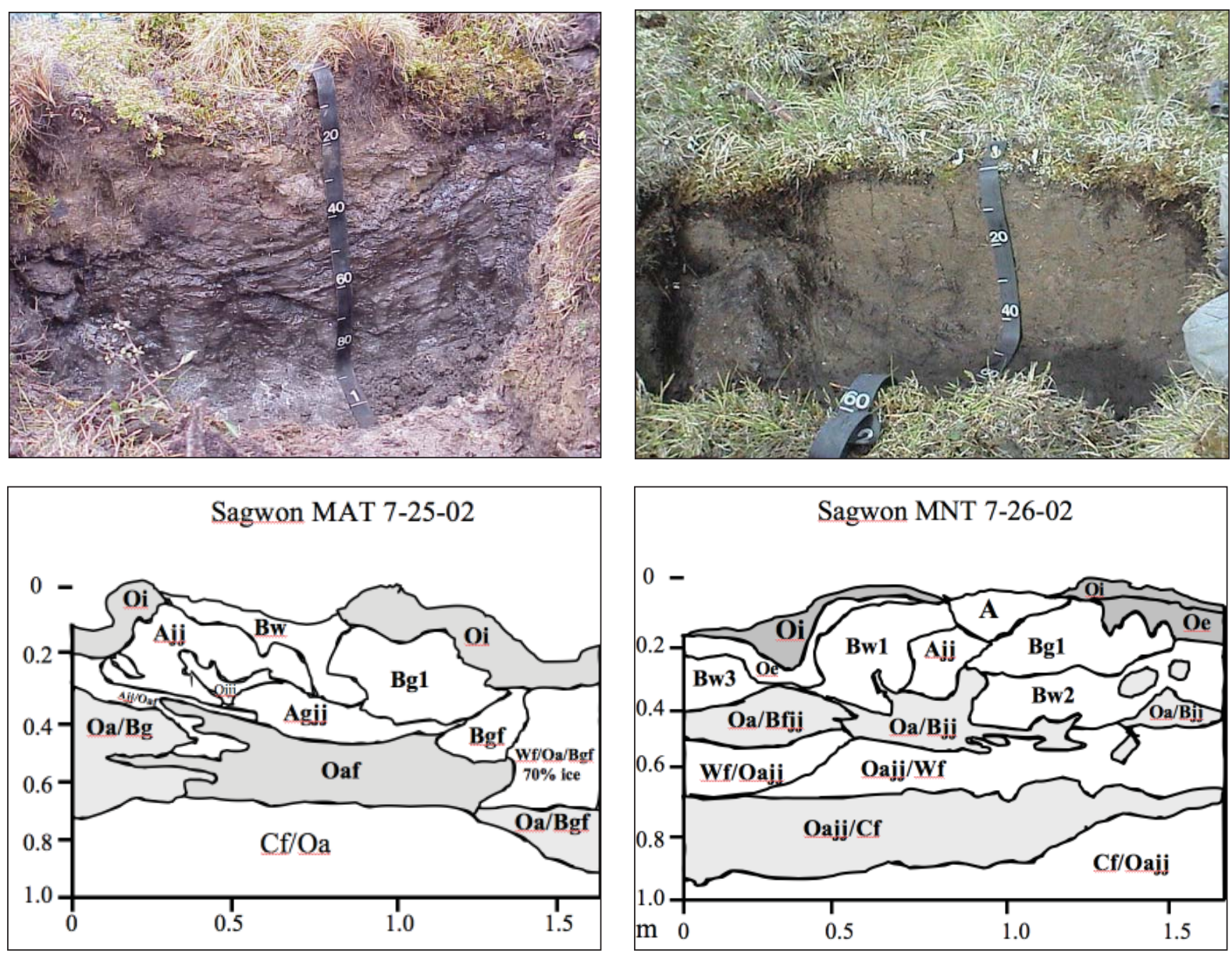

Figure 51. (Top left) Soil associated with Moist Acidic Tundra, Sagwon. (Top right) Soil associated with Moist Nonacidic Tundra. (Bottom) Soil horizon diagrams for Moist Acidic and Nonacidic Tundra. Courtesy of ChienLu Ping and Gary Michaelson.

results are consistent with $\mathrm{CO}_{2}$-flux data from two other ATLAS Flux sites during the same period in 1995. Taken together, the data demonstrate a consistent spatial and temporal pattern of a much larger carbon sink in MAT than in MNT. Methane flux showed a pattern opposite that of $\mathrm{CO}_{2}$, with the wetter, more anaerobic soils of MAT effluxing more than six times the methane of MNT.

Greater carbon accumulation in the vegetation has also led to twice as much organic carbon in both the active layer and the permafrost in the soils at the MAT site compared to the MNT site (table 6). The basal $\mathrm{C}_{14}$ date from the frozen $\mathrm{C}$ horizon at the MAT site was 8,500 $\mathrm{yr}$ BP compared to $12,500 \mathrm{yr} \mathrm{BP}$ in the same horizon at the MNT site, indicating a faster accumulation rate at the acidic site.

Over century to millennium time scales, the zonal soil-pH boundaries may shift northward in response to ongoing climate warming, deeper winter snow packs, and reduction of loess sources. These regions of soil$\mathrm{pH}$ change will show a decrease in soil heat flux and large increases in methane flux and carbon storage in the plant canopy.

\section{Stop 33: Milepost D-386, Franklin Bluffs (photo stop)}

Mile 385.5 Franklin Bluffs

Brown and Kreig, 1983, p. 199

Photo stop to view Franklin Bluffs and examine the braided floodplain of the Sagavanirktok River. The Franklin Bluffs are named for Sir John Franklin, the British explorer who mapped the Arctic coastline and searched for the Northwest passage. Muskox and caribou might be visible along the river and peregrine falcons might be seen in the bluffs (fig. 52).

The flat terrain to the west is part of an old alluvial floodplain of the Sagavanirktok and Putuligayuk rivers. There are relatively few thaw lakes compared to areas farther west and north because thick alluvial gravel deposits are near the surface. Oriented thaw lakes are more abundant in areas with deeper loess or sand deposits. 
Table 5. Comparison of properties of Moist Nonacidic Tundra (MNT) vs. Moist Acidic Tundra (MAT) sites at Sagwon. ${ }^{a}$

MNT

Landscape

Broad ridge top with nonsorted circles $(36 \pm 2 \%$ cover $)$

Soils

Ruptic Histic Aquiturbel, nonacid (69\%) Typic Molliturbel $(23 \%)$, others $(8 \%)$

\section{Vegetation type}

Dryado integrifoliae-Caricetum bigelowii

Walker et al. 1994

Growth forms at top of plant canopy (\% cover)

Nontussock graminoids (36\%), bryoids $(19 \%)$, dwarf $(<50$ $\mathrm{cm})$ deciduous shrubs $(16 \%)$, tussock graminoids $(9 \%)$, lichens $(5 \%)$, forbs and horsetails $(5 \%)$, prostrate deciduous shrubs $(2 \%)$, low $(>50 \mathrm{~cm})$ deciduous shrubs $(2 \%)$, dwarf evergreen shrubs $(1 \%)$

\section{Common vascular plant species} (cover abundance scores)

Arctagrostis latifolia (1), Arctous rubra (1), Astragalus umbellatus (1), Bistorta bistortoides (+), Cardamine hyperborea $(+)$, Carex bigelowii (1), Carex capillaris (+), Carex membranacea $(+)$, Cassiope tetragona $(+)$, Chrysanthemum integrifolium (+), Dryas integrifolia (2), Eriophorum triste (2), Eriophorum vaginatum (1), Juncus biglumis (+), Lupinus arcticus (1), Luzula arctica (+), Minuartia arctica (+), Oxytropis maydelliana $(+)$, Parrya nudicaulis $(+)$, Papaver macounii $(+)$, Pedicularis capitata $(+)$, Pedicularis lanata $(+)$, Polygonum viviparum (+), Pyrola grandiflora (+), Pyrola secunda $(+)$, Rhododendron lapponicum $(+)$, Saussurea angustifolia $(+)$, Saxifraga oppositifolia $(+)$, Salix glauca $(+)$, Salix lanata $(+)$, Salix reticulata $(+)$, Senecio atropurpureus $(+)$, Senecio hieracifolia $(+)$, Senecio resedifolius $(+)$, Silene acaulis $(+)$, Stellaria laeta $(+)$, Tofieldia pusilla $(+)$, Vaccinium uliginosum $(+)$

\section{Common bryophytes}

Dicranum elongatum (1), Distichium capillaceum (1), Ditrichum flexicaule (1), Drepanocladus uncinatus (+), Hylocomium splendens (2), Rhytidium rugosum (2), Thuidium abietinum (+), Tomentypnum nitens (4)

\section{Common lichens}

Cetraria cucullata (+), Cladonia gracilis (+), Cladonia pyxidata $(+)$, Lecanora epibryon $(+)$, Ochrolechia frigida (1), Peltigera aphthosa (+), Peltigera canina (+), Thamnolia subuliformis (1)

\section{MAT}

\section{Landscape}

Broad ridge top, featureless $(1 \pm 1 \%$ cover of nonsorted circles)

\section{Soils}

Typic Aquiturbel (79\%), Typic Histoturbel (21\%)

\section{Vegetation type}

Sphagno-Eriophoretum vaginati

Walker et al. 1994

Growth forms at top of plant canopy (\% cover) Tussock graminoids (25\%), bryoids (19\%), dwarf deciduous shrubs (16\%), dwarf evergreen shrubs (12\%), lichen (8\%), low deciduous shrub (7\%), forbs and horsetails (2\%), nontussock graminoids $(2 \%)$

\section{Common vascular plant species (cover abundance scores)}

Anemone richardsonii (+), Betula nana (2), Bistorta bistortoides (+), Eriophorum vaginatum (3), Carex bigelowii (1), Cassiope tetragona $(+)$, Ledum palustre ssp. decumbens (2), Pedicularis lapponica , Petasites frigidus (+), Poa arctica (+), Pyrola grandiflora (+), Rubus chamaemorus (+), Saxifraga nelsoniana (+), Salix planifolia ssp. pulchra (2), Senecio atropurpureus $(+)$, Vaccinium uliginosum $(+)$, Vaccinium vitis-idaea (1)

\section{Common bryophytes}

Aulacomnium turgidum (1), A. palustre (1), Blepharostoma trichophyllum (+), Dicranum angustum (1), Dicranum spp. (2), Hylocomium splendens (3), Polytrichum strictum (+), Ptilidium ciliare (1), Sphagnum girgensohnii (1), S. lenense (1), S. Sphagnum warnstorfii (1)

\section{Common lichens}

Cetraria cucullata $(+)$, Cetraria islandica $(+)$, Cladina rangiferina $(+)$, Cladonia amaurocraea $(+)$, Cladonia gracilis, Dactylina arctica $(+)$, Peltigera aphthosa (1), Peltigera canina $(+)$, Thamnolia subuliformis $(+)$ 
Table 6. Comparison of ecosystem properties of Moist Nonacidic Tundra (MNT) and Moist Acidic Tundra (MAT) at flux tower sites 3 and 4 and other sites in the Kuparuk River Basin.

\section{Ecosystem Property}

Soil:

$\mathrm{pH}$ of top mineral horizon

O-horizon thickness $(\mathrm{cm})$

Soil moisture of top mineral horizon $\left(\mathrm{cm}^{3}, \mathrm{~cm}^{-3}, \mathrm{Jul} 95\right)$

Bare soil (\% cover)

\section{Vegetation:}

Height of plant canopy $(\mathrm{cm})$

Leaf area index $\left(\mathrm{m}^{2}, \mathrm{~m}^{-2}\right)$

NDVI (MSS)

NDVI (handheld)

Moss cover (\%)

Above-ground biomass $\left(\mathrm{g} \mathrm{m}^{-2}\right)$

Shrubs

Graminoids

Forbs

Mosses, lichens, litter

Total

\section{Energy and trace-gas flux:}

Soil heat flux (19-30 Jun 1995, MJ m ${ }^{-2} \mathrm{~d}^{-1}$ )

Thaw depth $(\mathrm{cm})$

Evapotranspiration (19-30 Jun 1995, $\mathrm{mm} \mathrm{d}^{-1}$ )

10-d gross primary production (19-30 Jun

$1995 \mathrm{~g} \mathrm{CO}_{2}-\mathrm{C} \mathrm{m}^{-2} \mathrm{~d}^{-1}$ )

10-d net $\mathrm{CO} 2$ uptake $\left(\mathrm{g} \mathrm{CO}_{2}-\mathrm{C} \mathrm{m}^{-2} \mathrm{~d}^{-1}\right)$

10-d respiration loss $\left(\mathrm{g} \mathrm{CO}_{2}-\mathrm{C} \mathrm{m}^{-2} \mathrm{~d}^{-1}\right)$

Soil organic carbon $\left(\mathrm{kg} \mathrm{C} \mathrm{m}^{-3}\right)$

\section{MNT}

7.6 [1]

$9 \pm 1$ [71]

0.37 [1]

$4.4 \pm 1.6[6]$

$3.9 \pm 0.3$ [340]

$0.50 \pm 0.03$ [66]

0.23 [1]

$65 \pm 4$ [12]

$85 \pm 18$ [10]

$124 \pm 12$ [10]

$40 \pm 22$ [10]

504

$753 \pm 60[10]$

$1.39 \pm 0.21[331]$
$57 \pm 1[71]$
$1.16 \pm 0.17[331]$

$0.94 \pm 0.14$ [331]

$0.67 \pm 0.10$ [331]

$0.27 \pm 0.04$ [331]

40 [1]
MAT

5.5 [1]

$15 \pm 1$ [71]

$0.40[1]$

$0.2 \pm 0.0$ [6]

\section{$6.5 \pm 0.4$ [340]}

$0.84 \pm 0.05[66]$

0.32 [1]

$79 \pm 4[12]$

$202 \pm 22$ [10]

$112 \pm 15$ [10]

$10 \pm 2$ [10]

460

$784 \pm 139$ [10]

$1.09 \pm 0.16$ [275]

$37 \pm 1$ [71]

$1.06 \pm 0.16$ [275]

***

n.a.

$1.82 \pm 0.27$ [275]

$0.95 \pm 0.14$ [275]

$0.87 \pm 0.13$ [275]

n.a.

n.a.

n.a.

n.a.

Standard error of the mean and number of samples [in brackets] are given for most variables. Probability of significance in all cases were based on two sample t-test. Significance levels: $* \mathrm{p} \leq 0.1 ; * * \mathrm{p} \leq 0.05 ; * * * \mathrm{p} \leq 0.01$; n.s., not significant; n.a., not applicable.

Walker and others, 1998

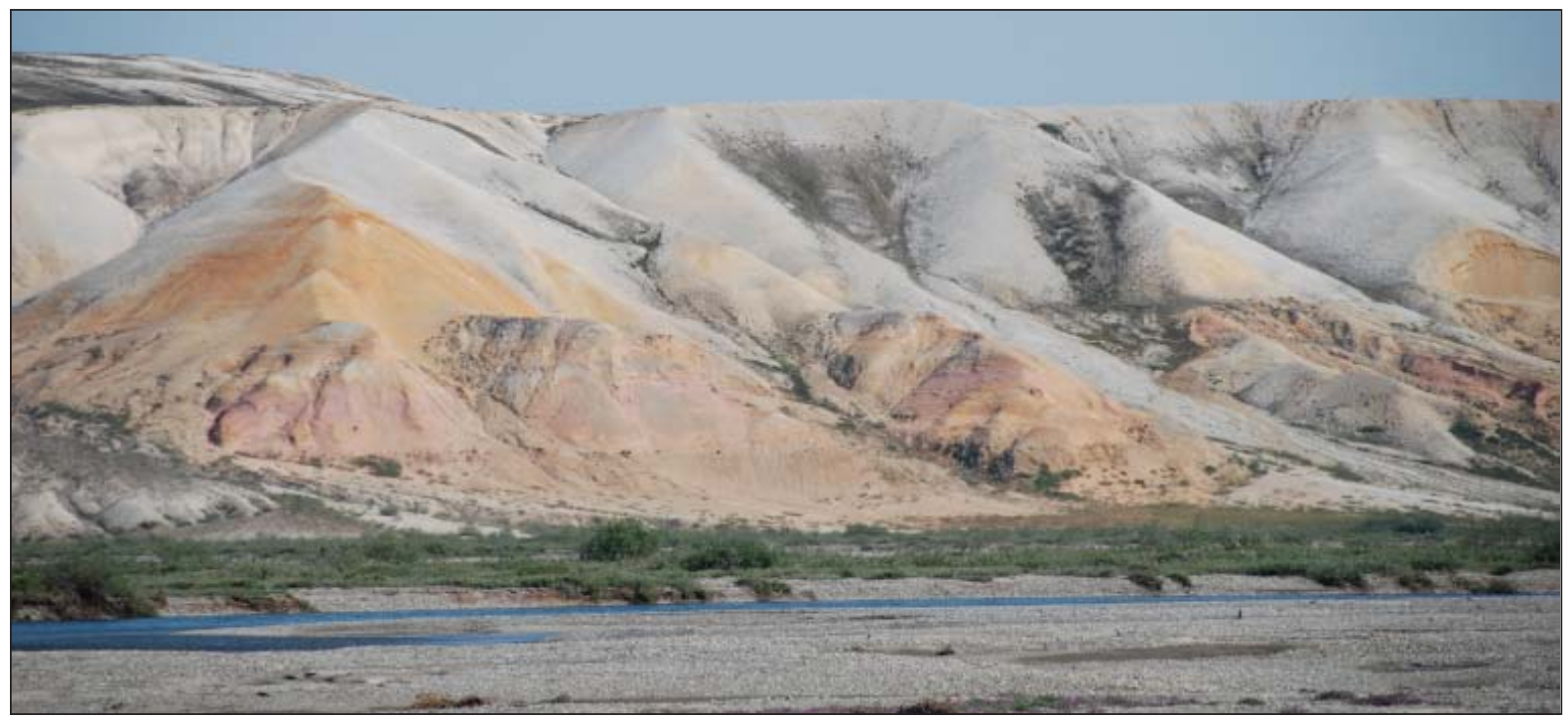

Figure 52. Franklin Bluffs. Photo by D.A. Walker. 
Table 7. Soil profile for Ruptic-Histic Aquiturbel, Moist Acidic Tundra pedon description.

Date sampled: 07/25/2002

Soil series: Sagwon MAT2

Location information: Latitude $69^{\circ} 25.505^{\prime}$ North, Longitude $148^{\circ} 41.714^{\prime}$ West

Slope characteristic information: Slope: 5 percent, Aspect: 350 degrees

Horizontal shape: convex

Vertical shape: convex

Classification: Coarse-loamy, mixed, pergelic, Ruptic-Histic Aquiturbel (Turbic Histic Cryosol)

Vegetative information: Landcover type: moist acidic tundra
Physiography:

Major: Arctic Foothills

Local: Rolling hills

Geomorphic position: side slope

Microtopography: hummocky, frost boils, tussocks

Surface stones: none

Parent material: loess

Runoff: negligible

MAP: $300 \mathrm{~mm}$, est. MAAT: $-5^{\circ} \mathrm{C}$ est. MAST: $-3.3^{\circ} \mathrm{C}$

Type of erosion: none

Degree of erosion: none

\section{Plant names:}

Circle: Ledum decumbens, Racomitrium lanuginosum, Betula nana, Vaccinium vitis-ideae, Cassiope tetragona, Eriophorum vaginatum, Polygonum viviparum, Dactylina arctica, Cetraria cucullata, Cladonia stygia.

Intercircle: Ledum decumbens, Betula nana, Salix arctica, Vaccinium vitis-ideae, Cassiope tetragona, Polygonum bistorta, Eriophorum vaginatum, Hylocomium splendens, Sphagnum sp., Peltigera sp.

Described and sampled by: P. Borden, A. Kade, G. Michaelson, C.L. Ping, C. A. Stiles, and L. Zhu

\section{NONSORTED CIRCLE}

Oi1 0 to $12 \mathrm{~cm}$; very dark gray (10YR 3/1); peat; abrupt broken boundary. $(0-15 \mathrm{~cm})$

Bg1 12 to $35 \mathrm{~cm}$; matrix: dark yellowish brown (10YR 3/4); root channels: dark reddish gray (2.5YR 4/1); fine sandy loam; firm, slightly sticky and plastic; many fine roots; clear wavy boundary. $(0-25 \mathrm{~cm})$

Bg2 35 to $40 \mathrm{~cm}$; oxidized (50\%): yellowish brown (10YR 5/6) and dark brown (10YR 3/3), gleyed (50\%): gray (2.5Y 5/1) and very dark gray (2.5Y 3/1); fine sandy loam; weak medium to coarse blocky structure; firm, slightly sticky and plastic; few fine roots; reacts weakly to $\alpha^{\prime}, \alpha^{\prime}-$ dipyridyl; abrupt broken boundary. (0-20 cm)

A/Bjj 20 to $40 \mathrm{~cm}$; A: $55 \%$; very dark grayish brown (10YR 3/2); B: $45 \%$; yellowish brown (10YR 5/6); sandy loam; friable, slightly sticky and plastic; few fine roots; abrupt broken. $(0-20 \mathrm{~cm})$

Oajj $\quad 40$ to $45 \mathrm{~cm}$; black (7.5YR 2.5/2); muck; weak medium granular structure; very friable; abrupt broken boundary. $(0-10 \mathrm{~cm})$

$\mathrm{Oa} / \mathrm{Bg} 1 \quad 45$ to $62 \mathrm{~cm}$; Oa $(70 \%)$ : very dark brown $(7.5 \mathrm{YR} 3 / 2)$; muck $(66 \%)$ and peaty muck $(34 \%)$; $1 \%$ pebbles, fine to medium woody fragments; Bg1 (30\%): dark gray (2.5Y 4/1); sandy loam; strong fine to medium lenticular structure; $60 \%$ ice; reacts strongly to $\alpha^{\prime}, \alpha^{\prime}$-dipyridyl; abrupt smooth. $(20-30 \mathrm{~cm})$

Oaf $\quad 56$ to $70 \mathrm{~cm}$; very dark gray (10YR 3/2); muck; strong very fine to medium lenticular structure; frozen; abrupt broken boundary. 0-15 cm)

Cf/Oaf $\quad 70$ to $105 \mathrm{~cm}$; Cf (70\%): matrix (90\%): dark gray (2.5Y 5/1) and organic (10\%): brown (7.5YR 4/2); sandy loam; strong medium lenticular structure; $5 \%$ pebbles; $75 \%$ ice; Oaf (30\%): very dark gray (7.5YR 3/1); muck; moderate medium reticular and lenticular; $1 \%$ pebbles; $70 \%$ ice; reacts strongly to $\alpha^{\prime}, \alpha^{\prime}$-dipyridyl; abrupt wavy boundary. $(30-35 \mathrm{~cm})$

2Cf $\quad 105$ to $130 \mathrm{~cm}$; gray (2.5Y 5/1); sandy loam; strong medium reticular structure; slightly sticky and plastic; $10 \%$ organic material: dark brown $(7.5 \mathrm{YR} 3 / 2) ; 5 \%$ pebbles. 
Table 7. Soil profile for Ruptic-Histic Aquiturbel, Moist Acidic Tundra pedon description (continued).

\begin{tabular}{|c|c|}
\hline \multicolumn{2}{|c|}{ INTERCIRCLE } \\
\hline Oi2 & $\begin{array}{l}0 \text { to } 15 \mathrm{~cm} \text {; very dark gray }(7.5 \mathrm{YR} 3 / 2) \text {; peat; few coarse, many medium, fine and very fine } \\
\text { roots; abrupt broken boundary. }(0-15 \mathrm{~cm})\end{array}$ \\
\hline $\mathrm{Oe}$ & $\begin{array}{l}15 \text { to } 28 \mathrm{~cm} \text {; very dark brown }(10 \mathrm{YR} 2 / 2) \text {; peaty muck; common fine and very fine roots; } \\
\text { abrupt broken boundary. }(0-12 \mathrm{~cm})\end{array}$ \\
\hline $\mathrm{Bg} 2$ & $\begin{array}{l}28 \text { to } 35 \mathrm{~cm} \text {; oxidized ( } 50 \%) \text { : yellowish brown }(10 \mathrm{YR} 5 / 6) \text { and dark brown }(10 \mathrm{YR} 3 / 3) \text {, gleyed } \\
(50 \%) \text { : gray }(2.5 \mathrm{Y} 5 / 1) \text { and very dark gray }(2.5 \mathrm{Y} 3 / 1) \text {; fine sandy loam; weak medium to } \\
\text { coarse blocky structure; firm, slightly sticky and plastic; few fine roots; reacts weakly to } \alpha^{\prime}, \alpha^{\prime}- \\
\text { dipyridyl; abrupt broken boundary. }(0-15 \mathrm{~cm})\end{array}$ \\
\hline $\mathrm{Oaf} / \mathrm{Bg} 2 \mathrm{f}$ & $\begin{array}{l}35 \text { to } 60 \mathrm{~cm} \text {; Oaf }(70 \%) \text { : very dark brown }(7.5 \mathrm{YR} 3 / 2) \text {; muck }(66 \%) \text { and peaty muck }(34 \%) \text {; } \\
1 \% \text { pebbles, fine to medium woody fragments; Bg2f }(30 \%) \text { : dark gray }(2.5 \mathrm{Y} 4 / 1) \text {; sandy loam; } \\
\text { strong fine to medium lenticular structure; } 70 \% \text { ice; reacts strongly to } \alpha^{\prime}, \alpha^{\prime} \text {-dipyridyl; abrupt } \\
\text { smooth boundary. }(0-20 \mathrm{~cm})\end{array}$ \\
\hline $\mathrm{Cf} / \mathrm{Oaf}$ & $\begin{array}{l}60 \text { to } 105 \mathrm{~cm} \text {; Cf }(70 \%) \text { : matrix }(90 \%) \text { : dark gray }(2.5 \mathrm{Y} 5 / 1) \text { and organic }(10 \%) \text { : brown } \\
(7.5 \mathrm{YR} 4 / 2) \text {; sandy loam; strong medium lenticular structure; } 5 \% \text { pebbles; } 75 \% \text { ice; Oaf } \\
(30 \%) \text { : very dark gray (7.5YR 3/1); muck; moderate medium reticular and lenticular; } 1 \% \\
\text { pebbles; } 70 \% \text { ice; reacts strongly to } \alpha^{\prime}, \alpha^{\prime} \text {-dipyridyl; abrupt wavy boundary. }(30-35 \mathrm{~cm})\end{array}$ \\
\hline $2 \mathrm{Cf}$ & $\begin{array}{l}105 \text { to } 130 \mathrm{~cm} \text {; gray }(2.5 \mathrm{Y} 5 / 1) \text {; sandy loam; strong medium reticular structure; slightly sticky } \\
\text { and plastic; } 10 \% \text { organic material: dark brown }(7.5 \mathrm{YR} 3 / 2) ; 5 \% \text { pebbles. }\end{array}$ \\
\hline
\end{tabular}

Table 8. Ruptic-Histic Aquiturbel (Turbic Histic Cryosol), Moist Nonacidic pedon description.

Date sampled: 07/26/2002

Soil series: Sagwon MNT3

Location information: Latitude: $69^{\circ} 20^{\prime} 25.0^{\prime \prime} \mathrm{N}$; Longitude: $148^{\circ} 44^{\prime} 58.4^{\prime \prime} \mathrm{E}$

Slope characteristic information: Slope: 7 percent; Aspect: 315 degrees

Horizontal shape: slightly convex

Vertical shape: slightly convex

Classification: Coarse-loamy, mixed, pergelic, Ruptic-Histic Aquiturbel (Turbic Histic Cryosol)

Vegetative information: Landcover type: moist nonacidic tundra
Physiography:

Major: Arctic Foothills

Local: Rolling hills

Geomorphic position: side slope

Microtopography: hummocky, frost boils, tussocks

Surface stones: none

Parent material: loess over glacial till

Runoff: negligible

MAP: $300 \mathrm{~mm}$, est. MAAT: $-5^{\circ} \mathrm{C}$ est. MAST: $-3^{\circ} \mathrm{C}$ est.

Type of erosion: none

Degree of erosion: none

Geomorphic position: side slope

\section{Plant names:}

Circle: Vaccinium vitis-ideae, Cassiope tetragona, Senecio atropurpurescens, Cladonia stygia, Cetraria cucullata, Dryas integrifolia, Tofieldia coccinea, Petasites frigida, Racomitrium lanuginosum, Eriophorum vaginatum, Carex membranaceae, Silene acaulis, Cladonia sp.

Intercircle: Salix reticulata, Vaccinium vitis-ideae, Cassiope tetragonae, Minuartia arctica, Thamnolia subuliformis, Cetraria cucullata, Carex bigelowii, Carex membranaceae, Hylocomium splendens, Peltigera sp., Eriophorum vaginatum, Tomentypnum nitens, Vaccinium uliginosum, Polygonum bistorta.

Described and sampled by: P. Borden, A. Kade, G. Michaelson, C.L. Ping, C.A. Stiles, and L. Zhu 
Table 8. Ruptic-Histic Aquiturbel (Turbic Histic Cryosol), Moist Nonacidic pedon decription (continued).

\begin{tabular}{|c|c|}
\hline \multicolumn{2}{|l|}{ IIRCLE } \\
\hline Oi & $\begin{array}{l}0 \text { to } 2 \mathrm{~cm} \text {; very dark brown }(7.5 \mathrm{YR} 2.5 / 3) \text {; peat; few medium, many fine and very fine roots; } \\
\text { clear wavy boundary. }(0-13 \mathrm{~cm})(1)\end{array}$ \\
\hline Oe & $\begin{array}{l}2 \text { to } 4 \mathrm{~cm} \text {; black ( } 7.5 \text { YR } 2.5 / 1) \text {; mucky peat; common fine and very fine roots; abrupt broken } \\
\text { boundary. }(0-8 \mathrm{~cm})(2)\end{array}$ \\
\hline A & $\begin{array}{l}0 \text { to } 6 \mathrm{~cm} \text {; matrix: dark brown (10YR 3/3) root channel: dark yellowish brown (10YR 4/4); } \\
\text { silt loam; massive (wet); friable, slightly sticky and plastic; common very fine roots; clear } \\
\text { broken boundary. }(0-6 \mathrm{~cm})(4)\end{array}$ \\
\hline Bw1 & $\begin{array}{l}4 \text { to } 25 \mathrm{~cm} \text {; matrix: (90\%) dark grayish brown (10YR 4/2); root channel (10\%) yellowish } \\
\text { brown (10YR 5/6); silt loam; weak medium subangular blocky structure; friable; slightly } \\
\text { sticky and plastic; few medium, many fine and very fine roots; clear broken boundary. (0-25) } \\
\text { (3) }\end{array}$ \\
\hline $\mathrm{Bg} 1$ & $\begin{array}{l}6 \text { to } 27 \mathrm{~cm} \text {; matrix: (96\%) very dark grayish brown (10YR 3/2); mottle oxidized: }(2 \%) \text { dark } \\
\text { yellowish brown (10YR 4/4); mottle reduced: }(2 \%) \text { dark grey }(2.5 \mathrm{Y} 4 / 1) \text {; silt loam; massive } \\
\text { (wet); saturated, slightly sticky, moderately plastic; common medium, many fine and very } \\
\text { fine roots; reacts weakly to } \alpha^{\prime} \alpha \text { '-dipyridyl, clear broken boundary; }(0-25 \mathrm{~cm})(5)\end{array}$ \\
\hline Bw2 & $\begin{array}{l}27 \text { to } 43 \mathrm{~cm} \text {; dark olive brown }(2.5 \text { Y } 3 / 3) \text {; silt loam; strong medium to fine lenticular } \\
\text { structure; slightly sticky, moderately plastic; common medium, many fine and very fine } \\
\text { roots; abrupt broken boundary. }(0-20 \mathrm{~cm})(7)\end{array}$ \\
\hline Ajj & $\begin{array}{l}21 \text { to } 43 \mathrm{~cm} \text {; very dark grayish brown }(2.5 \mathrm{Y} 3 / 2) \text {; silt loam; moderate fine to medium } \\
\text { granular structure; slightly sticky and plastic; few medium, many fine to very fine roots; clear } \\
\text { broken boundary. }(0-25 \mathrm{~cm})(6)\end{array}$ \\
\hline OAfjj & $\begin{array}{l}43 \text { to } 72 \mathrm{~cm} \text {; strong brown }(7.5 \text { YR } 4 / 6) \text {; very dark grayish brown }(10 \mathrm{YR} 3 / 2) \text {; mucky sandy } \\
\text { loam; strong fine lenticular structure; extremely firm; slightly stick and plastic; } 12 \% \text { gravel; } \\
60-70 \% \text { ice; abrupt wavy boundary. }(15-20 \mathrm{~cm})(10)\end{array}$ \\
\hline $\mathrm{Oa} / \mathrm{BCgf}$ & $\begin{array}{l}72 \text { to } 92 \mathrm{~cm} \text {; Oa: dark brown }(7.5 Y R \text { 3/2), muck; BCgf dark grey }(2.5 \mathrm{Y} 4 / 1) \text {; sandy loam; } \\
\text { weak fine lenticular structure; extremely firm; slightly sticky and plastic; reacts strong to } \\
\alpha^{\prime} \alpha^{\prime} \text {-dipyridyl; clear wavy boundary. }(18-25 \mathrm{~cm})(11)\end{array}$ \\
\hline 2Cf/Oafjj & $\begin{array}{l}92 \text { to } 105 \mathrm{~cm} \text {; } 2 \text { CF: very dark grey }(2.5 \mathrm{Y} 3 / 1) \text {; sandy loam; Oafjj: dark grey }(2.5 \mathrm{Y} 4 / 1) \text {; } \\
\text { muck; transition from strong medium to fine lenticular to reticular structure; extremely firm, } \\
\text { slightly sticky and plastic, } 70 \% \text { ice. }\end{array}$ \\
\hline \multicolumn{2}{|c|}{ INTERCIRCLE } \\
\hline Oi & $\begin{array}{l}8 \text { to } 22 \mathrm{~cm} \text {; very dark brown }(7.5 \mathrm{YR} 2.5 / 3) \text {; peat; few medium, many fine and very fine roots; } \\
\text { clear wavy boundary. }(0-15 \mathrm{~cm})(1)\end{array}$ \\
\hline Oe & $\begin{array}{l}22 \text { to } 32 \mathrm{~cm} \text {; black }(7.5 \mathrm{YR} 2.5 / 1) \text {; mucky peat; common fine and very fine roots; abrupt } \\
\text { broken boundary. }(0-12 \mathrm{~cm})(2)\end{array}$ \\
\hline Bw3 & $\begin{array}{l}20 \text { to } 39 \mathrm{~cm} \text {; very dark grayish brown }(10 \mathrm{YR} 3 / 2) \text {; silt loam; weak fine lenticular structure; } \\
\text { saturated, slightly sticky and plastic; few fine and abundant very fine roots; abrupt broken } \\
\text { boundary. }(0-20 \mathrm{~cm})(8)\end{array}$ \\
\hline Oaf/Bgfjj & $\begin{array}{l}\text { 39-50 cm; Oaf: }(80 \%) \text { black (10YR 2/1); mucky; Bgfjj: }(20 \%) \text { very dark grayish brown } \\
(2.5 \mathrm{Y} 3 / 2) \text {; silt loam; strong very fine lenticular structure; extremely firm; slightly sticky and } \\
\text { plastic; abrupt broken boundary. }(0-16 \mathrm{~cm})(9)\end{array}$ \\
\hline Wf/Oa & $39-70 \mathrm{~cm} ;(0-20)(11)$ \\
\hline $\mathrm{Oa} / \mathrm{BCgf}$ & $\begin{array}{l}72 \text { to } 92 \mathrm{~cm} \text {; Oa: dark brown ( } 7.5 \mathrm{YR} 3 / 2) \text {, muck; BCgf: dark grey }(2.5 \mathrm{Y} 4 / 1) \text {; sandy loam; } \\
\text { weak fine lenticular structure; extremely firm; slightly sticky and plastic; reacts strong to } \\
\alpha^{\prime} \alpha^{\prime} \text {-dipyridyl; clear wavy boundary. }\end{array}$ \\
\hline 2Cf/Oafjj & $\begin{array}{l}92 \text { to } 105 \mathrm{~cm} \text {; } 92 \text { to } 105 \mathrm{~cm} \text {; } 2 \mathrm{CF} \text { : very dark grey }(2.5 \mathrm{Y} 3 / 1) \text {; sandy loam; Oafjj: dark grey } \\
(2.5 \mathrm{Y} 4 / 1) \text {; muck; transition from strong medium to fine lenticular to reticular structure; } \\
\text { extremely firm, slightly sticky and plastic, } 70 \% \text { ice. }\end{array}$ \\
\hline
\end{tabular}




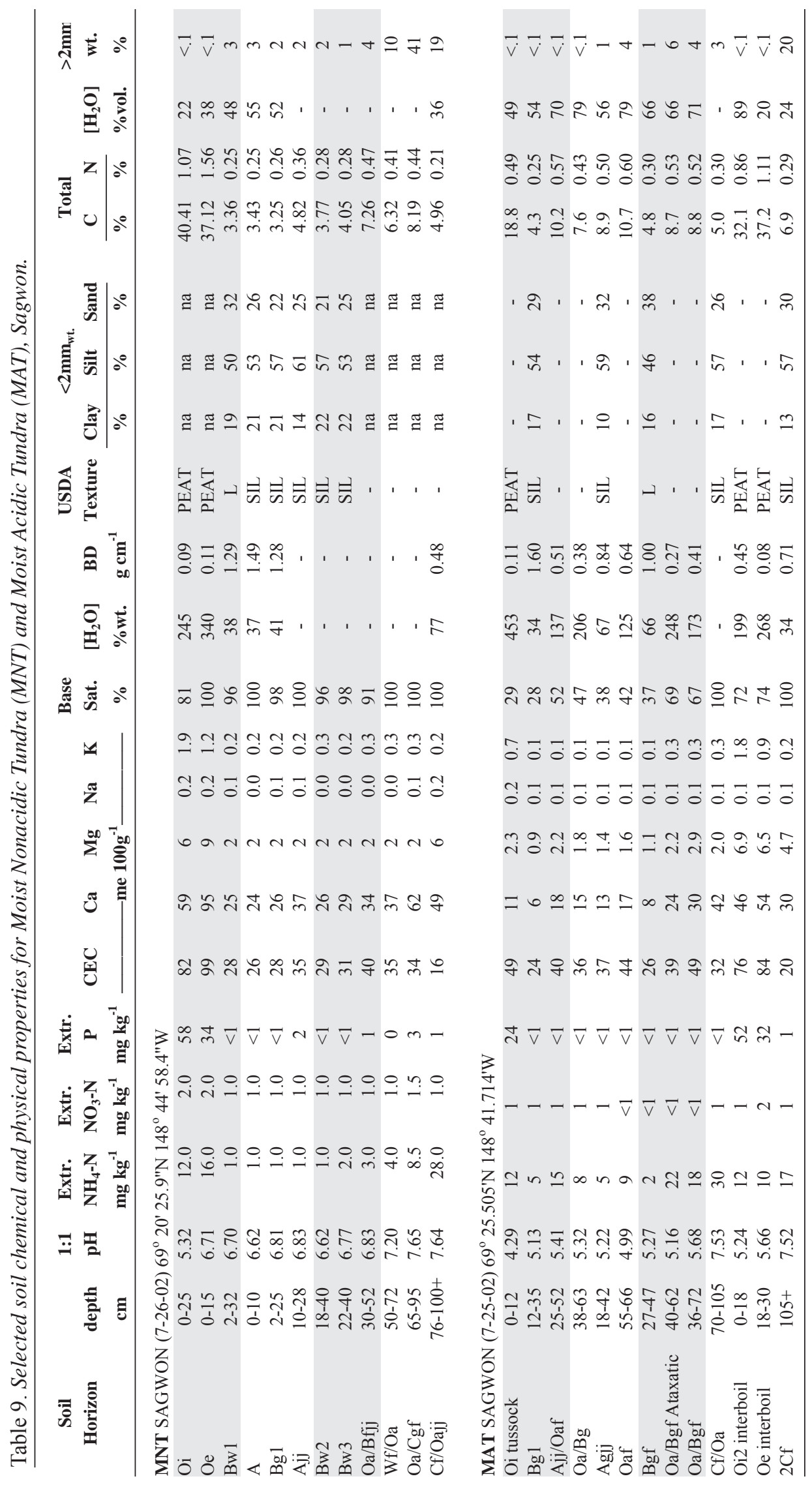


Stop 34: Milepost D-410.8, coastal plain features

As the road approaches the Prudhoe Bay oil field, several stops may be made for various features, including a pingo (fig. 53) and good examples of non-sorted circles in the colder coastal climate.

\section{Stop 35: Milepost D-413.5, eroded low-centered polygons at Deadhorse}

This is a good site to examine the variation in ice-wedge polygons. A large area of thermally eroded ice-wedge polygons is on the east side of the road (fig. 54). These polygons have high centers. Before construction of the road and erosion of the riverbanks by the Sagavanirktok

Figure 53. Percy Pingo.

Photo by D.A. Walker.
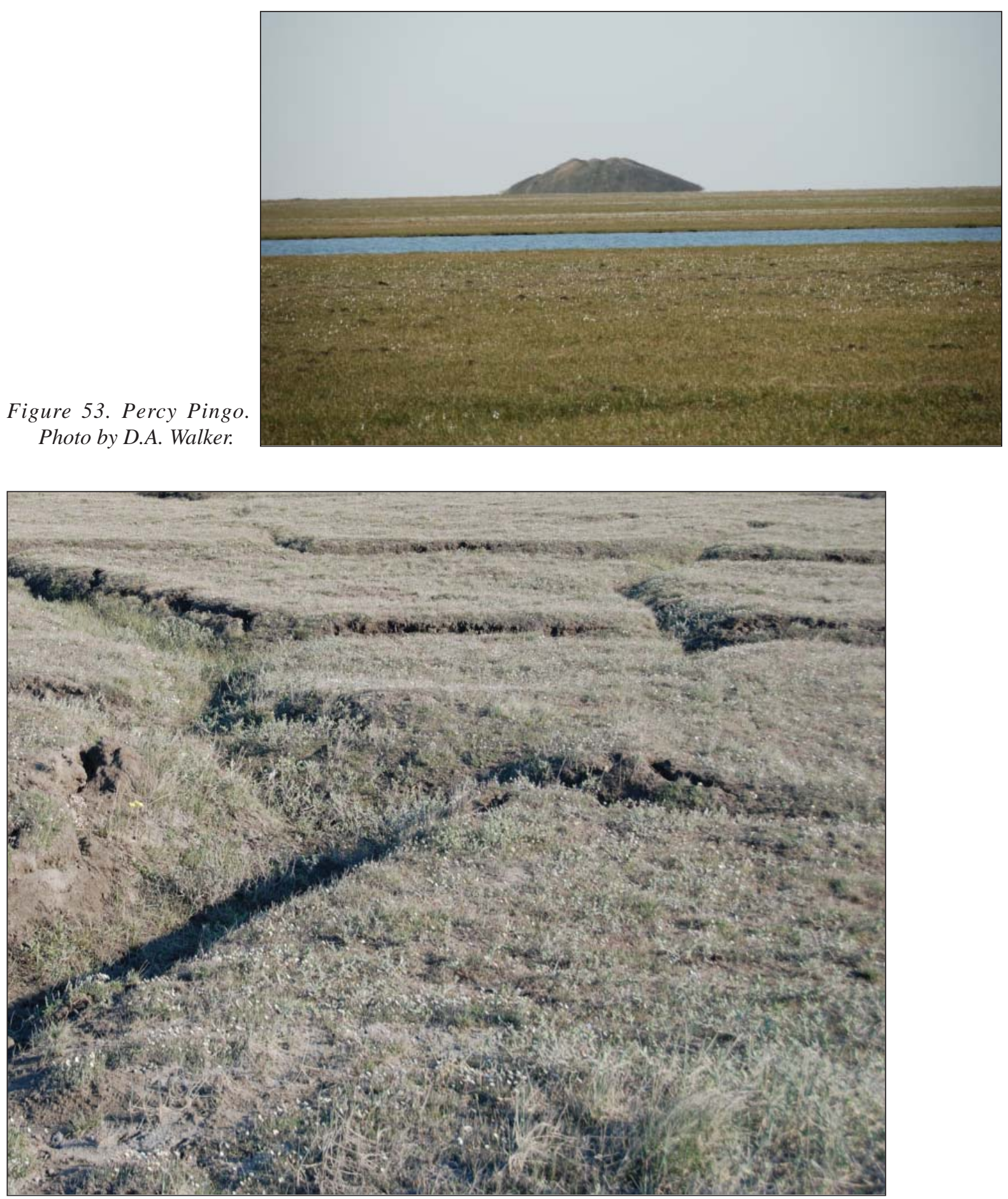

Figure 54. Eroded troughs of low-centered polygons near Deadhorse. Photo by D.A. Walker. 
River, they resembled the low-centered polygons that are on the west side of the road. Near the road, troughs are filled with water and thermal erosion is occurring.

\section{Stop 36: Deadhorse, Arctic Caribou Inn}

The evening will be spent at the Arctic Caribou Inn. An evening presentation by Dr. Bill Streever will provide an introduction to the oil fields in the Prudhoe Bay region.

\section{Day 5}

\section{Prudhoe Bay Oil Field tour}

Overview: On the final day of the field trip, we will receive a tour of Prudhoe Bay Oil Field led by Dr. Bill Streever, BP. The field trip will focus on industry infrastructure, production facilities, engineering, impacts, mitigation, and ecological monitoring. We will visit a pingo, the Arctic Ocean coast, coastal sand dunes, and the delta of the Sagavanirktok River. After the field trip we will fly back to Fairbanks.

En route we will receive a low-elevation overflight of the oil field with photo opportunities of the oilfield facilities, permafrost-related landforms including oriented thaw lakes, braided rivers, beaded ponds, ice-wedge polygons, nonsorted circles, and other patterned-ground features. We will also fly low over the northern portion of the route we covered during the past four days. Appendix D contains the preliminary itinerary for the Prudhoe Bay tour.

\section{REFERENCES CITED}

Auerbach, N.A., and Walker, M.D., 1997, Effects of roadside disturbance on substrate and vegetation properties in Arctic tundra: Ecological Applications, v. 7, no. 1, p. 218-235.

Brown, J., and Berg, R.L., 1980, Environmental engineering and ecological baseline investigations along the Yukon River-Prudhoe Bay Haul Road: Hanover, NH, U.S. Army Cold Regions Research \& Engineering Laboratory (CRREL) Report 80-19, 190 p.

Brown, Jerry, and Kreig, R.A., eds., 1983, Guidebook to permafrost and related features along the Elliott and Dalton Highways, Fox to Prudhoe Bay, Alaska: Alaska Division of Geological \& Geophysical Surveys Guidebook 4, 230 p.

Chapin, F.S., III, Shaver, G.R., Giblin, A.E., Nadelhoffer, K.J., and Laundre, J.A., 1995, Responses of arctic tundra to experimental and observed changes in climate: Ecology v. 76, p. 694-711.

CAVM Team (Walker, D.A. [project director], Bliss, L.C., Edlund, S.A., Raynolds, M.K., Zoltai, S.C., Daniëls, F.J.A., Bay, C., Wilhelm, M., Einarsson,
E., Gudjonsson, G., Elvebakk, A., Johansen, B.E., Ananjeva, G.V., Drozdov, D.S., Katenin, A.E., Kholod, S.S., Konchenko, L.A., Korostelev, Y.V., Melnikov, E.S., Moskalenko, N.G., Polezhaev, A.N., Ponomareva, O.E., Pospelova, E.B., Safronova, I.N., Shelkunova, R.P., Yurtsev, B.A., Fleming, M.D., Markon, C.J., Murray, D.F., and Talbot, S.S.), 2003, Circumpolar Arctic Vegetation Map, in Conservation of Arctic Flora and Fauna (CAFF) Map No. 1: Anchorage, AK, U.S. Fish and Wildlife Service, 1 sheet, scale 1:7,500,000.

Daanen, R.P., Misra, D., and Epstein, H.E., 2007, Active-layer hydrology in non-sorted circle ecosystems of the Arctic tundra: Vadose Zone Journal, v. 6, p. 694-704.

Detterman, R.L., Bowsher, A.L., and Dutro, J.T., Jr, 1958, Glaciation on the arctic slope of the Brooks Range, northern Alaska: Arctic, v. 11, p. 43-61.

Diel, W.R., and Banet, A.C., Jr., 1993, Riches from the earth; A geologic tour along the Dalton Highway: Alaska Natural History Association in cooperation with BLM Alaska. Please call 907-271-5968 or 9072715970 for hard copy availability.

Doak, P., Wagner, D., and Watson, A., 2007, Variable extrafloral nectary expression and its consequences in quaking aspen: Canadian Journal of Botany, v. 85, p. 1-9.

Ellis, J.M., and Calkin, P.E., 1979, Nature and distribution of glaciers, neoglacial moraines, and rock glaciers, east-central Brooks Range, Alaska: Arctic and Alpine Research, v. 11, p. 403-420.

Everett, K.R., 1979, Distribution and properties of road dust generated from the Yukon River-Prudhoe Bay Haul Road north of the Brooks Range: Hanover, NH, U.S. Army Cold Regions Research \& Engineering Laboratory (CRREL) annual report, 24 p.

Gough, L., Shaver, G.R., Carroll, J., Royer, D.L., and Laundre, J.A., 2000, Vascular plant species richness in Alaskan arctic tundra; The importance of soil $\mathrm{pH}$ : Journal of Ecology, v. 88, p. 54-66.

Hamilton, T.D., 1986, Late Cenozoic glaciation of the Central Brooks Range,in Hamilton, T.D., Reed, K.M., and Thorson, R.M., eds. Glaciation in Alaska: the Geologic Record: Anchorage, Alaska, Alaska Geological Society, p. 9-49.

Hamilton, T.D., ed., 2003, Glacial Geology of Toolik Lake and the Upper Kuparuk River Region: Fairbanks, Alaska, University of Alaska Press, 24 p.

Hamilton, T.D., 2003, Surficial geology of the Dalton Highway (Itkillik-Sagavanirktok rivers) area, southern Arctic foothills, Alaska: Alaska Division of Geological \& Geophysical Surveys Professional Report 121, 32 p., 1 sheet, scale 1:63,360. 
Haugen, R.K., 1982, Climate of remote areas in northcentral Alaska, 1975-1979: Hanover, NH, U.S. Army Cold Regions Research \& Engineering Laboratory (CRREL) Report 82-35, 110 p.

$\mathrm{Hu}$, X., and Pollard, W., 1997, The hydrologic analysis and modeling of river icing growth, North Fork Pass, Yukon Territory, Canada: Permafrost and Periglacial Processes, v. 8, p. 279-294.

Jia, G.J., Epstein, H.E., and Walker, D.A., 2003, Greening of arctic Alaska, 1981-2001: Geophysical Research Letters v. 30, p. HLS-1-4, doi:10,1029/ 2003GL18268

Jorgenson, M.T., 1986, Controls of the geographic variability of soil heat flux near Toolik Lake, Alaska: Fairbanks, Alaska, University of Alaska Fairbanks, M.S. Thesis, 109 p.

Kade, A. and Walker, D.A., 2008, Experimental alteration of vegetation on nonsorted circles; Effects on cryogenic activity and implications for climate change in the Arctic: Arctic, Antarctic and Alpine Research, v. 40, p. 96-103.

Kane, D.L., Hinzman, L.D., McNamara, J.P., Zhang, Z., and Benson, C.S., 2000, An Overview of a Nested Watershed Study in Arctic Alaska. Nordic Hydrology, 4/5:245-266.

Kane, D.L., Hinzman, L.D., Gieck, R.E., McNamara, J.P., Youcha, E., and Oatley, J.A., 2008, Contrasting Extreme Runoff Events in Areas of Continuous Permafrost, Arctic Alaska: Hydrology Research, 38, no. 4, p. 287-298.

Mack, M.C., Schurr, E.A.G., Bret-Harte, M.S., Shaver, G.R., and Chapin, F.S., III, 2004, Ecosystem carbon storage in arctic tundra reduced by long-term nutrient fertilization: Nature, v. 431, p. 440-443.

Myneni, R.B., Tucker, C.J., Asrar, G., and Keeling, C.D., 1998, Interannual variations in satellite-sensed vegetation index data from 1981 to 1991: Journal of Geophysical Research, v. 103, p. 6,145-6,160.

Nelson, F.E., Shiklomanov, N.I., Mueller, G.R., Hinkel, K.M., Walker, D.A., and Bockheim, J.G., 1997, Estimating active-layer thickness over a large region; Kuparuk River Basin, Alaska: Arctic, Antarctic, and Alpine Research, v. 29, p. 367-378.

Nicolsky, D.J., Tipenko, G.S., Romanovsky, V.E., and Walker, D.A., 2008, Modeling biogeophysical interactions in non-sorted circles in the Low Arctic: Journal of Geophysical Research - Biogeosciences, 113, GOSO5.doi:10.1029/2007JG000565.

Oechel, W.C., Vourlitis, G.L., Brooks, S., Crawford, T.L., and Dumas, E., 1998, Intercomparison among chamber, tower, and aircraft net $\mathrm{CO}_{2}$ and energy fluxes measured during the Arctic System Science/ Land-Atmosphere-Ice Interactions (ARCSS/LAII)
Flux Study: Journal of Geophysical Research, v. 103, p. $28,993-29,004$.

Osterkamp, T.E. 2003, A thermal history of permafrost in Alaska, in Phillips, M., Springman, S.M., and Arenson, L.U., eds., Permafrost; Proceedings of the Eighth International Conference on Permafrost: Zurich, Switzerland, A.A. Balkema Publishers, p. 863-868.

Osterkamp, T.E., and Romanovsky, V.E., 1999, Evidence for warming and thawing of discontinuous permafrost in Alaska: Permafrost and Periglacial Processes, v. 10 , p. 17-37.

Oswald, W.W., Brubaker, L.B., Hu, F.S., and Kling, G.W., 2003, Holocene pollen records from the central Arctic Foothills, northern Alaska; Testing the role of substrate in the response to climate change: Journal of Ecology, v. 91, p. 1,034-1,048.

Peterson, R.A., and Krantz, W.B., 2008, Differential frost heave model of patterned ground formation; Corroboration with observations along a North American Arctic Transect: Journal of Geophysical Research - Biogeosciences, 113, GOSO4. doi:10.1029/2007JG000559.

Pielou, E.C., 1994, A naturalist's guide to the Arctic: Chicago, IL, The University of Chicago Press, $327 \mathrm{p}$.

Ping, C.L., Michaelson, G.J., Kimble, J.M., Romanovsky, V.E., Shur, Y.L., Swanson, D.K., and Walker, D.A., 2008, Cryogenesis and soil formation along a bioclimate gradient in Arctic North America: Journal of Geophysical Research - Biogeosciences, 113, GOS12.doi:10.1029/2007JG000774.

Razzhivin, V.Y., 1999, Zonation of vegetation in the Russian Arctic, in Nordal, I., and Razzhivin, V.Y., eds., The species concept in the high north-A panarctic flora initiative: Oslo, Norway, The Norwegian Academy of Science and Letters, p. 113-130.

Reynolds, J.F., and Tenhunen, J.D., eds., 1996, Landscape function and disturbance in Arctic tundra: New York, Springer-Verlag, 437 p.

Romanovsky, V.E., and Osterkamp, T.E., 2001, Permafrost monitoring system in Alaska; Structure and results (in Russian): Earth Cryosphere v. 5, p. 59-68.

Romanovsky, V.E., Sergueev, D.O., and Osterkamp, T.E., 2003, Temporal variations in the active layer and new-surface permafrost temperatures at the long-term observatories in northern Alaska, in Phillips, M., Springman, S.M., and Arenson, L.U., eds., Permafrost; Proceedings of the Eighth International Conference on Permafrost: Zurich, Switzerland, A.A. Balkema Publishers, p. 989-994.

Rozell, Ned, 2005, Aspen miners leave few leaves unturned: Fairbanks, Alaska, Geophysical Institute, University of Alaska Fairbanks, Alaska Science Forum, June 2, 2005, Article 1753. 
Shaver, G.R., Bret-Harte, M.S., Jones, M.H., Johnstone, J., Gough, L., Laundre, J., and Chapin, F.S., III, 2001, Species composition interacts with fertilizer to control long-term change in tundra productivity: Ecology, v. 82, p. 3,163-3,181.

Tape, K., Sturm, M.J., and Racine, C.J., 2006, The evidence for shrub expansion in northern Alaska and the Pan Arctic: Global Change Biology, v. 12, p. 686-702.

Walker, D.A, 1985, The vegetation and environmental gradients of the Prudhoe Bay Region, Alaska: Hanover, NH, U.S. Army Cold Regions Research and Engineering Laboratory (CRREL), 239 p.

Walker, D.A., and Everett, K.R., 1987, Road dust and its environmental impact on Alaskan taiga and tundra: Arctic and Alpine Research, v. 19, no. 4, p. 479-489.

Walker, D.A. and Walker, M.D., 1996, Terrain and vegetation of the Imnavait Creek watershed, in Reynolds, J.F., and Tenhunen, J.D., eds., Landscape function; Implications for ecosystem disturbance, a case study in Arctic tundra: New York, SpringerVerlag, p. 73-108.

Walker, D.A., Auerbach, N.A., Bockheim, J.G., Chapin, F.S.I., Eugster, W., King, J.Y., McFadden, J.P., Michaelson, G.J., Nelson, F.E., Oechel, W.C., Ping, C.L., Reeburg, W.S., Regli, S., Shiklomanov, N.I., and Vourlitis, G.L., 1998, Energy and trace-gas fluxes across a soil pH boundary in the Arctic: Nature, v. 394, p. 469-472.

Walker, D.A., Epstein, H.E., Romanovsky, V.E., Ping, C.L., Michaelson, G.J., Daanen, R.P., Shur, Y., Peterson, R.A., Krantz, W.B., Raynolds, M.K., Gould, W.A., Gonzalez, G., Nickolsky, D.J., Vonlanthen, C.M., Kade, A.N., Kuss, P., Kelley, A.M., Munger,
C.A., Tarnocai, C.T., Matveyeva, N.V., and Daniëls, F.J.A., 2008, Arctic patterned-ground ecosystems; a synthesis of field studies and models along a North American Arctic Transect: Journal of Geophysical Research - Biogeosciences, 113, GOSO1. doi:10.1029/2007JG000504.

Walker, M.D., Walker, D.A., and Everett, K.R., 1989, Wetland soils and vegetation, Arctic Foothills, Alaska: U.S. Fish and Wildlife Service Biological Report 89 (7), 102 p.

Weller, G., Chapin, F.S., Everett, K.R., Hobbie, J.E., Kane, D., Oechel, W.C., Ping, C.L., Reeburgh, W.S., Walker, D., and Walsh, J., 1995, The Arctic Flux Study; A regional view of trace gas release: Journal of Biogeography, v. 22, p. 365-374.

Werbe, E., 1980, Disturbance effects of a gravel highway upon Alaskan tundra vegetation: Boulder, CO, University of Colorado, Boulder, M.A. thesis, 153 p.

Wilmking, Martin, and Ibendorf, Jens, 2004, An early tree-line experiment by a wilderness advocate; Bob Marshall's legacy in the Brooks Range, Alaska: Arctic, v. 57, no. 1, p. 106-113.

Yoshikawa, K., Hinzman, L.D., and Kane, D.L., 2007, Spring and aufeis (icing) hydrology in the Brooks Range, Alaska: Journal of Geophysical Research, v. 112: G04S43, doi:10.1029/2006JG000294, http:// www.agu.org/pubs/crossref/2007/2006JG000294. shtml

Zhou, L., Tucker, C.J., Kaufmann, R.K., Slayback, D., Shabanov, N.V., and Myneni, R.B., 2001, Variations in northern vegetation activity inferred from satellite data of vegetation index during 1981 to1999: Journal of Geophysical Research - Atmospheres, v. 106, p. 20,069-20,083. 


\title{
APPENDIX A \\ The Essentials of Alaskan Geology and Geomorphology Bedrock and Glacial Geology of Tour Route
}

\author{
C.A. Stiles, Soil Scientist, NSSL-NRCS USDA, Lincoln, NE \\ T. Hamilton, Geologist USGS (retired), Anchorage, AK
}

\section{Introduction}

Under the thick tundra mats and taiga forests along the road north from Fairbanks lies the complicated skeleton of Alaska, a bedrock patchwork quilt that is just as fascinating to look at as the wildlife (and more reliably present). Along this route, we will cross seven physiographic provinces oriented in east-west trends that are roughly equivalent to several provinces that span the greater part of continental North America (figs. A-1a and 1b). We will traverse lands that have been heavily scoured by Quaternary glaciations and those untouched by the direct effects of glaciers, but still carrying evidence of the periglacial legacy. Our trip takes us through two major river drainages (Yukon and Koyukuk), across the Brooks Range-the northernmost range in the Rocky Mountain chain—and finally down onto the Arctic coastal plain, where portions are used for oil exploration and others for subsistence lifestyles in the great "Serengeti of North America." Here lies something for every earth watcher to enjoy. For the rockhound, the most spectacular vistas are the stark outcrops of the Brooks Range, where vegetation scarcely covers the lower elevation toeslopes because of the high latitude location. Glacial aficionados will appreciate the deeply incised U-shaped valleys and morainal topography of the Brooks Range foothills that reflect the direct influence of valley glaciers during the last several million years. Finally, the subtle permafrost-dominated topography of the Arctic coastal plain displays rare landforms not found anywhere else in the USA. The following is a brief review of geology and geomorphology concepts as they apply to this field trip. Much of the material describing the structure and stratigraphy has been summarized from Mull (1989).

\section{Terranes}

Alaska is located at the very end of the spine of the two American continents. The spine of mountains that follows the general alignment of North and South America runs from its southernmost point in Tierra del Fuego as the Andes Mountains up through Central America as the Cordillera Central and then through North America as the Rocky Mountain chain. The Brooks Range is the northernmost expression of this spine and its east-west trend has forced the accretion of no less than 26 fault-bounded sub-continental size chunks or terranes of differing stratigraphy and age that have accumulated along continental suture zones.

Fairbanks and its surrounding mining areas are located on the Proterozoic age (2,500-600 Ma) Yukon-Tanana terrane containing the Birch Creek Schist and associated gold-bearing members. We traverse several terranes and subterranes on the trip north to Deadhorse, especially as we cross the Brooks Range. The major terranes are, from south to north: the Wickersham, Manley, White Mountain, Tozitna, Ruby, and Angayucham terranes, the Coldfoot, Hammond, and Endicott Mountains subterranes, and finally the Arctic-Alaska terrane. Each is characterized by different stacked, and sometimes disordered and overprinted, layers of rocks that were initially laid down by the earth-building process at the time and place of their formation. The age of the terranes varies within the units, but by and large, they get younger as we head north out of the Yukon-Tanana River basin. The southern face of the Brooks Range tends to have a more accretionary architecture, which simply means that the time sequence isn't always very easy to follow. However, once over Atigun Pass and onto the North Slope, the time series of rocks is easy to follow, progressing from Devonian (410 Ma) to undifferentiated Paleogene (65-23 Ma) sediments overlain by a thickening-to-the-north veneer of Quaternary alluvial and glacial sediments.

\section{Formation sequences and their rocks}

The passage through different terranes does not mean that we pass simply from one rock type to another, although in some cases such as the Angayucham terrane, the geochemical composition of the rock is different from the country rock because of its origin in deep oceanic spreading zones. In each physiographic/terrane province we pass through, you will notice predominance of some particular rock types related to past depositional settings and tectonic activities.

Sequences are time-transgressive depositional entities that give a strong indication of local geological conditions that prevailed during the time the rocks were deposited. There are three major sequences that each encompass several formations as we move from south to north along the highway from Fairbanks to Deadhorse. These sequences 
present a picture of the evolution of this portion of North America through the rock types and morphologies in the formations, from the early accretion of sediments onto the ancient proto-continental Canadian Shield far to the east, to the most recent shedding of colluvium off the uplifted Brooks Range and development of the hydrocarbonenriched Arctic Slope/Colville basin.

The southernmost sequence is the Franklinian Sequence, which comprises Proterozoic to mid-Devonian strata of argillites, limestone/dolostone, volcanic rocks, phyllites, and shales. This sequence represents early mountainbuilding events that initiated in western Canada and built out the core of the Alaskan "thumb" that allowed for later terrane accretion. In the southern Brooks Range, the Franklinian Sequence is often metamorphosed to upper greenschist to amphibolite facies, meaning the rocks are schists and gneiss (often banded with graphite), marble, and felsic intrusive rocks. The most spectacular expression of the Franklinian Sequence is the Skajit Limestone that makes up the massive cliffs encountered along the Dalton Highway from miles 203 through 224, starting with the monumental Sukakpak Mountain, the marker of the Gates of the Arctic National Park and the Arctic National Wildlife Refuge.
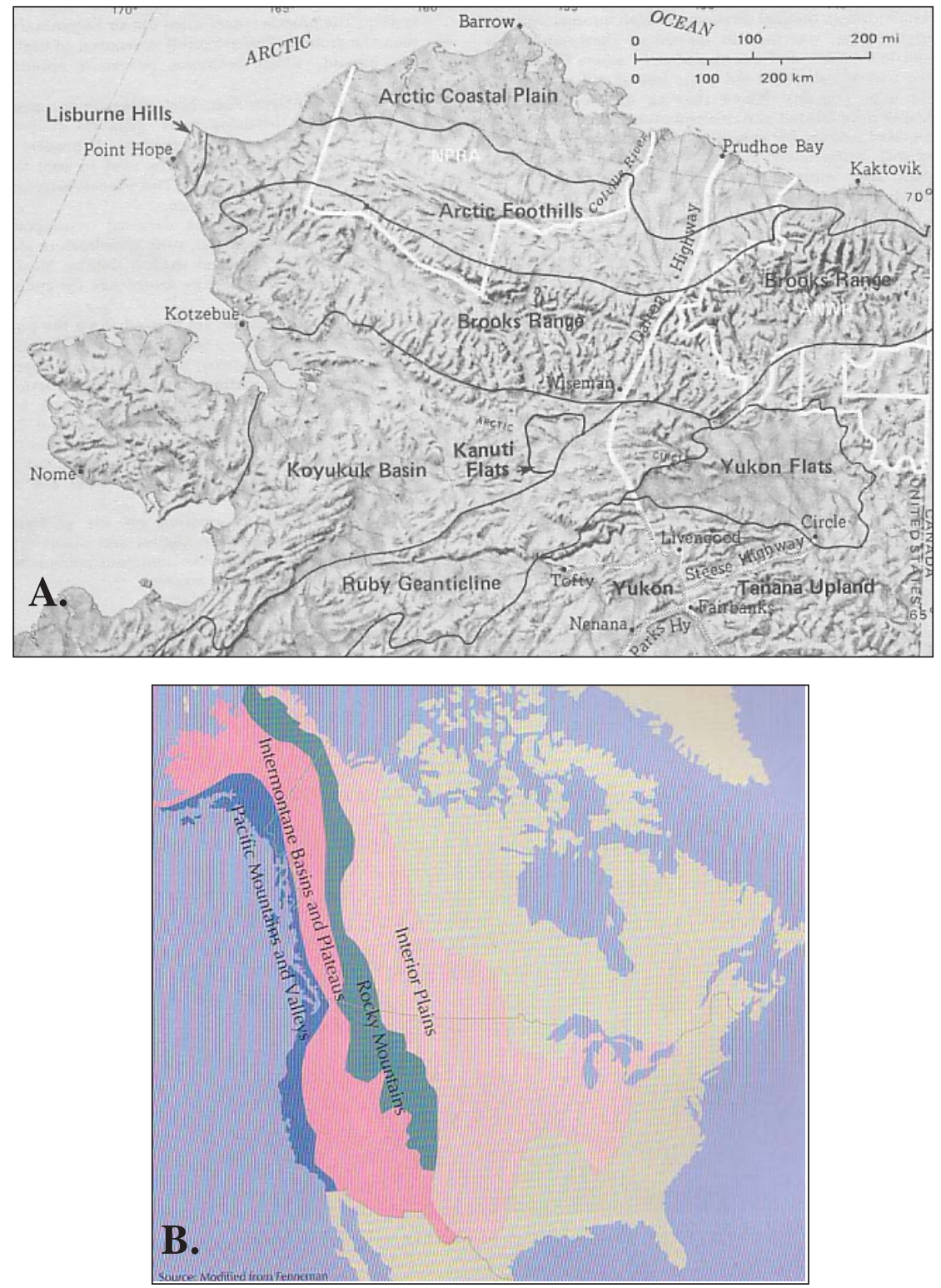

Figure A-1. (A) Physiographic provinces of northern Alaska (Mull and Adams, 1989); (B) Physiographic regions of western North America (Pearson and Hermans, 2003). 
The next chronostratigraphic sequence is the Ellesmerian Sequence that ranges in age roughly from late Devonian to early Cretaceous (fig. A-2). These rocks are derived from sediments again from a northern source but deposited on a stable platform during a time of relative quiet with only three major sea level changes. They are primarily shales, conglomerates, and sandstones, with one prominent limestone formation, the Lisburne Formation, a significant ridge former in this relatively dry climate. On the south face of the Brooks Range, the Ellesmerian rocks are metamorphosed and comprise the foreboding dark rocks of Atigun Pass. Rocks from this sequence extend from mileposts 224 through 271, ending near Galbraith Lake and bounded by the Atigun River Valley, where an extensive unconformity occurs.

The dramatic Atigun River Valley, trending east-west from the Dalton Highway at Milepost 271, is where the final and youngest sequence commences. The Brookian Sequence represents a time interval from the Cretaceous to an unspecified time within the early to mid Tertiary. The end outcrop of the Ellesmerian Sequence along the Dalton Highway is the high rampart of Mt. Hultèn, with its spectacular $600 \mathrm{~m}$ (1,970 ft) rise above the deep Ushaped valleys in which the highway runs. This mountain is part of an overturned sequence that was emplaced by extensive thrust faulting when the Brooks Range was forced upward. Brittle failure of the carbonate-rich Lisburne created the deep valley through which the Atigun River was directed. Evidence of this folding is found at the toeslope of the mountain between milemarkers 270 and 271.

Brookian Sequence rocks are less metamorphosed and represent the sediments shed from the south to the north during the Brooks Range uplift, an abrupt shift from the underlying sequences. The rocks here are shales, sandstones, and conglomerates (fig. A-3). There are very few calcareous rocks in this sequence, as most of the strata represent shedding off of pre-existing siliciclastic material from the south. Coals and fossils at the surface attest to the lack of metamorphosis and also hint at subterranean hydrocarbon occurrences that are found in the Colville Basin and the Arctic Ocean coastline. The most significant feature in the Brookian Sequence is the relatively regular stratigraphy, the silicate-dominated mineralogy, and the K-T boundary. This occurs between mile markers 352 and 354, underlying the Sagwon bluffs near the Sagavanirktok River, where the upper Cretaceous Prince Creek Formation underlies the lower

Figure A-3. Generalized stratigraphic relationships in the Brookian sequence of the Colville Basin on the North Slope. Note: Kingak Shale, Kemik Sandstone, and Pebble Shale are Ellesmerian members (Mull and Adams, 1989).

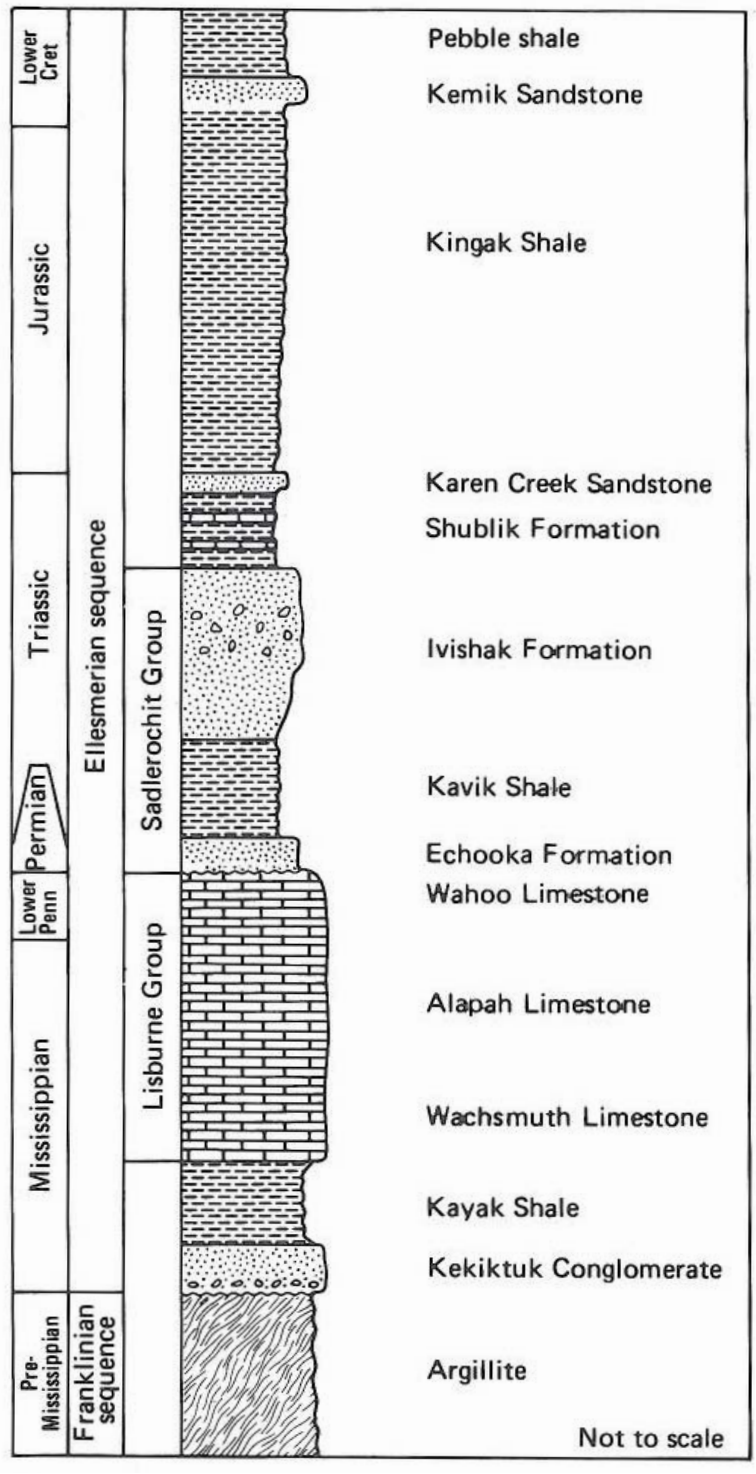

Figure A-2. Generalized stratigraphic column showing upper Franklinian and complete Ellesmerian sequence in the northeastern Brooks Range (Mull and Adams, 1989).

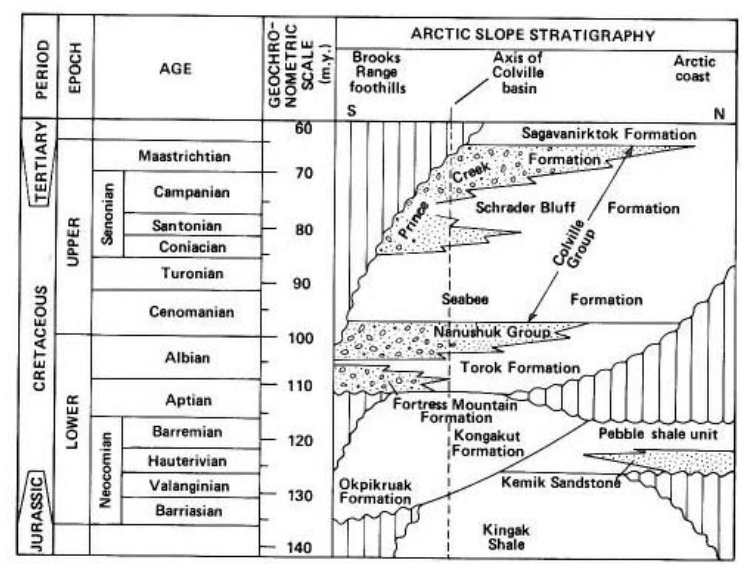


Paleogene Sagavanirktok Formation. The badlands-like Franklin Bluffs between mile markers 381 and 395 are the last surficial exposure of lithified sediments and may represent yet another significant paleoclimatic boundary, the Initial Eocene Thermal Maximum. This interval is notable in that crocodilians and sub-tropical flora occurred in this part of the world, despite the continents being in pretty much the same locations they are today. Think of it, crocodiles in Alaska, and not in some hothouse or zoo! It is hard to believe with all this permafrost underfoot.

\section{Soil formation}

Now that the sequences have been set out, what does that mean for soils and plants? Probably one of the most notable features about these rock formations is the balance of silicates and carbonates between the eastern and western North Slope of the Brooks Range.

To the west, the rocks are primarily siliceous and material derived from those rocks is rich in silicon (Si), aluminum (Al), and iron (Fe). The carbonaceous rocks to the east of the Alaska Pipeline extend closer to the Arctic coast and are enriched in alkaline earth elements (calcium [Ca], magnesium [Mg], sodium [Na], and potassium $[\mathrm{K}]$ ) as well as having some isolated outcrops of rock formations bearing phosphorus (P). This makes a difference in the native fertility of the soil, although cryoturbation processes often dominate soil formation.

\section{Glacial processes and characteristic mor- phologies}

Glaciers have played an important role in shaping the Brooks Range. These mountain glaciers were confined to deep valleys, and flowed out as tongues or lobes southward into the Alaskan Interior and northward onto the Arctic coastal plain (fig. A-4). Glacial advances occurred from the late Tertiary until as recently as 12,000 yr BP in the major valleys and during the last several thousand years within cirques along the Continental Divide.

The drift deposits in foothills north and south of the Brooks Range become progressively younger approaching the flanks of the range, as elevation increases. The oldest deposits on the north side, termed Gunsight Mountain, consist only of erratic boulders of the highly resistant Kanayut Conglomerate. These boulders usually are restricted to terraces and piedmont zones that stand high above modern drainages. Any morainal features associated with these erratics have been obliterated during the long interval of weathering and erosion that followed their deposition. The Anaktuvuk River drift contains broad and subdued but still recognizable morainal landforms. It also tends to occur on abandoned surfaces that stand above modern valley floors. Glacial

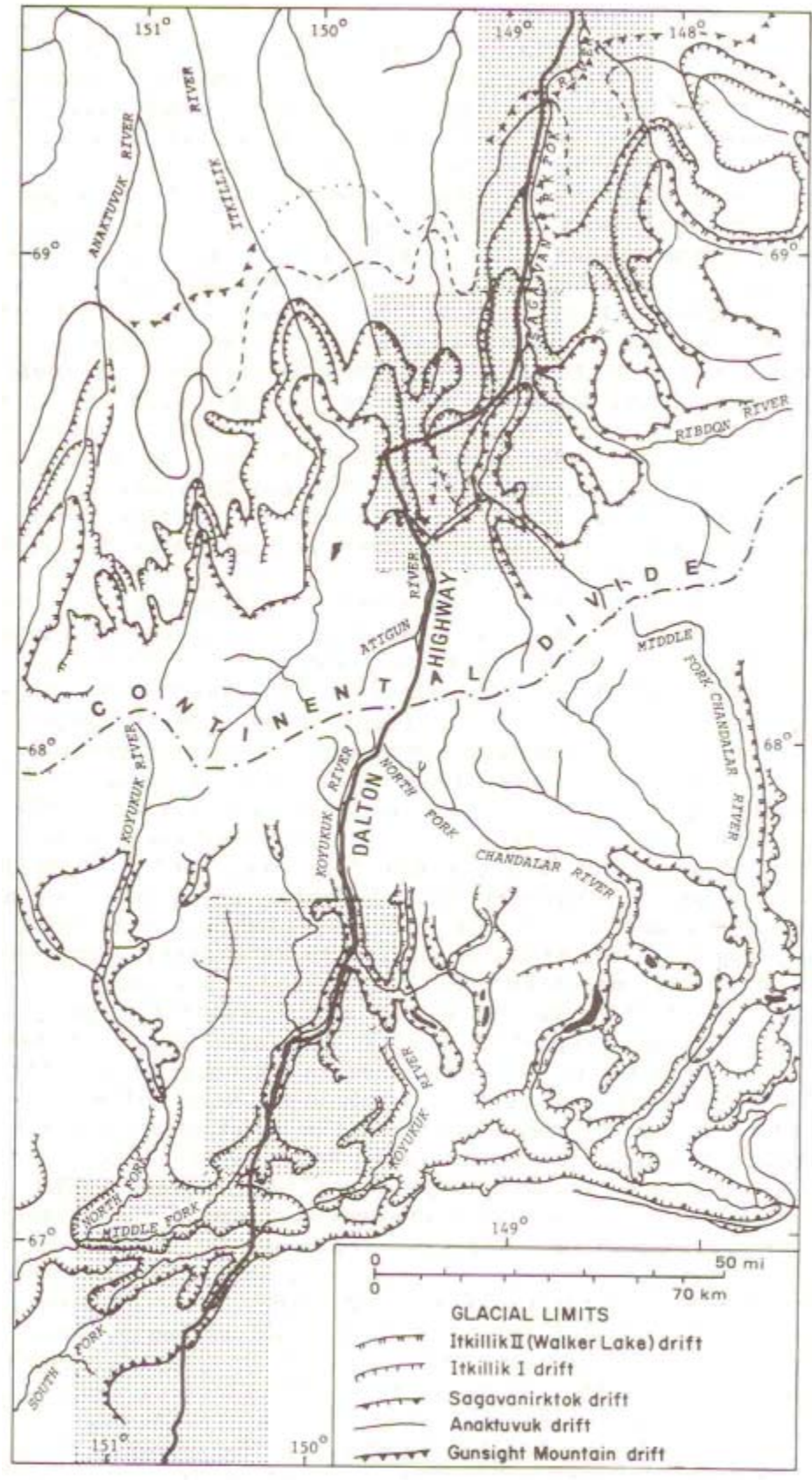

Figure A-4. Extent of glacial deposits along the Dalton Highway. Map by Hamilton $(1978,1979,1982)$ from Brown and Kreig (1983). 
advances occurred from the late Pliocene to as recently as late Holocene (last 4,000-5,000 years). Table A-1 gives the various glacial advance ages and the time of deposition.

The youngest complex of drift sheets generally forms well defined sets of moraines on valley floors. Drift of Sagavanirktok River age is subdued by later dissection, erosion, mass wastage, and loess deposition. Drifts of Itkillik I and II age have progressively sharper and less dissected moraines. Soils that form on the moraines range from poorly drained, ice rich, and fine grained on older moraines with loess cover, to gravelly, lightly oxidized soils on the younger glacial deposits.

The only present-day glaciers in the Brooks Range are cirque glaciers in the higher valley heads at elevations above 1,500 m (4,900 ft). Most occupy northward-facing cirques whose headwalls are deeply shaded from high-latitude (low-angle) solar radiation. Most of these glaciers have been in retreat for about 100-120 years, and currently are retreating rapidly under present-day global warming conditions.

Table A-1. The names and chronology of general glacial deposits in the Brooks Range vicinity

\begin{tabular}{lcc} 
Name of glacial deposit & Age & Time before present (ka) \\
Fan Mountain & Late Holocene & $5-0$ \\
Itkillik II or Walker Lake & Late Wisconsin & $25-12$ \\
Itkillik I & Early Wisconsin & $100-60$ \\
Sagavanirktok Drift & Middle Pleistocene & $780-130$ \\
Anaktuvuk River Drift & Early Pleistocene & $1800-780$ \\
Gunsight Mountain erratics & Late Tertiary & $>1900$ \\
\hline
\end{tabular}

\section{General geomorphology along the route}

The traverse from Fairbanks to Coldfoot through the Brooks Range and out to the coastal plain provides many examples of geomorphologic agents and features. Periglacial processes have shaped (and continue to influence) the landscapes of the Interior and the North Slope. Glacial processes are evident as both active features and as relict landforms close to and extending from the Brooks Range. Mass wasting and fluvial processes dictate the slope morphologies within the confines of the valleys.

From Fairbanks to the southern foothills of the Brooks Range, the landscape is dominated by broadly convex hill slopes and concave lower valley sides that gradually were rounded by solifluction (downhill flow of saturated soils and sediments) over long time intervals. In this area, there is a strong contrast between permafrost presence and depths between north- to east-facing ("cool”) slopes and south- to west-facing ("warm") slopes. Thus, in some cases, dominant slope morphology changes according to slope aspect. This difference is also noted in the vegetation mosaics that blanket the hillslopes. Tors are present on cryoplanation surfaces on uplands south of the Brooks Range. Loess has blanketed many slopes to varying thicknesses, depending on modern and Pleistocene wind regimes and on proximity to sources. Approaching the Brooks Range, the most notable features to be seen are glacial moraines, areas of hummocky drift, outwash terraces, and lacustrine plains that formed during the various ice advances described previously. Slope morphology tends to be steeper and more irregular where glaciers and their meltwater have eroded the smoothly graded solifluction slopes and other forms of colluvium that had accumulated prior to their advances.

The North Slope landscape, devoid of trees and tall brush, provides an excellent view of many geomorphic processes induced by intensely cold and harsh environments. The side slopes of the steep U-shaped valleys are steeply graded, carved out by numerous glacial advances, and are skirted by dramatic colluvial/alluvial fans and talus slopes. Rockfalls and/or slush flows sometimes trail from the very peak of the summit to the footslope position of the surrounding hills, as much as $500 \mathrm{~m}(1,640 \mathrm{ft})$ elevation difference. The streams and rivers often host aufeis (frozen winter overflow ice) that accumulates through the winter and often persists into the late summer. Intensely braided drainage patterns are typical of aufeis areas.

The hydrology of the Brooks Range and North Slope is greatly influenced by the presence of permafrost. You will see outstanding examples of periglacial drainage patterns that once dominated the northern United States during the Pleistocene glaciations. In the uplands and foothills "horsetail drainage" carves out smoothly sweeping arcuate 
patterns that funnel downslope into stream beds. Beaded drainage, formed where streams flow through and melt out ice-wedge polygons, is common on toeslopes and floodplains. Stream discharge is greatest during the spring snowmelt period, when snow wastes rapidly under long daylight hours and meltwater runs off rapidly across the still-frozen ground surface. Streams and rivers typically diminish to much smaller size during mid summer, but may increase again with late-summer storms. On the Arctic coastal plain, thaw lakes become abundant and the landscape becomes generally more poorly drained as the depth to ice-rich permafrost becomes shallower. These wet conditions prevail despite the generally low recorded precipitation.

Patterned ground features and their formation mechanism will be reviewed along the way. The classification of these features is presented in table A-2. These features are particularly noticeable on the open ground of Little Kanuti Flats, the Chandalar Shelf, and the Arctic foothills and coastal plain.

Table A-2. Simplified classification of patterned ground features (Washburn, 1970)

\begin{tabular}{|c|c|c|}
\hline Types & Subtypes & Processes \\
\hline Circles & $\begin{array}{l}\text { Sorted } \\
\text { Non-sorted }\end{array}$ & $\begin{array}{l}\text { Features subdivided on basis of necessity of cracking (frost cracking, } \\
\text { permafrost cracking, dilation, joint control). Where cracking is not } \\
\text { important, heave and mass displacement are prevalent. }\end{array}$ \\
\hline Polygons & $\begin{array}{l}\text { Sorted } \\
\text { Non-sorted }\end{array}$ & $\begin{array}{l}\text { Includes ice and sand wedges. Cracking of all types. Heave, mass } \\
\text { displacement, and thaw processes important in non-cracked types. }\end{array}$ \\
\hline Nets & $\begin{array}{l}\text { Sorted } \\
\text { Non-sorted }\end{array}$ & $\begin{array}{l}\text { Includes earth hummocks. Cracking of all types except joint-controlled } \\
\text { types. Heave and mass displacement in non-cracked types. Thaw also } \\
\text { important in sorted varieties. }\end{array}$ \\
\hline Steps & $\begin{array}{l}\text { Sorted } \\
\text { Non-sorted }\end{array}$ & $\begin{array}{l}\text { Cracking unimportant. Heave, mass wasting, and displacement in } \\
\text { nonsorted. Frost sorting and thaw also important in sorted varieties. } \\
\text { Terracette (sheep-step) form. }\end{array}$ \\
\hline Stripes & $\begin{array}{l}\text { Sorted } \\
\text { Non-sorted }\end{array}$ & $\begin{array}{l}\text { All types of cracking important. Heaving, mass wasting, and } \\
\text { displacement in nonsorted. Frost sorting and thaw also important in } \\
\text { sorted types. }\end{array}$ \\
\hline
\end{tabular}

\section{References}

Brown, J., and Kreig, R.A., eds., 1983, Guidebook to permafrost and related features along the Elliott and Dalton Highways, Fox to Prudhoe Bay: Alaska Division of Geological \& Geophysical Surveys Guidebook 4, 230 p. Mull, C.G., 1989, Generalized stratigraphy and structure of the Brooks Range and Arctic Slope, in Mull, C.G., and Adams, K.E., eds., Bedrock geology of the eastern Koyukuk Basin, central Brooks Range, and eastcentral Arctic Slope along the Dalton Highway, Yukon River to Prudhoe Bay, Alaska: Alaska Division of Geological \& Geophysical Surveys Guidebook 7, v. 1, p. 31-46.

Mull, C.G., and Adams, K.E., 1989, Bedrock geology of the eastern Koyukuk Basin, central Brooks Range, and eastcentral Arctic Slope along the Dalton Highway, Yukon River to Prudhoe Bay, Alaska: Alaska Division of Geological \& Geophysical Surveys Guidebook 7, v. 1, 309 p., 1 sheet, scale 1 inch $=45$ miles.

Pearson, R.W., and Hermans, Marjorie, eds., 2003, Alaska in maps, 4th Edition: Anchorage, Alaska, Alaska Geographic Alliance, CD-ROM.

Washburn, A.L., 1956, Classification of patterned ground and review of suggested origins: Geological Society of America Bulletin, v. 67, p. 823-866.

Washburn, A.L., 1970, An approach to genetic classification of patterned ground: Acta Geographica Lødzienska, v. 24, p. 437-446.

Washburn, A.L., 1980, Geocryology—A survey of periglacial processes and environments (2nd ed.): New York, John Wiley \& Sons, Halsted Press, 406 p. 


\title{
APPENDIX B Soils of Alaska along the 2008 NICOP Field Excursion
}

\author{
C.L. Ping, Professor of Soil Science, Agricultural and Forestry Experiment Station, \\ University of Alaska Fairbanks
}

\section{Interior Alaska \\ Soil-Forming Factors of the Boreal Forest}

The Fairbanks area is in the center of Interior Alaska, which consists of several broad, nearly level lowlands with elevations mostly below $500 \mathrm{~m}(1,640 \mathrm{ft})$ and rounded mountains with elevations up to about 1,000 $\mathrm{m}(3,300$ $\mathrm{ft}$ ). The uplands are dominated by boreal forest, mainly conifer forest with small patches of deciduous forest. The lowlands are locally referred as "muskegs" that consist of bogs and forested bogs. This region has discontinuous permafrost (Brown and others, 1997). Climate is continental, with mean temperatures at valley bottom stations ranging from 15 to $17^{\circ} \mathrm{C}\left(59\right.$ to $\left.63^{\circ} \mathrm{F}\right)$ in July, from -23 to $-28^{\circ} \mathrm{C}\left(-9\right.$ to $\left.-20^{\circ} \mathrm{F}\right)$ in January, and -2.5 to $-6^{\circ} \mathrm{C}(27$ to $21^{\circ} \mathrm{F}$ ) annually (Owenby and Ezell, 1992). Mean annual soil temperatures at the upper permafrost ranges -2 to $0^{\circ} \mathrm{C}\left(28\right.$ to $\left.32^{\circ} \mathrm{F}\right)$ (Brown and others, 1997; Osterkamp and Romanovsky, 1999). Mean annual precipitation ranges from about 23 to $34 \mathrm{~cm}$ (9 to $13.5 \mathrm{in}$ ) (National Climatic Data Center, 2004). While precipitation totals are low, the abundant surface water and predominance of acid soils over most of the area indicate an excess of annual precipitation over evapotranspiration. The bedrock consists of crystalline igneous and metamorphic rocks and non-calcareous sedimentary rocks (Beikman, 1980) with a loess cover that ranges from many meters thick near

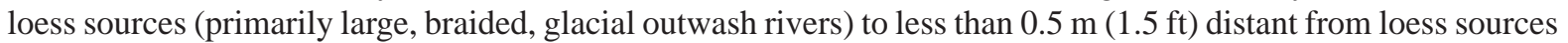
(Péwé, 1975). Pleistocene glaciation was limited to a few high cirques (Coulter and others, 1965). Landform plays the controlling role in soil formation in the boreal region of interior Alaska. The landform factor, acting through slope aspect, redistributes the climatic attributes, especially solar energy and precipitation. As a result, different vegetation communities develop on different aspects and feed back to soil formation. Even though the area was not glaciated, the degree of soil formation does not increase with time because of the constant addition of eolian dust.

\section{Soil Types and Distribution in the Boreal Region}

The soil catena in Interior Alaska was described by Rieger and others (1963), Furbush and Schoephorster (1977), and Viereck and others (1983). In general, well-drained soils associated with white spruce and deciduous trees occur on southerly slopes and floodplains, permafrost-laden soils associated with black spruce are on north-facing slopes, and poorly-drained soils associated with stunted spruce, shrubs, and bogs occur in lowlands and broad valleys.

Soils on the south aspect formed in a relatively drier, warmer microclimate than those formed on north aspects or floodplains. They have thinner $(<12 \mathrm{~cm}[<4.7 \mathrm{in}])$ and less humified $\mathrm{O}$ horizons and a weakly weathered subsurface horizon with a grayish brown color, indicating release of iron from primary minerals, a process called brunification; thus they are keyed into the Inceptisols order (Soil Survey Staff, 2006). The poorly drained Inceptisols formed under mean annual soil temperature (MAST) of $<8^{\circ} \mathrm{C}\left(46^{\circ} \mathrm{F}\right)$ are Cryaquepts. The well-drained cold Inceptisols are Cryepts. The vegetation on the well-drained south slopes is dominated by white spruce (Picea glauca) intermixed with paper birch (Betula neoalaskana). Soils around the Fairbanks area have deep loess deposits and are only weakly leached. As a result, they retain most of the exchangeable cations and the base saturation is greater than 50 percent; they are classified as Haplocryepts. In areas north of Fairbanks where the loess mantle

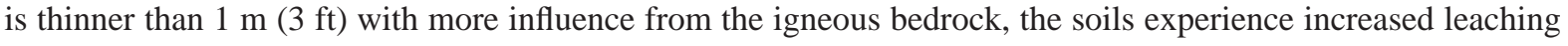
and the base saturation is less than 50 percent; the soils are classified as Dystrocryepts. It is common to find pure aspen stands (Populus tremuloides) on the exposed or dry ridge tops. Because of the annual input of litter and minimum leaching on the summit position, the soils are base-rich and often have a dark surface horizon, thus they are classified as Humicryepts and Lithic Haplocryepts where the bedrock is less than $50 \mathrm{~cm}(<20 \mathrm{in})$ deep (Ping and others, 2004).

Soils on the north aspect formed in a relatively wetter, colder microclimate that resulted in increased accumulation of organic matter and a reducing condition. The thick $\mathrm{O}$ horizon contributes to the development and maintenance of permafrost that in turn affects soil formation. In addition, the decomposed organic matter produces organic acids that neutralize the carbonates in the loess parent material and thus contribute to the soil acidity. But the most widespread soils with permafrost are fine-grained loess and colluvial deposits on toe slopes and broad 
valleys. These permafrost-affected soils are classified in the Gelisol order (Soil Survey Staff, 2006). Those with more than $40 \mathrm{~cm}$ (16 in) of organic horizons key into the Histel suborder. On north-facing slopes having a slope up to 40 percent and on foot slopes, the soils generally have a thick $\mathrm{O}$ horizon (but $<40 \mathrm{~cm}$ [ $<16 \mathrm{in}]$ ), gleyed mineral soil, and permafrost at about $0.5 \mathrm{~m}$ (18 in) depth. Those soils with no or minimum cryoturbation are classified as Typic Historthels. On some slopes there is evidence of solifluction/gelifluction in the soil profile induced by slope movement after forest fire, and these soils are classified as Typic Histoturbels. Occasionally frost mounds are found in valley floors and exposed slopes and the surface organic horizons are discontinuous or vary greatly across a short distance; these soils are classified as Ruptic Histoturbels (Swanson, 1996a). On steep north-facing slopes where the fractured bedrock is within $50 \mathrm{~cm}$ (20 in) of the mineral surface, soils are classified as Lithic Historthels (Ping and others, 2005a).

Histels form in poorly to very poorly drained bogs or fens in lowlands, broad valleys, and river terraces,

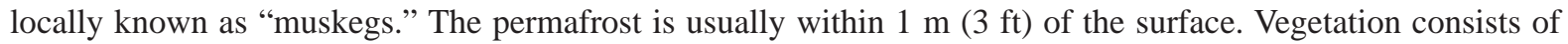
sparse, stunted black spruce (Picea mariana) with low shrubs, sedges, and mosses (including Sphagnum spp. and others). The Histel suborder is further subdivided into four great groups. On the poorly drained gentle foot slopes and toe slopes, the highly decomposed organic matter has a muck texture and the soils are classified as Sapristels. On the lower toe slope and toward the edge of the bog, where the organic matter is partially decomposed, they are classified as Hemistels. In the bog and under open water, the organic horizon consists of sedge peat and soils

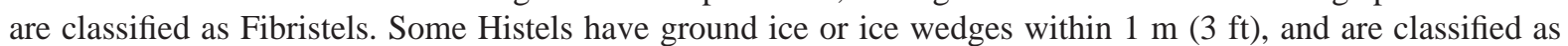
Glacistels. Thus, within the micro-drainage sequence, the degree of organic matter decomposition decreases from poor at high positions to very poor at the center of the bog or lowland.

Interior Alaska soils with permafrost can change markedly in response to forest fires or other disturbance and post-fire plant succession. Active-layer thickness often increases greatly after fire, from about $0.5 \mathrm{~m}$ (18 in) to 2 m (6.5 ft) or more (Dyrness, 1982; Viereck, 1970), soils become drier, and oxidation of previously reduced soils may occur. The soils that show the greatest change after fires are those at the warmest and driest end of the continuum of permafrost soils before the fire (Swanson, 1996b). In some cases, retreat of the permafrost table below $2 \mathrm{~m}$ (6.5 ft) depth after disturbance can cause the soil classification to change greatly, from Gelisols to Inceptisols (Ping and others, 2005c).

\section{Arctic Coastal Plain}

\section{Soil-Forming Factors of the Arctic Coastal Plain}

This treeless area is characterized by multiple thaw lakes, many of them elongated in a north-northwesterly direction perpendicular to the prevailing winds. As much as 40 to 50 percent of the surface area is water. Low terraces, broad shallow depressions, and floodplains are typical of the landscape. Periglacial features include frost polygons, hummocks, nonsorted circles (frost boils), and pingos. The drainage is poor or very poor. The dominant vegetation includes water sedge (Carex aquatilis), cottongrass (Eriophorum angustifolium), and mosses (Tomentypnum nitens, Drepanocladus spp., and Scorpidium scorpioides) (Walker, 1999). The major landforms are alluvial fans and the parent materials are carbonate-rich alluvium deposited by the meandering arctic rivers since the late Pleistocene (Brown and Kreig, 1983). The climate of the area varies with distance from the Arctic Ocean and elevation. On the Arctic coastal plain the mean annual air temperature (MAAT) ranges from -12.8 to $-10.3^{\circ} \mathrm{C}(9$ to $13.5^{\circ} \mathrm{F}$ ), and mean annual precipitation (MAP) ranges from 125 to $142 \mathrm{~mm}$ (4.9 to 5.6 in) with 50 percent as snow (Haugen, 1982). The mean annual soil temperature (MAST) at $50 \mathrm{~cm}$ (19.7 in) estimated from the temperatures of permafrost ranges from -9 to $-7^{\circ} \mathrm{C}\left(16\right.$ to $\left.19^{\circ} \mathrm{F}\right)$ (Osterkamp and Romanovsky, 1996).

\section{Soils of the Arctic Coastal Plain}

Everett and Brown (1982) summarized the early research on soil characterization, classification, and mapping of tundra soils in Arctic Alaska. The Arctic Coastal Plain is dominated by thaw lake basins, characterized by patterned ground ranging from high-centered polygons to low-centered polygons to poorly-drained peat ridges. Everett and Brown (1982) recognized four orders in Soil Taxonomy before the Gelisol order was adopted (Soil Survey Staff, 1975): Entisols, Inceptisols, Histosols, and Mollisols. In the 1975 soil classification system, soils affected by permafrost were recognized at the pergelic subgroup level in that the MAST is at or lower than $0^{\circ} \mathrm{C}\left(32^{\circ} \mathrm{F}\right)$ at $50 \mathrm{~cm}$ (19.7 in). However, this criterion does not separate the soils with permafrost from those without. This is particularly true in alpine soils and alluvial soils in the Arctic, where solar energy in the summer may penetrate to

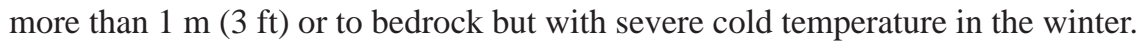

In the newly-formed poorly-drained alluvial terraces, fans, or newly-drained thaw lake basins, poorly-defined peat ridges or flat polygons form. There is minimal cryoturbation and the dominant soils are Histic Aquorthels or 
Typic Historthels (previously Histic Pergelic Cryaquepts). These soils consist of stratified peat and loamy sediments over loamy alluvium or lacustrine sediment with grayish or bluish-gray colors. The active layer is about $40 \mathrm{~cm}$ (16 in) thick and the upper permafrost is ice rich with thick ice lenses. Fibristels or Glacistels are found in the wet sedge meadows (Ping and others, 2008). When the ice wedge formation progresses, the polygons become low-centered. Cryogenic processes can also form nonsorted circles. The dominant cryoturbated soils are Histic Aquiturbels where the $\mathrm{O}$ horizons are less than $15 \mathrm{~cm}$ (6 in), and Typic Histoturbels where the $\mathrm{O}$ horizons are more than $15 \mathrm{~cm}$ (6 in) (Ping and others, 2004). Soils formed on polygon rims generally consist of 15-20 cm (6-8 in) of organic material over 20-30 cm (8-12 in) over a gleyed mineral horizon. The permafrost table is at $45-50 \mathrm{~cm}$ (18-20 in), and the upper permafrost contains more than 60 percent ice by volume. Soil horizons in the polygon rim show a convex pattern following the surface relief of the rim; thus the soils are cryoturbated and are classified as Histic Aquiturbels. Soils in the troughs between polygons are very poorly drained and are characterized by 35-40 cm (14-16 in) of organic horizon over an ice wedge; these are organic soils and classified as Fibric Glacistels. High-centered polygons developed due to melting ice wedges. The mounded centers became better drained, thus a dark humus-rich mineral horizon formed. These soils were previously classified as Pergelic Cryaquolls and are now either Aquic Molliturbels or Mollic Aquiturbels (Ping and others, 2004). Similar soils are also found on raised levees such as west of Franklin Bluff or old terraces on the coastal plain. Most of the soils on the coastal plain along the Sagavanirktok River are base-rich, thus they are either neutral or slightly alkaline (Ping and others, 2005b).

\section{Arctic Foothills}

\section{Soil-Forming Factors of the Arctic Foothills}

The Arctic Foothills cover an area between the northern foot slopes of the Brooks Range and the Arctic Coastal Plain. The foothills are characterized by broad, sloping valleys separated by moderately steep to steep ridges, hills, and knolls. Elevations range from 100 to about $900 \mathrm{~m}$ (330 to 3,000 ft) and these areas are within the zone of continuous permafrost. There are two major land cover types in the region: moist nonacidic tundra (MNT) and moist acidic tundra (MAT). The MNT is dominated by mixed dwarf shrub-sedge (Dryas integrifolia, Salix reticulata, Carex bigelowii, and Tomentypnum nitens), and the MAT by mixed cottongrass-shrub (Eriophorum vaginatum, Betula nana, Salix pulchra, Sphagnum spp., and Hylocomium splendens) (Walker, 1999). The dominant parent material is loess on the northern foothills and moraine in the southern part. The mean annual air temperature (MAAT) of the Arctic foothills is $2-4^{\circ} \mathrm{C}\left(3.6-7.2^{\circ} \mathrm{F}\right)$ warmer than that of the coastal plain due to the greater distance from the ocean (Zhang and others, 1996). The mean annual soil temperature (MAST) ranges from -7 to $-5^{\circ} \mathrm{C}\left(39.2-19.4^{\circ} \mathrm{F}\right)$, and the mean annual precipitation (MAP) ranges from 140 to $270 \mathrm{~mm}$ (5.5-10.6 in) with 40 percent falling as snow (Haugen, 1982). In general, MAP and diurnal temperature variations increase southward with distance from the coast.

\section{Soils of the Arctic Foothills}

The microrelief of the Arctic foothills is characterized by nonsorted circles or frost boils that occupy about 40 percent of the land surface with tussock tundra around them (Ping and others, 2008). Most soils are highly cryoturbated as indicated by warped and broken soil horizons occurring throughout the entire profile, and thus key into the Turbel suborder of Gelisols. The Sagwon Hills encompasses the northern portion of the Arctic Foothills. Along the northern edge of this hilly upland, the vegetation is dominantly nonacidic tundra (Bockheim and others, 1998) characterized by Dryas integrifolia and Lupinus arcticus, in addition to other tundra types. Under a discontinuous organic layer, portions of the profile have a high chroma color, indicating oxidation of iron minerals, while adjacent zones are gleyed. The dominant soils in the nonsorted circles with minimum vegetation cover having an A horizon are Aquic Molliturbels because the redoximorphic features are $50 \mathrm{~cm}$ (19.7 in) below the mineral surface. In some areas the organic horizons increase more than fourfold in thickness from the center of the circle to the intercircle area, and the redoximorphic features develop just below the organic horizons. These soils are classified as Ruptic-Histic Aquiturbels (Ping and others, 1998). Cryoturbated organic matter or humus is distributed in the lower active layer and upper permafrost, and forms a second concentration of organic matter at depth between 80 and $120 \mathrm{~cm}$ (31.5 and 47.2 in). This suggests the frost churning of humus and sequestration of carbon into the permafrost (Ping and others, 1998).

On similar landforms and loess parent materials farther to the south, the vegetation changes to moist acidic tundra (MAT). The nonsorted circles are close-packed under the tussock tundra and the exposed mineral soil is less than 15 percent of the land surface. Soils associated with this land cover have an organic horizon with thickness ranging from 0 to $40 \mathrm{~cm}$ (0-16 in). As in MNT soils, cryoturbated organic matter or humus is found churned into the lower active layer and upper permafrost and forms a second concentration of organic matter, but at shallower 
depth, between 50 and $90 \mathrm{~cm}$ (19.7 and 35.4 in). These soils are dominantly Ruptic Histoturbels and Ruptic-Histic Aquiturbels. In the acidic tundra there is better moss growth; hence there is a thicker organic horizon. In both soils the upper permafrost layers have an ataxitic fabric with ice content generally 60 percent or more by volume. Soils associated with MAT have base saturation less than 30 percent, indicating increased acidification due to organic horizon build-up and loss of bases through slope runoff on the upland position (Ping and others, 2005b).

Soil texture suggests a uniform parent material for soils in the northern Arctic foothills. The predominantly silt loam textures in both acidic and nonacidic tundra suggest a common source-loess. Soil textures change from silt loam to loam or silty clay loam in the southern part of the foothills due to the shifting of parent materials from loess to glacial drift of Middle or Late Wisconsin age (Hamilton, 1987) and contains coarse fragments ranging in size from pebbles to boulders.

Histels formed in the valley floors or depressions among the foothills. Because of the cold and wet environment, the organic horizons are mostly fibrous and partially decomposed material and are thus classified as Fibristels or Hemistels. Where the organic layers formed over ice wedges the soils are classified as Glacic Fibristels, where the organic layers were deposited with stratified mineral soils on uplands, the soils are classified as Terric Hemistels. In some areas the organic deposits may exceed $3 \mathrm{~m}$ (10 ft) in depth (Brown and Kreig, 1983).

Three soil orders were mapped by Rieger and others (1979) on the Arctic Slope of Alaska: Inceptisols, Histosols, and Mollisols. The presence of permafrost was not recognized in the classification system until the introduction of the Gelisol order, when the characteristic differentiations of these three orders were expressed at the suborder level (Histels) and great group levels (that is, Aquiturbels, Molliturbels). Some soils that formed on gravelly

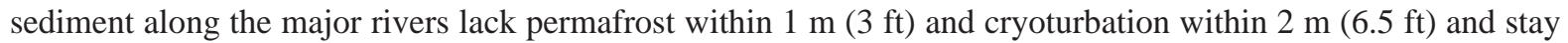
in the Entisol order. The loamy-textured soils along coastal estuaries are Gelaquents and the sandy ones formed in braided river channels are Gelorthents. In the alpine area of the North Slope and Brooks Range, the soils are generally shallow, $<50 \mathrm{~cm}(<20 \mathrm{in})$ over paralithic or lithic contact. Although the MAST is $<0^{\circ} \mathrm{C}\left(<32^{\circ} \mathrm{F}\right)$ there is no permafrost within the soil profile, thus they are keyed into Lithic Dystrogelepts.

\section{Dominant Soil Processes and Soil Taxonomy}

Soil Taxonomy (Soil Survey Staff, 2006), the U.S. soil classification system, recognizes cryogenesis as the controlling soil-forming factor in permafrost-affected soils. The Gelisol order was adopted to encompass permafrost-affected soils. In newly formed Gelisols that lack cryoturbation, the soils key into the Orthel suborder. The presence of permafrost and the associated cryogenic processes such as frost heaving lead to cryoturbated soil profiles and a unique set of morphological properties. Cryoturbation causes mixing of soils materials and minimizes leaching effects, and, most importantly, sequesters organic carbon to deeper parts of the profile. These soils key into the Turbel suborder.

The accumulation of organic matter due to the cold, wet environment leads to unusual amounts of organic carbon storage in arctic soils (Michaelson and others, 1996). Soils with $>40 \mathrm{~cm}(>15.7 \mathrm{in})$ of organic horizons key into the Histel suborder. In carbonate-rich environments such as the Arctic coastal plain and northernmost foothills regions, the humus is stabilized by abundant base ions such as $\mathrm{Ca}$ and $\mathrm{Mg}$ that form stable complexes in the A horizons. In the foothills where there is increased annual temperature and precipitation, there is increased leaching and loss of bases due to paludifucation from hydrogen ions produced by the moss vegetation. The review by Everett and Brown (1982) indicated that there is negligible chemical weathering in Arctic coastal tundra. Yet, the acidification that led to the weathering of primary minerals in the upper profile is evident by the redoximorphic features. The lower active layers and the upper permafrost are highly reduced, evident by the gleyed color. The dominant weathering process is the reduction of Fe and Mn from primary minerals due to anaerobic conditions. Although the tundra soils studied in Arctic Alaska have mixed clay mineralogy, these clays are not pedogenic but rather are from the parent material. Soil acidification has only resulted in hydrated interlayer vermiculite (Borden and others, 2004).

\section{References}

Beikman, H.M., 1980, Geologic map of Alaska: U.S. Geological Survey Special Map, scale 1:2,500,000, 2 sheets.

Borden, P.W., Ping, C.L., and McCarthy, P.J., 2004, Effect of pH on clay mineralogy in Gelisols of Sagwon Hills, Alaska: Madison, WI, Annual Meeting Abstracts, American Society of Agronomy, www.asa-cssa-sssa.org/

Bockheim, J.G., Walker, D.A., Everett, L.R., Nelson, F.E., and Shiklomanov, N.I., 1998, Soils and cryoturbation in moist nonacidic and acidic tundra in the Kuparuk River basin, Arctic Alaska, USA: Arctic Alpine Research, v. 30, p. 166-174. 
Brown, Jerry, and Kreig, R.A., eds., 1983, Guidebook to permafrost and related features along the Elliott and Dalton Highways, Fox to Prudhoe Bay: Alaska Division of Geological \& Geophysical Surveys Guidebook 4, 230 p.

Brown, J., Ferrians, O.J., Heginbottom, J.A., and Melnikov E.S., 1997, Circum-arctic map of permafrost and ground-ice conditions: U.S. Geological Survey Map CP-45, scale 1:10,000,000.

Coulter, H.W., Hopkins, D.M., Karlstrom, T.N.V., Péwé, T.L., Wahrhaftig, C., and Williams, J.R., 1965, Extent of glaciation in Alaska: U.S. Geological Survey Miscellaneous Geologic Investigations Map I-415, Scale $1: 2,500,000$.

Dyrness, C.T., 1982, Control of depth to permafrost and soil temperature by the forest floor in Black Spruce/ Feathermoss communities: U.S. Forest Service, Research Note PNW-396, Pacific Northwest Forest and Range Experiment Station, Portland, OR

Everett, K.R., and Brown, J., 1982, Some recent trends in the physical and chemical characterization and mapping of tundra soils, Arctic Slope of Alaska: Soil Science, v. 133, p. 264-280.

Furbush, C.E., and Schoephorster, D.B., 1977, Soil survey of Goldstream-Nenana area, Alaska: U.S. Soil Conservation Service, U.S. Government Printing Office, Washington, DC, 44 p.

Hamilton, T.D., 1987, Surficial geologic map of the Philip Smith Mountains Quadrangle, Alaska. U.S. Geological Survey Miscellaneous Field Studies Map MF-879A, Scale 1:125,000, 1 p.

Haugen, R.K., 1982, Climate of remote areas in north-central Alaska, 1975-1979 Summary: Hanover, NH, U.S. Army Cold Regions Research and Engineering Laboratory Report 82-35, 114 p.

Michaelson, G.J., Ping, C.L., and Kimble, J.M., 1996, Carbon storage and distribution in tundra soils of arctic Alaska, USA: Arctic and Alpine Research, v. 28, no. 4, p. 414-424.

National Climatic Data Center, 2004, Climatological Data Annual Summary, Alaska: Asheville, NC, National Oceanic and Atmospheric Administration.

Osterkamp, T.E., and Romanovsky, V.E., 1996, Characteristics of changing permafrost temperatures in the Alaskan Arctic, USA: Arctic Alpine Research, v. 28, p. 267-273.

Osterkamp, T.E., and Romanovsky, V.E. 1999, Evidence for warming and thawing of discontinuous permafrost in Alaska: Permafrost and Periglacial Processes, v. 10, p. 17-37.

Owenby, J.R., and Ezell, D.S., 1992, Monthly station normal of temperature, precipitation, and heating and cooling degree-days, 1961-1990; Alaska: Asheville, NC, National Oceanic and Atmospheric Administration, National Climatic Data Center, Climatography of the United States, no. 81.

Péwé, T.L., 1975, Quaternary geology of Alaska: U.S. Geological Survey Professional Paper 835, 145 p.

Ping, C.L., Bockheim, J.G., Kimble, J.M., Michaelson, G.J., and Walker, D.A., 1998, Characteristics of cryogenic soils along a latitudinal transect in Arctic Alaska: Journal of Geophysical Research, v. 103, no. D22, p. 917-928.

Ping, C.L., Swanson, D.K., and Clark, M.H., 2004, Cryosols in Alaska. in Kimble, J., ed., Cryosols; Permafrostaffected soils: New York, Springer-Verlag, p. 71-94.

Ping, C.L., Jorgenson, T., Lynn, L.A., and Michaelson, G.J., 2008, Classification of Arctic tundra soils along the Beaufort Sea coast, Alaska, in Proceedings of the 9th International Conference on Permafrost, June 29-July 3, 2008: Fairbanks, AK, University of Alaska Fairbanks, p. 1,423-1,426.

Ping, C.L., Michaelson, G.J., Packee, E.C., Stiles, C.A., Swanson, D.K., and Yoshikawa K., 2005a, Characterization and formation of soils in the Caribou-Poker Creek Research Watershed, Alaska: Soil Science Society of America Journal, v. 69, p. 1,761-1,772.

Ping, C.L., Michaelson, G.J., Kimble, J.M., and Walker D.A., 2005b, Soil acidity and exchange properties of cryogenic soils in Arctic Alaska: Soil Science and Plant Nutrition, v. 51, no. 5, p. 649-653.

Ping, C.L., Boone, R., Clark, M.H., Packee, E.C., and Swanson, D.K., 2005c, State factor control of soils formation in Interior Alaska, in Chapin, F.S., III, Oswood, M. Van Cleve, K., Viereck, L., and Verbyla, D., eds., Alaska’s Changing Boreal Forest: New York, Oxford University Press, p. 21-38.

Rieger, S., DeMent, J.A., and Sanders, D., 1963, Soil survey of Fairbanks area, Alaska: U.S. Soil Conservation Service.

Rieger, S., Schoephorster, D.B., and Furbush, C.E., 1979, Exploratory soil survey of Alaska: U.S. Soil Conservation Service.

Soil Survey Staff, 1997, Soil Taxonomy: Washington, DC, U.S. Government Printing Office, USDA Soil Conservation Service, Agriculture Handbook No. 436.

Soil Survey Staff, 2006, Keys to Soil Taxonomy; 10th edition: USDA Natural Resources Conservation Service, Washington, D.C. 
Swanson, D.K., 1996a, Soil geomorphology on bedrock and colluvial terrain with permafrost in central Alaska, USA: Geoderma, v. 71, p. 157-172.

Swanson, D.K., 1996b, Susceptibility of permafrost soils to deep thaw after forest fire in interior Alaska, USA, and some ecologic implications: Arctic and Alpine Research, v. 28, no. 2, p. 217-227.

Viereck, L.A., 1970, Forest succession and soil development adjacent to the Chena River in interior Alaska: Arctic and Alpine Research, v. 2, no. 1, p. 1-26.

Viereck, L.A., Dyrness, C.T., Van Cleve, K., and Foote, M.J., 1983, Vegetation, soils, and forest productivity in selected forest types in interior Alaska: Canadian Journal of Forest Research, v. 13, p. 703-720.

Walker, D.A., 1999, An integrated mapping approach for northern Alaska: International Journal of Remote Sensing, v. 20, p. 2,895-2,920.

Zhang, T., Osterkamp, T.E., and Stamnes, K., 1996, Some characteristics of the climate in northern Alaska, USA: Arctic and Alpine Research, v. 28, no. 4, p. 509-518. 


\title{
APPENDIX C Stop 31: Happy Valley Active-layer studies and the CALM network
}

\author{
Fritz Nelson and Kolia Shiklomanov (University of Delaware) and Ken Hinkel (University of Cincinnati)
}

Happy Valley is the site of one of the Circumpolar Active Layer Monitoring (CALM) program's original installations in northern Alaska. CALM is an international global-change monitoring program concerned with the dynamics of the active layer and upper permafrost, and with long-term trends in temperature, thaw subsidence, and active-layer thickness. It is focused primarily on permafrost environments, and its mission includes data collection, management, and dissemination. The CALM network currently includes more than 150 sites in both polar regions, as well as in selected mid-latitude mountain regions. Extensive information about the CALM program and network can be found in Brown and others (2000) and online at http://www.udel.edu/Geography/calm/.

The ARCSS/CALM grid at Happy Valley is one of five $1 \times 1 \mathrm{~km}(0.6 \times 0.6 \mathrm{mi})$ arrays of precisely surveyed sampling grids in the Kuparuk region. Each array consists of 121 sampling locations, separated from one another by $100 \mathrm{~m}$ (330 ft). Grids were initiated at Toolik Lake and Imnavait Creek under the U.S. Department of Energy R4D during the late 1980s, and at Happy Valley, West Dock, and Betty Pingo under NSF's Flux Study (Weller and others, 1995) in the mid 1990s. The grids form a regional (N-S) transect through the continuous permafrost zone, from Prudhoe Bay to the northern foothills of the Brooks Range. The grids have been used as sampling frameworks for a variety of topical investigations and continue to form a core element of Circumpolar Active Layer Monitoring (CALM) investigations in north-central Alaska (Hinkel and Nelson, 2003). A second transect of ARCSS/CALM grids, $150 \mathrm{~km}(94 \mathrm{mi})$ to the west, consisting of installations at Barrow, Atqasuk, and Ivotuk, was created in the 1990s. Large $(1 \times 1 \mathrm{~km}[0.6 \times 0.6 \mathrm{mi}])$ grids have also been installed at Council and Kougarok on the Seward Peninsula (Overduin and Hinzman, 2002). Active-layer thickness (ALT) has been measured annually near the end of the thaw season (late August/early September) at each of the grids on the North Slope since 1995 (fig. C-1). Data records for the entire measurement period can be found on the CALM web site, at the address given above.

The ARCSS/CALM grids encompass specific combinations of landscape elements, chosen to provide integrated and representative examples of local topographic, vegetative, geomorphic, and edaphic conditions. At the time Flux Study investigations were initiated, however, little information about the geographic and temporal variability of ALT measurements existed, and concerns were raised that a $100 \mathrm{~m}$ (330 ft) sampling interval was inadequate to assess them. A series of sampling experiments performed in the early 1990s used simulated ALT fields incorporating regularities corresponding to such known spatial periodicities as tundra tussocks, ice-wedge polygons, and drained thaw lakes. Simultaneously, a variety of spatial sampling schemes were evaluated in the field at the various $1 \times 1 \mathrm{~km}(0.6 \times 0.6 \mathrm{mi})$ grids. Both simulations and field data indicated that sampling at equidistant $100 \mathrm{~m}$ (330 ft) intervals provided good estimates of central tendency and dispersion (i.e., statistical moments) for use in summarizing annual ALT measurements, but that the method could not produce adequate information for mapping ALT at some of the grids, particularly those in the Arctic foothills physiographic province.

Subsequent work (Gomersall and Hinkel, 2001; Hinkel and Nelson, 2003) demonstrated that the scale of maximum ALT variability differs substantially between the Arctic foothills and the Arctic coastal plain physiographic provinces. At the West Dock, Betty Pingo, Atqasuk, and Barrow sites, large differences in ALT are associated with the arrangement of drained thaw lakes with spacing of 100-300 m (330-980 ft), while in the foothills large variations in active-layer thickness occur over distances of only 1-30 m (3-100 ft), in association with tundra tussocks, water tracks, and topoclimatic influences. These factors are all well developed within the area of the Happy Valley grid. Figure C-2 illustrates differences in variability in the foothills and coastal plain provinces.

The overarching goal of active-layer investigations in the Flux Study was to obtain accurate regional estimates of the volume of thawed soil in the Kuparuk region. Intensive investigations were performed in a series of 1 ha (2.5 ac) plots representing vegetation/soil units common in the watershed. Using ALT values obtained from the Flux Study plots, air and ground-surface temperature data collected over the $200 \mathrm{~km} \mathrm{(125} \mathrm{mi)} \mathrm{transect} \mathrm{between}$ Prudhoe Bay and Toolik Lake, summer lapse rates, a digital map of vegetation/soil conditions, and a digital elevation model, Nelson and others (1997) constructed a detailed map of end-of-season ALT for the Kuparuk region (fig. C-3). A helicopter-based validation study (Muller and others, 1998) confirmed the map's high degree of accuracy. $\mathrm{N}$-factor data collected from natural landscape units in the Kuparuk region have also been used to map ALT at the regional scale, with a similar degree of accuracy (Klene and others, 2001a, 2001b). Shiklomanov and Nelson 


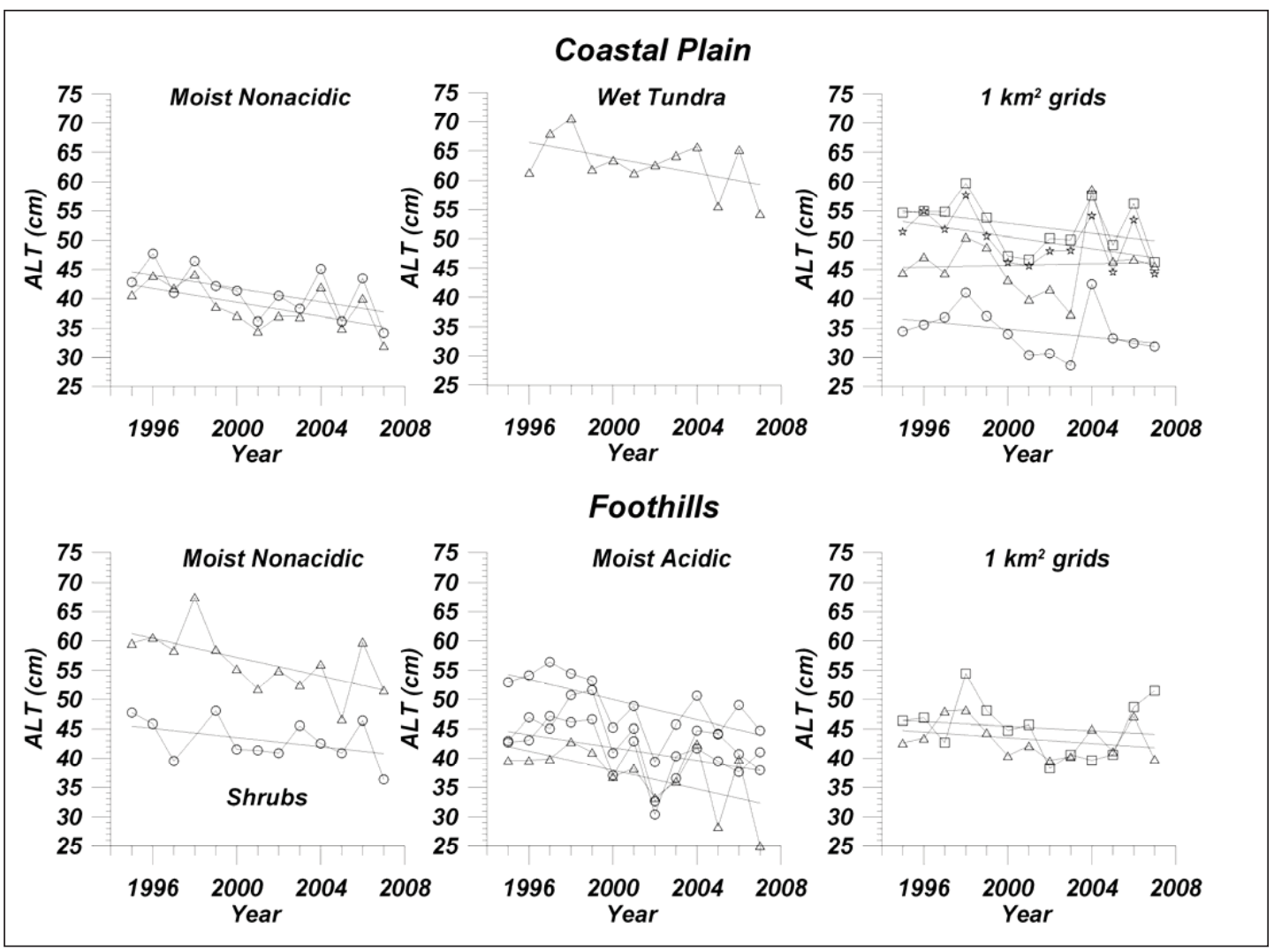

Figure C-1. Site-specific 13-year (1995-2007) records of annual active-layer thickness. Nine 1 ha Flux Study Plots are grouped by landscape categories characteristic of the Foothills and coastal plain physiographic provinces. Six of the $1 \mathrm{~km}^{2}$ ARCSS/CALM grids are grouped by physiographic provinces. Happy Valley is represented by squares in the lower right diagram. Data from the Imnavait $1 \mathrm{~km}^{2}$ site are not shown. From Streletskiy and others (2008).

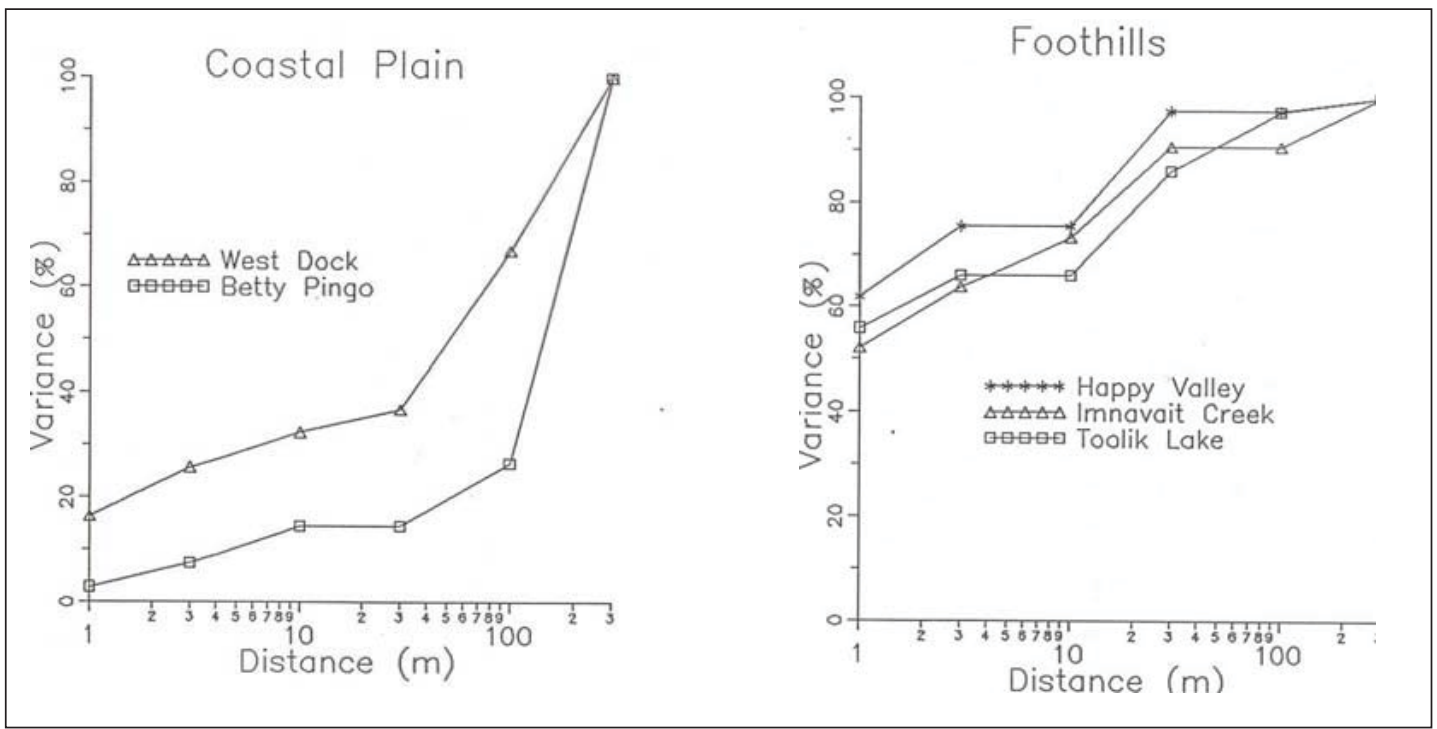

Figure C-2. Active layer thickness (ALT) variability in two physiographic provinces of north-central Alaska. On the coastal plain (left), the "reconnaissance variogram" shows that most variation occurs over distances of 100-300 m. Conversely, in the foothills province variation is concentrated over much shorter distances (right). From Nelson and others (1999). Also see Gomersall and Hinkel (2001). 
(2002, 2003), extended the monitoring and mapping work to incorporate a 13-year spatial time series of ALT in the Kuparuk region, and continued monitoring compilations on an annual basis.

Recent Alaskan investigations under the CALM II program (2004-2009) have focused on monitoring thaw subsidence accompanying thaw penetration into the permafrost underlying the active layer. Shur and others (2005) advanced the concept of the transient layer, an ice-rich layer at the top of permafrost that is subject to freeze/thaw at temporal scales intermediate to those in the active layer and deep permafrost. Monitoring of vertical movements at West Dock and the Sagwon Upland using differential global positioning systems technology (Little and others, 2003) since 2001 indicates that appreciable thaw settlement has occurred over the 6-year period as thaw penetrates into the transient layer. Although no commensurate trend in ALT increase is apparent (fig. C-1), the DGPS data indicate that lengthening of the thawing season is having an appreciable impact on the active layer/upper permafrost system on the North Slope (fig. C-4; Streletskiy and others, 2008).

The Happy Valley site has also been used extensively to investigate topoclimatic influences on ALT. Nearby Costa Hill was used to obtain data on the influence of slope orientation on the active layer (Nelson and others, 1997; also see fig. C-1).

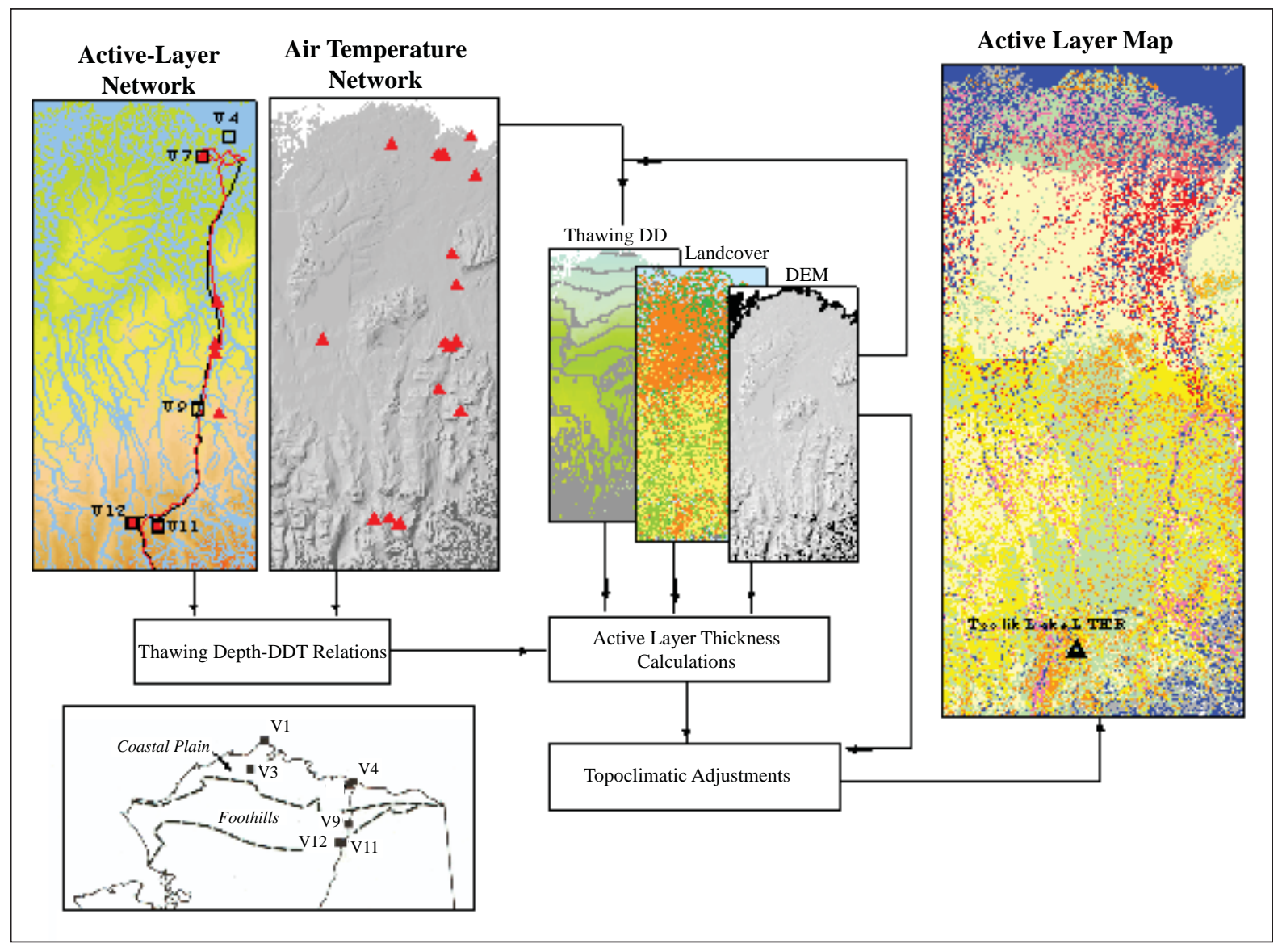

Figure C-3. Schematic of operations involved in empirical modeling of active-layer thickness fields and creating maps of ALT in the Kuparuk region of north-central Alaska. Measurements made at various CALM sites with specific vegetation/soil characteristics are used to create statistical associations with thawing degree-day sums (DDT) obtained from a network of miniature data loggers. Summer lapse rates are used with the DDT data and a digital elevation model (DEM) to create a DDT field for the study area. By merging the DEM, $D D T$, and vegetation data layers and using the empirical relations between DDT and ALT in each vegetation association, a highly detailed map of end-of-season ALT is created (far right). The mapped area contains approximately 28,000 elements, each representing a $300 \times 300 \mathrm{~m}(330 \times 330$ yds) area on the ground surface. Based on Nelson and others (1998). 


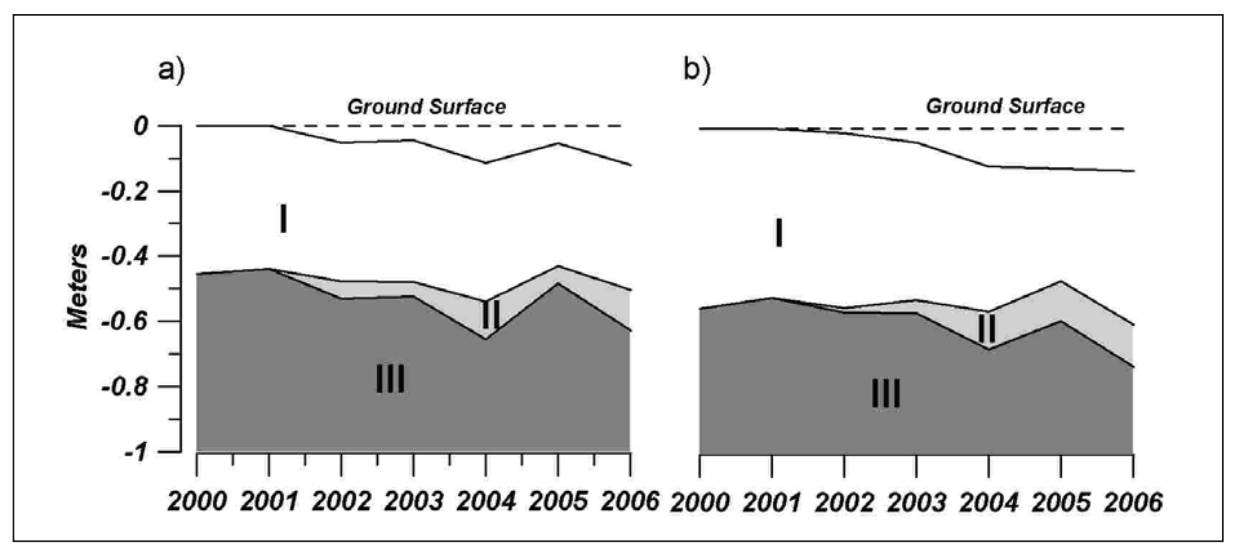

Figure C-4. Annual changes in position of ground surface and active layer thickness (ALT) as measured by steel probe in representative coastal plain (a) and foothills (b) CALM sites. I- ALT as measured by probing; II- ALT, corrected for ground subsidence; IIIpermafrost. From Streletskiy and others (2008).

\section{References}

Brown, J., Hinkel, K.M., and Nelson, F.E., 2000, The Circumpolar Active Layer Monitoring (CALM) program; historical perspectives and initial results: Polar Geography, v. 24, no. 3, p. 165-258.

Gomersall, C. and Hinkel, K.M., 2001, Estimating the variability of active layer thaw depth in two physiographic regions of northern Alaska: Geographical Analysis, v. 33, no. 2, p. 141-155.

Hinkel, K.M., and Nelson, F.E., 2003, Spatial and temporal patterns of active layer thickness at CALM sites in northern Alaska, 1995-2000: Journal of Geophysical Research-Atmospheres, v. 108, no. D2, 15 p.

Klene, A.E., Nelson, F.E., and Shiklomanov, N.I., 2001a, The n-factor as a tool in geocryological mapping; seasonal thaw in the Kuparuk River basin, Alaska: Physical Geography, v. 22, no. 6, p. 449-466.

Klene, A.E., Nelson, F.E., Shiklomanov, N.I., and Hinkel, K.M., 2001b, The n-factor in natural landscapes; variability of air and soil-surface temperatures, Kuparuk River basin, Alaska: Arctic, Antarctic, and Alpine Research, v. 33, no. 2, p. 140-148.

Little, J., Sandall, H., Walegur, M., and Nelson, F.E., 2003, Application of differential GPS to monitor frost heave and thaw settlement in tundra environments: Permafrost and Periglacial Processes, v. 14, no. 4, p. 349-357.

Muller, S.V., Walker, D.A., Nelson, F.E., Auerbach, N.A., Bockheim, J., Guyer, S., and Sherba, D., 1998, Accuracy assessment of a land-cover map of the Kuparuk River basin, Alaska; considerations for remote regions: Photogrammetric Engineering and Remote Sensing, v. 68, no. 6, p. 619-628.

Nelson, F.E., Shiklomanov, N.I., Mueller, G.R., Hinkel, K.M., Walker, D.A., and Bockheim, J.G., 1997, Estimating active-layer thickness over a large region; Kuparuk River basin, Alaska, USA: Arctic and Alpine Research, v. 29, no. 4, p. 367-378.

Nelson, F.E., Shiklomanov, N.I., and Mueller, G.R., 1999, Variability of active-layer thickness at multiple spatial scales, north-central Alaska, USA: Arctic, Antarctic, and Alpine Research, v. 31, no. 2, p. 158-165.

Overduin, P.P., and Hinzman, L.D., 2002, Monitoring active layer depth at Council and Kougarok, Seward Peninsula, Alaska: Presentation at First Circumpolar Active Layer Monitoring Workshop, November 2002, Lewes, DE.

Shiklomanov, N.I., and Nelson, F.E., 2002, Active-layer mapping at regional scales; a 13-year spatial time series for the Kuparuk region, north-central Alaska: Permafrost and Periglacial Processes, v. 13, no. 3, p. 219-230.

Shiklomanov, N.I., and Nelson, F.E., 2003, Climatic variability in the Kuparuk region, north-central Alaska; optimizing spatial and temporal interpolation in a sparse observation network: Arctic, v. 56, p. 136-146.

Shur, Y., Hinkel, K.M., and Nelson, F.E., 2005, The transient layer; implications for geocryology and global-change science: Permafrost and Periglacial Processes, v. 16, no. 1, p. 5-17.

Streletskiy, D.A., Shiklomanov, N.I., Nelson, F.E., and Klene, A.E., 2008, Long-term active layer and ground surface temperature trends; 13 years of observations at Alaskan CALM sites: Proceedings of the Ninth International Conference on Permafrost, p. 1,727-1,732.

Weller, G., Chapin, F.S. III, Everett, K.R., Hobbie, J.E., Kane, D.L., Oechel, W.C., Ping, C.L., Reeburgh, W.S., Walker, D.A., and Walsh, J., 1995, The Arctic Flux Study; A regional view of trace gas release: Journal of Biogeography, v. 22, p. 365-374. 


\title{
Appendix D \\ Annotated Agenda for the North Slope Oil Fields Tour as Part of the Permafrost Conference June 27, 2008
}

\author{
Bill Streever, streevbj@bp.com
}

This agenda provides an overview of the BP-operated North Slope oilfields with an emphasis on ecological and wildlife issues. Issues of interest include:

- a variety of restoration sites;

- tundra lakes;

- indirect impacts of gravel (i.e., impoundments and the effect of dust);

- various industry facilities;

- old and new technologies (i.e., the move to smaller pads through closer spacing of wells and downhole injection of wastes);

- bird plots monitored by the Wildlife Conservation Society;

- pingos and polygonized ground; and

- issues associated with offshore development, including marine mammals and sound issues.

Wildlife (possibly caribou, foxes, various birds and, if we are lucky, brown bears and musk oxen) will be seen during the day. Bring binoculars and cameras and wear waterproof boots, especially for the MS3 Trenching Trials Site.

Drive to MS3 Trenching Trials Site: Deadhorse is an oilfield service community with no full-time population. Companies that provide contract services to the major oil companies are based in Deadhorse. Various kinds of specialized equipment can be seen along the road. Look for winter travel vehicles (snow machines, tracked vehicles, rollagons) and drilling equipment (drill rigs and also drill string $-10 \mathrm{~m}$ lengths of threaded pipe about $10 \mathrm{~cm}$ in diameter).

MS3 Trenching Trials Site (figs. D-1, D-2; tables 1, 2): 1 mile south of Deadhorse. This site is one of three sites where trenches were dug to test trenching equipment that might eventually be used for a gas pipeline construction project. This stop requires a short walk across potentially wet tundra (high boots recommended). The trenches are in rows. Total trench length is about $5 \mathrm{~km}$. All trenches were backfilled with frozen material and capped to $\sim 1 \mathrm{~m}$ above grade. Uneven collapsing left some trenches below grade and others with caps up to $\sim 30 \mathrm{~cm}$ above grade. In addition, some trenches captured ice wedges and triggered thermokarst between polygons. Additional backfill was hauled to the site in winter 2007-08. All trenches have been seeded with Puccinellia borealis and fertilized. Monitoring is required for at least 10 years after construction, and all trench caps must have $>10 \%$ plant cover (excluding seeded grasses). No trench caps can be below grade for a length of $>10 \mathrm{~m}$.

Additional topics of discussion for this site: Gravel mine, Sag River, caribou movements (caribou trails, riparian corridors).

Drive to GC2 Spill Site: Travel through oilfield security check station (west checkpoint) and progress to GC2 Spill Site. Pass back through Deadhorse and enter the oilfields managed by BP. Along the way, on the west side of the road, prevailing winds (from the east) carry road dust. Note that a portion of the road is chipsealed (paved), which prevents dusting and decreases road maintenance requirements while also offering some protection to the tundra. Pass Pump Station 1 (the beginning of TAPS) and other oil field infrastructure.

GC2 Spill Site (figs. D-3, D-4): In March 2006, oil spilled from a corroded pipeline onto the tundra, affecting nearly 1 ha (2.1 acres) of tundra. Oil was removed and soil excavated. Overburden was placed on the site to replace excavated soil, and then topped with vegetated tundra mat salvaged from a mine site. The site was fertilized in summer 2006. In summer 2007, a small area immediately beneath the pipeline was sodded 
using a method practiced by North Slope Inupiat (for construction of ice cellar roofs and sod houses). For safety reasons, do not cross beneath the pipelines to the site. A catwalk may provide limited access across the top of the pipes. Please do not walk on the rehabilitation site.

Additional topics of discussion for this site: Caribou crossings (pipeline height and road separation) (fig. D-5), bird strikes and power lines (figs. D-6, D-7).

Annex 3 Restoration Site (fig. D-8): Annex 3 previously supported a camp for project personnel. In 1999, gravel was removed. Additional gravel was removed in 2000. In 2007, a culvert was installed to remove trapped water. Willow has been sprigged on a portion of the site and fertilizer has been applied. The site will be monitored for 10 years and must achieve performance standards that include $>10 \%$ plant cover (excluding seeded grasses) and support of at least five species of native plants. Note that this site represents the third major type of rehabilitation work currently underway on the North Slope- the other two are tundra disturbances from trenching (MS3 Site) and disturbance related to oil spill cleanup.

Additional topics of discussion for this site: Landscape level restoration, seeding, the restoration database.

Big Lake (fig. D-9): Big Lake is the water source for the Base Operations Center (BOC). Explanation of water use issues on the North Slope and the dynamics of North Slope lakes, with a focus on discussion of winter water removal for construction of ice roads (fig. D-10) and possible future use of low salinity lake water for enhanced recovery.

Additional topics of discussion for this site: Rivers (figs. D-11, D-12), Badami weir (fig. D-13).

Base of Operations Center (BOC): Lunch at Base of Operations Center. The BOC provides office and housing space. It also contains a medical facility and a firehouse. During lunch at the BOC, observe how oilfield workers live (and eat) during their shifts. Most workers do two-week shifts (two on, two off), but some do one-week shifts, and others come up on an as-needed basis for a few days up to several months.

Biocomplexity Study Site: Observe work done at Biocomplexity Study Site related to frost heaves, active layer thickness, and biocomplexity (figs. D-14, D-15).

Additional topics of discussion for this site: WCS bird study (fig. D-16).

Seawater Treatment Plant: Search for ringed seals on the sea ice. Look for remains of ice road.

Additional topics of discussion for this site (figs. D-17, D-18, D-19): Marine mammal and sound issues (fig. D-17), polar bear issues (fig. D-18).

Prudhoe Mound Pingo: Travel to Prudhoe Mound Pingo near LPC turnoff, with a slight detour to view the gravel mine, landfill, and power line trench just before the landfill. Observe pingo vegetation patterns and related issues.

Additional topics of discussion for this site: Humans and wildlife on and in pingos (figs. D-20, D-21).

Depart from Deadhorse airport

\section{MS3 Trenching site}

- Trenched February 13-27, 2002, to test trenching gear.

- Does not contain active pipe.

- Backfilled with gravel and overburden (and snow and ice). 

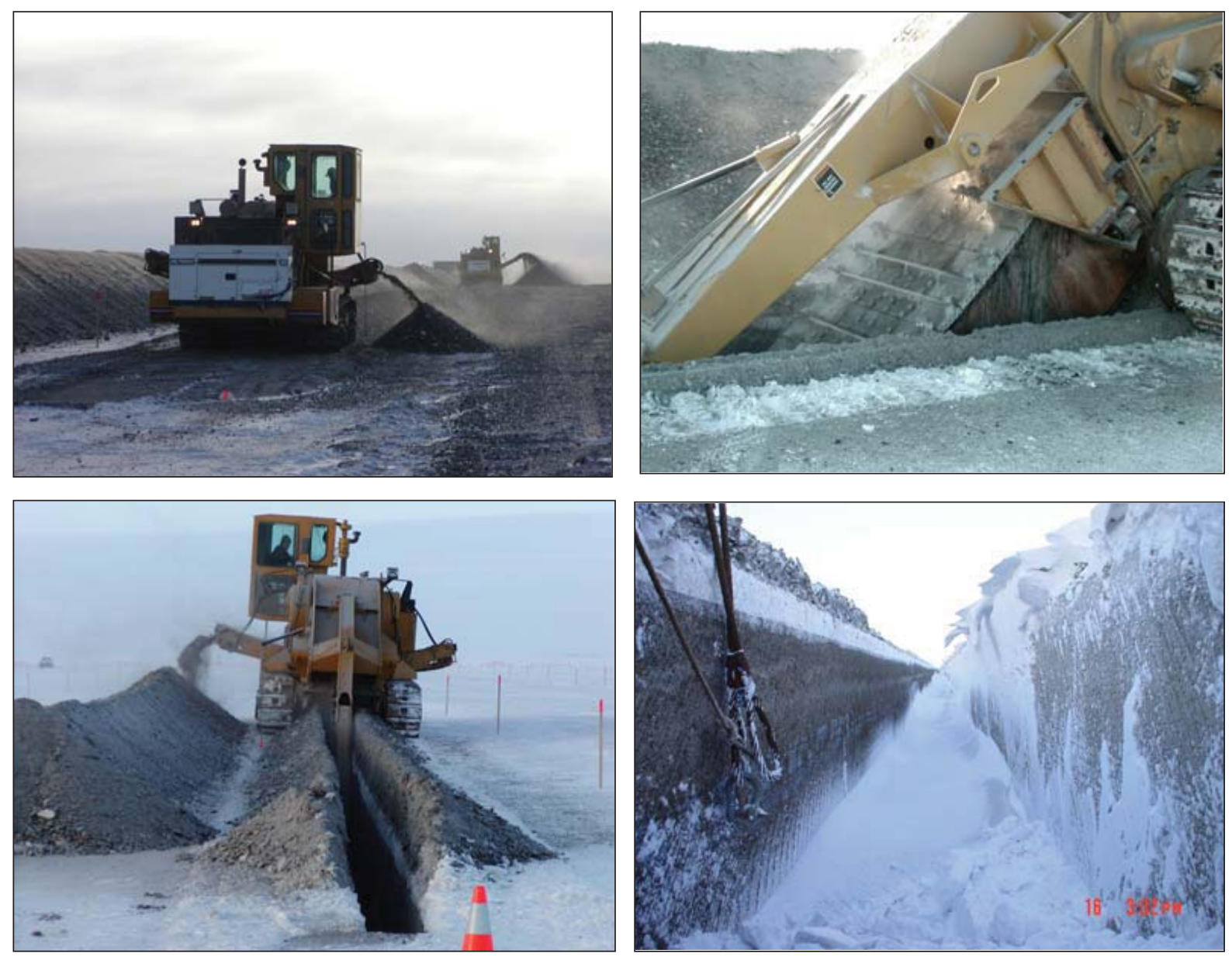

Figure D-1. 
Table 1. Goals, objectives, performance standards, and monitoring methods for rehabilitation of MS3 Trenching Trials Test Site, North Slope, Alaska (based on the revised draft rehabilitation plan dated July 18, 2002, supplementary rehabilitation plan dated March 3, 2005, and rehabilitation plan dated May 10, 2007).

Goal Promote recovery of native tundra vegetation on the backfilled trenches (and explosives testing area).

Objectives Elimination of linear depressions and establishment of substantial plant cover by native species (excluding grass cultivars).

Performance Standards Year 10 (2012):

1. No continuous linear flooded depressions greater than $33 \mathrm{ft}$ long with water depths that impede vegetation establishment,

2 . $\geq 15 \%$ live cover of vascular plants (excluding seeded grasses), and

3 . $\geq 5$ indigenous species with $>0.2 \%$ cover by each species.

Monitoring Methods

Topography: Qualitative searches for extended water-filled depressions that appear to be impeding revegetation; photographic documentation; and elevation measurements at least every $10 \mathrm{ft}$ along trenches.

Vegetation cover: Use BP's standard method for measuring plant cover except that the laser-assisted pint sampling (LAPS) device will be used to sample vegetation. Overall cover will be measured as an average across all trenches. Number of species and per species cover requirement will be measured cumulatively across the site. 


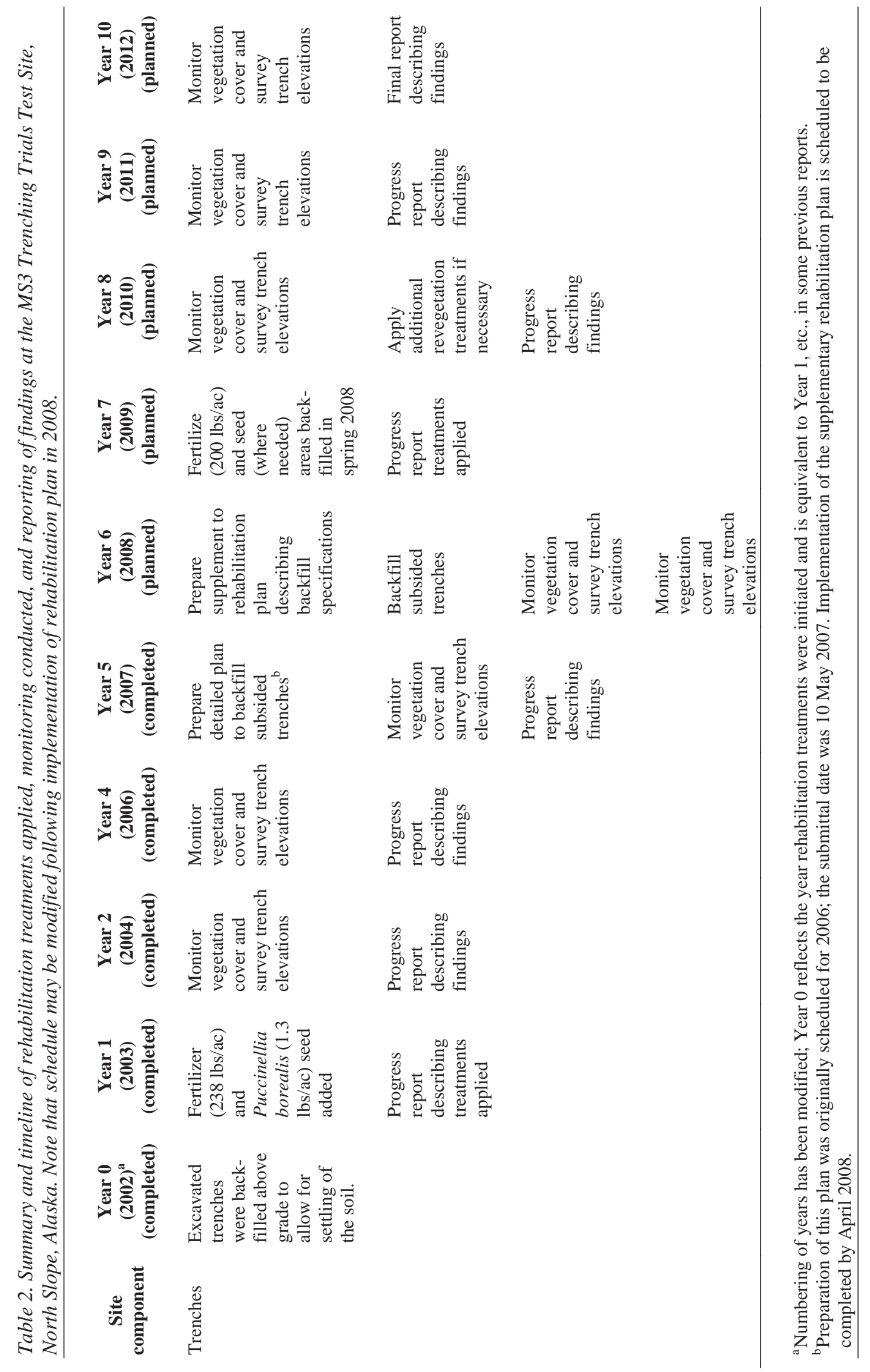




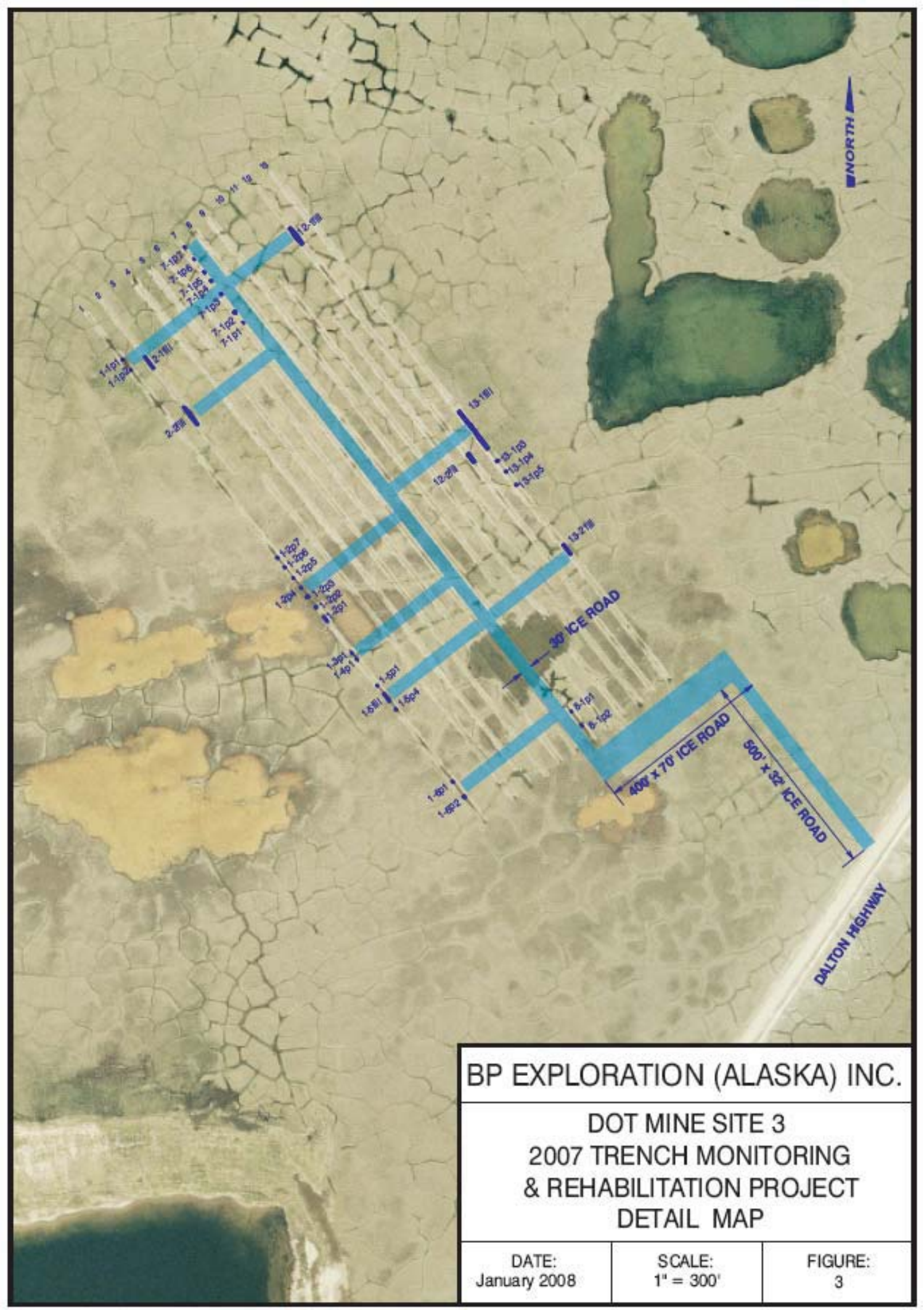

Figure D-2. 


\section{Rehabilitation Briefing Sheet \\ GC-2 Spill Site \\ 11 June 2008}

Background: An oil spill was discovered on 2 March 2006. It covered approximately 2.1 acres ( $<1$ ha) of moist sedge-shrub tundra (one of the North Slope's typical tundra plant communities). The site was excavated to varying depth, depending on contamination and ground ice, but reaching depths as great as $6 \mathrm{ft}(1.8 \mathrm{~m})$. Clean fill containing live plant matter was imported to the site and placed in a manner to approximate the original site elevations. Use of tundra soil with live plant matter is not a common practice, but in this case it is expected to promote rapid return of the sedge-shrub tundra community. The fill was retrieved from a stock pile at the Put 23 mine site.

Summer 2006: Throughout the growing season, wildlife hazing was maintained at the site. In addition, an effort was made to manually reposition blocks of fill so that living leaves and shoots faced upwards (fig. D-3). An irrigation system (white pipes in fig. D-3) was set up to maintain favorable moisture conditions on an as-needed basis. Four hundred pounds per acre of fertilizer (20-20-10 NPK) was spread. Vegetation and elevation were monitored. Mean live vascular cover was $\sim 2.7 \%$, virtually all of which was comprised of plants surviving in the manually positioned blocks of fill. Elevations were about 2 inches higher than those of the surrounding tundra but were expected to subside slightly over time.

Summer 2007: The irrigation system was re-established. As agreed upon during spill response, ABR and LCMF personnel transplanted about 1,000 sq. ft (0.023 acres) of tundra sod from the Put 23 mine site to an area immediately underneath the pipe racks at the spill site (fig. D-4). Although the sod appears to create an "instant tundra community” the process costs about $\$ 800,000$ per acre using currently available methods (i.e., manual labor). Vegetation and elevation were monitored. Outside of the sodded area, vascular plant cover was $\sim 1.6 \%$. It is important to remember that most growth is below ground

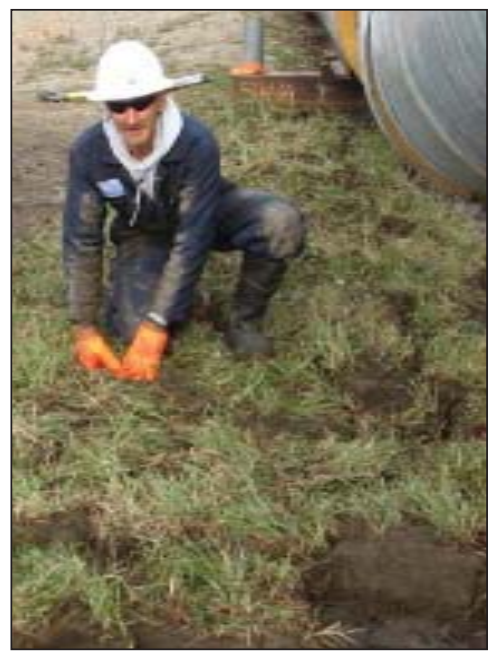
as the roots become well established. Also, it is important to note that $\sim 2 \%$ cover after two

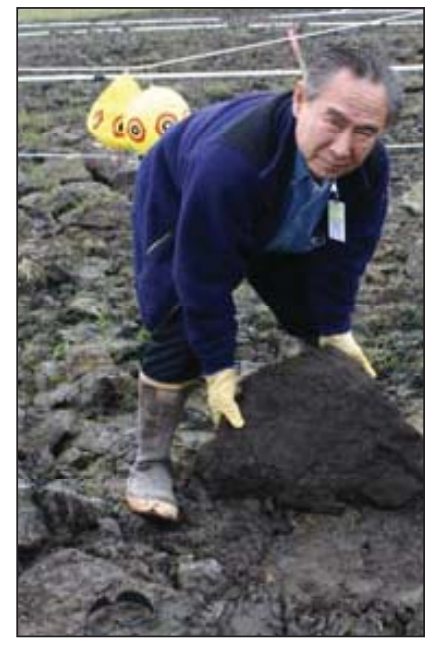

Figure D-3. growing seasons exceeds that found at typical rehabilitation sites on the North Slope. Average elevation had not changed since 2006. Thaw depth was $2.8 \mathrm{~cm}$ less than in 2006.

Progress Towards Performance Standards: Performance standards require $10 \%$ vascular plant cover by the end of 2009. Additional sodding will be considered if 2008 monitoring does not suggest an increase in cover. For the sake of comparison, cover on undisturbed tundra would range from 50-80\% (using cover estimation methods similar to those used at GC-2). Because plant cover increased rapidly after root establishment, it remains reasonable to believe that this performance standard will be achieved. Overall, in comparison to other approaches to tundra restoration used on the North Slope, the methods used at the GC-2 spill site promise to lead to a rapid return to a community similar to that found on the site prior to the spill.

Figure D-4. 

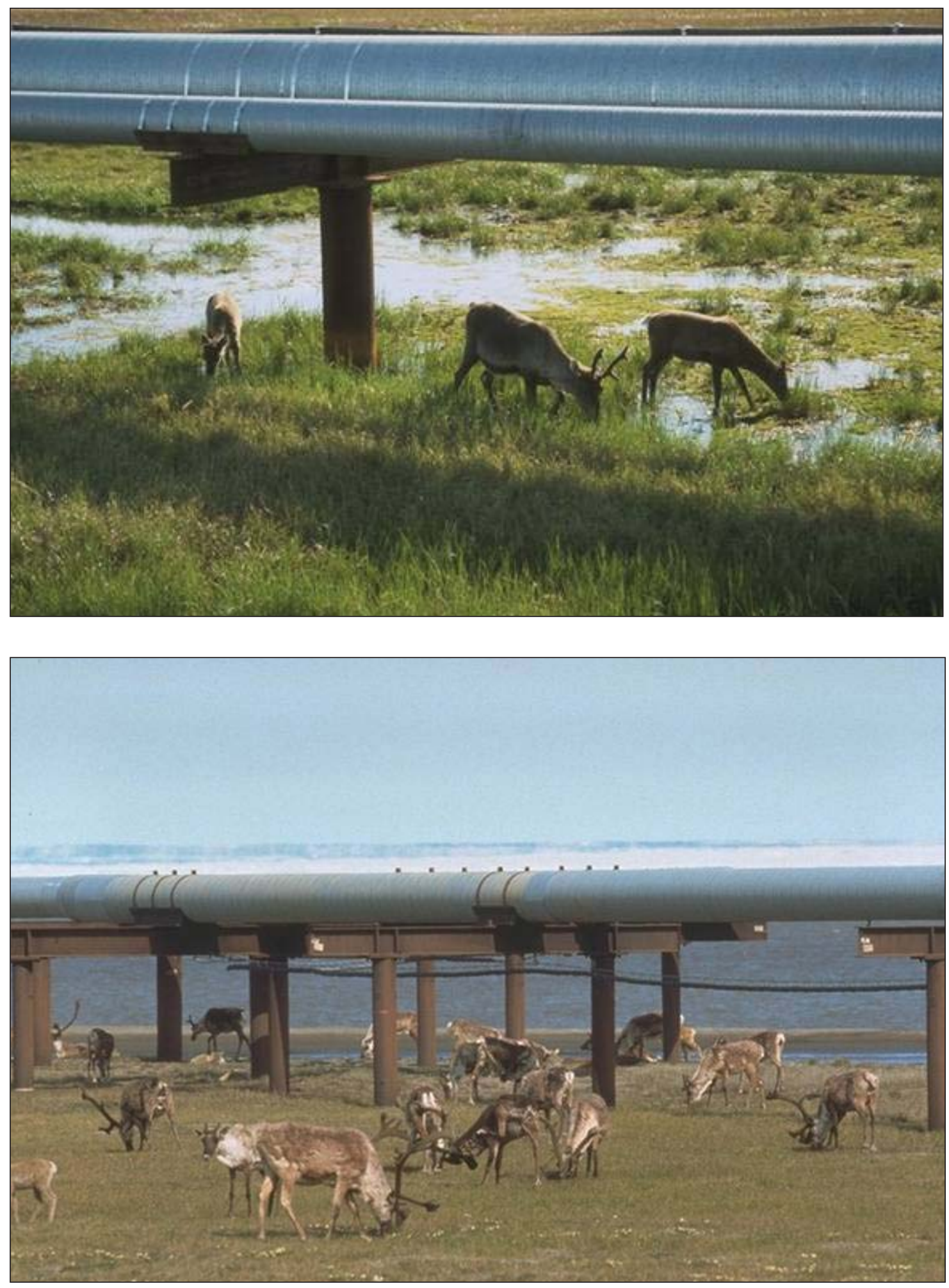

Figure D-5. Caribou and pipelines: Minimum height is 7 feet and separation from roads is 500 feet. 

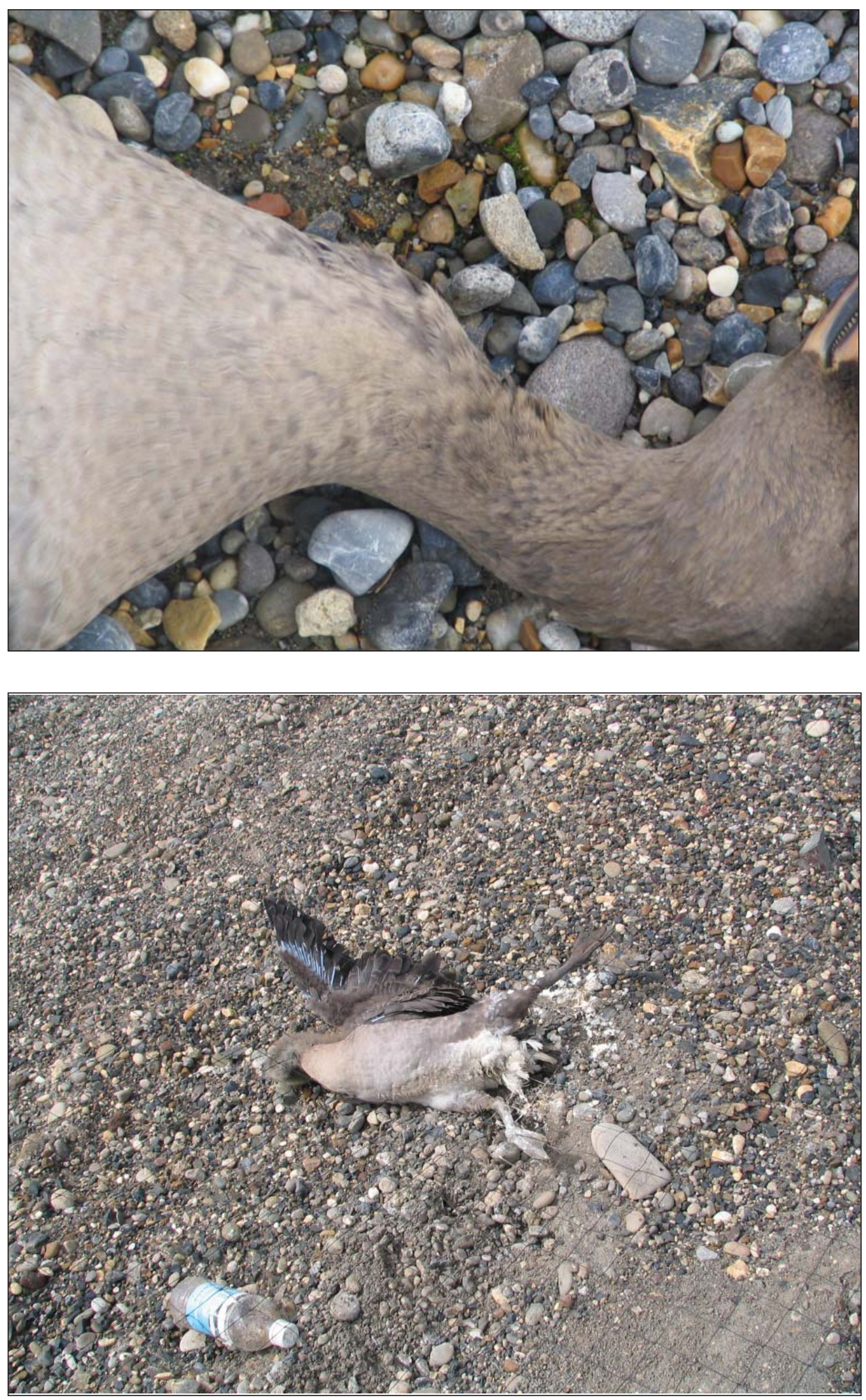

Figure D-6. Bird strikes: Power lines, trucks, buildings, nets. 

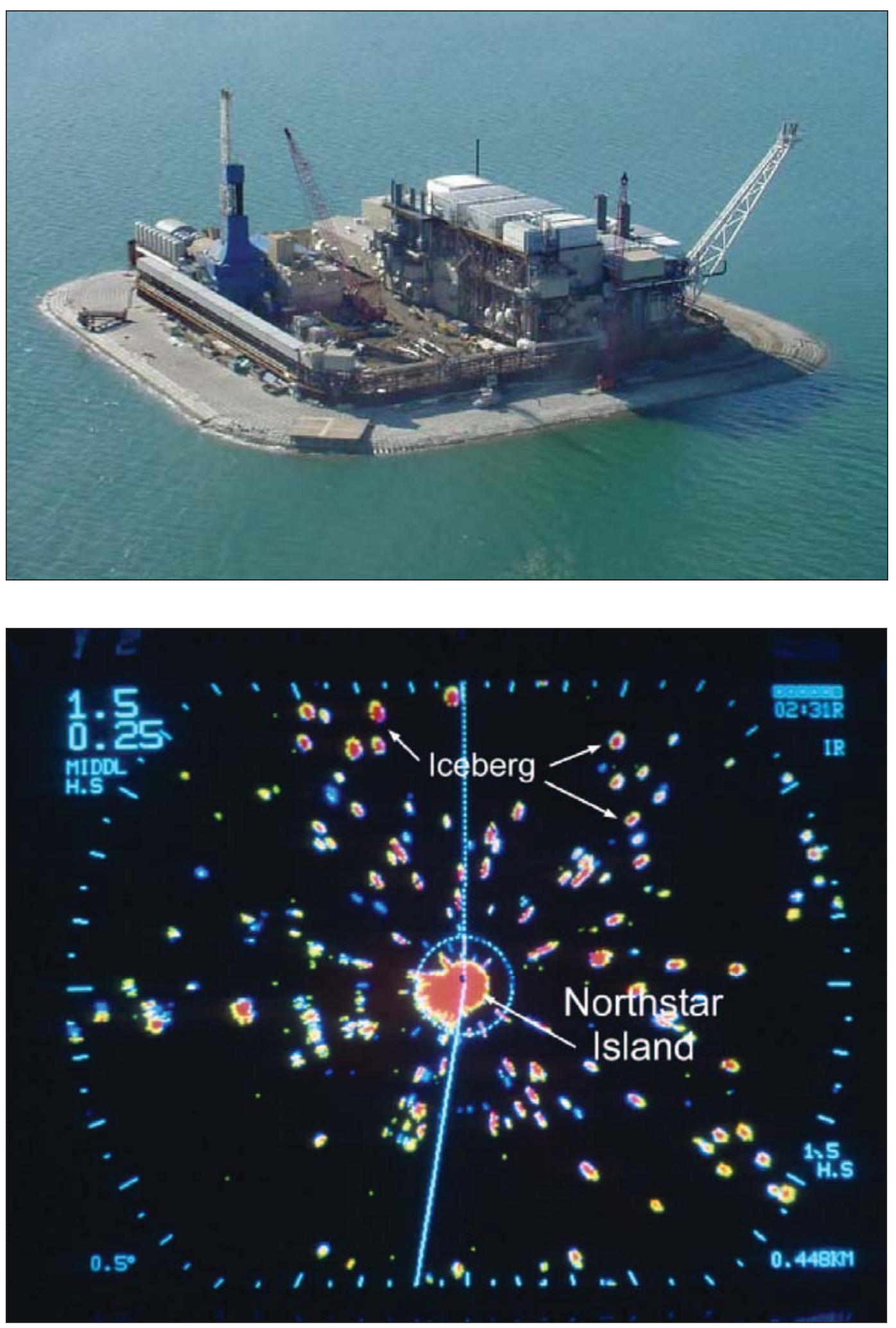

Figure D-7. Bird strikes: Avian radar study and bird deflection lighting. 


\section{Annex 3 Restoration Site}

- Annex 3 previously supported a personnel camp.

- In 1999, gravel was removed. Additional gravel was removed in 2000.

- In 2007, a culvert was installed to remove trapped water.

- Willow has been sprigged on a portion of the site.

- Fertilizer has been applied.

- The site will be monitored for 10 years and must achieve performance standards that include $>10 \%$ plant cover (excluding seeded grasses) and support of at least five species of native plants.

- Other gravel removal sites illustrated below (fig. D-8).
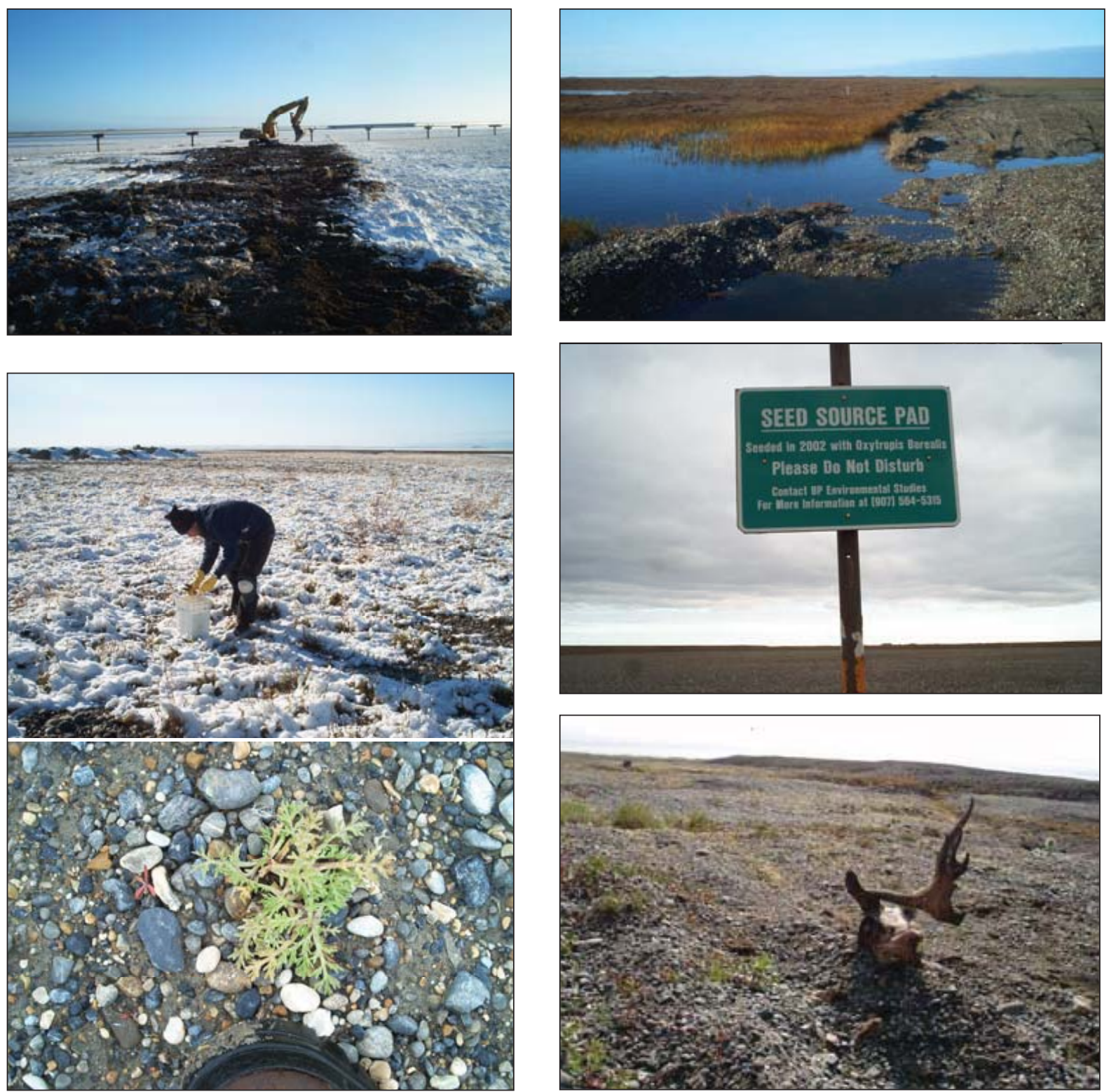

Figure D-8. 


\section{Big Lake}

\section{Overview of Tundra Lakes on the North Slope:}

- Moulton classified lakes into three types based on natural history: (1) deflation lakes, which form when dunes become revegetated and the basin between the dunes fills with water; (2) oxbow lakes, which are of intermediate depth and formed from abandoned river channels; and (3) thaw lakes, which are the most common lakes on the North Slope, are shallowest, and are formed as the ground subsides and icerich permafrost melts.

- $50-75 \%$ of the Arctic Coastal Plain is covered by lakes and ponds or thaw lake basins.

- Dissolved oxygen is substantially reduced in natural lakes, under ice, in winter. In summer, the wind distributes the oxygen derived from the atmosphere throughout the water column and oxygen levels are at saturation or super-saturation.

- Man-made reservoirs are also present in the oilfields. These reservoirs are some of the deepest "lakes" on the North Slope, ranging from approximately 20 to $50 \mathrm{ft}$ (6-15 m) deep.

- Big Lake is the main water source for the BOC. It is permitted for just over 34 million gallons (129 million liters) a year. In 2007, BP used just over 22 million gallons (84 million liters).

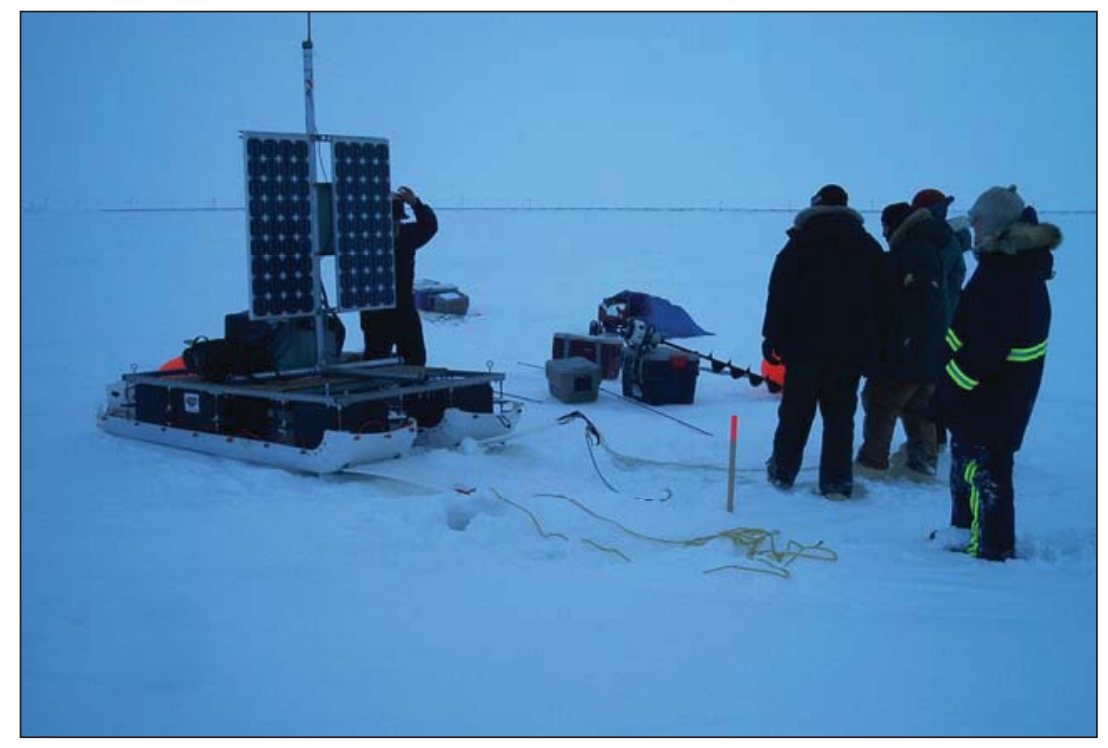

Figure D-9. Measuring limnological variables. 


\section{Ice Roads}

- A 1-mile-long by 40-foot-wide by 6-inch-thick ice road needs 1-1.5 million gallons of water, according to some sources.
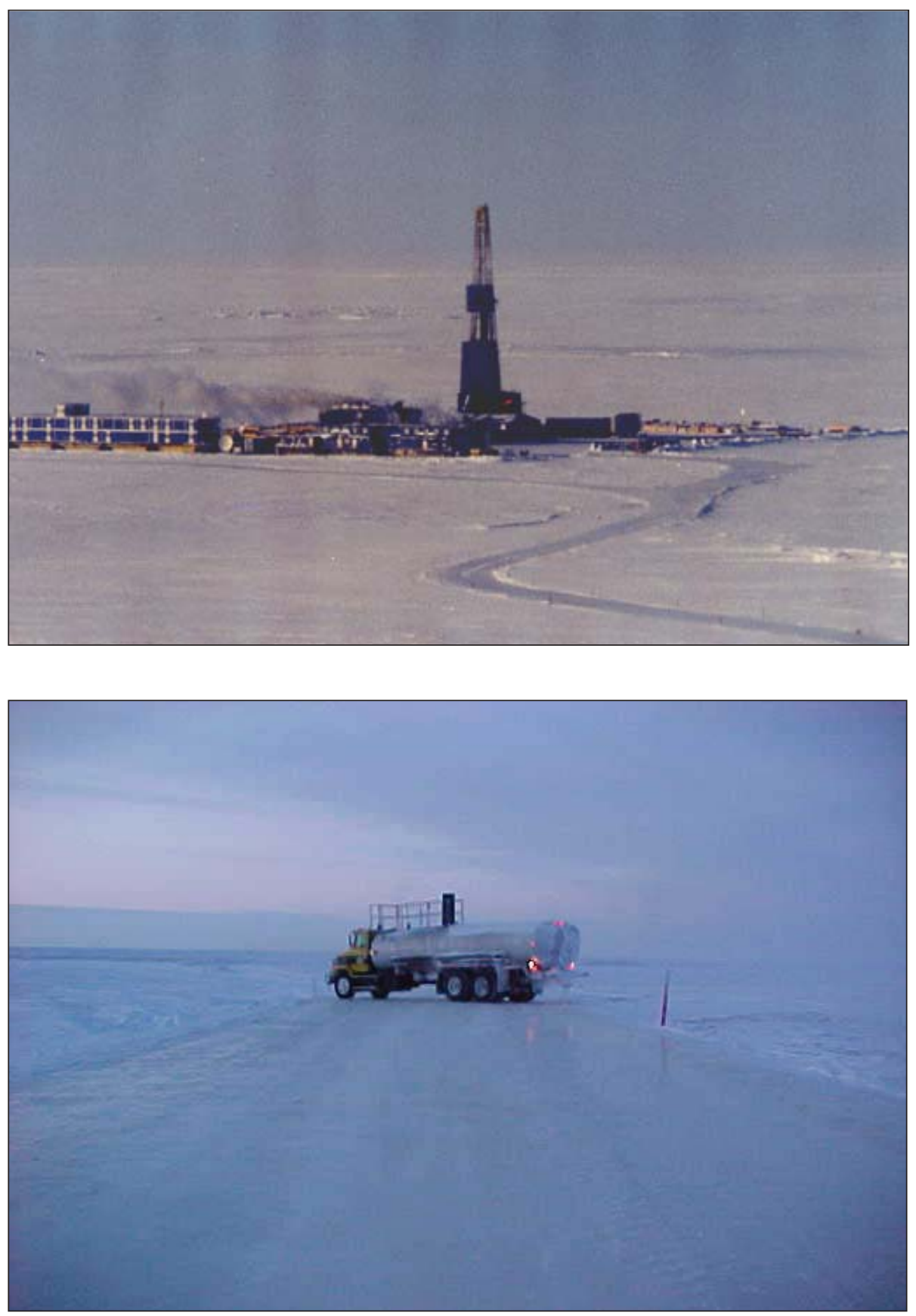

Figure D-10. Ice pad and ice road. 


\section{Rivers}

- Three major rivers flow through the Prudhoe Bay oilfields heading north to the Beaufort Sea: The Sagavanirktok, Putuligayuk, and Kuparuk rivers.

- The Sagavanirktok River, commonly referred to as the Sag River, is a fairly narrow river from the Brooks Range foothills to the coastal plain. Its headwaters, which are mountain, glacier-fed, and spring streams, are located in the eastern portion of the Brooks Range. The Sagavanirktok River has been gaged by the USGS near Pump Station 3 since 1982.

- The Putuligayuk, commonly referred to as the Put River, is a smaller river located between the Kuparuk and Sagavanirktok river watersheds. The summer base flow conditions for the Putuligayuk River are very low with only one peak flooding event occurring sometime between the last week in May to the middle of June.

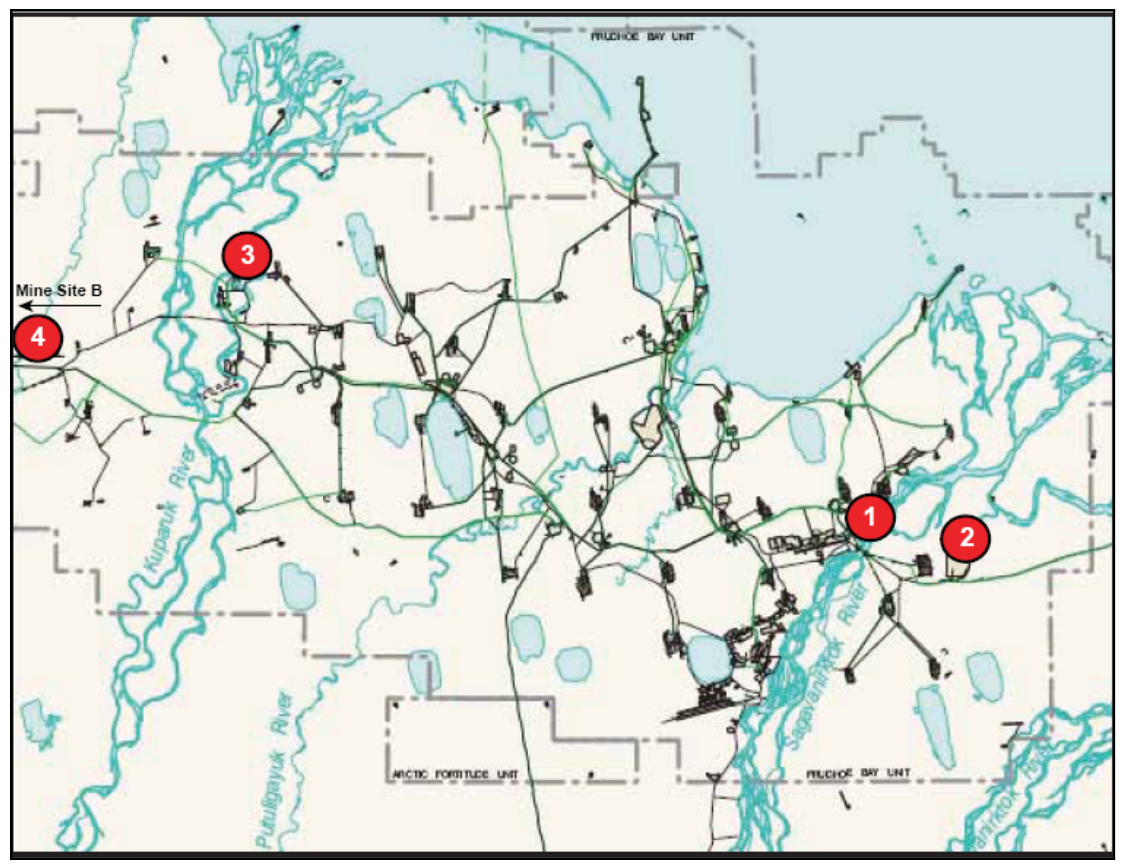

Figure D-11. Map showing the Sagavanirktok, Putuligayuk, and Kuparuk rivers in relation to the Prudhoe Bay oilfields. (1) is the Webster Reservoir; (2) is the Duck Island Mine Site; (3) is the Kuparuk Deadarm Reservoirs; and (4) is an arrow pointing to Mine Site $B$. 


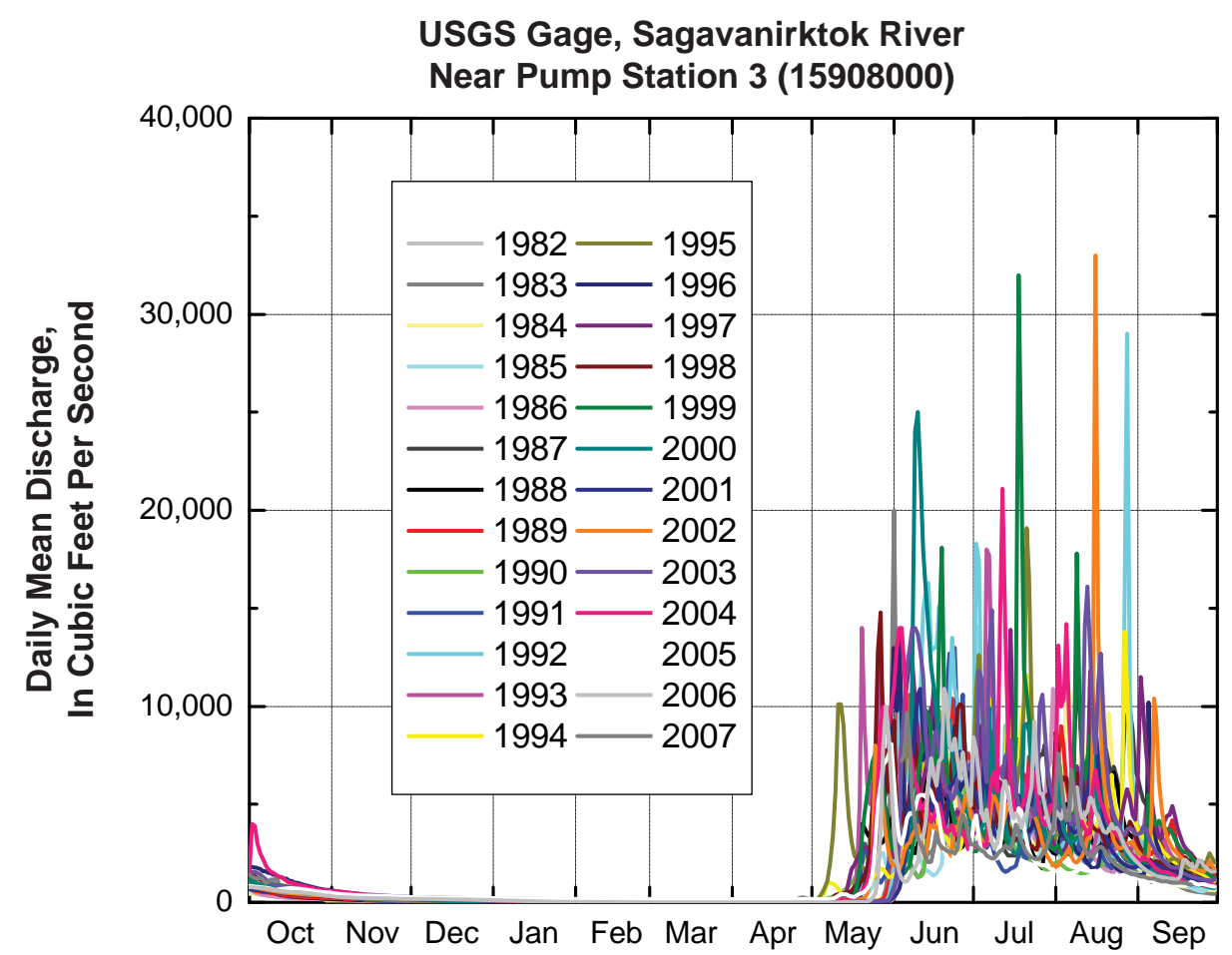

Figure D-12a. Discharge hydrographs by year for the Sagavanirktok River near Pump Station 3.

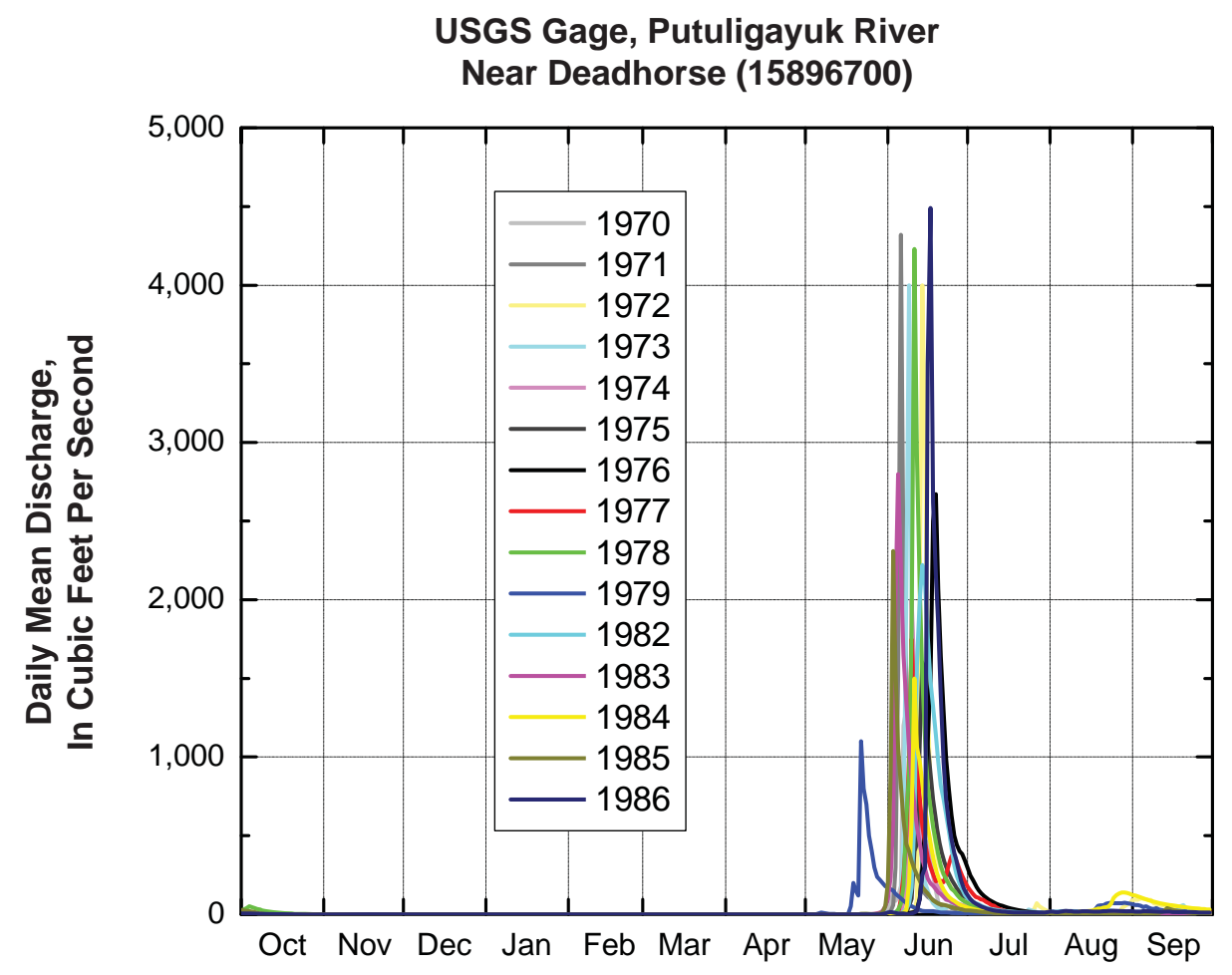

Figure D-12b. Discharge hydrographs by year for the Putuligayuk River near Prudhoe Bay, upstream of Spine Road. Gage data is not available for 1980 and 1981. 


\section{Badami Weir: Pipeline crossing under the Sag River}

- Pipeline drilled under the Sag River

- Thermokarst combined with hydraulic erosion joins Oxbow Lake to river

- Weir installed

- Banks of discharge channel erode

- Thermokarsting at edges of weir?

- Note caribou tracks (riparian corridors)
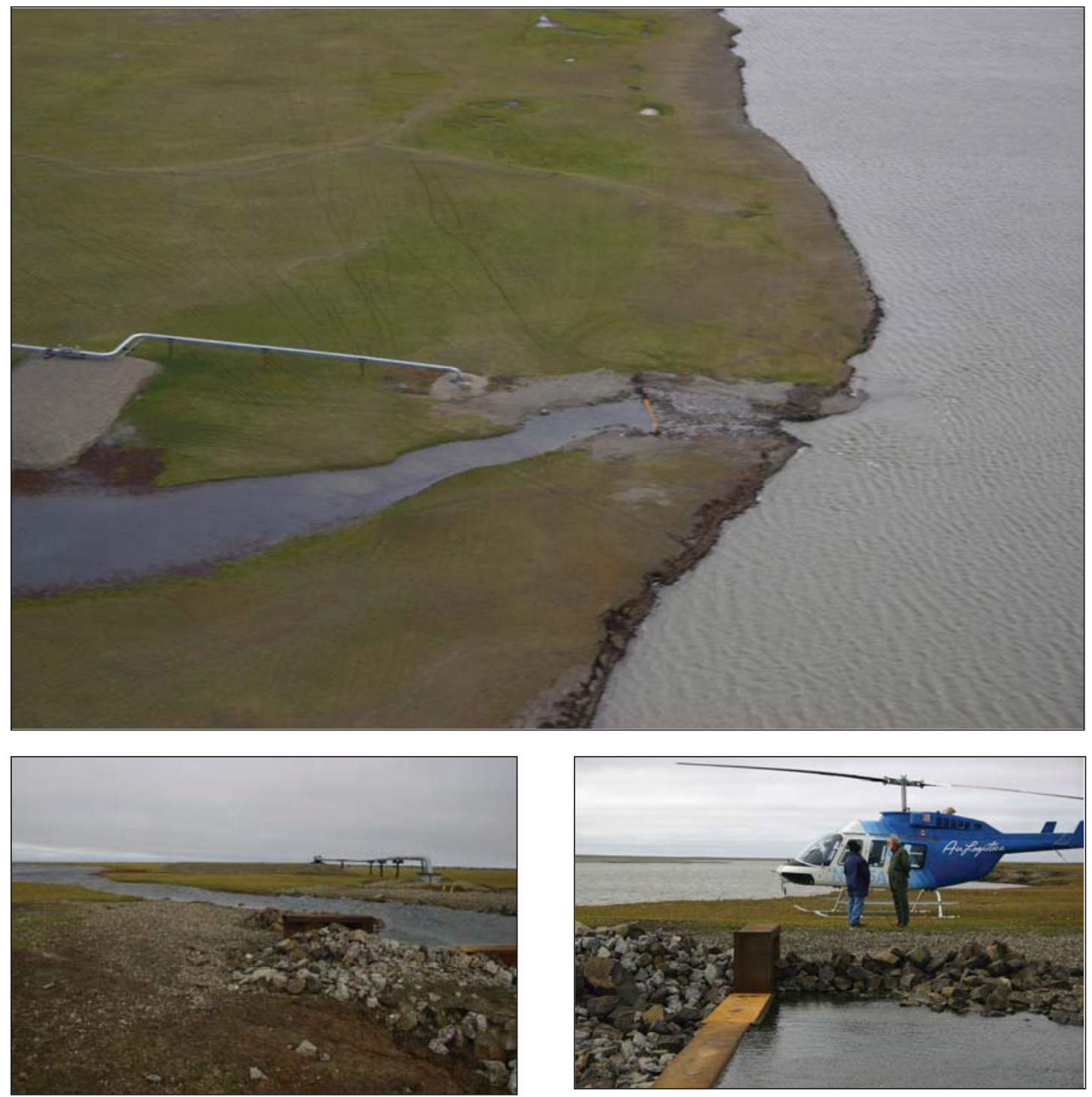

Figure D-13. 


\section{Biocomplexity Study Site}

- The Biocomplexity Study Site has hosted a number of studies over a long period.

- Measurements of active layer thickness and frost heave

- Measurements of vegetation communities and snow cover

- Weather data
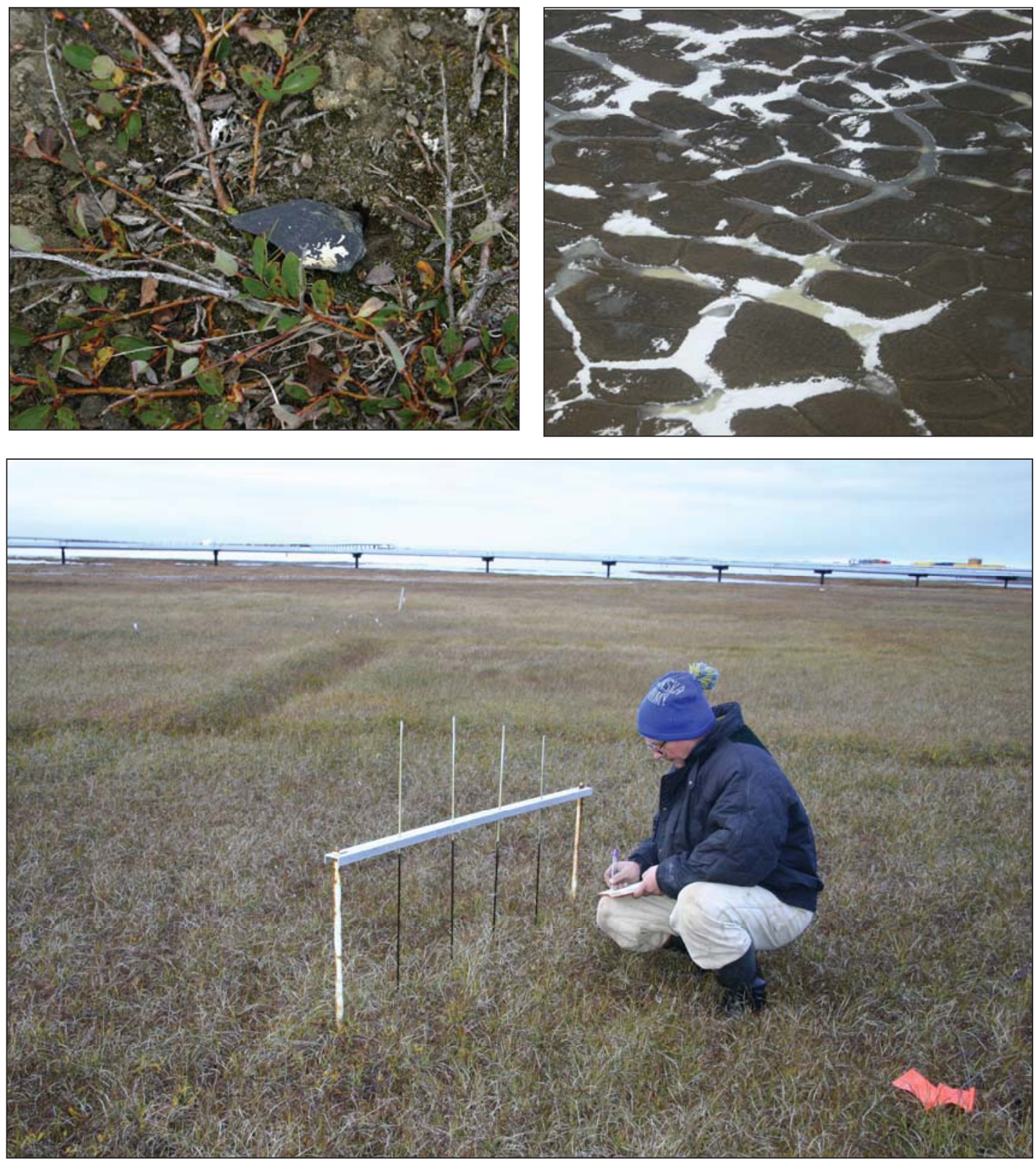

Figure D-14. 


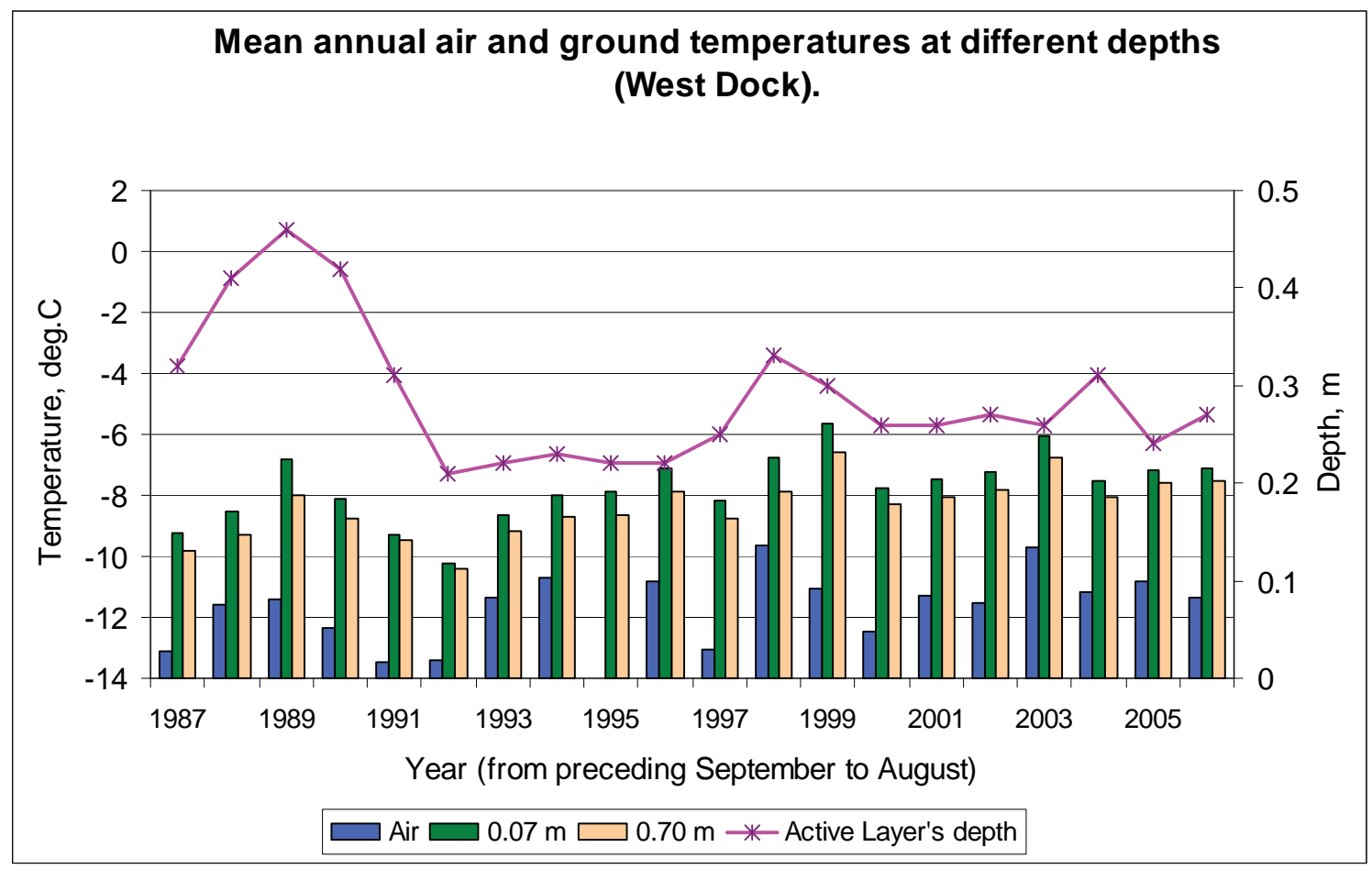

Figure D-15. 

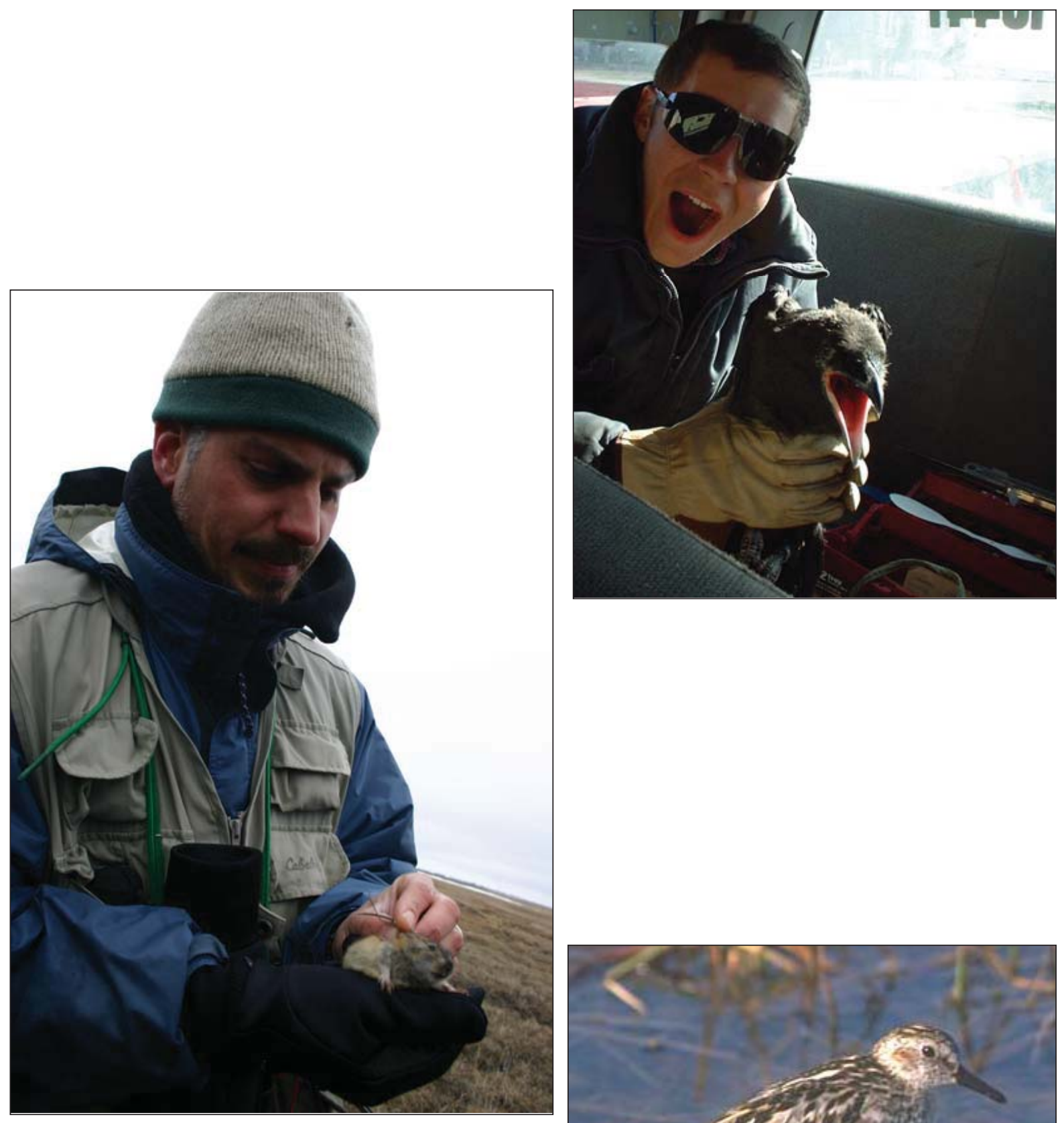

Figure D-16. WCS bird studies

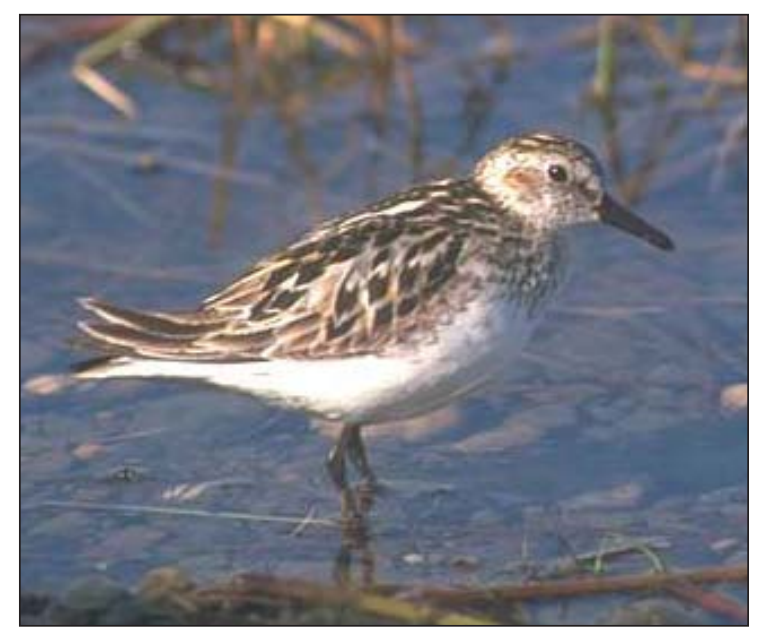




\section{Seawater Treatment Plant (STP)}

- Treats 900,000 barrels per day (bpd)

- "Replaces" fluids removed from the downhole

- Removes suspended solids and oxygen
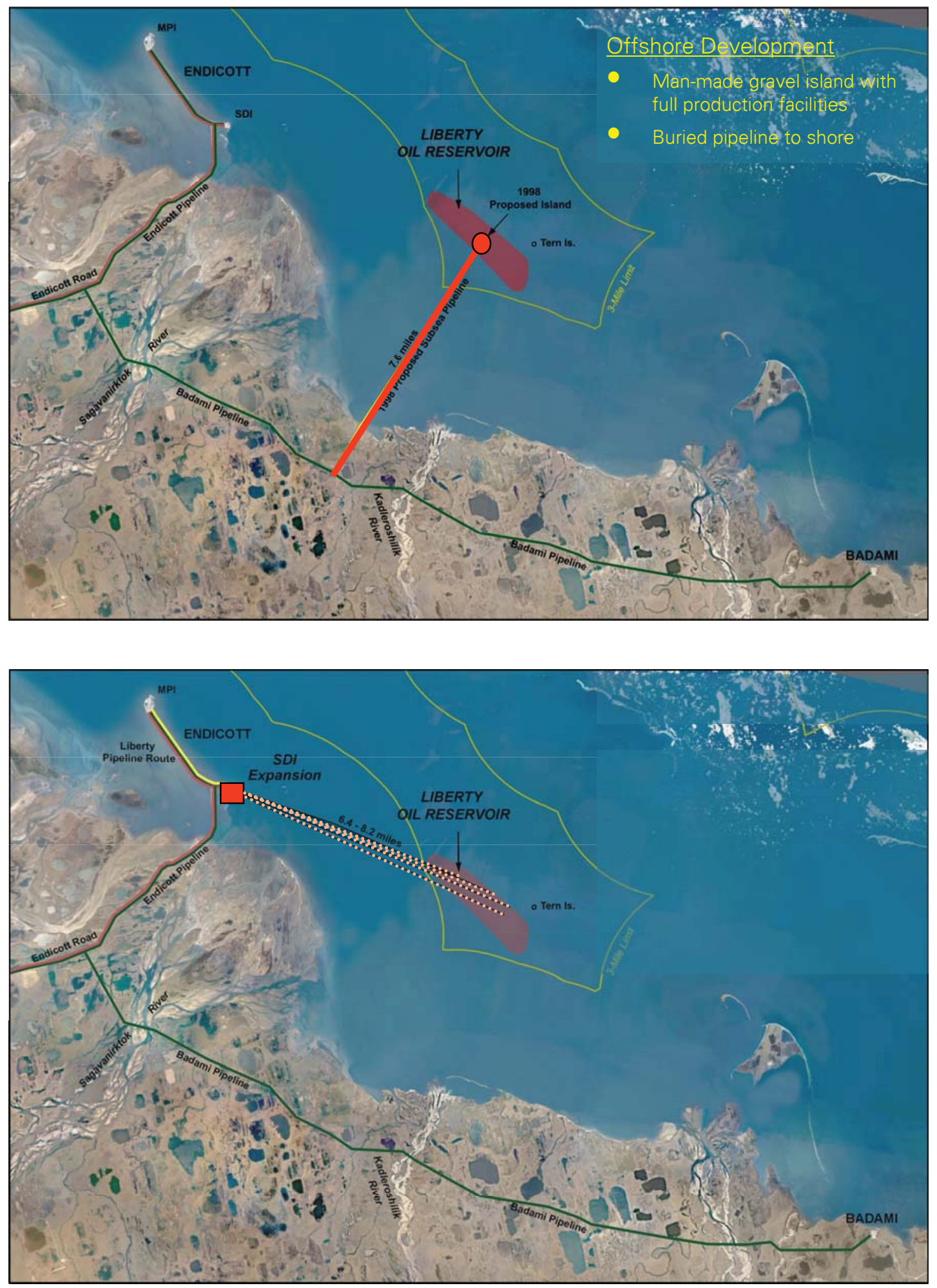

Figure D-17. Liberty Project (to be built east of STP). 


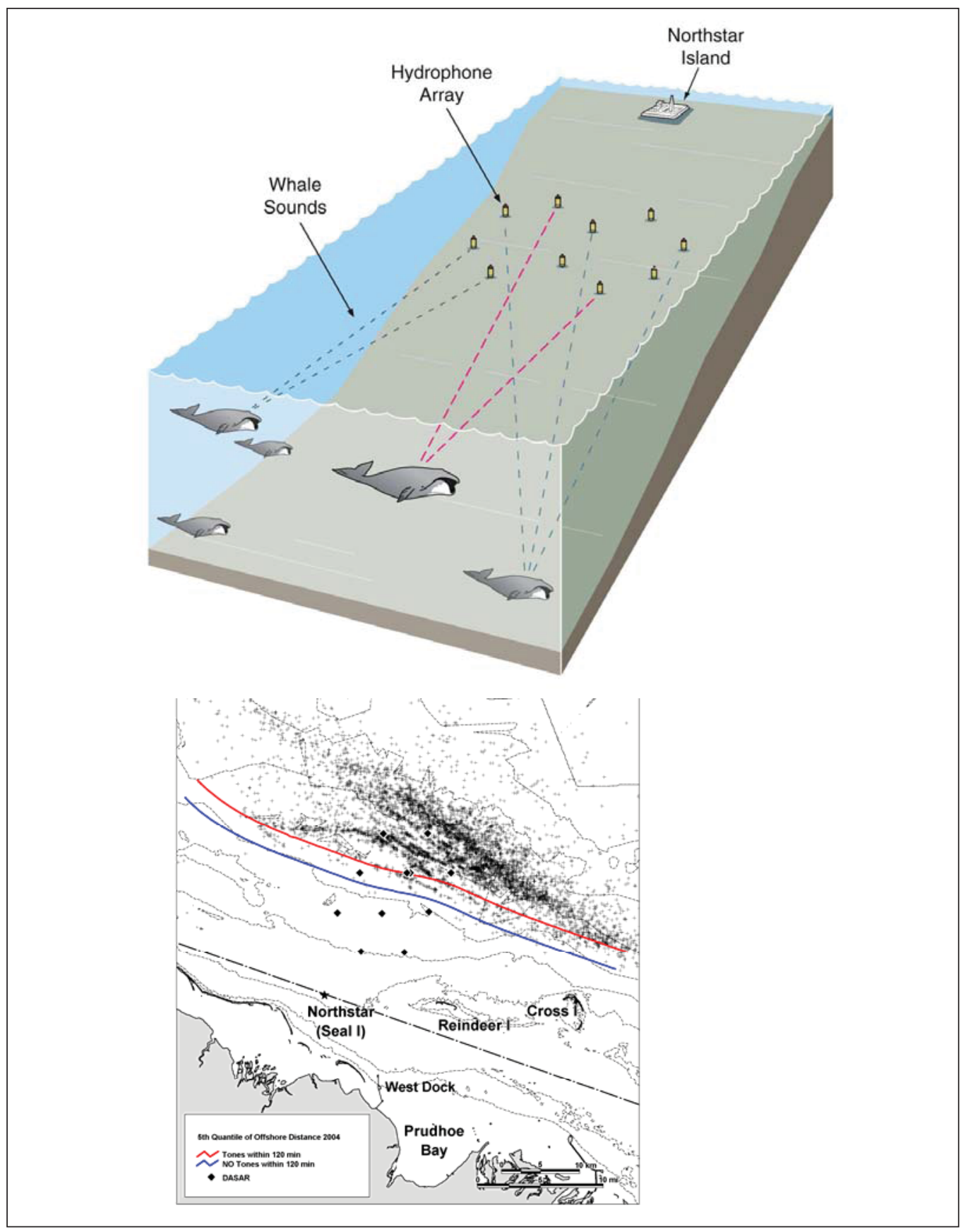

Figure D-18. Northstar whale study (Northstar is north of the STP). 

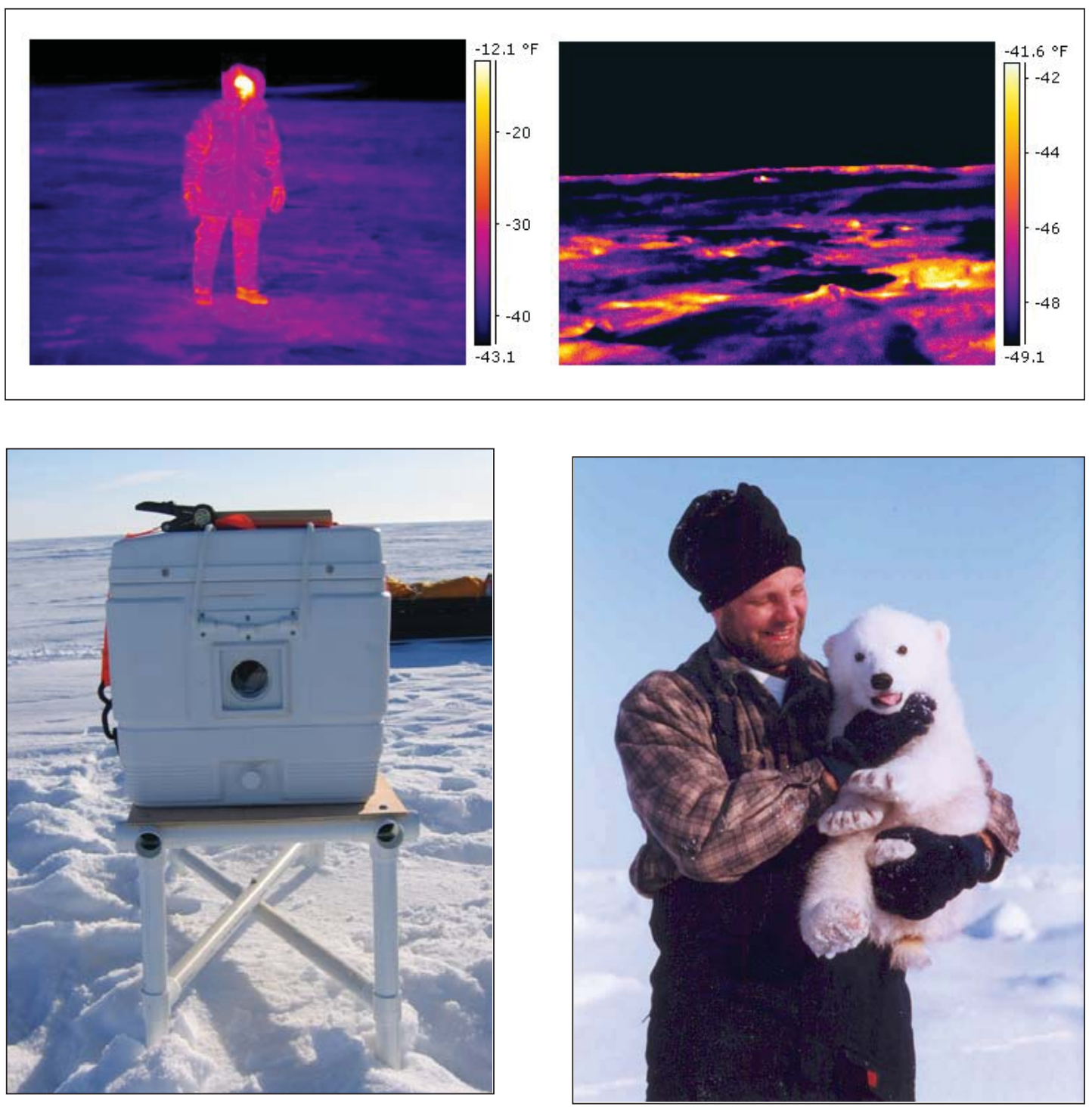

Figure D-19. Polar bear studies: FLIR, behavior, and population studies. 


\section{Prudhoe Mound Pingo}

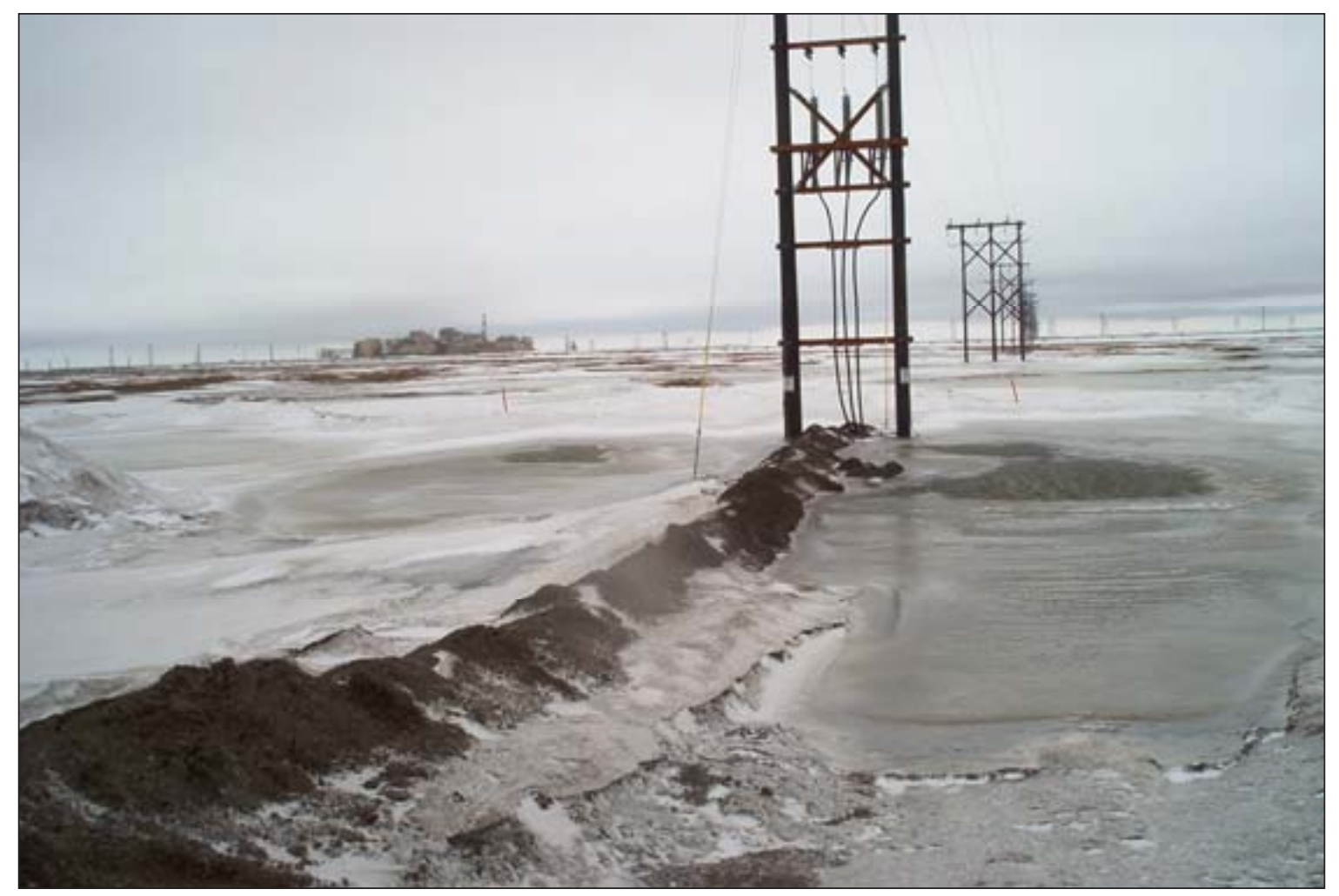

Figure D-20a. Power line trenching (near the pingo).

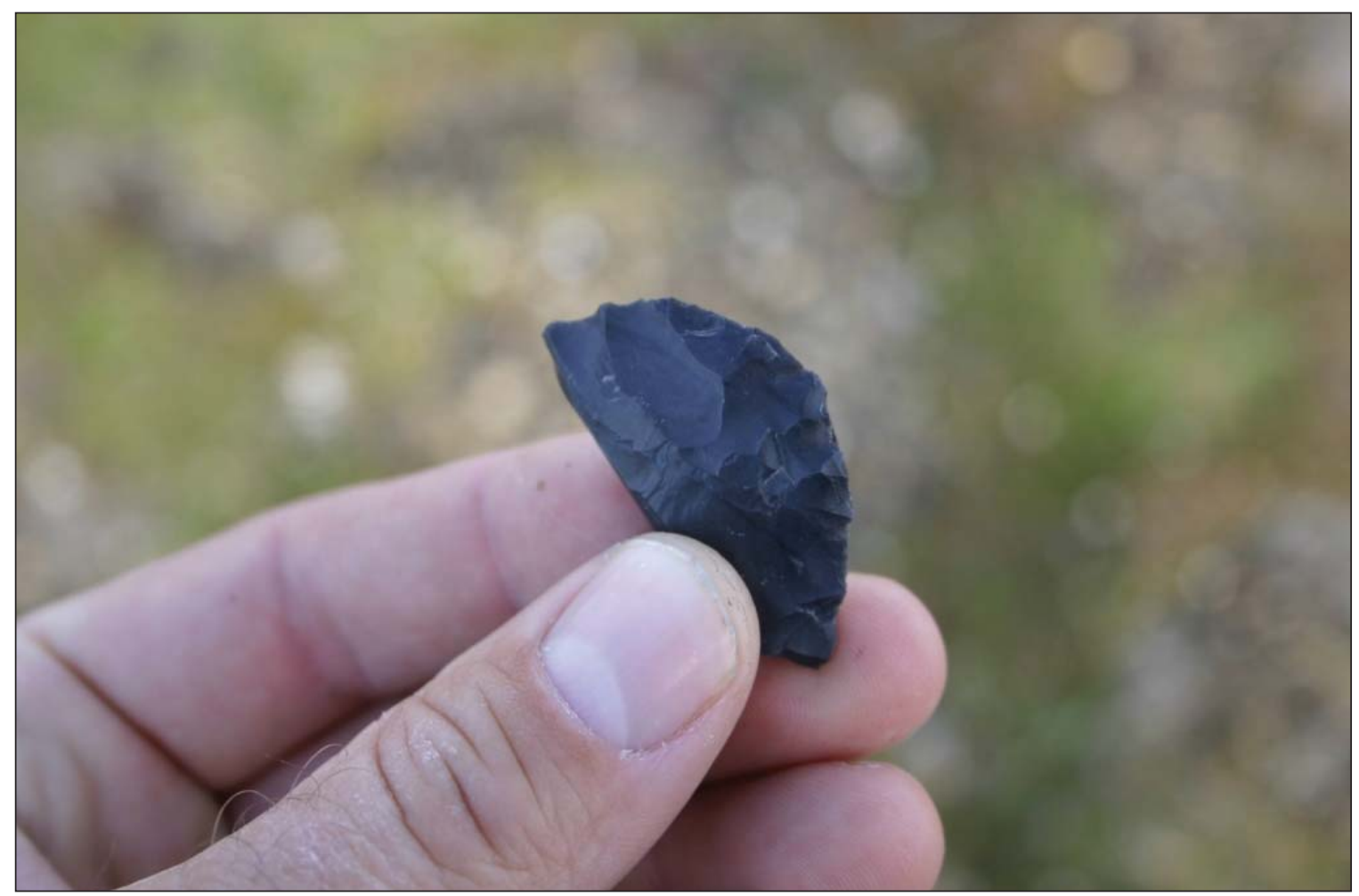

Figure D-20b. Pingos and signs of ancient habitation 

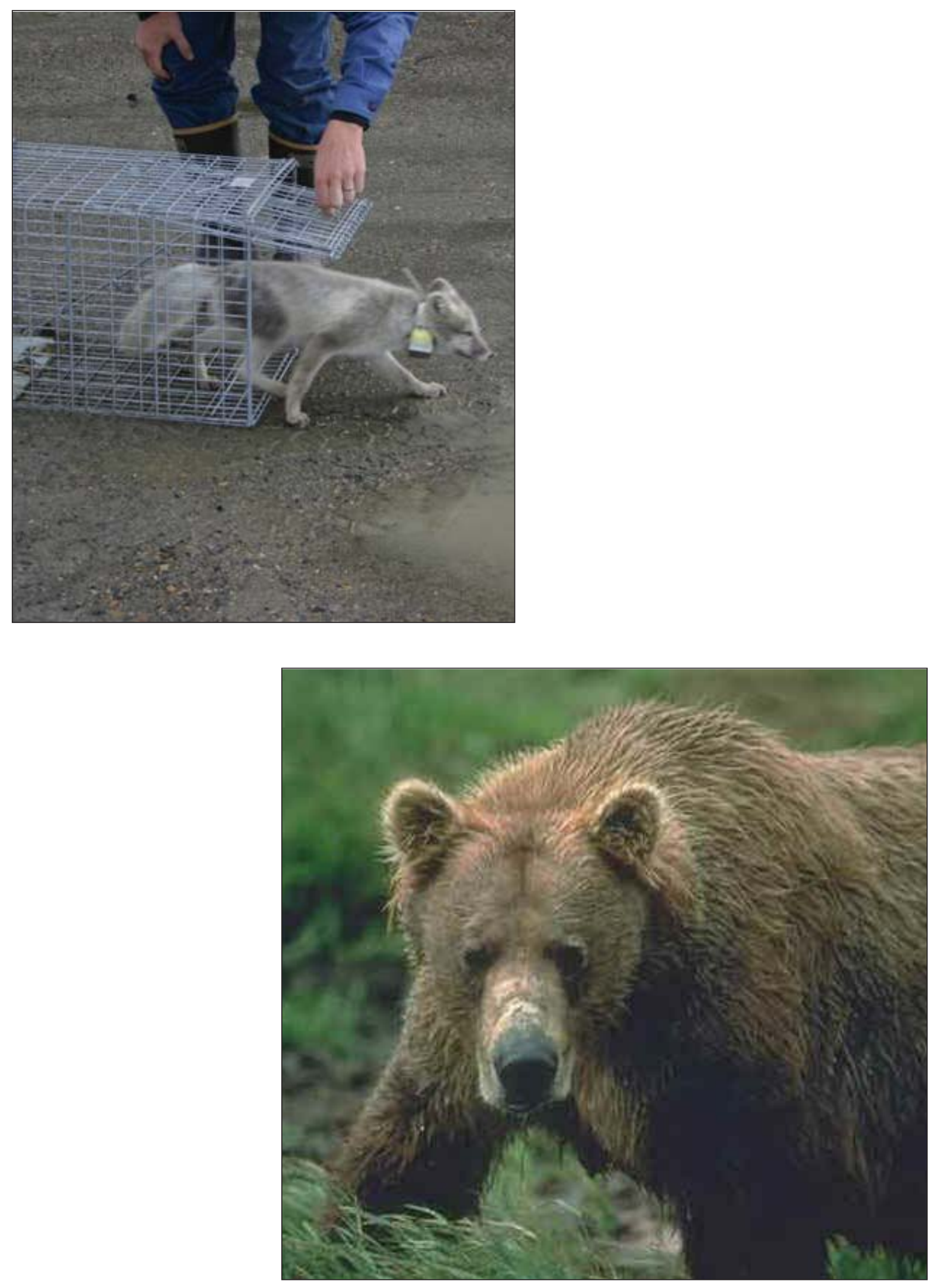

Figure D-21. Pingos and wildlife. 
APPENDIX E

\section{Permafrost temperatures along the Dalton HIghway}

\section{V.E. Romanovsky}

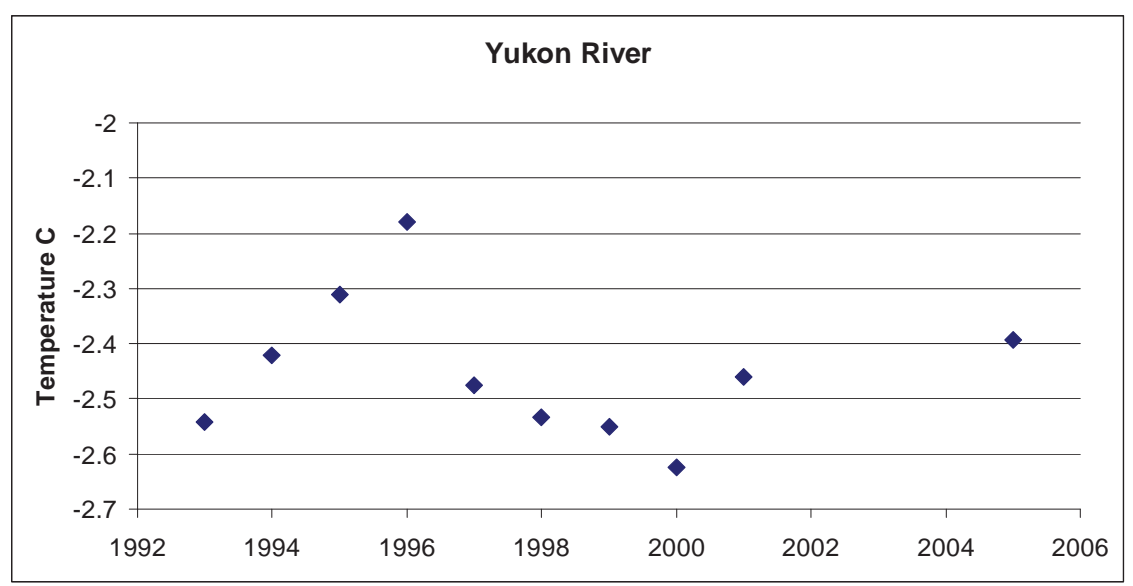

Figure E-1. Permafrost temperatures over time at the Yukon bridge site for $20 \mathrm{~m}$ depth.

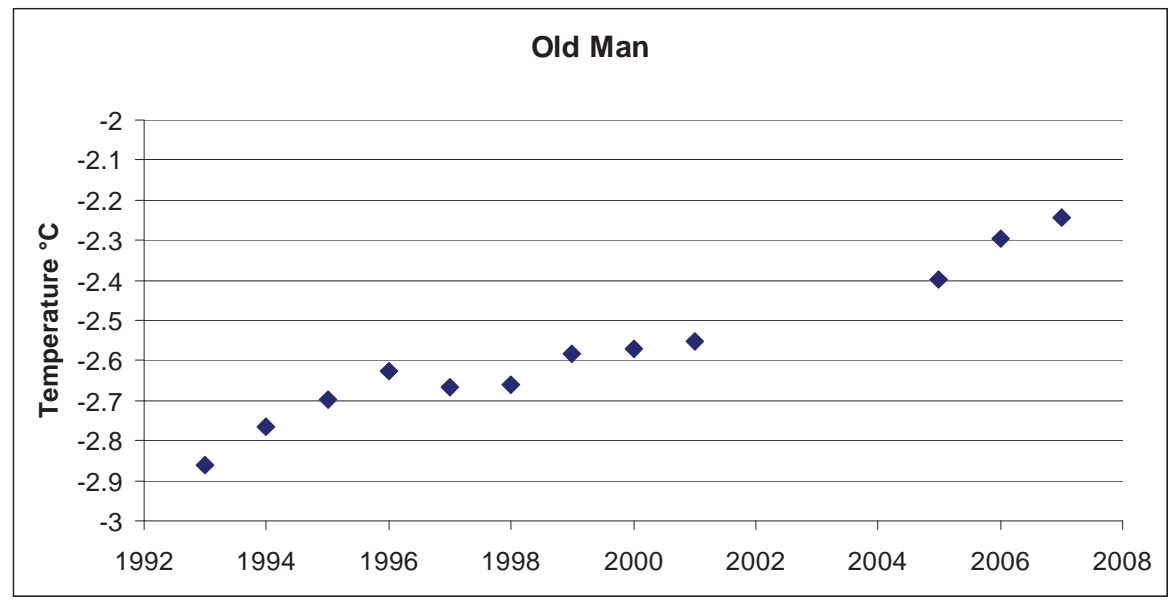

Figure E-2. Permafrost temperatures over time at the Old Man site for $20 \mathrm{~m}$ depth.

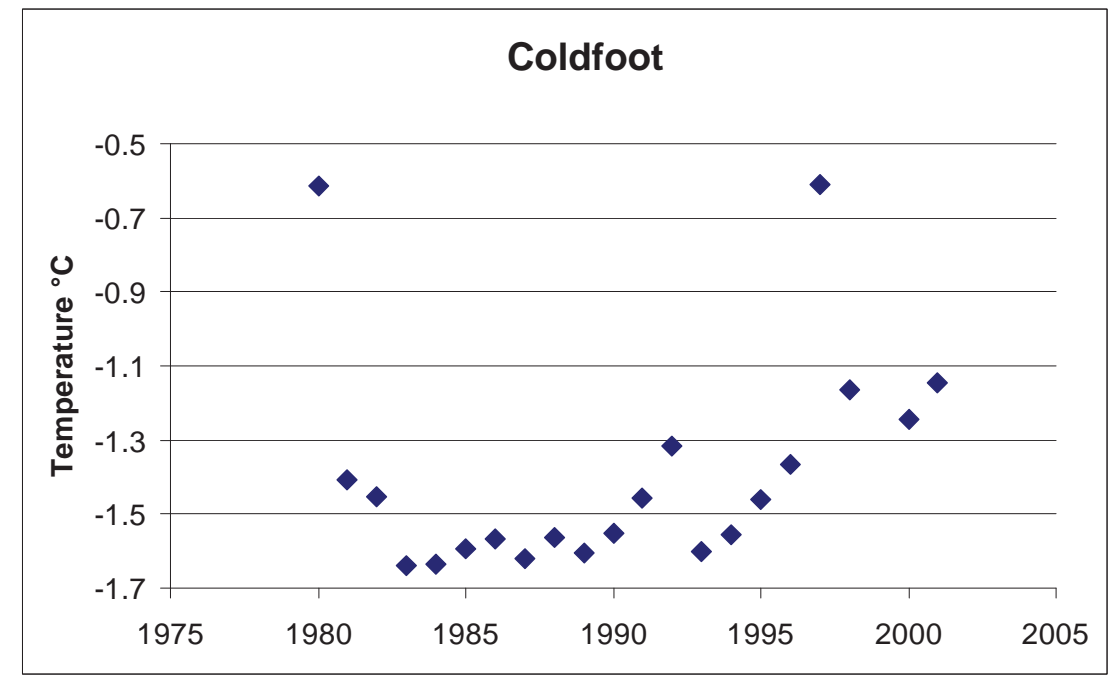

Figure E-3. Permafrost temperatures over time at the Coldfoot site for $25 \mathrm{~m}$ depth. 


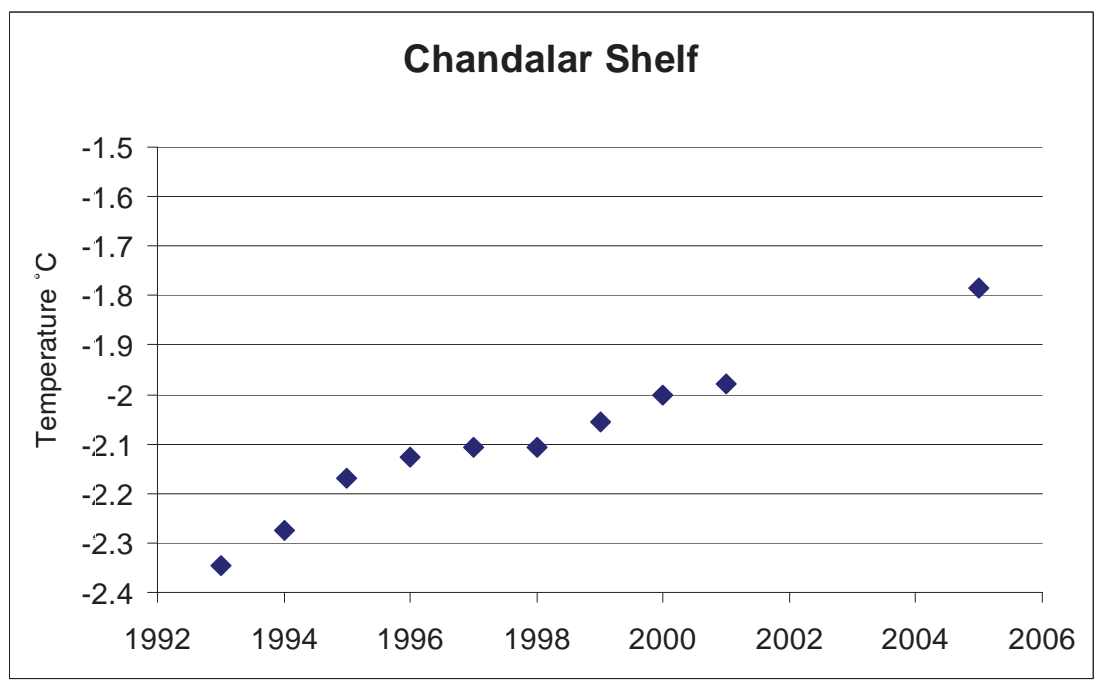

Figure E-4. Permafrost temperatures over time at the Chandalar Shelf site for $25 \mathrm{~m}$ depth.

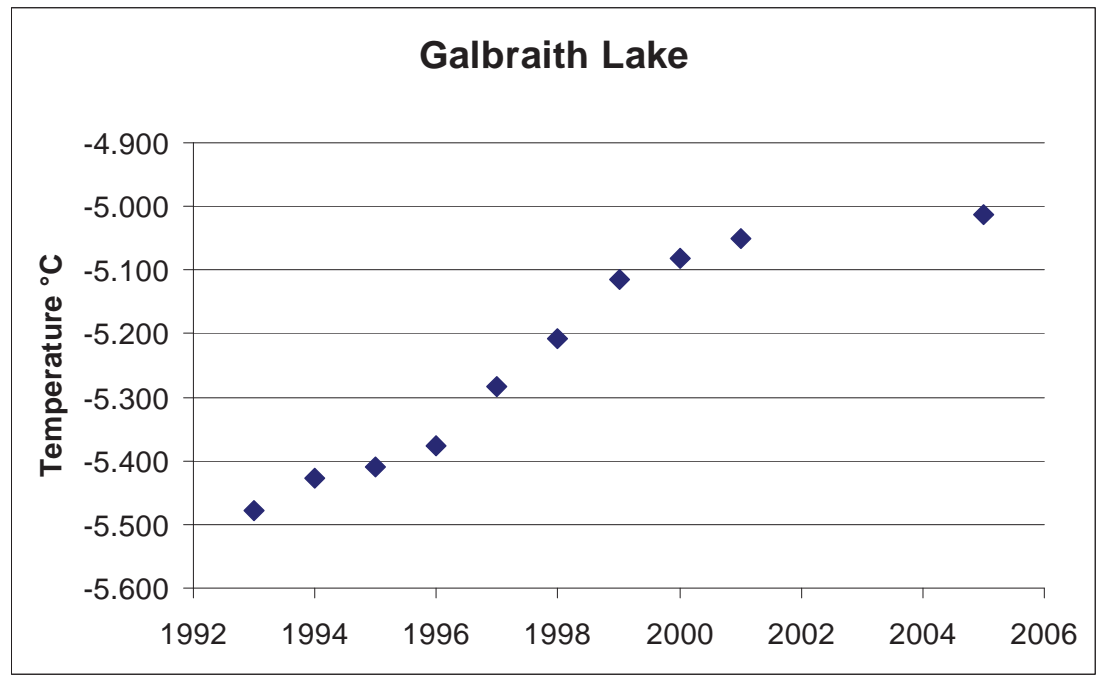

Figure E-5. Permafrost temperatures over time at the Galbraith Lake site for 25 m depth. 


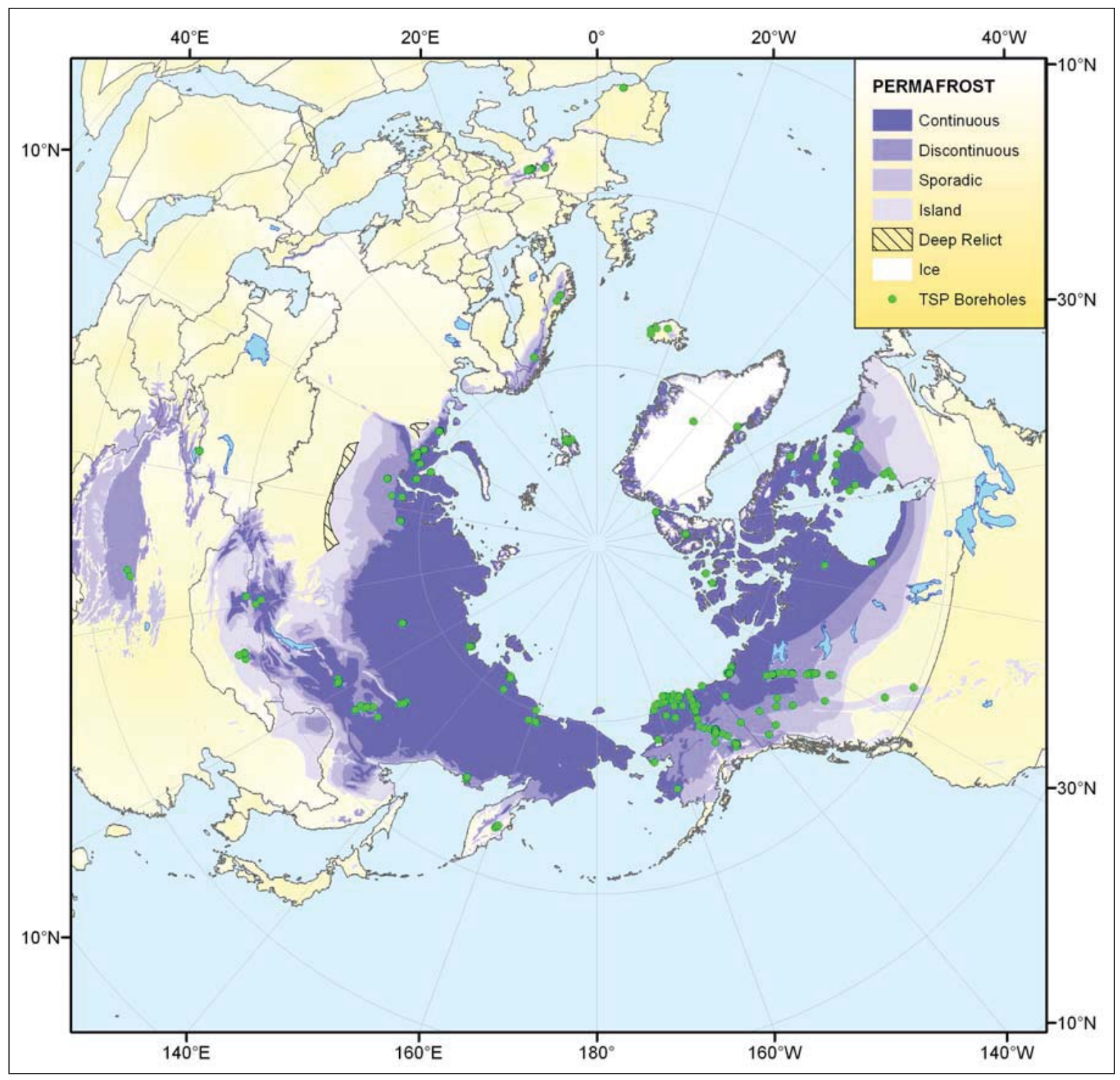

Figure E-6. Thermal state of permafrost map, showing permafrost conditions and borehole locations (Courtesy of V.E. Romanovsky and S.S. Marchenko). 


\section{APPENDIX F \\ Debris slides or rock glaciers south side of Brooks Range}

\section{R.P. Daanen}

These features (fig. E-7), in which mixed materials (coarse- and fine-grained materials) slide from mountain slopes, have been identified in the Brooks Range, Alaska, although they may occur elsewhere. They were first described by Hamilton (1978) as "Unsorted, nonstratified angular to subangular rubble in fine-grained matrix forming lobes subject to slow and probably continuous downslope motion. Common on all varieties of schist within the Chandalar Quadrangle (see Brosgé and Reiser, 1964); also are present locally on slate, limestone, and hornfels. Probably include some inactive rock glaciers.” These slides occur in frozen material rather than the better known mud slides of thawed soils.

Based on geomorphology, location, and surficial characteristics, ground ice is a key part of this feature. Similar to rock glaciers, these features move at a slow pace, and they originate from a concave region on the flank of a mountain. This movement is most likely driven by gravity with ice and water as the sliding agent. As Hamilton (1979) suggests, the key difference from a rock glacier is that these features are made up of fine-grained materials. We know that these features are common in the southern portion of the Brooks Range between Coldfoot and Atigun Pass. Many flow slides are located close to the Dalton Highway and the Trans-Alaska oil pipeline.

\section{References}

Brosgé, W.P., and Reiser, H.N., 1964, Geologic map section of the Chandalar Quadrangle, Alaska: U.S. Geological Survey Miscellaneous Geologic Investigations Map I-375, 1 plate, scale 1:250,000.

Hamilton, T.D., 1978, Surficial map of the Chandalar Quadrangle, Alaska: U.S. Geological Survey Miscellaneous Field Studies Map FF-878A, 1 plate, scale 1:250,000.

Hamilton, T.D., 1979, Surficial geologic map of the Chandler Lake Quadrangle, Alaska: U.S. Geological Survey, Miscellaneous Field Studies Map 1121.

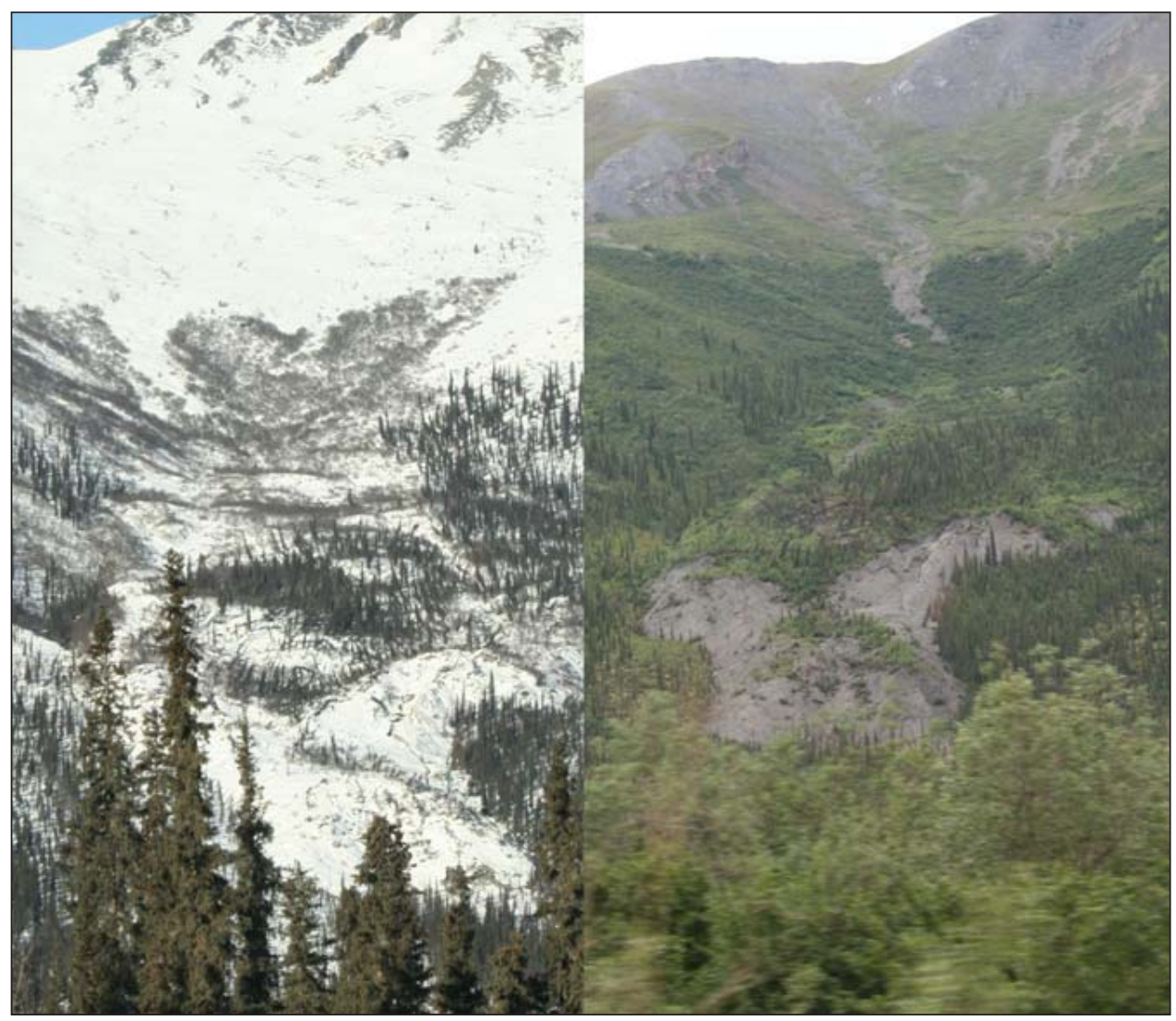

Figure E-7. View of a flow slide in winter and summer, Brooks Range (67\%51'42” $N$ and 14951'58”'W). Photos by R. Daanen. 


\title{
1. RESTIRAL RESOURCES
}

\author{
STATE OF ALASKA
}

Sarah Palin, Governor

Tom Irwin, Commissioner, Department of Natural Resources

Robert F. Swenson, State Geologist and Director 